UNIVERSIDADE DE SÃO PAULO

INSTITUTO DE PSICOLOGIA

JOSÉ JOZEFRAN BERTO FREIRE

DA DOUTRINA E DO MÉTODO EM MEDICINA LEGAL. ENSAIO EPISTEMOLÓGICO SOBRE UMA CIÊNCIA BIO-PSICO-SOCIAL 


\section{DA DOUTRINA E DO MÉTODO EM MEDICINA LEGAL. ENSAIO EPISTEMOLÓGICO SOBRE UMA CIÊNCIA BIO-PSICO-SOCIAL}

Tese apresentada ao Instituto de Psicologia da Universidade de São Paulo para obtenção do título de Doutor em Psicologia

Programa: Psicologia Social

Orientadora: Professora Titular Zélia Ramozzi-Chiarottino 
AUTORIZO A REPRODUÇÃO E DIVULGAÇÃO TOTAL OU PARCIAL DESTE TRABALHO, POR QUALQUER MEIO CONVENCIONAL OU ELETRÔNICO, PARA FINS DE ESTUDO E PESQUISA, DESDE QUE CITADA A FONTE.

Catalogação na publicação

Biblioteca Dante Moreira Leite

Instituto de Psicologia da Universidade de São Paulo

Freire, José Jozefran Berto.

Da doutrina e do método em medicina legal. Ensaio epistemológico sobre uma ciência bio-psico-social / José Jozefran Berto Freire; orientadora Zélia Ramozzi-Chiarottino. --São Paulo, 2009.

$237 \mathrm{p}$.

Tese (Doutorado - Programa de Pós-Graduação em Psicologia. Área de Concentração: Psicologia Social) - Instituto de Psicologia da Universidade de São Paulo.

1. Medicina legal 2. Epistemologia 3. Médodo dialético 4. Frequente aristotélico 5. Filosofia da ciência 6. Psicologia social I. Título. 
José Jozefran Berto freire

\section{TÍTULO: DA DOUTRINA E DO METODO EM MEDICINA LEGAL. ENSAIO EPISTEMOLOGICO SOBRE UMA CIENCIA BIO-PSICO-SOCIAL}

Tese apresentada ao Instituto de Psicologia da Universidade de São Paulo para obtenção do título de Doutor

Programa: Psicologia Social

Aprovado em:

\section{Banca Examinadora}

Prof. Dr.

Instituição: Assinatura:

Prof. Dr.

Instituição: Assinatura:

Prof. Dr.

Instituição: Assinatura:

Prof. Dr.

Instituição: Assinatura:

Prof. Dr.

Instituição: Assinatura: 


\section{DEDICATÓRIA}

À minha família com a qual, convivendo, fui me forjando.

Aos meus Mestres, partícipes essenciais de minha formação.

Aos meus amigos e àqueles que me querem bem, pelo que significa Amizade. 


\section{AGRADECIMENTOS}

À minha orientadora Zélia Ramozzi- Chiarottino, que teve como "Directeur de Thèse" Gilles Gaston Granger e que seguindo seus passos indicou-me com brilhantismo a via pela qual seguir na realização deste trabalho.

À Universidade de São Paulo, pelo privilégio de participar do ambiente de ciência que a permeia.

Ao Instituto de Psicologia da USP, pela oportunidade de conviver com seus Professores e colegas.

À Biblioteca da Faculdade de Direito da Universidade de São Paulo, pelo acesso a excepcional acervo de livros raros de Medicina Legal.

À Faculdade de Direito da FACAMP, na pessoa do coordenador do curso de Direito Alaor Caffé Alves, pela oportunidade de ali exercer o ensino da Medicina Legal.

Aos Professores de minha Banca de Qualificação do Doutorado: Professor Genival Veloso de França, pela sua disponibilidade e profundo conhecimento da Medicina Legal. Ao Professor Nelson da Silva Junior, pela generosa acolhida de minha Tese.

À Raquel Tonolli Jacob, pelas aulas de Lógica e da Filosofia de Popper.

Ao Gabriel Soares Bádue, pelas aulas de Matemática e Lógica Matemática.

Às funcionárias do Departamento de Psicologia Social do IP-USP, Nalva e Cecília, pelo gentil atendimento de sempre. 
Conceito é a unidade mental do múltiplo.

Immanuel Kant

O verdadeiro conceito implica os sistemas de classes, portanto, conjuntos de objetos, agrupados segundo relações de encaixe hierárquicas (parte e o todo), e os sistemas de relações particulares, agrupadas segundo sua natureza simétrica ou assimétrica.

Zélia Ramozzi-Chiarottino 


\section{RESUMO}

FREIRE, José Jozefran Berto. Da Doutrina e Do Método em Medicina Legal. Ensaio Epistemológico Sobre Uma Ciência Bio-Psico- Social. São Paulo, 2009, 237p. Tese de Doutorado - Instituto de Psicologia, Universidade de São Paulo.

Este ensaio inicia-se com um sucinto painel a respeito de uma pesquisa bibliográfica sobre Medicina Legal que começa com Ambroise Paré em 1532 e chega ao ano de 2008; pesquisa esta que muito nos ajudou no planejamento desta Tese. É preciso que se diga que o conceito de Medicina Legal só aparece em 1621 com Paolo Zacchia (Quaestiones Medico Legales...). Nosso objetivo neste trabalho envolve diferentes aspectos teóricos dessa ciência. O primeiro é o de demonstrar que a Medicina Legal pode ser a ciência de uma classe no sentido da Lógica e que ela não seria, portanto, a exemplo da Medicina Clínica, "uma ciência do indivíduo", como diz Gilles Granger em sua obra sobre Epistemologia já tornada célebre. O segundo aspecto teórico seria o de propor a Medicina Legal como uma ciência do "freqüente aristotélico" (hòs epì tò polú - $\omega \sigma \varepsilon \pi \imath \tau 0 \pi \mathrm{o} \lambda v$ - termo cunhado pelo helenista Porchat Pereira, enquanto conceito filosófico) graças ao qual situamos nossa ciência entre o acidental e o necessário e universal do pensamento lógico-matemático. Em terceiro lugar discorreremos sobre o fato de que os laudos médico-legais estão normalmente restritos a constatação empírica e, então, iremos demonstrar a também indispensável consideração das condições a priori da possibilidade de se estabelecer o visum et repertum, ou seja, a consideração do papel do encéfalo na leitura da experiência possível ao ser humano, numa linguagem atual. No que diz respeito à prática, realizamos uma pesquisa na qual analisamos 996 laudos médico-legais, no Brasil, cujos problemas nos remeteram à questão do Método. Sobre o Método, consideramos as teorias de Aristóteles, Descartes, Kant, Popper, Piaget e Granger, deixando de lado os grandes empiristas como Francis Bacon, David Hume, Stuart Mill, na medida em que suas teorias, devido às crenças embutidas no próprio Empirismo, não há lugar para o cérebro como condição primeira de qualquer tipo de leitura da experiência no mundo sensível. Ora, muitos biólogos, inclusive no Brasil, a partir do Prêmio Nobel em Fisiologia ou Medicina, Konrad Lorenz, consideram que o a priori kantiano pode ser interpretado hoje, como o aspecto endógeno, orgânico, da possibilidade humana de conhecer o mundo (o encéfalo) necessário a toda e qualquer leitura da experiência vivida, sobretudo quando houver a necessidade de explicá-la e reportá-la a terceiros. No caso da Medicina Legal, reportá-la à Justiça, com muitíssimas implicações psico-sociais. Nós proporemos então, à Medicina Legal, um Método Dialético, procurando demonstrar suas vantagens teóricas e práticas.

Palavras chave: 1) Medicina legal. 2) Epistemologia. 3) Método dialético. 4) freqüente aristotélico. 5) Filosofia das Ciências. 6) Psicologia Social. 


\begin{abstract}
.
FREIRE, José Jozefran Berto. Doctrine and Method in Forensic Medicine. An Epistemological Essay on a Bio-Psycho-Social Science. São Paulo, 2009, 237p. Thesis Institute of Psychology. University of São Paulo.
\end{abstract}

This essay begins with an overview of a bibliographic research on Forensic Medicine, from its early onset with Ambroise Paré, in 1532, up to the present. This research played an important role on the planning of this thesis (it is important to emphasize that the proper concept of Forensic Medicine, however, appears only in 1621 with Paolo Zacchia,Quaestiones-Medico-Legales...). Our purpose in this work includes many theoretical aspects of this science, first of all, to show that Forensic Medicine should be considered a "science of a class" in the sense of Logic, instead of, as in Clinical Medicine, "a science of the individual", as stated by Gilles Granger in his already classical work on epistemology. The second theoretical objective will be to propose Forensic Medicine as a science of the "Aristotelian frequent" (hòs epì tò polú $-\omega \sigma \in \pi \imath \tau 0 \pi \mathrm{o} \lambda v$, term coined by the Hellenist Porchat Pereira as a philosophical concept), through which such science should find its place between the realm of the mere "accidental", and that of the "necessary and universal", proper to the logic-mathematical reasoning. Thirdly, we also address the problem that the forensic reports are usually limited to empirical observations, and, then, we will also demonstrate the necessity to take into account a priori conditions of the possibility of the making of Visum et repertum, that means, we aim to consider the role of the brain in the framing of the human being's accessible experience, through a contemporary approach. On the empirical side, we conducted an extensive research, analyzing 996 Brazilian forensic reports, whose problems led us to questioning the generally used method. On the method, we discussed the theories of Aristotle, Descartes, Kant, Popper, Piaget and Granger, leaving aside the great empiricists such as Francis Bacon, David Hume, Stuart Mill, as in their theories, due to the embedded beliefs of empiricism, there is no room for the brain as the first condition of the possibility of any kind of sensory experience of the world. However, many biologists worldwide (Brazil included), since the work of Konrad Lorenz (Nobel Prize, Physiology or Medicine, 1973) has begun to circulate amid the scientific community, moved to consider that the Kantian a priori can be interpreted as the endogenous aspect (organic) of the human ability to apprehend the world, necessary to any construction of actual experience, especially when there is an intent to explain and report it to others. In the case of Forensic Medicine, it means reporting the findings to the Judicial System, which entails many psycho-social effects. Finally, we propose to Forensic Medicine a dialectical method, aiming to demonstrate its theoretical and practical advantages.

Key words: 1) Forensic Medicine. 2) Epistemology. 3) Dialectic Method. 4) "Aristotelian frequent". 5) Philosophy of Science. 6) Social Psychology. 


\section{RESUMÉ}

FREIRE, José Jozefran Berto. Sur la Doctrine et la Méthode en Médecine Légale. Un essai épistémologique sur une science biopsicossociale. Thèse de Doctorat. São Paulo, 2009, 237p., Institut de Psychologie de l' Université de São Paulo.

Cet ouvrage commence avec l'esquisse d'une recherche sur la bibliographie relative à la Médecine Legale, entre 1532 et 2008 et qui nous a beaucoup aidé dans l'ébauche de cette thèse. Il faut remarquer que ce concept n'apparaît qu'en 1621 avec Paolo Zacchia. Notre but dans ce travail a des différents aspects théoriques dont le premier est celui de démontrer que la Médecine Legale peut être la science d'une classe dans le sens de la Logique et qu'elle ne sauraît pas, à l'exemple de la Médecine Clinique, "une science de l'individu" comme a dit Gilles Granger dans son oeuvre d'épistémologie déjà célèbre. Le second aspect, serait celui de proposer la Médecine Legale comme la science du "fréquent aristotélecien" (hòs epì tò polú $\omega \sigma \varepsilon \pi \imath \tau 0 \pi \mathrm{o} \lambda v$, expression créée par l'helléniste brésilien, Porchat Pereira en tant que concept philosophique) lequel situe notre science entre l'accidentel et le nécessaire et l'universel de la pensée lógico-mathématique. Troisièmement nous parlerons de comment les avis médico-legales sont normalement, prisonniers de la constatation empirique; alors nous irons démontrer le besoin de considérer aussi les conditions a priori de la possibilité du visum et repertum, c'est à dire, le rôle de l'encéphale dans la lecture de l'expérience possible à l'être humain, dans un langage moderne. En ce qui concerne la practique, nous avons fait l'analyse de 996 avis médico-legales délivrés au Brésil, dont les problèmes nous ont remis à la Méthode. Sur la Méthode on a remonté à Aristote, Descartes, Kant, Popper, Piaget et Granger en laissant à part, les grands empiristes tels que Francis Bacon, David Hume, Stuart Mill, dans la mesure ou chez eux, justement à cause de leurs empirisme, Il n'y a pas de place pour le cerveau comme condition première de la lecture de n'importe quelle expérience dans le monde sensible. Or, beaucoup de biologistes, à partir du Prix Nobel, em Physiologie et Médecine, Konrad Lorenz, considèrent que l'a priori kantien peut être traduit aujourd'hui comme l'aspect endogène, organique, de la possibilité de connaître, chez l'être humain, (l'encéphale) nécessaire à toute lecture de l'expérience vecue, surtout quand on a besoin de l'expliquer et de la reporter à quelqu'un d'autre. Dans les cas de la Médecine Légale, la preuve à la Justice, avec ses implications psycho-sociales. Nous proposons donc, à la Médecine Legale, une Méthode Dialectique dont nous verons ses avantages théoriques et practiques.

Mots clé: 1) Médecine Legale. 2) Épistémologie. 3) Méthode Dialectique. 4) fréquent aristotélecien.

5) Philosophie des Sciences. 6) Psychologie Sociale. 


\section{SOMMARIO}

FREIRE, José Jozefran Berto. Sulla Dottrina e sul Metodo nella Medicina Legale. Un saggio Epistemologico su una scienza bio-psico-sociale. São Paulo, 2009, 237p. Tesi di Dottorato $(\mathrm{PhD})$, presso 1’Istituto di Psicologia dell`Università di São Paulo.

Questo lavoro inizia con una succinta ricerca bibliografica relativa alla Medicina Legale, a partire da Ambroise Paré ( 1532 ) e arriva sino all'anno 2008, ricerca che é stata di grande aiuto per lo sviluppo di questa tesi. Dobbiamo però precisare che il concetto di Medicina Legale compare solamente nell'anno 1621 con Paolo Zacchia. Il nostro obbiettivo in questo lavoro ha differenti aspetti teorici di questa scienza il primo dei quali è di dimostrare che la Medicina Legale puó essere la scienza di uma classe nel senso della Logica e che non sarebbe pertanto, a esempio della Medicina Clinica , "una scienza dell'individuo", come afferma Gilles Granger nella sua celebre opera sull' Epistemologia. Il secondo aspetto teorico sarebbe quello di proporre la Medicina Legale come una scienza del "frequente aristotelico" (hòs epì tò polú $-\omega \sigma \varepsilon \pi \imath \tau 0 \pi \mathrm{o} \lambda v)$ termine introdotto dallo studioso brasiliano di questioni elleniche Porchat Pereira come un concetto filosofico, grazie al quale possiamo situare la nostra scienza tra l'accidentale e il necessario e universale del pensiero logico-matematico. In terzo luogo discutiremo sul fatto che i referti medico legali sono normalmente ristretti alla constatazione empirica e pertanto andremo a dimostrare anche l'indispensabile considerazione delle condizioni a priori della possibilitá di stabilire il visum et repertum, ossia la considerazione del ruolo dell'encefalo nella interpretazione della esperienza possibile all'essere umano, per dirla in un linguaggio attuale. Per quanto concerne la pratica, abbiamo realizzato una ricerca nella quale abbiamo analizzato 996 referti medico-legali, in Brasile, i cui problemi ci portarono alla questione del Método. Con relazione al Metodo, abbiamo considerato le teorie di Aristotele, Cartesio, Kant, Popper, Piaget e Granger, lasciando da parte i grandi empiristi come Francis Bacon, David Hume, Stuart Mill, per il fatto che, nelle loro teorie, giustamente a causa del loro empirismo, non c’è spazio per l'encefalo come condizione primordiale di qualsiasi tipo di interpretazione della esperienza nel mondo sensibile. Attualmente molti biologi, anche in Brasile, cominciando dal Premio Nobel in Fisiologia e Medicina, Konrad Lorenz, considerano che l'a priori kantiano puó essere interpretato oggi come l'aspetto endogeno, organico, della possibilità umana di conoscere il mondo (l'encefalo) necessario a ogni e qualsiasi interpretazione della esperienza vissuta, soprattutto quando é necessario spiegarla e riportarla a terzi. Nel caso della Medicina Legale, riportarla agli organi di Giustizia, con moltissime implicazioni psico-sociali. Noi proporremmo pertanto, per la Medicina Legale, un Metodo Dialettico, cercando di dimostrarne i vantaggi teorici e pratici.

Parole chiave: 1) Medicina Legale, 2) Epistemologia, 3) Metodo dialettico, 4) Frequente aristotelico, 5) Filosofia della scienza, 6) Psicologia Sociale. 


\section{SUMÁRIO}

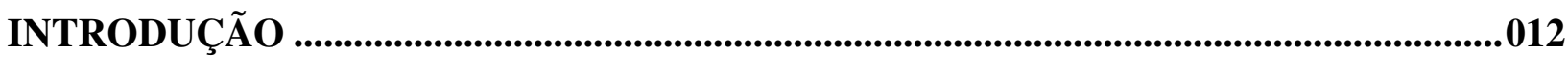

I. SUCINTO PAINEL DA BIBLIOGRAFIA PESQUISADA..................................................014

II. CONSIDERAÇÕES SOBRE A DOUTRINA ........................................................................060

A) Medicina Legal como ciência de uma classe e não como ciência do indivíduo...........069

B) A Medicina Legal entre o acidental, $o$ freqüente aristotélico (hòs epì tò polú $\omega \sigma \varepsilon \pi \imath \tau 0 \pi 0 \lambda v)$ e o necessário lógico-matemático.......................................................................072

C) Das condições a priori do visum et repertum ....................................................................098

III. PESQUISA .........................................................................................................................................151

IV. SOBRE O MÉTODO: REFLEX̃̃O E PROPOSTA........................................................174

A) A justificativa da escolha dos autores....................................................................................175

B) O Método e a Lógica de Aristóteles .......................................................................................176

C) O Método em Descartes. As regras para direção do espírito ............................................187

D) O Método em Kant: verdades de fato e verdades da Razão. Os perigos da anfibolia transcendental.............................................................................................................. 195

E) O Método dialético em Piaget. A superação das contradições na leitura da experiência e a justificativa teórica para o levantamento da "hipótese rival". $O$ duplo uso da Razão no processo da abstração reflexiva...................................................................213

F) Abertura para a proposta de um Novo Método em Medicina Legal .............................226

V. CONCLUSÕES E CONSIDERAÇÕES ......................................................................................230

VI. REFERÊNCIAS BIBLIOGRÁFICAS...............................................................................233 
Folha1 capa 


\section{INTRODUÇÃO}

Durante mais de trinta anos na prática da Medicina Legal enquanto legista, muitas foram as nossas indagações e as nossas dúvidas. Uma leitura aqui, diversas outras acolá, levaram-nos a muitas reflexões. Juntem-se a isso as inúmeras perguntas vindas de alunos nos muitos anos em que lecionamos Medicina Legal e as colocações dos colegas, em anos de convivência.

Surgiu desse conjunto de eventos, a vontade de fazer um Mestrado. Mestrado este feito na FOP/UNICAMP, sobre o tema "Estatura: dado fundamental em Antropologia Forense", onde propusemos um método estatístico adequado às populações do Brasil, para se estabelecer a estatura a partir da medida de ossos longos. Após algum tempo, pensamos num Doutorado no qual colocaríamos nossas indagações e, na medida do possível, buscaríamos algumas respostas a essas preocupações que permearam nossa vida profissional.

Assim iniciamos nosso percurso com vistas ao Doutorado no Instituto de Psicologia da Universidade de São Paulo, sob a orientação da Professora Zélia Ramozzi Chiarottino que já orientara dois outros trabalhos no âmbito da Medicina Legal. Os cursos de Filosofia da Ciência de nossa orientadora, ex-orientanda de Gilles Gaston Granger na Université d'AixMarseille na França e a bibliografia por ela indicada levaram-nos a idealizar uma Tese que partiria na realidade, de leituras ocasionais que fizéramos, durante a vida, no âmbito da 
Filosofia. Ainda na Faculdade de Medicina, lêramos, a pedido de um professor, Santo Agostinho discutindo a noção de tempo. Esse foi um dos elos que nos permitiu adentrarmos às questões filosóficas que na realidade sempre nos inquietaram.

Esta Tese, realizada em quatro anos, iniciou-se com uma pesquisa bibliográfica sobre os principais autores da Medicina Legal ao longo de seis séculos. Além da matéria dos cursos de Filosofia da Ciência, lemos e estudamos vários autores dentre os quais destacaríamos: Alexandre Lacassagne, Mathieu Joseph B. Orfila, Paul Brouardel, Giovanni Gandolfi, E. Hoffman, Flamínio Fávero, Genival Veloso de França e autores clássicos do Direito como: Jeremias Bentham, C. J. A. Mittermaier, Nicola Framarino dei Malatesta, Francois Gorphe, Erich Dörhing, Moacyr Amaral Santos, etc .

No âmbito da Filosofia da Ciência, estudamos boa parte das Filosofias de: Aristóteles, René Descartes, Immanuel Kant, Karl Popper, Jean Piaget, Manuel Garcia Morente, Gilles Gaston Granger e Oswaldo Porchat Pereira. Depois de vários esboços, estruturamos nossa Tese em quatro capítulos. O primeiro diz respeito a um painel da bibliografia pesquisada no período de 1532 a 2008. O segundo é aquele no qual se trata da Doutrina do ponto de vista da Filosofia da Ciência. O terceiro relata nossa pesquisa sobre 996 laudos realizados no Brasil. O quarto consiste em reflexões sobre o Método e nossa proposta para um novo Método em Medicina Legal. 


\section{CAPÍTULO I}

\section{SUCINTO PAINEL DA BIBLIOGRAFIA PESQUISADA (1525-2008)}

A Medicina Legal, como área do conhecimento humano, inicialmente sem essa denominação, data da antiguidade. Diversos autores desta ciência hoje fazem citações de períodos muito remotos da Historia Geral, nas diversas civilizações, períodos estes onde se encontram com certa facilidade atos e ações dos quais, pode-se dizer, foram o inicio incipiente de uma pretensa Medicina Legal. Na Idade Média, especialmente na denominada Idade Média Alta, atos e ações perpretados por médicos, sacerdotes e até por atos pontifícios criaram os primeiros rudimentos desta ciência. É bom que se ressalte o ocorrido no primeiro século da era cristã, onde figuras exponenciais como Galeno, criaram conceitos importantes para a Medicina Legal. Galeno trabalhando em condições adversas nos legou os conceitos de "infante nascido, feto nascente e feto morto", legou-nos ainda as importantes "docimásias", técnicas que nos permitem estabelecer se o feto nasceu com vida ou nasceu em óbito entre outros usos desta técnica tão simples e tão eficaz. O denominado período científico da Medicina Legal ocorre concomitantemente com o alvorecer do Renascimento. Nesta época, floresce esta ciência na Europa, produzindo-se então, conhecimento científico e o alvorecer efetivo da Medicina Legal, isto, no século XVI. Naquela ocasião, o fulcro desta ciência se restringia a produzir relatos em Juízos. Seria, a Medicina Legal, no dizer de Ambroise Paré: “A arte de fazer relatórios em Juízo". 
Fávero (1991: 26-27) apresenta um histórico, partindo do que ele denomina de "traços médico-legais", no Código de Hamurabi, e continua, referindo-se à lei mosaica, onde já se vislumbravam rudimentos do agir pericial. O autor busca ainda os referidos "traços" no Egito, na Grécia, no Direito Romano e relata as primeiras perícias médico-legais acontecidas nos séculos XIV e XV. Sua descrição destes tempos quase heróicos da Medicina Legal, onde práticas rudimentares e poucos conhecimentos predominavam, mostra, contudo, o esforço despendido por diversos autores na resolução de problemas que, embora originados no cotidiano, eram extremamente complexos, principalmente pelos parcos fundamentos científicos da época. Continua Fávero, apontando o "Edito della gran carta della Vicaria di Napoli” em 1525, como o evento inicial, ou seja, o nascedouro da Medicina Legal, da mesma forma que diversos autores clássicos como Brouardel, Orfila, Tourdes, Lacassagne, etc, também entenderam aquele evento como marco inicial desta ciência.

A maioria dos autores, ao se referir a estas épocas, cita o século XVIII e mais precisamente a Alemanha como o local onde se iniciou a Medicina Legal enquanto ciência. Para Fávero às mesmas páginas citadas acima: "No século XVIII, a Medicina Legal se instituiu como disciplina científica e, daí para cá, se aprofundou em realizações, pelas três escolas rivais, que disputam a supremacia - a francesa, sintética e original, a alemã, analítica e erudita, e a italiana reunindo às vantagens do gênio latino o amor às minudências da escola alemã".

França (2008: 3-5) comunica que "embora os fatos comprovem a participação médica em seus processos judiciais, os antigos não conheceram a Medicina Legal no sentido mais específico e mais moderno como ciência”. Faz então o autor, nas páginas acima referenciadas, um périplo desde a antiguidade clássica, iniciando pelo Rei Numa Pompílio que segundo se acredita, teria determinado o exame médico nas mortes das grávidas. Cita o papel dos imperadores Adriano e Justiniano e ainda o do médico Antístio que teria definido qual ferida havia produzido a morte de Caio Júlio Cesar. Tanto para França, como para diversos outros autores, uma melhor visão da prática pericial, ou seja, o chamamento do médico para orientar questões relativas à Medicina no âmbito das cortes judiciais, inicia-se, em 1234, com o Papa Gregório IX, através das denominadas "Decretais", cujo título era: Peritorum indicio medicorum. Cita o autor, a seguir, as figuras de Ambroise Paré, com trabalho denominado: Des Rapports et des Moyens d'Embaumer les Corps Morts, publicado 
em 1575; o tratado de Fortunato Fidelis, publicado em 1602, cujo título era: De Relatoribus Libri Quator in Quibis ea Omnia quae in Forensibus ae Publicis Causis Medici Preferre Solent Plenissime Traduntur; e da mesma época, o livro de Paolo Zacchia: Quaestiones Medico Legales; passando então a fazer uma exposição sobre a evolução da Medicina Legal, tanto na Europa, quanto nas Américas e especialmente no Brasil.

Para relatar os fundamentos nos quais se apoiaram e se apóiam os conceitos da Medicina Legal, esta Tese buscou na bibliografia clássica e moderna os elementos da Historia desta ciência, que pudessem iluminar os caminhos seguidos pela Medicina Legal, como segue.

Paolo Zacchia (Iniciada em 1621 e concluída em 1651), em nove capítulos e 731 páginas do livro Quaestiones medico-legales in quibus eae materiae medicae, quae ad legales facultates videntur pertinere, proponuntur, pertractantur, resolvuntur...Editio tertia correctior, auctiorque non solum variis passim locis verum et subjunctis, quae nunc recens prodeunt, partibus, octava et nona, apresenta o primeiro capítulo compreendendo: est de aetatibus, de partu illegitimo et vitali, de praegnantia, superfoetatione et mola, de morte causa partus, de similitudine et dissimilitudine natorum; o segundo capítulo contém: est de dementia, de venenis, in aliquot ff. de aedilitio edicto; o terceiro capítulo apresenta os seguintes temas: est de impotentia coeundi et generandi, de morborum simulatione, de peste et contagio; o quarto capítulo apresenta: est de miraculis, de virginitate et stupro; o quinto capítulo contém: de jejunio et quadragesima, de vulneribus, de membris eorumque mutilatione, de aere, aquis et locis; o sexto capítulo contém: de erroribus medicorum a lege punibilibus, de tormentis et poenis, de praecedentia inter medicum et jurisperitum; o sétimo capítulo contém: de monstris, de officiis divinis, de debito conjugali, de stygmatibus magorum; o oitavo capítulo apresenta: de irregularitate, de remediis medicis, de clausura monialium; o nono capítulo contém: habens consilia et responsa ad praedictas materias medico-legales pertinentia.

Percebe-se $a b$ initio, que desde a publicação de Paolo Zacchia, o rol de matérias da Medicina Legal a serem abordadas é complexo e amplo: os temas tratados pelo autor abordam questões do cotidiano da sociedade de então e são as seguintes: a idade, o parto ilegítimo, a gravidez, o engravidar novamente, a mola hidatiforme, causas de morte no parto, a semelhança e a dessemelhança do nascituro, a impotência coeundi e a impotência generandi, a 
simulação de doenças, a peste e o contágio, os milagres, a virgindade e o estupro, o jejum e a quaresma, as mutilações, a água, o ar, o local, o erro médico e respectivas punições, a relação médico e perito, os monstros, o ofício divino, o débito conjugal, os estigmas dos magos, a clausura monacal e ainda a responsabilidade do médico legista.

Pouco difere até os dias de hoje este rol de matérias abordadas por Zacchia, tratado como perguntas a serem respondidas em tribunal, pelos médicos legistas de então, sabendo-se de antemão, da importância da retórica e do domínio da língua latina, para que fosse possível o expressar-se perante a corte judicial. A Medicina Legal, iniciando sua presença na empiria, através desse livro, aponta para um caminho onde, desde o começo, se comportava como conhecimento médico aplicado às lides jurídicas.

Para que tenha uma sintética visão da produção intelectual ocorrida entre o Renascimento e a denominada Idade Moderna, vejam-se a seguir os trabalhos que viabilizaram a Medicina Legal no mundo ocidental, trabalhos estes relatados em ordem alfabética como ensinou Orfila em seu tempo, pois já naquela época era tal o número de publicações que se deviam fazer as referências aos autores por essa ordem, ou seja, a ordem alfabética. Alberti publica em 1725 a obra "Systema jurisprudentiae medicae; Ambroise Paré publica, em 1698, o livro "Ammanni, Irenicum, Numae Pompilii cum Hippocrate" e no mesmo ano "Praxis vulnerum lethalium". Amoreux, em1789, traz à lume "Notice des insectes reputes venimeux". Bartholinus já havia publicado em 1664, a obra "De pulmonum substantia et motu". Baumer publicava em 1778, o livro "Medicina Forensis". Barzelotti, em 1819, publicava "Medicina Legale" em dois volumes. Bauzmann publicava, em 1717, o trabalho "Wernünftiges urtheil von todtlichen wunden". Becker, em 1794, havia publicado "Paradoxum medico-légale de submersorum morte". Behrens, em 1698, publicava "Medicus Legalis". Bertin, em 1763, publicara "Consultation sur une naissance tardive". Boehmer em 1747, publicava "De legitima cadaveris occisi sectione". Bohn, em 1689, publicava "De vulnerum renunciatione". Brodie, em 1812, publicava "Further experiments on the action of poisons: Philosophical Transactions". Bruhier, em 1740, publicava "De l'incertitude des signes de la mort". Buechner, em 1747, publicava "De signis mortis prognosticis". Bulliard em 1815, publicava "Histoire des plants vénéneuses de la France". Camerarius, em 1725, publicava "De venenorum indole". Champeaux et Faissolle, em 1768, publicava "Expériences et observations sur la cause de la mort des noyés". Chaussier publicava, em 1786, 
"Consultation médico-légale sur une accusation d'infanticide". Coleman, em 1791, publicava “Dissertation sur la submersion, l'étranglement et la suffocation”. Coulon em 1819, publicava "Recherches sur l'acide hydrocyanique". Crassus, em 1812, publicava "Mortis repentinae examen”. Daniel, em 1776, publicava "Sammlung medicinischer Gutachten”. Desgranges em 1790, publicava "Mémoire sur les secours à donner aux noyés". Detharding, em 1754, publicava "De Cautione Médici circa casus infanticidiorum". Drouard, em 1802, publicava "Dissertation sur l'empoisonnement par l'oxyde de cuivre". Emmert, em 1805, publicava "Dissertatio de venenatis acidi borussici effectibus". Eschenbach, em 1746, publicava "Medicina Legalis". Esquirol, em 1823, publicava "Memoire sur la strangulation". Falret em 1822, publicava "l'Hypocondrie et du suicide". Faselii, em 1767, publicava "Elementa medicinae forensis". Favre, em 1812, publicava "De la sophistication des substances médicamenteuses". Fodéré, em 1813, publicava "Traité de médecine légale et d'hygiène publique". Fontana publicava, em 1781, "Ricerche sopra la fisica animale". Garmanus, em 1687, publicava "de Miraculus mortuorum". Geelhausen, em 1723, publicava "De pulmonibus neonatorum supernatantibus". Gendry, em 1650, publicava "Traité des rapports". Gérard, em 1803, publicava "Mémoire sur les perforations spontanées de l'estomac". Gerike em 1737, publicava "De necessaria vulnerum inspectione, post occisum hominem". Gmelin, em 1765, publicava "De materia toxicorum hominis vegatabilium". Hahnemann, em 1786, publicava "Ueber die arsenikvergiftung". Harvey, em1636, publicava "Exercitationes de generatione animalium". Hebenstreit, em 1753, publicava "Anthropologia Forensis". Henke, em 1820, publicava "Dissertations sur la médecine légale". Hoffmann, em 1736, publicava "De veneni accusatione". Kerner, em1820, publicava "Empoisonnement par les boudins fumés". Krapf, em 1766, publicava "Experimenta de ranunculosae nonnullorum venenata qualitate". Lafosse, em 1819, publicava "Encyclopédie Méthodique: presque tous les articles de médecine politique". Lair, em 1808, publicava "Essai sur les combustions humaines". Licetus, em 1669, publicava "De monstris causis natura”. Mehon, em 1811, publicava "Médecine Légale et Police médicale". Magendie, em 1809, publicava "Mémoire sur l'absorption, sur l'émétique". Mangold, em 1701, publicava "de Vulnere lethali". Marc, em 1808, publicava "Mémoire sur la submersion et sur la Docimasie pulmonaire". Meckel, em 1808, publicava "Dissertation sur la Médecine Légale". Menghin, em1768, publicava "De Incertitudine signorum vitae et mortis". Metzger, em 1805, publicava "Kurzgetasstes System der gerichtlichen arzneywissenschaft". Morgagni, em 1762, publicava "De sedibus et causis 
morborum". Nysten, em 1811, publicava "Recherches de Physiologie et de Chimie". Odier, em 1823, publicava "Leçons de Médecine Légale". Renard, em 1814, publicava "Dissertation inaugurale sur l'ouverture des corps". Russel, em 1796, publicava “An account of indian serpents". Schabel, em 1817, publicava "Dissertatio de effectibus veratri albi et hellebori nigri”. Schlegel, em 1800, publicava "Materialien für die staatsarzney wissenschaft". Schmitt em 1705, publicava "Ueber die lungen probe". Strash, em 1789, publicava "Scribonius, de sagarum natura et potestate". Sebiz, em 1630, publicava "De notis virginitatis". Sproegel, em 1753, publicava "Experimenta circa varia venena". Sprengel, em 1753, publicava "Medicina Forensis". Strecker, em 1753, publicava "de fide et legalitate medici in investiganda vulnerum lethalitate"1. Esta sintética apresentação dos séculos em que se fundamentou a Medicina Legal, onde a abordagem dos eventos do cotidiano que chegavam aos tribunais e necessitavam do concurso de quem detinha informações e conhecimentos para bem orientar os processos, ou seja, o médico legista comprova as afirmações feitas ao longo desta Tese, onde se diz da "longa tradição científica" da Medicina Legal. Veja-se a seguir os conceitos e postulados de autores clássicos desta ciência no dizerem cada um como entendiam a Medicina Legal.

Orfila, em 1823, designa pelo nome de Medicina Política a ciência que tem por objeto a aplicação dos princípios da Medicina às leis concernentes à saúde pública e à administração da Justiça. Essa ciência, ele a divide em dois ramos: a Política Médica (Medicina Legal Policial e Saúde Pública) e a Medicina Legal (atrelada à Justiça). A primeira agrega tudo que tende a preservar e conservar a Saúde Pública, a favorecer "o vigor" da população, a assegurar a existência e a liberdade dos cidadãos, ao exame do ar, das águas, dos lugares, dos alimentos, das habitações, das penitenciárias, das epidemias, etc.: tudo isso significa, de certa maneira, a Medicina Política. A Medicina Legal, voltada para a Justiça, se ocuparia das causas que seriam levadas aos tribunais e às cortes de Justiça.

Devergie, em 1837, comenta a definição de Medicina Legal feita por Mahon et Fodéré como sendo a arte de aplicar os conhecimentos e os preceitos principais e acessórios

\footnotetext{
${ }^{1}$ Agradeço sobremaneira à Biblioteca da Faculdade de Direito da Universidade de São Paulo, pela oportunidade de consultar o excepcional acervo de livros raros de Medicina Legal.
} 
das diversas ramificações da medicina à composição das leis e às diversas questões do direito, de modo a clareá-los e para que sejam interpretados adequadamente. Para Devergie (1837), a Medicina Legal não tem como objetivo esclarecer ou interpretar as questões do Direito. Comenta a definição de Prunelle, a mesma de Orfila: a Medicina Legal é o conjunto sistemático de todos os conhecimentos físicos e médicos que podem auxiliar os magistrados na aplicação e composição das leis - criticando sua falta de exatidão e justificando sua crítica ponto a ponto.

Sedillot (1855: 9) entende a Medicina Legal: "As ciências principiam por algumas observações isoladas, que o gênio reúne e fecunda, a sua desenvolução é lenta, mas sucessiva; o número dos sábios que as cultivam aumenta por que o interesse cresce em razão do progresso delas; por fim, chega uma época em que suas aplicações práticas são tão numerosas, tão necessárias que a sociedade inteira se apossa delas, e impõe-se a obrigação de conhecê-las”. Prossegue Sedillot, ao comentar os objetivos da Medicina Legal como sendo, instruir o médico das disposições legais a que ele está sujeito no exercício de sua arte; convidá-lo a estudar e a conhecer as numerosas questões sobre o que pode ser interrogado pelos magistrados, e dar-lhes os meios de resolvê-las com toda precisão e certeza compatíveis com a ciência; tal é o fim da Medicina Legal que se pode definir como a aplicação dos conhecimentos médicos a tudo que se refere às leis.

Gandolfi (1862: 5/18 e 43/44) diz que a Medicina Legal é a ciência que tem por objeto a aplicação dos princípios médicos ao Ministério da Justiça Civil, Criminal, Canônica e a análise filosófica de alguns elementos físicos, morais e sociais do homem, que servem de base e ordenamento às Instituições e reforma de algumas leis. Cita Casper que define justamente a Medicina Legal afirmando que tal ciência ensina o modo de examinar os fatos segundo as necessidades da legislação e da administração da Justiça.

Legrand Du Saulle (1864), no livro “A loucura diante dos tribunais”, diz que

(...) inimigo de toda ideologia obscura e estéril, mexendo com igual repugnância nas abstrações metafísicas e inspirações sonhadoras, mergulhado cada vez mais e mais no sentido dos estudos seriamente práticos, sempre na pesquisa das noções positivas de realidade, eu acumulava algumas anotações. Eis que senão, quando encontro a loucura diante dos tribunais e que será deferida amanhã ao exame dos magistrados dos advogados e dos médicos. (1864: 8) 
Souza (1870: 8/9) estabelece que existem, com efeito, entre a ciência do Direito e a ciência médica relações tão íntimas, laços tão estreitos que se não pode conceber como possam ser punidos certos crimes, sem iniqüidade, todas as vezes que a Medicina não vier esclarecer à Justiça com luzes que lhe são próprias. Esta verdade é principalmente incontestável na punição dos crimes contra a segurança da pessoa; aqui, diz um jurisconsulto que estudou a Medicina: nem a perícia dos juízes no processo, nem a dexteridade em extrair as mais racionáveis conjecturas dos indícios, presunções, opinião comum, testemunhas e outros elementos, nem enfim a confissão própria do acusado pode bastar a por em essência o material da criminalidade, que constitui o que se chama corpo de delito. Este só se verifica com certeza quando se prova fisicamente o delito quod physice delictum probat. É logo evidente, como disse Ferreira Borges, que os jurisprudentes sem os meios médicos não podem obter o fim a que se propõem.

Mata (1874: 15-26), numa análise critica da Medicina Legal, afirma que a mesma não tem dados, atos ou conhecimentos próprios, porquanto tudo o que forma esta especialidade são outros tantos atributos das demais ciências médicas de outras ciências auxiliares e de algumas outras que também engrandecem o entendimento humano. Considerada por esta sorte, a Medicina Legal, segundo o Autor, é uma espécie de miscelânea que se aproxima da enciclopédia e por isto se diferencia notavelmente a sua identidade das demais ciências médicas, como também da Física, da Química, da História Natural, da Botânica e ainda da Anatomia e da Fisiologia. Para ele, várias questões médico-legais se resolvem por meio de ensaios e observações que foram feitas sobre animais cuja fisiologia é mais próxima da espécie humana. A Medicina Legal, comenta Mata, naquilo que é a definição de Prunelle: "é o conjunto de conhecimentos médicos próprios para ilustrar diversas questões de Direito e dirigir os legisladores na composição das leis". Depois destas reflexões, nada mais fácil do que definir a Medicina Legal. Para o mesmo Mata: "Ela não é uma ciência verdadeiramente falando, posto que seu corpo de doutrina seja um composto de diversas questões que várias ciências lhe emprestam". Se este composto forma ciência e tem nome (assim o entende o Autor), não é outro que o da Filosofia. Prossegue o mesmo autor a recordar o que foi dito acerca dos caracteres deste ramo científico e se verá como sem fundamento na razão se empenham alguns para que a Medicina Legal seja outra coisa que uma aplicação de diversas ciências para a administração da Justiça e da legislação em certos casos. Quando nem eles mesmos, ao definir a Medicina Legal, a chamaram ciência, senão simplesmente uma soma de 
conhecimentos que significa então o que temos estabelecido; tampouco é uma Arte, como lhe chamaram vários autores, entre eles, Mahon, Foderé e Devergie. Os esforços da inteligência, os conhecimentos elevados que são reclamados para elucidação de suas questões não se adquirem com a humildade da Arte, ainda quando se acrescenta o nobre epíteto de liberal e tenha a sua parte prática. Tudo que não se chame "conjunto de conhecimentos" à Medicina Legal é não expressar com exatidão o caráter e a essência deste corpo de doutrina.

Segundo Dambre (1878), a Medicina Legal é a expressão das relações que as ciências médicas e naturais podem ter com a Justiça e a legislação. O autor cita como referencial as definições dadas por Orfila, onde ele reúne conhecimentos médicos propícios ao esclarecimento de questões do Direito e ainda a orientar o legislador na composição das leis. Cita também Divergie, Briand e Bayard que repetem o entendimento de Orfila ao relacionar questões do Direito, das leis e conhecimentos médicos.

Lacassagne (1878), tendo como referência central a Medicina, diz que a mesma não se ocupa somente do estudo da doença e seu tratamento, ela é mais útil colocando seus conhecimentos específicos ao serviço da organização e do funcionamento do corpo social. É assim que legisladores, magistrados, administradores públicos, etc. fazem apelo às suas luzes ou se inspiram em seus conselhos para elaborar ou aplicar leis, para cuidar e manter a saúde pública. Este papel social, essas numerosas relações da Medicina com as diferentes legislações constituem, no entendimento do autor, o que ele denomina de Medicina Política, a qual é preciso exclusivamente reservar o nome de Medicina Legal. Ela concorre assim, com a saúde pública e com a Justiça, que são as duas mais altas expressões da ordem material e moral. Observam-se aí dois escopos bem diversos: de um lado, a higiene social e a política médica e, de outro, a Medicina Judiciária. Este caráter distintivo encontra-se claramente indicado na origem da marcha e dos progressos das ciências. Lacassagne (1880: 27) cria aforismas e considerações sobre a postura científica e social da Medicina Legal. Os aforismas são quatro: 1. É preciso aprender a duvidar; 2. Os casos aparentemente mais simples podem ser os mais complicados; 3. Observar com atenção e aquilo que se observa vê-lo bem; 4. Evitar as teorias apressadas e duvidar dos desvios da imaginação. Para Lacassagne, era importante seguir-se o lema latino et vigil et prudens, porque isto se aplica à Medicina Legal de todos os tempos e de todos os países. É a fórmula que nos dá o espírito e o método dos grandes médicos legistas, como Ambroise Paré, Paolo Zacchia, Orfila, Turdes e outros. A 
vantagem da prática médico-legal é não criar um conceito exclusivo e estreitamente especializado, mas aberto a novos conhecimentos e métodos ou abordagens da prática pericial. Três coisas, diz Lacassagne, são necessárias ao Médico Legista: a profissão, a ciência e a arte. A profissão se aprende com a paciência e com o trabalho; a ciência se adquire com o estudo, mas a arte deriva das qualidades naturais instintivas. Aqueles que a possuem não são muitos.

Hofmann (1884), ao abordar o objeto da Medicina Legal, diz que esta ciência tem por objeto de estudo as questões que se apresentam no exercício da jurisprudência civil ou criminal e cuja solução aparece exclusivamente de determinados conhecimentos médicos dados de antemão. Ele partia do entendimento de que um grande número de causas, tanto no processo civil quanto no processo penal, exigem conhecimentos médicos para solução de algumas questões, por exemplo, quando se trata da determinação de certos fatos, ou da relação entre os fatos e ainda da constatação e do esclarecimento de determinadas circunstâncias importantes para a decisão do julgador em casos particulares. Para melhor esclarecer, observem-se casos onde prejuízos causados à saúde ou à vida tornam-se objeto de instrução judiciária, como aqueles que se referem aos estados fisiológicos, sobretudo os que concernem ao sexo. A intervenção dos legistas, para o autor, ocorre pelos mesmos motivos que ocorre a intervenção de outros peritos de outras áreas.

Brito (1883) entende que a Medicina Legal tem o papel especial de auxiliar a Justiça. Porém, ela não se afasta do que ele denomina "seio materno da ciência médica", pois é da Medicina que vêm todos os elementos que a constituem, tendo, portanto, um caráter médico.

Tourdes (1896) afirma que a Medicina Legal é um ramo bem distinto das ciências médicas, com características que lhe são próprias, especiais e um fim particular. Para se ter uma visão de conjunto deste estudo, e poder identificar suas linhas mais importantes, é prudente defini-la claramente e distingui-la das ciências com as quais ela foi, por longo tempo, confundida. As divisões, o histórico, o ensino, a organização e a prática dessa aplicação das ciências médicas completarão as noções gerais da Medicina Legal e, ao mesmo tempo, tornarão possível seu desenvolvimento e demonstrarão sua importância. As ciências médicas, na ótica de Tourdes, têm duas ordens de aplicações: uma individual, que é a prática médica e a outra que é social, envolvendo interesses complexos e gerais dados e fortificados pela lei, e se impondo às populações, com o rigor desta lei: é a Medicina Pública. Esta 
aplicação social, quando se ocupa da saúde pública, tem o nome de Higiene Pública. Quando tem por finalidade a manutenção do liame social, quando trata dos direitos e deveres dos indivíduos reunidos em sociedades, ela constitui a Medicina Legal propriamente dita, cujo fim é pois a solução de todas as questões médicas que dizem respeito aos direitos e deveres dos homens, quando reunidos em sociedade.

Brouardel (1897) afirma que a Medicina Legal é a aplicação dos conhecimentos das ciências médicas aos casos que interessam à Justiça e estabelece o autor ainda como deve se conduzir o perito médico-legal que não deve formular opiniões e usar expressões como "é provável", "é possível que tal ato tenha sido cometido", etc., pois à Justiça, o que interessa é uma demonstração científica dos eventos e não meras opiniões. E quando o perito não tem elementos para definir que determinado crime foi executado, deve responder o perito que "não foi possível demonstrá-lo e, portanto, prová-lo".

Bergeron (1898), ao se referir à Medicina Legal, trata-a como jurisprudência médica, que resolveria questões profissionais no território da Ética Médica e questões diversas como as lesões sofridas pelo ser humano, produzidas por agentes externos e ainda casos de interesse social, como castração, determinação da idade, suicídio, distúrbio da sexualidade, tendo como fundamento técnico os conhecimentos da Medicina clínica.

Souza Lima (1904) diz que a importância da Medicina Legal resulta da mesma gravidade dos interesses que lhe são confiados. Não seria exagero dizer que a honra, a liberdade e até a vida dos cidadãos podem depender de suas decisões. Entende que são delicadas em sua apreciação e graves, em suas conseqüências, as questões relativas à legitimidade dos nascimentos, à avaliação das testemunhas, à prova médica nas questões como infanticídio, aborto, estupro, etc. E ainda sempre foi muito influente a presença dos legistas nos casos das lesões corporais e envenenamentos, etc. Para Souza Lima, a Medicina Legal ainda engloba outras matérias como a farmacologia e a higiene. Não teria, portanto, fundamento próprio: seria uma ciência aplicada, cuja importância, porém, se impõe pela especialidade do fim a que se destina como pela complexidade dos meios que usa, pela extensão dos conhecimentos que exige e pela construção dos meios para alcançar aquele fím. Souza Lima não quer discutir a questão de que a Medicina Legal é arte ou ciência, diferentemente de outros autores. O que lhe interessa é oferecer constantemente corpo de doutrina científica sobre o qual se exercita o raciocínio do perito. Por outro lado, oferece uma 
feição artística no que respeita ao modus faciende dos exames e diligências médico-legais, bem como na redação dos respectivos relatórios. Vemos em Souza Lima muitos pontos em comum com os objetivos dessa Tese.

Nina Rodrigues (1905) entende que o médico legista não tem a idéia exata dos princípios jurídicos que obedecem às disposições dos códigos penais relativos a diversos tipos de crime e por isso tem dificuldade de compreender o elo entre a Medicina e o Direito e do papel de auxiliar da Justiça Pública que lhe é confiado pelo Estado. Entende que o médico clínico, embora possa ser notável pelo seu saber, não tem competência para esclarecer criteriosamente a relação da prática forense com a prática médica. A Medicina Legal seria ciência aplicada, fundamentada na medicina e no Direito, estabelecendo as causas e com causas dos fenômenos que ela estuda.

Peixoto (1918) diz que a Medicina Legal é uma aplicação de conhecimentos científicos aos misteres da Justiça. Não é uma ciência autônoma, no sentido exato da expressão, segundo o autor, mas um conjunto de aquisições de várias origens para um fim determinado. Se aquilo que lhe atribui como próprio fica restrito, aumenta-se-lhe o leque de possibilidades, buscando em disciplinas diversas o que seria aplicável naquele momento. Ele também entende que a formação do perito não é menos necessária do que a do médico clínico, pois o Médico legista, além dos conhecimentos médicos, deve conhecer o Direito e as Ciências Físicas e Naturais, as Ciências Sociais para o bom desempenho de sua atividade.

Sánchez (1924) propõe que a missão principal do Médico Legista é ilustrar e aconselhar a administração da Justiça toda vez que em virtude de suas demonstrações e eficácia dos seus conceitos, o juiz aprecia os significados verdadeiros de certos fatos não compreendidos por ele por serem fora de sua competência, delegando parte de sua autoridade, portanto, ao médico. A magnitude das funções do perito e a grave responsabilidade das mesmas assustam a consciência do perito, exigindo do mesmo, singular competência e especial e esmerada preparação. Os conhecimentos da Medicina Legal legaram à legislação moderna soluções para problemas controvertidos, como suavizar o rigor das leis antigas e aperfeiçor conhecimentos que alteram legislações que tratam da saúde, da vida, etc. Para Sánchez, a Medicina Legal extrai quase todos os seus conhecimentos de outras disciplinas médicas; não é autônoma pois não se nutre a si mesma. As fontes tributárias mais importantes da Medicina Legal, além da Medicina, são a Química, a Fisiologia, a Toxicologia, a 
Criminologia, a Climatologia, além da Física e de outras ciências modernas. Um caráter distintivo da Medicina Legal é seu método próprio que não deriva da maneira como o médico está acostumado a pensar. Seu caráter de assessora da Justiça para elucidar fatos delituosos lhe confere papel social importante quanto às suas decisões.

Rojas (1936) define a Medicina Legal como a aplicação dos conhecimentos médicos aos problemas judiciais, ultrapassando, desta forma, os limites da própria Medicina, dilatando sua área científica com diversos problemas sociais que requerem seu concurso. Considera ainda que a extensão (como expressão da substância extensa do cogitatio cartesiano, conclusão nossa) aos fenômenos sociais como território da Medicina Legal, tornou-a Medicina Pública, Política e Social. Tal posição choca-se com a visão clássica da Medicina Legal, na qual esta compreende unicamente o estudo dos problemas médicos relacionados à Justiça, assim configurada nas definições propostas por Orfila, Hofmann, Devergie, Taylor e outros. Devido a estas definições clássicas, alguns autores denominam a Medicina Legal de Medicina Judicial ou Forense (como até hoje na Faculdade de Direito da USP). Rojas continua, explicando que a Medicina Legal significou estritamente o estudo de questões médicas previstas ou relacionadas com as leis. Porém o termo Medicina Legal, no sentido estrito de Judicial ou Forense é aquele mais aceito nos diversos países, à sua época. Esta acepção da Medicina Legal restrita, para Rojas, deixa fora de sua área de ação a Saúde Pública e a chamada Medicina Social. É, pois, esta ciência, uma ponte que une a Medicina com o Direito e leva as luzes dos conhecimentos médicos às necessidades jurídicas tanto na sua aplicação, quanto na elaboração das leis. O estudo da Medicina Legal, para Rojas, interessaria aos médicos e aos advogados. O médico legista cultiva uma "especialidade" que não deveria ser ignorada pelos juristas, especialmente pelos magistrados. Se as leis e os códigos de processos concedem aos magistrados o direito de julgar os relatos médicos aceitando ou não suas conclusões, isso implicaria a necessidade de uma formação médicolegal prévia para estes julgadores, como forma de melhor ordenar o processo. Outro tópico importante é o pouco caso com a disciplina Medicina Legal por parte dos estudantes de Medicina que estão, em sua maioria, interessados na Medicina Clínica e não atribuem maior importância aos aspectos médico-legais do exercício da mesma. Quanto aos estudantes de Direito, a maioria deles entende que haveria poucas ocasiões para se aplicar os conhecimentos da Medicina Legal. Em ambas as situações, geram-se grandes equívocos. Quantos alunos, após tornarem-se profissionais, continuam a consultar o professor sobre pequenas questões 
médico-legais. Outra situação, ainda segundo Rojas, é importante ser analisada, aquela onde se diz que basta ser um bom médico para ser legista. Crasso e perigoso erro, que só se explica para justificar imprudência e improvisação. A Medicina Legal requer conhecimentos específicos pois tem assuntos exclusivamente seus, tais como infanticídio, identidade, jurisprudência médica, etc. Requer ainda muitos conhecimentos legais e jurídicos que a maioria dos médicos ignora ou compreende mal. Ela exige também hábitos mentais próprios, alheios à Medicina Clínica, conhecimentos esses possíveis através da reflexão e da observação dos problemas próprios dessa matéria.

Lopez (1953) diz que a Medicina Legal não é uma ciência puramente teórica, pois deve se associar à teoria um ensino prático que permita ao Médico Legista responder às questões reclamadas pela Justiça. As noções práticas são cada vez mais importantes, pois a culpabilidade de alguém não pode ser estabelecida sem um informação judicial cuja finalidade é a investigação da verdade, determinando assim o fato judicial e a identidade de seu autor. Para ele, a psicologia moderna demonstrou que o testemunho jamais foi uma prova absolutamente certa. Não porque os testemunhos careçam de sinceridade, mas porque é muito raro que a testemunha tenha visto com objetividade o evento.

Ponsold (1955) remete-se à prática médico-legal numa ótica especialmente jurídica, tendo como base o Direito Penal. A Medicina Legal seria ciência aplicada dos conhecimentos médicos nos eventos que produzem lesões no corpo humano, tema este tratado essencialmente no Direito Penal.

Calabuig (1958), por sua vez, apresenta a Medicina Legal como o elo mais direto entre a Medicina e o Direito, devendo o médico legista conhecer as realidades jurídicas, saber o que o jurista requer deles, no desenvolvimento de suas funções, dando, assim, sentido jurídico à Medicina que por isso consegue individualidade como ciência própria à Medicina Legal, que não depende só da posse de conhecimentos médicos, por profundos que sejam, nem de um domínio absoluto do Direito isoladamente, mas sim de uma integração de ambos em sentido utilitário forense, repensando juridicamente os fatos biológicos e médicos que contribuiriam para a aproximação de ambas as ciências e individualmente para cada médico legista, cumprir melhor sua missão de assessorar os tribunais na administração da Justiça na ordem civil, criminal e trabalhista. 
Para Simonin (1962), a Medicina Legal evitaria juízos obscuros, condenações abusivas e diminuiria os erros judiciais, pois o juiz, técnico do Direito, precisa ser informado por pessoa que estude os fenômenos biológicos e patológicos que atingem o ser humano e que são objeto de processo jurídico. O essencial da Medicina Legal é a construção da prova. Para alcançar este objetivo, o legista teria quatro métodos: observação, reflexão, experimentação e síntese. Os três primeiros formariam a fase objetiva e analítica do trabalho médico-legal e serviriam para reunir, justapor e controlar os elementos e circunstâncias do fato judicial. Segue-se então a fase de discussão e interpretação que corresponde a um trabalho de síntese, apoiado em conhecimentos de natureza muito diversa: médicos, físico-químicos, psicológicos, sociais, jurídicos. Todos os dados obtidos seriam confrontados e comentados com objetivo de descobrir, dentro da confusão complexa e desordenada dos fatos que os une.

Achaval (1962), em seu livro "Manual de Medicina Legal", afirma que os fundamentos da Medicina só permitem perceber que no drama da doença intervêm três elementos ou fatores: o médico, o doente e a doença. Porém o desenvolvimento social da Medicina fez com que ela perdesse seu caráter de arte de curar como definição e adquirisse outros objetivos como a investigação de eventos criminais, de Saúde Pública e político-social. Por este viés, a saúde não seria ausência de doença ou de invalidez, mas o estado completo de bem estar físico, mental, social e espiritual. Amparada entre as especialidades médicas, a Medicina Legal moderna prepara o médico para uma medicina compreensiva sob o aspecto social, influindo decisivamente no âmbito sócio-jurídico. A Medicina Legal abrange conhecimentos variados, adequados à sua aplicação e importância. Alguns desses conhecimentos são para ele de tal transcendência que se constituem ciência à parte que necessitaria de maior dedicação e especialização à medida que seus procedimentos são requisitados, que seus métodos são especializados e que suas investigações tragam reais benefícios à prática processual. Achaval propõe como ramos da Medicina Legal, a Odontologia Legal, Química Legal, Deontologia, Jurisprudência Médica, Tanatologia, Asfixiologia, Polícia Científica ou Criminalística, Identificação, Sexologia Legal, Obstetrícia Médico-Legal, Traumatologia Médico-Legal, Criminologia, Psiquiatria Forense, Medicina Legal do Trabalho e Medicina Legal do Seguro.

Piédelièvre (1963) mostra que os vastos, complexos e difíceis problemas médicos necessitam de diversos ramos do conhecimento humano para a consecução de seus objetivos. 
É obrigatório que os peritos, os magistrados, os advogados conheçam os princípios e as técnicas da Medicina Legal como forma de se resolver os problemas mais graves na administração da Justiça. O autor divide a Medicina Legal em:

1. Medicina Legal Civil, onde o perito avalia as seqüelas das doenças, as modificações resultantes de um acidente, o dano estético de uma cicatriz visível sobre a face de uma jovem mulher, por exemplo.

2. Medicina Legal psiquiátrica, que é ramo separado da psiquiatria clínica, onde o trabalho do perito é particularmente delicado, pois de sua decisão pode se considerar uma pessoa como doente mental ou em estado de demência, no momento do ato criminal, portanto inimputável. $\mathrm{Ou}$, ao contrário, quando o perito estabelece a normalidade mental do acusado, no momento do ato criminal.

3. Medicina Legal Social, que estuda o exercício da profissão médica, suas regras, seus direitos e obrigações, procurando compreender da aplicação das leis da assistência e previdência social, certos casos de profilaxia de acidentes ou de doenças do trabalho.

4. Medicina Legal propriamente dita, que trata da aplicação dos conhecimentos médicos na aplicação da Justiça.

Simas Alves (1965) nos diz que não é fácil formular uma definição de Medicina Legal, assim como também é tarefa complexa determinar objetivos e limites de uma disciplina (o autor chama a Medicina Legal de disciplina médica) que se apóia em bases doutrinárias, médicas, legislativas e sociológicas contingentes e mutáveis. Continua dizendo que, desde o Século XIX, com Brouardel e Lacassagne, a Medicina Legal fez um grande progresso tecnológico e concomitantemente, a idéia de Justiça não se limita mais ao Direito Penal, ou ao Direito Civil, pois foi criado um Direito Social que, paralelamente gerou uma Justiça Social que requer o concurso da Medicina Legal para a consecução de seus objetivos. Para o autor, o médico legista moderno pertence a uma espécie de "magistratura médicosocial", pois cotidianamente ele se transforma em árbitro: seus laudos, seus relatórios, seus atestados e seus diagnósticos são verdadeiros veredictos que esclarecem fatos tanto nos tribunais, como nas instituições securitárias, permitindo a aplicação equitativa da Justiça. Fica então evidente que se requer do médico legista além de cultura médica, uma cultura jurídica e social aprimorada. Seria então a Medicina Legal a aplicação dos conhecimentos biológicos e 
médico-cirúrgicos às questões jurídicas e sociais, a cuja resolução se tornam necessários os pronunciamentos da Medicina.

Bonnet (1967) divide a atividade do médico perito em: 1. Médicos de tribunais ou forenses, cujas obrigações são a de praticar exames, experimentos e análises a respeito de pessoas, coisas ou lugares, assistir a qualquer diligência ou ato judicial, produzir informes periciais. As tarefas dos médicos legistas são múltiplas e complexas, pois avaliam o estado das faculdades mentais, as lesões corporais, a imputabilidade, a periculosidade, o diagnóstico da idade aparente, delitos contra a honestidade, agressões a menores, acidentes de trabalho e ainda realizam as autópsias médico-legais, etc.2. Médicos de Polícia, cujas funções são as seguintes: exame das pessoas que sofreram lesões corporais, exames de cadáver em geral, exame de indivíduos de um ou outro sexo que tenham sido vítimas de delito contra a honestidade e também exame dos imputados como autores, exame do estado mental dos imputados, ou das vítimas de delitos, exame de menores que não tenham comprido 10 anos de idade e de pessoas enfermas abandonadas por seus parentes ou cuidadores, exame destinado a comprovar a aptidão física para o trabalho, dos que imploram publicamente a caridade e vivem em estado de miséria, exame de menores, a fim de estabelecer a idade aparente dos processados que se encontram doentes ou que assim o declaram, exame e estudo das pessoas em que se presume a existência de uma alteração ou perturbação mental, exame dos intoxicados pelo álcool, pelos alcalóides, e por outras substâncias estupefacientes, quando se imputam a estes a realização de fato delituoso ou que foram lesados pelos mesmos, exame dos que tentam contra a própria vida e dos acidentados.

Camps (1968) diz que a Medicina Legal pode ser definida aproximadamente como a aplicação de conhecimentos médicos na administração da lei e ainda orientar a Justiça. Para Camps (1968), a história da Medicina Legal é mais uma face da história do homem e de suas instituições, pois em ambas existem fatos e mitos. Entre os mitos, é amplamente divulgado que a função do legista seria unicamente esclarecer mortes suspeitas ou violentas. A Medicina Legal, para Camps (1986), seria a chave para se esclarecer fatos do passado não resolvidos ou esquecidos, para a explicação de fenômenos e eventos do presente, e ainda possibilidades de propor para o futuro soluções para os casos que viessem a exigir sua participação.

Dérobert (1974) no primeiro capítulo do seu livro Médecine Légale, após citar diversas definições da Medicina Legal, comenta as diversas apresentações dadas à Medicina 
Legal pelos autores que o antecederam e consolidaram nele a noção de que a Medicina Legal é um caminho, uma via através da qual o médico pode auxiliar a Justiça, mais ainda, acompanhar a evolução e a aplicação dos conhecimentos da ciência na produção dos legisladores, quando se trata de temas que exigem conhecimentos desta área. Para ele a historia da Medicina Legal se confunde com a própria historia da Medicina, pois teria sido através do prestígio da Medicina que os tribunais buscavam médicos para orientar processos. Conclui o autor com frase emblemática do seu entendimento sobre o papel da Medicina Legal (1974: 19) "Le médecin peut être un auxiliaire de la Justice, Il est toujours un rouage essentiel et indispensable de la Société”. Para o autor a Medicina Legal não é uma especialidade médica na acepção do termo; ela é, antes, uma "competência" dada aos médicos para bem auxiliar a Justiça.

Fávero (1991: 21) nos diz que a Medicina não estaria restrita apenas ao diagnóstico e tratamento das doenças, que lhe incumbiria ainda o prevenir "os agravos à saúde do indivíduo isolado e principalmente dos indivíduos em conjunto", trabalho este último no território da saúde pública. À Medicina Legal caberia papel de destaque enquanto ação social, ou seja, "a missão de orientar os legisladores e magistrados na elaboração e aplicação das leis civis e penais do meio coletivo".

França (2008: 1) na introdução do seu livro em oitava edição, "Medicina Legal", nos diz que esta ciência tem "largas proporções e extraordinária importância no conjunto dos interesses coletivos, porque ela existe e se exercita cada vez mais em razão das necessidades da ordem pública e do equilíbrio social”. Continua o autor nos ensinando na mesma página, que a Medicina Legal "não chega a ser propriamente uma especialidade médica, pois aplica o conhecimento dos diversos ramos da Medicina às solicitações do Direito”.

É fácil demonstrar que a grande maioria dos autores, especialmente os do Direito, preocupa-se com a ponta de um processo: a prova. Nós, contudo, nos preocupamos com aquilo que poderá dar origem a uma prova científica. Se não vejamos:

Bentham (1971: 9,10), (primeira edição em Paris, no ano de 1823, Traité des Preuves Judiciaires). Tratado de las Pruebas Judiciales:

El objeto de las leyes cuando son ellas lo que deben ser, es producir, en el más alto grado posible, la felicidad de la mayor cantidad de personas; pero sean tales leyes buenas o malas, solo pueden obrar creando derechos y 
obligaciones". (Tradução livre: o objeto das leis quando elas são o que devem ser, é produzir, no mais alto grau possível, a felicidade da maior quantidade de pessoas; porém sejam tais leis boas ou más, só podem operar criando direitos e obrigações). Ainda, segundo Bentham no mesmo texto acima referenciado, "esas leyes no tendrian ningún efecto si el legislador no crease al mismo tiempo otras leyes, cuyo objeto es hacer cumplir las primeras: son las leyes de procedimiento. Para señalar la diferencia entre unas y otras, llamaremos a las primeras leyes substantivas, y a las segundas leyes adjetivas".

Tradução livre: essas leis não teriam nenhum efeito se o legislador não criasse ao mesmo tempo outras leis, cujo objeto é fazer cumprir as primeiras: são elas as leis de procedimento. Para assinalar a diferença entre umas e outras, chamaremos as primeiras leis substantivas, e as segundas, leis adjetivas.

Tratando, no início do seu livro, dos assuntos pertinentes aos objetivos das leis, Bentham conclui com a seguinte assertiva: "Asi, pues, el arte del proceso no es esencialmente otra cosa que el arte de administrar las pruebas."(Tradução livre: Assim, pois, a arte do processo não é essencialmente outra coisa que a arte de administrar as provas.)

As assertivas de Bentham mostram a orientação que o mundo jurídico freqüentemente usa no trato das leis e na aplicação das mesmas. Mostra, ao mesmo tempo, que o processo judicial tem como corolário simplesmente a administração das provas. Utiliza como conceito operacional, a arte no sentido aristotélico do termo.

A definição de prova segundo Bentham (1971: 21), especialmente no universo do Direito, é feita segundo os critérios e pressupostos que o mesmo retirou da Lógica Clássica. Assim, define o referido autor, a prova:

Qué es una prueba? En el más amplio sentido de esa palabra, se entiende por tal um hecho supuestamente verdadero que se deve servir de motivo de credibilidad sobre la existencia o inexistencia de otro hecho.

Tradução livre: O que é uma prova? No sentido mais amplo desta palavra, entende-se como tal, um fato supostamente verdadeiro que, se presume, deve servir de motivo de credibilidade sobre a existência ou inexistência de outro fato.

Percebe-se, no texto de Bentham, o critério de verdade como o referente explícito para o termo prova. O mesmo autor, no texto subsequiente, estabelece os elementos constitutivos da prova que, segundo ele, deve compreender dois fatos distintos, um que se chama fato principal, como aquele cuja existência ou não, deve-se provar, e outro, que ele denomina de fato probatório, que é aquele que se usa para demonstrar a afirmação ou negação do fato principal. Chega assim, o autor, a uma regra direta: "dado tal hecho, llego a la conclusion de 
la existencia de tal otro."

As determinantes verdade e verificação dos fatos são, na obra de Bentham, os fulcros da prova e sua aplicação no Direito. Prova denominada como arte, especialmente quando aplicável às práticas nos tribunais, onde, segundo o autor referido, atingiria seu maior esplendor. Pois em todo caso, a prova seria um meio para se atingir um determinado fim.

Ao tratar das diversas espécies de prova, Bentham busca relativizar o conceito quando aplicado ao caso em tela, ou seja, ao particular. A palavra prova teria algo de enganador, pois a coisa assim chamada teria força suficiente para o convencimento. Sendo conceitualmente um meio para se atingir a um determinado fim, a prova poderia advir de fontes boas ou más, completas ou incompletas, através das pessoas ou das coisas, poderia ser direta ou indireta, seria também presuntiva ou não. Finalmente, para o autor referenciado, todas as denominadas provas reais são circunstanciais, portanto não têm o caráter de necessário.

Não seria possível a perfeição, nem mesmo a ausência de erro, mas seria desejável a busca por ela na coleta de dados e dos elementos probatórios, pois os detalhes fornecem, quando adequados a cada situação, instrumentos preciosos para construção da prova.

Para Mittermaier (1996: 59), segundo tradução da terceira edição, em Heidelberg (1834), "provar é querer, em substância, demonstrar a verdade e convencer o juiz, o qual para decidir há mister de adquirir plena certeza”. Observa-se nesta assertiva, a mesma busca estabelecida por Bentham e referenciada no texto acima. Busca-se a verdade que tem origem nos fatos conhecidos, verdade esta que tem por objetivo convencer o julgador, portanto, prova destinada ao processo judicial.

A natureza da prova estaria desenvolvida a partir da verdade, da convicção e da certeza. Teria por consequiência, substrato na razão e ainda nos aspectos próprios do psiquismo, enquanto origem das emoções. $\mathrm{O}$ autor não busca revisar o que ele chama de “divisões escolásticas", também não pretende explicar a verdade lógica, que no seu entendimento opor-se-ia à verdade material, posto que aquela seja obtida pelo raciocínio, resulta que aquilo que entendemos não contraria as leis conhecidas.

A verdade no conceito do mesmo autor seria "a concordância entre um fato real e a idéia que dele forma o espírito". Entre os objetivos deste texto de Mittermaier, estaria o explicar-se rapidamente o presumível e o possível logicamente, não discutindo a natureza da 
verdade transcendental. Só lhe interessaria a verdade empírica, pois esta é aplicável às coisas do mundo sensível e, portanto, bastaria para os objetivos do Direito. Nesta sequiência de "não intenções", ainda estaria contemplado o desinteresse pela verdade matemática, pois a verdade histórica é que seria o objeto dos seus estudos, com base nos fatos e em determinados acontecimentos situados no tempo e no espaço.

A convicção nasceria das próprias entranhas da verdade e de certa forma independentemente do espírito que julga. Por outro lado, reconhece o autor, seria de todo ilusório não se perceber que, em toda causa judicial, prevalece a individualidade do julgador, manifestada pelo seu livre convencimento. Neste ponto, a convicção poderia se tornar uma falácia, pois pode ficar sob as influências do momento, as palavras de um terceiro, por exemplo. E se ainda não houver base sólida, o julgador consciente estaria em grande dificuldade no exercer o seu mister. Faz-se necessário, neste cenário, o critério da certeza, como elemento de definição, na visão do referido autor.

A certeza, segundo Mittermaier (1996: 65), exige, para existir, certas condições. "Exige um complexo de motivos consagrados pela razão e pela experiência como podendo servir de base à convicção".

Em segundo lugar, "exige que a preceda um esforço sério e imparcial, aprofundando e afastando os meios que tenderem a fazer admitir a solução contrária". Para o referido autor, quem quer obter certeza não se fecha às dúvidas, antes as acolhe, e só quando as resolve, após minuciosa busca e estudo de todos os indícios, estabelece sua decisão.

Em terceiro lugar, "a certeza não pode existir senão quando tiverem desaparecido todos os motivos tirados das peças do processo, que tenderem a fazer considerar a acusação baseada talvez em uma impossibilidade, ou que vierem dar um resultado positivamente contrário ao que deram os outros motivos".

A quarta condição foi assim estabelecida: "e mesmo os motivos, que só tiveram por apoio uma possibilidade em sentido contrário, quer o espírito vê-los dissipados antes que a certeza predomine".

Finalmente, a quinta condição é assim definida: "pelo que respeita às circunstâncias simplesmente imagináveis, embora não ordinárias, não poderá o espírito deixar de prestar-lhes alguma atenção, desde que houver na causa, indícios por mais ligeiros que sejam, 
estabelecendo uma probabilidade, ainda que a mais difícil". Ao referir-se às condições para se obter certezas, o autor produz, ao mesmo tempo, alguns princípios que se poderia dizer, tem o pendão de poder iniciar o caminho para a prova sob a ótica processual da época.

Quando trata do processo, Mittermaier (1996: 37) reafirma o destino da prova, ou seja, convencer o julgador, tendo como beneficiária, a sociedade:

Devendo toda prova ser feita perante o juiz, e tendo a sociedade uma parte imediata no resultado desse grave negócio, o processo é de mister que seja público, e o debate oral; uma instrução por escrito afastar-se-ia do fim, e seria além disso supérflua; visto que é caso em que o juiz assiste a todo o combate, e decide sem apelação. O princípio que regula a apreciação da prova repousa sobre a máxima que tal apreciação não passa de uma operação ao alcance de todos os cidadãos dotados de sã razão, aperfeiçoados pela educação e pela experiência; e, com efeito, nada mais é que fazer um uso conveniente desse senso íntimo que encaminha todos os homens para a verdade, e decidir, conforme a impressão que produzirão os debates, se o acusado é ou não culpado.

Mittermaier coloca a prova dentro de um cenário peculiar, deve ser feita na frente do julgador e para ele. Pode-se observar por este texto que o julgador acredita que todos os homens tendem à verdade e ao senso crítico. A prova, neste cenário, é obtida a partir de vestígios e indícios que possam reconstituir os fatos e assim chegar à verdade, tendo como corolário o demonstrar-se perante o julgador e o tribunal a relação fatos/verdade e a impressão pessoal dos circunstantes sobre a procedência ou não da acusação ou da culpa.

A obra de Mittermaier tem como característica uma fundamentação lógica da prova em matéria criminal. Inicia seu trabalho com explanação sobre a relevância da prova no sentido geral, do sistema que define se a sentença deve ser feita pelo juiz ou pelo júri e avança com uma teoria da prova baseada na verdade, na certeza e na convicção. Trata da prova por verificação judicial e da sua força probante, das regras que devem nortear a verificação judicial e seus efeitos; aborda também a prova realizada por peritos, onde tece comentários sobre a natureza destas provas, suas características, as regras a serem seguidas pelos peritos e da força probante destas provas. Considera a importância da confissão e da prova testemunhal, orienta sobre o que significa a denominada prova documental; caracteriza a prova por concurso de circunstâncias, considera a situação do concurso das diversas provas ou prova composta e termina descrevendo a prova imperfeita.

Considera-se de muito interesse para a Medicina Legal a apresentação do texto de 
Mittermaier que trata da prova pericial, pois este é, para nós, o campo mais importante de atuação do médico legista, embora o próprio autor estenda a atuação do perito, quando da necessidade de se conferir a realidade de uma confissão ou dos fatos relatados por testemunha. É importante ter-se em mente que o autor viveu no início do século XIX e que embora tenha havido importantes progressos científicos naquela época, nada que se possa comparar à explosão das pesquisas científica no século XX, continuada no presente século.

Mittermaier (1996: 151-184) inicia seu texto abordando a natureza do que ele chama de "exame de peritos", em que seria necessário: "ao se apresentarem na causa criminal questões importantes, cuja solução, para poder convencer o juiz, exija o exame de homens, que tenham conhecimentos e aptidões, técnicas e especiais”. Aponta o autor para as condições em que seriam necessárias as intervenções periciais:

Quando se trata de verificar a existência de certos fatos, e que essa
verificação, para ser bem feita, exige indispensavelmente os conhecimentos
técnicos, de que acabamos de falar: suponhamos o caso em que o exame
tenha por objeto os sinais de virgindade ou a existência de veneno em um
copo. Quando se trata de decidir qual a natureza e quais as qualidades de
certos fatos. Quando, sobretudo a sentença deve ter por base a
admissibilidade de um fato como possível ou provável; tal seria o caso em
que uma testemunha, por exemplo, afirmasse certos fatos, certas relações
entre fatos, e o em que o acusado alegasse a existência de certas
circunstâncias acessórias do crime, cuja demonstração, somente, poderia
estabelecer a sinceridade de sua confissão. Quando se trata de tirar dos fatos
as suas conseqüências, o que só pode fazer o homem de arte.

Mittermaier continua no mesmo texto a fazer considerações sobre a natureza da atividade pericial: seria o perito uma testemunha ou simples auxiliar do juiz? Para ele mesmo esta divisão não contemplaria a realidade da ação pericial, pois em certos casos, quando os peritos são chamados a tratar de questões gerais, eles julgariam, não seriam testemunhas, nos seus misteres, sempre haveria julgamentos concernentes às suas próprias atividades. A argumentação do autor prossegue fazendo referência acerca do ato pericial presenciado pelo juiz. Mesmo nesta situação, a presença do juiz seria unicamente um meio, pois a definição da realidade dos fatos periciais passaria necessariamente pelo julgamento do perito. A decisão sobre a aceitação do ato pericial seria assim atributo do julgador. O exame por peritos na ótica do autor seria uma "prova sui generis", a sua apreciação adviria de princípios que lhe são próprios. Um atributo do ato pericial tem extrema relevância para o autor, a confiança, baseada na arte e na ciência do perito. Para que se possa vislumbrar como algum perito teria a confiança do julgador, Mittermaier (1996: 155) estabeleceu regras: 
Têm direito à confiança, nos limites de sua arte e de suas declarações científicas, aqueles que possuem os conhecimentos especiais exigidos, que sabem nos fatos de seu domínio discernir os caracteres técnicos, ou empregar os meios científicos mais adequados à manifestação da verdade. Depois, o juiz funda-se na lealdade do perito durante as observações que lhe são pedidas; e este muito cuidado deve ter na indagação da verdade só; porquanto a santidade do seu juramento duplamente lhe recorda que dele se espera um exame consciencioso e sincero, e que as suas conclusões vão ditar o julgamento. Tem o juiz o direito de esperar que o perito lhe diga com sinceridade o que tiver observado. A par de toda lealdade, que dele espera, conta o juiz com a sua ciência e a sua prática; supõe que não lhe será muito difícil achar as leis científicas, as experiências suscetíveis de serem aplicadas aos fatos em questão. Supõe que depois de achá-las fará justa aplicação e saberá deduzir as conseqüências, que autorizam a razão e a ciência. As conclusões do perito inspiram confiança tanto maior, quanto mais poderosos forem os motivos principais, e mais bem estabelecida a sua mútua relação, nisso vê o juiz o sinal de um exame bem feito de todas as circunstâncias, e de madureza e solidez nas observações. Enfim, muitas vezes a humanidade dos peritos ainda é uma nova e poderosa garantia.

Considerando-se o fato de que o autor acima referido viveu no século XIX, ele toma o cuidado de estabelecer a relatividade da prova pericial, pois a força probante do exame pericial seria fundamentada em presunções que se encadeiam. E mesmo que se considere nos peritos conhecimentos especiais, as leis científicas de então, no que diz respeito à Medicina Legal, poderiam ser contestadas facilmente e caberia ao julgador a aceitação ou não dos atos periciais.

Quais regras ou normas pré-estabelecidas deveriam nortear o juiz quando da prova realizada por peritos? Quais os critérios para a escolha dos "homens de arte" que Mittermaier entendeu devessem ser seguidos? Quais orientações deveriam ser acolhidas pelos peritos por parte do julgador? Homem do seu tempo, Mittermaier buscou responder a estas e outras questões, indicando quatorze regras para a realização de atos periciais. (1996: 161-171).

1- É o magistrado instrutor, encarregado no processo inquisitorial de pesquisar todos os fatos úteis à manifestação da verdade, que compete, primeiro, chamar os peritos; porém, em qualquer estado da causa, pode o acusado ou seu defensor reclamar que sejam eles ouvidos, sempre que for necessário um exame técnico no interesse da defesa; e também pode-se dar que os juizes definitivos ordenem o exame por peritos como suplementar da instrução.

2- $\mathrm{O}$ inquiridor tem sempre a escolha dos peritos, exceto o caso em que são os julgadores que primeiro reconhecem a necessidade do exame, porque então lhes compete indicar. Se são, as conclusões do acusado que motivam o exame, e embora ele designado as pessoas que quer que sejam ouvidas, não está menos o inquiridor no seu direito, chamando as que quiser; designando este ou aquele perito, o acusado pode fazer recear que tenha em vista um 
homem que sabe ser-lhe favorável.

3- Se a administração tiver nomeado alguns homens da arte para examinar e dar parecer sobre fatos do domínio da ciência deve o inquiridor tomá-los por adjuntos em todos os casos que se estende a sua competência territorial.

4- O primeiro dever do magistrado, a respeito do exame por peritos, é designar sempre, com relação à espécie, os homens os mais idôneos, por sua ciência e sua habilidade prática, para observarem os fatos como convém, e apreciá-los racionalmente.

5- $\mathrm{O}$ acusado tem o direito de recusar o perito designado, sempre que este não oferecer as necessárias garantias de ciência e de habilidade, ou quando a sua imparcialidade puder ser posta em dúvida, e que se lhe possam opor os mesmos motivos, que fariam considerar inadmissível ou suspeita uma testemunha de acusação.

6- Qual o número normal de homens da arte que convém chamar para os exames? Tudo depende dos usos forenses, que muito variam. Argumentando por analogia com a prova testemunhal, onde a unanimidade de muitas testemunhas parece dar maiores garantias, pois que o depoimento de uma serve para ratificar o de outra, estabelece-se como princípio que os peritos não podem ser menos de dois.

7- O homem da arte, quando notificado para servir de perito, tem a obrigação de aceitar o encargo? Depende da posição que ele ocupar, ou, se o quiserem, deve-se distinguir entre aquele que foi oficialmente nomeado para o exame das questões científicas, que tiverem lugar no processo criminal, e o que não recebeu tal nomeação.

8- O juramento do perito é coisa essencial, é uma nova garantia da severidade conscienciosa de seu exame e da sinceridade de suas conclusões; atesta, enfim, a boa vontade em aplicar toda a sua ciência, em fazer contribuir todos os recursos dela para dar às questões propostas uma resposta razoável e positiva.

9- É preciso que os peritos procedam ao exame em presença do juiz? Convém distinguir: ou exame é apenas uma parte da inspeção judicial, como quando, tratando da verificação simultânea dos mesmos objetos, indaga o juiz da existência de certos caracteres, os peritos com outros se ocupam, e é enfim, graças ao concurso dessas duas operações simultâneas, que se pode atingir o objeto final e necessário da dita inspeção; ou então, não é esse o estado das coisas, e o perito é simplesmente chamado para proferir uma espécie de julgamento de arte ou de ciência com respeito a certos objetos transportáveis e que lhe são oficialmente confiados.

10- Qualquer que seja a liberdade deixada ao juiz relativamente ao ponto precedente, é para ele de suma importância precisar com clareza os pontos sobre o que quer o parecer dos peritos, e as questões que eles têm de resolver; o seu parecer motivado não é senão um meio de atingir o fim proposto e o inquiridor, encarregado de dirigir os processos, sabe, melhor do que ninguém, o que tal fim reclama.

11- Os peritos podem pedir ao magistrado instrutor comunicação de todos os documentos necessários para os esclarecer em sua tarefa, como podem concluir porque sejam as testemunhas reperguntadas sobre os pontos capitais.

12- Quando os peritos procedem a um exame em presença do juiz, quando praticam uma autópsia, por exemplo, é preciso que o resultado de suas observações seja imediatamente consignado no auto, e que, sem se afastarem do lugar, e sempre perante o juiz, se faça a descrição dos objetos verificados; assim, facilmente e sem demora se esclarecerá qualquer dúvida, que se 
levante. Seria, entretanto, muito exigir, querer obrigá-los a dar logo o seu parecer motivado e inseri-lo no auto; isto não se pode dar senão em casos muito simples, em que grandes meditações serão supérfluas.

13- Na ocasião dos trabalhos, quando, por exemplo, se pratica a autópsia, deve-se fazer retirar todos os espectadores inúteis; obrar de outro modo será querer dar lugar a todos os boatos falsos que podem renascer de suas palavras irrefletidas; e, coisa ainda mais grave, os resultados do exame podem ser comunicados a outras pessoas, que deles aproveitem; e se verá então um individuo que jamais teve conhecimento algum por si dos fatos da causa, fazer em juízo uma comissão falsa, ou dar falso depoimento, revestido no entanto, dos exteriores da verossimilhança.

14- $\mathrm{O}$ inquiridor como diretor dos processos deve ter sempre o cuidado de ver que o relatório dos peritos esteja em harmonia com o objeto sobre que há de versar a sentença definitiva, porque é seu primeiro dever transmitir aos juízes da causa os materiais completos para a sua decisão; não que com isso queiramos que se submetam as conclusões dos peritos e a sua verdade material a uma nova experiência científica, e que reconheçamos ao inquiridor um direito de opinião soberana (super arbitrium), mas simplesmente queremos dizer que deve o magistrado atender a que as conclusões do relatório correspondam ao fim principal do processo.

O que se pode observar a respeito destas regras estabelecidas por Mittermaier e acima referenciadas, é o perfil processual por ele entendido como o melhor possível. Tal perfil pressupõe e convalida a ampla e irretorquível liberdade do julgador, mesmo perante a prova com fundamentos na ciência. $O$ autor entende a importância da verdade baseada na reconstituição dos fatos, na presunção de que os peritos devam ter ciência e arte, talvez por isso o autor os chame de "homens de arte", entendida esta arte como operação da ciência.

Nos casos específicos, a indicação do perito depende da especialidade de cada um; a credibilidade conferida ao perito nasce no sentimento de confiança que os seus conhecimentos e habilidades demonstrem. As regras acima referidas também tratam das liberdades do perito, no entanto, liberdade esta subalterna ao entendimento do julgador e das leis. Fica também claro que o exame pericial tem a característica do que se denomina hoje em medicina legal, de parecer e que é entendido pelo autor como "opinião", embora com fundamentação na ciência e na arte. Vale à pena ressaltar que os escritos de Mittermaier são do século XIX, portanto devem ser avaliados no seu tempo, especialmente quando trata de questões técnicas de outras ciências que não o Direito.

Nesta obra, Mittermaier aponta, finalizando o capítulo das provas periciais, quais são as regras para a apreciação da força probante do exame por peritos, aludindo quatro regras que deveriam levar o juiz a observar os resultados e a perceber se eles estabelecem relação 
entre os fatos e a verdade, e se as conclusões destes exames podem produzir a convicção no julgador. Para que se possam gerar convicções, as provas devem estabelecer certezas, e estas certezas adviriam dos seguintes pressupostos: (1996: 178- 179).

Dos princípios que o perito tomou por pontos de partida, e das leis científicas a que sujeita os fatos observados; é mister que tais leis e tais princípios sejam reconhecidos infalíveis, para que se façam fé às ditas conclusões; e, também, que a sua aplicação seja rigorosamente exata.

Das deduções motivadas, com cujo auxílio estabelece o referido perito a sua opinião.

Da sua concordância com os dados resultantes das peças do processo. E, neste caso, as contradições, que se derem entre o dizer dos peritos e os depoimentos das testemunhas ou a confissão do acusado, de necessidade devem ser atentamente discutidas. Se os fatos, tais como foram observados pelo perito, são totalmente inconciliáveis com as alegações do acusado ou as declarações das testemunhas; se o relatório se acha, aliás, solidamente motivado, e não dá azo à desconfiança, nele é que se deve acreditar, ou, ao menos, o juiz deverá duplamente pesar e debater as confissões e os depoimentos. Se as contradições entre o perito e as testemunhas ou o acusado deixam as declarações destes últimos sua força inteira, deve-se concluir que se enganou ele, e deve-se não prestar fé ao seu parecer.

Do acordo ou da unanimidade dos peritos, quando são muitos. Se alguns houver de opinião contrária; cabe distinguir: ou essa contrariedade se dá quanto aos fatos observados, ou só existe quanto às conclusões que cada um quis tirar. No primeiro caso, se os resultados do exame, que um tiver feito, forem corroborados por outras provas, independentes do mesmo exame, é à sua opinião que se deve dar preferência.

Depreende-se das normas acima referenciadas, que Mittermaier as elaborou nos mesmos critérios de verdade, certeza e convicção que permeiam toda sua obra. Exigir-se que leis e princípios da ciência sejam infalíveis e que sua aplicação seja exata, foge assim ao que se pode denominar de ciência, mesmo no século XIX, quando se começava a vislumbrar os desdobramentos da pesquisa científica. Naquele século, a ciência podia ainda buscar certezas, pois a complexidade da pesquisa era menor. O brilhantismo da obra de Mittermaier está na sua capacidade de tornar clássicos os princípios e as proposições que defendia, sendo até hoje referência no estudo da prova em direito criminal.

Foram selecionados como referência para a noção de prova no Direito, autores que se tornaram clássicos neste tema. Como esta Tese perpassa o conceito de prova em Medicina Legal, as referências ao mesmo tema no Direito servem, por analogia, para que se possa refletir e comparar os conceitos de prova em Medicina Legal em seu tempo e nos dias de hoje.

Outro grande pensador do Direito, quando se trata do estudo da prova, é Nicola 
Framarino Dei Malatesta, (primeira edição: Logica delle Prove in Criminale, 1895, TorinoItália), que inicia sua obra tratando dos estados de espírito do homem, quanto ao conhecimento da verdade. Envereda, a seguir, pelo estudo da prova no sentido lato, procura uma classificação das provas fundamentando-as nos diversos tipos de indícios, observa o que ele denomina de prova real e prova pessoal, trata da divisão formal das provas (prova testemunhal, documental e material) e conclui sua obra com um convite a novas reflexões, onde o leitor e estudioso de sua obra podem ter sua participação.

Partiu Malatesta, segundo suas próprias palavras, “do axioma jurídico de que não há pena legítima sem a certeza sobre o fato da delinqüência. Começamos a estudar tal certeza". Note-se que o foco de suas reflexões no estudo da prova é a certeza e por extensão, a verdade. Malatesta (1960: 19), definiu:

A prova é o meio objetivo pelo qual o espírito humano se apodera da
verdade, sua eficácia será tanto maior quanto mais clara, mais plena e mais
seguramente ela induzir no espírito a crença de estarmos de posse da
verdade. Para se conhecer, portanto, a eficácia da prova, é preciso conhecer
como se refletiu a verdade no espírito humano, isto é, importa conhecer qual
o estado ideológico, relativamente à coisa a verificar, que ela criou no
espírito com a sua ação.

Malatesta (1960: 20,21) aborda, em seguida, os pressupostos que devem nortear o espírito humano no trato da verdade já que, em relação ao conhecimento, as situações que se põem são: a ignorância, a dúvida e a certeza. A ignorância nada revela, a dúvida é definida por ele como "um estado complexo" entre a afirmação e a negação, pois dependendo da maior ou menor presença de motivos negativos ou afirmativos, tem-se a improbabilidade quando predominam os motivos negativos e, quando se igualam os motivos, aparece aquilo que é crível; já quando prevalecem os motivos afirmativos sobre os negativos, tem-se a probabilidade.

Na busca da certeza, Malatesta (1960: 22), no mesmo texto, trata-a como "conhecimento afirmativo triunfante", procurando demonstrar sua importância. Entendendo que a mesma é um estado de espírito decorrente da verdade, assim a define: "a verdade, em geral, é a conformidade da noção ideológica com a realidade; a crença na percepção desta conformidade é a certeza".

A prova no ideário de Malatesta é o centro do processo, portanto, da atividade jurídica. Urge, no entanto, que seja baseada na certeza e não na probabilidade, que seja 
construída na objetiva verificação dos fatos e que sua apreciação tenha como base tanto o seu lado puramente intelectual fundado na reflexão e dedução lógica, quanto na verificação histórica dos elementos que a constituem, através do método indutivo e de observação.

Quando transpõe para o processo penal as suas reflexões sobre a prova, assim se pronuncia Malatesta (1960: 88,89):

Importa ainda observar que o fim supremo do processo judicial penal é a
verificação do delito, na sua individualidade subjetiva e objetiva. Todo o
processo penal, no que respeita ao conjunto das provas, só tem importância
do ponto de vista da certeza do delito, alcançada ou não, pois que qualquer
juízo não se pode resolver senão numa condenação ou numa absolvição, e é
precisamente a certeza conquistada do delito que legitima a condenação,
como é a dúvida, ou, por outras palavras, a não conquistada certeza do
delito, que obriga à absolvição. O objeto principal da critica criminal é,
portanto, indagar como, da prova, pode legitimamente nascer à certeza do
delito; ou, em outros termos, o estudo das provas de certeza. Não é só por
isso que as provas de probabilidade devem ser banidas do processo criminal;
elas, além de servirem para a legitimação da potestas inquirendi, podem
servir mais, no seu conjunto, à constituição de uma prova cumulativa de
certeza, capaz de legitimar a condenação por parte da potestas judicandi.
Mas disto mesmo deriva que as provas de probabilidade, como tal, não são
consideradas senão quando capazes de constituírem uma prova cumulativa
de certeza; sendo sempre verdade, por isso, que o objetivo principal das
investigações da crítica criminal é o exame das provas de certeza.

Quando trata da prova em geral e especula sobre a probabilidade e a certeza, Malatesta busca deixar claros os conceitos tanto de probabilidade quanto de certeza, e ainda das gradações possíveis da probabilidade e que não existiriam na certeza, apontando também os erros de linguagem que existem quando se usam termos como: "prova plena e semiplena". Contesta ainda e aponta os cuidados no uso das palavras: "meia probabilidade e probabilíssimo", pois podem induzir ao erro, quando se as usam como similares à certeza.

Assim, Malatesta acentua a questão da linguagem, do discurso, dos conceitos e da relação entre eles, que seria aquilo que chamaríamos, com Gilles Granger, de Verificação. Mas o que é verificar, para ele? É perguntar-se sobre a adequação à experiência do discurso no qual se pretende exprimir um conhecimento. Mas é também, examinar a natureza da relação que se estabelece entre um enunciado e o sistema do qual é tirado em função das regras de conformidade do pensamento com o mundo, mas, sobretudo com ele mesmo. No processo científico, tanto um quanto outro precisam ser levados em conta para captar o próprio conceito de verificação, chave de toda obra científica. (Granger, 1992). 
Como uma visão prévia do desenvolvimento de sua obra, Malatesta (1960: 125) estabelece a classificação que ele julga apropriada para as provas:

A prova pode ser considerada sob três aspectos igualmente essenciais: quanto ao objeto, quanto ao sujeito e quanto à forma. Quanto ao objeto a prova se divide em prova direta e indireta; quanto ao sujeito, em prova pessoal e real; quanto à forma, em prova testemunhal, documental e material.

Via de regra, os autores do Direito, ao se reportarem ao tema prova, o fazem tendo como corolário, o critério do estabelecimento da certeza como expressão da verdade. Assim também fez Neves e Castro (2000: 32), ao dizer: "no sentido lato, a prova é o meio pelo qual a inteligência chega à descoberta da verdade". Enquanto a obra de Bentham pontua com observações e análises críticas a prova legal, Mittermaier iniciou um trabalho de organizar as provas, em todas as nuances de sua época.

Malatesta introduz definitivamente a Lógica na análise da prova, aliás, este é o enfoque que pretendemos seguir nos dias atuais, à luz da ciência e até da proto-ciência contemporâneas, com seus modelos e sistemas teóricos.

Mudança igualmente importante, a nosso ver, na estrutura judicial do processo, é proposta por Gorphe, na obra L'appreciation des Preuves en Justice, escrita na década de 30, do século XX, portanto, antes da segunda guerra mundial. $\mathrm{O}$ autor relata que fortes impulsos mobilizaram o Direito em seus velhos recintos, trazendo um espírito novo, especialmente no Direito Penal, que era apenas abstrato e agora tende a ser concreto, individual e humano. Alude ainda à chegada à cena do Direito, de conhecimentos como a Criminalística, a Psicologia Judicial, as aplicações da Lógica, da Moral e da Criminologia, que propiciaram a construção de método judicial apropriado que, aliado à capacidade crítica do julgador, ajuda a diminuir os erros judiciais. Segundo a ótica de Gorphe (1955: 10), a observação dos fenômenos naturais e das ações humanas que são elementos das provas, seriam regidos por leis físicas e psicológicas e seria inaceitável examiná-los sem princípios nem método. O texto a seguir, deste mesmo autor, demonstra sua proposta:

El descubrimiento de la verdad en el juicio no realizará positivo avance hasta que el antiguo formalismo del procedimiento, vestígio de la época romana, suceda el examen crítico de las pruebas, con médios psicológicos y de otra índole que pueda la ciência poner al alcance de los jueces. No excluirá ello, ciertamente, el empleo de la intuición; antes bien, permitirá ejercela más utilmente, combinada con el pensamiento experimental y crítico. 
Comprobamos aquí, como en otras ocasiones, que los mejores resultados provienen de la cooperación entre los diversos modos del pensamiento. La actividad intuitiva desemboca en la fantasia cuando no se encuentra constantemente dirigida y fiscalizada.

Tradução livre: A descoberta da verdade em juízo não realizará avanço positivo até que o antigo formalismo do procedimento, vestígio da época romana, seja sucedido pelo exame crítico das provas, com meios psicológicos e de outra índole que a ciência possa por ao alcance dos juizes. Não se excluirá certamente, o emprego da intuição; antes, permitir-se-á usála com mais utilidade, combinada com o pensamento experimental e crítico. Comprovamos aqui, como em outras ocasiões, que os melhores resultados provêm da cooperação entre os diversos modos do pensamento. A atividade intuitiva desemboca na fantasia quando não se encontra constantemente dirigida e fiscalizada.

Gorphe (1955: 9) relata o que ele considera como fases da evolução do processo probatório ao longo da História. Ter-se-iam cinco fases, uma denominada de "étnica", aquela das sociedades primitivas, onde prevaleciam as impressões pessoais e os flagrantes de delito. A seguir, veio a "via religiosa ou mística", onde o que importava era o juízo de Deus, ou dos deuses, com provas como as ordálias e as posturas de fé. Na sequiência se instala a "fase legal", quando a lei fixa os meios de prova e o seu valor probatório, considerando a confissão como a rainha das provas, mesmo quando conseguida sob tortura. Sucede a esta última a "fase sentimental", onde o juiz aprecia livremente as provas, usando unicamente a livre convicção. Surge, finalmente, a época da "ciência", onde a prova é construída sobre bases científicas, muitas vezes em laboratórios, com o concurso de médicos, químicos, físicos e outros profissionais da ciência. $\mathrm{O}$ autor trata, nesta obra, da necessidade de um método técnico que apreciaria as provas baseado na Lógica, na psicologia e na prática judicial. Aponta, assim, para uma ciência positiva como fundamento da prova. Gorphe faz classificações, demonstra a importância dos caminhos dedutivo, indutivo e das inferências, fundamenta as investigações psicológicas, cita um método geral de exame crítico, comenta os vestígios, indícios e presunções. Aborda então os procedimentos científicos que devem fundamentar as perícias e finaliza com um estudo sobre as relações entre as provas. Na conclusão de seu trabalho, enfatiza que a certeza só pode ser alcançada através de um método que reduza os riscos de erros, ou seja, uma certeza racional e positiva, porém, ainda relativa. A racionalidade de Gorphe fez com que ele estabelecesse este pressuposto a qualquer teoria: a certeza racional e positiva ainda que relativa.

No sentido contemporâneo da ciência, onde a relatividade e até a incerteza matemática constituem um fundo de quadro habitual, o seguinte texto de Granger (1994: 9) bem 
especifica os cuidados que se deve ter na construção da prova científica ou da apreciação que se faça da ciência no lato sensu ou no stricto sensu:

Hoje, no teatro desmedidamente extenso das representações de nosso mundo oferecidas a todos pelos textos e pelas imagens, a ciência certamente aparece como uma personagem essencial. Misteriosa, porque o pormenor de sua figura não está ao alcance pos próprios cientistas; tutelar, porque dela dependem as maravilhosas máquinas que povoam os lugares em que vivemos; inquietante, porque estamos conscientes dos poderes antinaturais e aparentemente ilimitados que um tal saber foi e será capaz de desencadear.

O texto final da obra de Gorphe bem resume as propostas contidas em seu livro e mostra uma mudança substancial, em comparação com os autores de formação clássica. Assim é concluído este trabalho: (1955: 485-486)

Tan solo a costa de metódicos esfuerzos resulta posible llegar a discernir la verdad del error y a apoyar la convicçión del juez sobre seguras pruebas. Um paso importante se daria si el espíritu científico, que tantas experiências há realizado en otros terrenos, consiguiera introducir en el examen de las pruebas una disciplina más estricta, al sustituir una apreciación subjetiva y arbitraria, fruto de la "convicción intima", por un fallo positivo y critico, basado en principios rectores y que aspirara a una verdadera certidumbre. Sin duda, no cabría pretender, ante la Justicia, una rigurosa exactitud, como en la ciência: la Justicia continuará siendo un arte, y un arte humano, falible en consecuencia. Mas el progreso consiste em reducir los riesgos de error, en todo caso constitutivos de algo grave. Trajano proclamó esta atinada sentencia: Satius esse impunitum relinqui facinus nocentis quam innocentem damnare.

No solamente por interes inmediato de los ciudadanos, sino tambíen en aras del superior interes de la Jusiticia y del Estado, resulta preferible, como se há repetido, dejar escapar a diez malhechores que castigar a un solo inocente: la eficacia ética y social de la Justicia descansa sobre la creencia de que su espada no caerá sino contra los culpables; si no, como afirma Rittler, la Justicia pareceria servidora del sacrifício humano, no ya como una elevada y santa divinidad, sino como cruel Moloc, y el pueblo destrozaria tal ídolo. La finalidad de las pruebas debe consistir en obtener una certeza, aunque con frecuencia hagan en mitad de su camino; es decir, en una simple probabilidad o verosimilitud.

Tradução livre: Tão só a custa de metódicos esforços resulta possível chegarse a discernir a verdade do erro e apoiar a convicção do juiz sobre provas seguras. Um passo importante ocorreria se o espírito científico, que tantas experiências tem realizado em outros terrenos, conseguisse introduzir no exame das provas uma disciplina mais estrita, ao substituir uma apreciação subjetiva e arbitrária, fruto da "convicção íntima", por sentença positiva e critica, baseada em princípios diretores e que aspirasse a uma verdadeira certeza. Sem dúvida, não caberia pretender, diante da justiça, uma rigorosa exatidão como na ciência: a justiça continuará sendo uma arte, e uma arte humana, falível conseqüentemente. Mas o progresso consiste em reduzir os riscos de erro, que constitui em todo caso algo mais grave. Trajano proclamou esta assertiva sentença: Satius esse impunitum relinqui facinus nocentis quam innocentem damnare. Não somente pelo interesse imediato dos cidadãos, como também pelo interesse superior da Justiça e do Estado, 
resulta preferível, como se tem repetido, deixar escapar a dez malfeitores que castigar um só inocente: a eficácia ética e social da Justiça descansa sobre a crença que sua espada não cairá senão contra os culpados; se não como afirma Rittler, a Justiça pereceria servidora do sacrifício humano, não com uma elevada e santa divindade, mas como um cruel Moloc, e o povo destruiria este ídolo. A finalidade das provas deve consistir em obter uma certeza, ainda que com freqüência se chegue à metade do caminho; ou melhor, há uma simples probabilidade ou verossimilhança.

A afirmação de Gorphe (1955: 485), segundo a qual a certeza à qual se pode chegar só é possível através de método que reduza erros, seria uma certeza racional e crítica, porém relativa; às vezes reduzida à probabilidade e outras vezes à verossimilhança, mostra a evolução conceitual que ocorreu entre o século XIX e o século XX, pois naquele havia o libelo sobre a necessidade da certeza; neste, percebeu-se que isto é desejável, mas algumas vezes não conseguida.

A Medicina Legal transita hodiernamente por vários campos da ciência, tendo como base pressupostos, proposições e conceitos lato sensu das ciências biológicas e físicas, atuando em relação ao ser humano desde antes da sua concepção, até bem depois da sua morte. Perscruta a genética, prolonga a sua atuação nas diversas especialidades médicas, fundamenta sua atividade nos mais diversos corolários da biologia e da antropologia, continua seu mister nas relações com a justiça e a sociedade.

Diante de tão vasto campo de atuação, torna-se essencial, seguindo a "lógica" de Gorphe, discutir o que significa a certeza, mesmo que relativa, e se é possível escalonar-se este "grau de certeza", a partir de provas com fundamentação científica.

A obra de Gorphe (1955: 487) termina com um chamamento à importância do método, que se situa, entre "el moderno espíritu científico y las preocupaciones prácticas de los estrados judiciales", (o moderno espírito científico e as preocupações práticas das salas dos tribunais). Busca o autor, baseando-se na filosofia de Pascal sobre a razão, a motivação final para sua obra.

Inspirada en la antigua noción francesa de la razón crítica, que según Pascal constituía la facultad de las pruebas, de los médios y del ambiente, no desdeña los diversos procedimientos creados por la experiência profesional, con la condición de saber integrar cada uno en su lugar; de igual modo que en la juiciosa tradición pascaliana, la razón y el corazón ( o la intuición), lejos de oponerse, se completan con armonía y mutuamente se iluminan. 
Tradução livre: Inspirada na antiga noção francesa de razão crítica, que segundo Pascal constituía a faculdade das provas, dos meios e do ambiente, não desdenha os diversos procedimentos criados pela experiência profissional, com a condição de saber integrar cada um no seu lugar, de igual modo que na judiciosa tradição pascaliana, a razão e o coração (ou intuição), longe de se oporem, completam-se com harmonia e mutuamente se iluminam.

Enfoque diverso, sobre o universo da prova na prática judicial, ou ainda na vivência processual, é dada por Erich Döhring, na obra Die Erporschung des Sachverhalts im ProzessBeweiserhebung und Beweiswurdigung, publicado em Berlim, no ano de 1964. Tal obra foi traduzida para o espanhol, em 1972, nas Ediciones Jurídicas Europa-America, de Buenos Aires, com o titulo: La Investigación del Estado de los Hechos en el Proceso - La Prueba su Practica y Apreciacion. Este livro concentra um esforço teórico importante sobre a prova como instrumento judicial, ou seja, o que realmente importa é a denominada prova judiciária, com os cuidados inerentes aos últimos dias do século XX. O título central do livro é sobre a prova, sua prática e apreciação, ou seja, não vai se deter sobre os fundamentos teóricos nem filosóficos ou ainda conceituais da prova, mas sim numa visão pragmática, técnica, utilitária e especifica da prova, centrada no processo judicial, no Direito Penal ou Civil. Mostra o papel do agente investigador que deve observar a singularidade da valoração conclusiva do material probatório no seu conjunto, estabelecendo ligações entre os documentos, testemunhos, resultados de inspeções oculares, informes dos peritos, etc. buscando determinar se o conjunto forma um todo unitário e coerente, que permita ao julgador ver detalhes e ao mesmo tempo desligar-se dos mesmos para contemplar um quadro geral, que gere convicções.

Döhring aprofunda as reflexões sobre a prova judiciária, abordando os meios probatórios inadmissíveis, a formulação dos contextos e do quadro que envolva o conjunto das provas.

Trata dos obstáculos à formação de uma visão deste conjunto, da retificação possível dos resultados conseguidos, da eliminação das dúvidas e, ainda, tece considerações sobre as possibilidades dignas de crédito em relação à prova, onde ela pode ser influenciada decididamente pelo fenômeno psicológico. (1972: 412)

Cuando se trata de saber si se le puede probar al reo el hecho que se le imputa, hay que pensar siempre si no cabrá contemplar combinaciones de hechos en las cuales éste quede descartado como autor. A veces, el operante ni siquiera se plantea esa cuestión o la contesta sólo someramente, obedeciendo al puro sentimiento. 
Tradução livre: Quando se trata de saber se se pode provar ao réu, o fato que lhe é imputado, há que se pensar sempre se não se poderá contemplar combinações de fatos nos quais este fica descartado como autor. Às vezes, o operador nem sequer estabelece esta questão ou a contesta só superficialmente, obedecendo ao puro sentimento.

As observações do autor prosseguem em sua extensa contribuição à prova judiciária, demonstrando a necessidade de o julgador contemplar a exclusão de possibilidades demasiado remotas, enfatizando que os procedimentos a observar devem ser os mesmos, tanto no Direito Penal, como no Direito Civil. Argumenta que se deve buscar a não-contradição na avaliação das provas, que se devem examinar detalhadamente as possibilidades discrepantes, ficar-se entre o otimismo e a cautela quando da averiguação dos argumentos que possam contraditar a reconstrução do estado dos fatos que é perseguida.

A medida da prova, na visão de Döhring, (1972: 422), determina, que: "una decisión judicial sólo puede estar fundada en una prueba plena”. A condenação só pode advir quando constatada a certeza dos fatos confirmados em provas consistentes e dentro das normas e das leis.

Cuando se pregunte si en un determinado aspecto está dada la prueba plena, serán menester dos tipos de reflexiones. Por un lado, habrá que ponderar qué requisitos debe reunir la prueba en casos como el que se investiga, o sea qué cartabón general corresponde aplicar al material probatório. Luego, habrá que ver si, conforme a esse cartabón, está dada o no en el caso sub examen la cantidad de prueba requerida. Quiere decir que, por un lado, hay que establecer el cartabón aplicable y, por el otro, aplicarlo correctamente al material fáctico aportado.

En eso pueden ocurrir fallas, tanto porque el julgador desconozca la medida abstracta de la prueba, como porque no sepa determinar si se la ha llenado en el caso que se está investigando.

Tradução livre: Quando se pergunta se em um determinado aspecto a prova é plena, será mister dois tipos de reflexões. Por um lado, haverá que ponderar quais requisitos deve reunir a prova nos casos como este que se investiga, ou seja, que quadro geral corresponde aplicar ao material probatório. Logo, haverá que se ver conforme esse quadro se está considerado ou não nesse caso a quantidade de prova requerida. Quer dizer que por um lado há que se estabelecer o quadro aplicável e por outro lado, aplicá-lo corretamente ao material fático entregue. Nisso pode ocorrer falhas, tanto porque o julgador desconheça a medida abstrata da prova, como porque não saiba determinar se o que foi encontrado, tenha a ver com o caso que se está investigando.

Outra reflexão importante de Döhring se verifica quando aborda a questão da verossimilhança. Embora em alguns países da Europa, a verossimilhança tenha sido aceita como prova, em algumas circunstâncias, Döring considera este conceito pouco idôneo para configurar a prova. Porém, segundo o mesmo autor, nas etapas iniciais do processo de prova, 
a verossimilhança pode ser considerada, posto que, naquelas ocasiões, ela pode ajudar na busca da certeza. A certeza plena é aquela que o autor considera como essencial no evoluir do processo. Para tanto, devem existir requisitos mínimos para se considerar os elementos probatórios, uma concretização de linha diretriz na reconstrução dos fatos, a certeza de que o imputado cometeu os fatos relatados, consubstanciada em investigação criteriosa, na quantidade de provas reunidas e nos questionamentos devidamente respondidos.

O fecho da obra de Döhring é feito na avaliação do convencimento do julgador, que deve se basear na certeza pessoal, fundamentada na convicção e na certeza como expressão da verdade dos fatos, na avaliação do conjunto das provas, na superação das dúvidas, na relação entre o convencimento interno que expressa a conviç̧ão e as precauções com o que ele denomina de crítica do convencimento subjetivo, na possibilidade de submeter à prova a certeza interna, na resistência contra influxos ilegítimos na formação do convencimento, de tal forma que o julgador exerça o seu múnus como corolário na prática da justiça.

Os autores acima referenciados, desde Bentham até Döhring, tratam dos fundamentos da prova judiciária através de proposições, inferências e conceitos que implicam a busca da verdade, tendo como fundo de quadro a verdade. Verdade esta, estabelecida graças aos fatos concretos, históricos, referenciados em vestígios, indícios e presunções.

Pensamos que o ideal seria descobrir nos fatos concretos uma estrutura que deve ser análoga à construção de um edifício, que sustentado por colunas mestras interligadas, lhe dão sustentação, desde que a estrutura - no sentido piagetiano do termo, tanto no conceito de prova, quanto no das colunas mestras do edifício - seja passível de crítica e análise, porém tenha capacidade de resistir, tanto no campo teórico, quando se fala de prova judiciária, quanto na "resistência dos materiais" que constituem as referidas colunas, ou seja, o método.

Piaget, ao tratar do Estruturalismo, define estrutura segundo a ótica da matemática, enfatizando que diversos autores dizem ser difícil caracterizá-lo, pois este conceito estaria eivado de formas as mais diversas, dificultando a possibilidade de se encontrar um elemento comum a estas formas diversas. No entanto, Piaget busca, em sua obra Estruturalismo (1967/2003), sintetizar o conceito, desde que se perceba a existência do que ele denominou de dois problemas, o ideal positivo (no sentido de ater-se aos fatos e não naquele do Positivismo lógico ou da teoria de Auguste Comte) que recobre a noção de estrutura, na evolução dos 
diversos entendimentos do estruturalismo e o que ele denominou de "intenções críticas que acompanharam o nascimento e o desenvolvimento de cada um deles, em oposição às tendências reinantes nas diferentes disciplinas". Considerando-se o peso das reflexões teóricas defendidas por Piaget neste livro, em atenção à necessidade de entender o que é estrutura como conceito, transcrevemos o que nos legou o autor: (1967/2003: 8-9)

Em uma primeira aproximação, uma estrutura é um sistema de transformações que comporta leis enquanto sistema (por oposição às propriedades dos elementos) e que se conserva ou se enriquece pelo próprio jogo de suas transformações, sem que estas conduzam para fora de suas fronteiras ou façam apelo a elementos exteriores. Em resumo, uma estrutura compreende os caracteres, de totalidade, de transformações e de autoregulação. Em uma segunda aproximação, mas pode tratar-se de uma fase bem ulterior e também sucedendo imediatamente à descoberta da estrutura, esta deve poder dar lugar a uma formalização. Contudo, é preciso deixar claro que essa formalização é obra do teórico, ao passo que a estrutura é independente dele, e pode traduzir-se imediatamente em equações lógicomatemáticas ou passar pelo (momento) intermediário de um modelo cibernético. Existem, portanto, diferentes graus possíveis de formalização, dependentes das decisões do teórico, ao passo que o modo de existência da estrutura que ele descobre deve ser determinado em cada domínio particular da pesquisa.

Dentre os autores brasileiros do Direito, Moacyr Amaral Santos é referenciado nesta Tese, por sua extensa obra sobre as provas judiciárias, constituída de cinco volumes, com ampla digressão sobre o tema e tendo como titulo: Prova Judiciária no Direito Cível e Comercial. No primeiro volume, ele trata da parte geral e doutrinária da prova, tendo como referências autores como Bentham, Malatesta, Castro Neves, Carnelutti, Gusmão, Chiovenda, Lessona, Montesquieu, Fustel de Coulanges, Salvioli, Pontes de Miranda, Clóvis Bevilacqua, Melo Freire, João Monteiro, Mortara, entre diversos outros doutrinadores do Direito. No segundo volume, o autor trata da confissão, a outrora rainha das provas. No terceiro volume, é tratada a prova testemunhal, onde os aspectos psicológicos são enfatizados. No quarto volume, são estudados os documentos e, finalmente, no quinto volume, são abordados os exames, as presunções e indícios. Abordaremos nesta Tese o primeiro e o quinto volumes da obra porque nestes dois livros pode-se perceber a convergência no estudo da prova, já referenciado acima, nas obras de Bentham, Malatesta, Mittermaier, Gorphe e Döhring.

Em suas notas preliminares, Santos (1970: 11) inicia a digressão sobre a prova no direito civil e comercial, abordando a origem do vocábulo "prova". Fundamenta as diversas acepções desta palavra, tendo como base a verdade dita objetiva, a certeza e a convicção, que 
definiriam o conceito de prova judiciária. O embasamento teórico necessário para esta obra clássica do Direito brasileiro foi encontrado nos trabalhos de Neves e Castro, Malatesta e Bentham. Portanto, os conceitos iniciais deste tema são os mesmos já discutidos acima nesta Tese, através dos autores acima referenciados. Os vínculos da teoria da prova com a prática do Direito estão consagrados pelo autor (nas páginas 15-20), ao proferir:

A todo direito corresponde uma ação, que o assegura. $\mathrm{O}$ titular do direito violado ou ameaçado pode reclamar as garantias sociais de que a lei o cerca usando de uma ação, que se exercita através de um processo, pelo qual o direito se restaura ou se defende. Na ação há, assim, sempre, a afirmação de um direito violado ou ameaçado. Donde haver sempre a alegação de um fato causador da violação ou da ameaça. Daí dizer-se que a ação tem por fundamento um ponto de fato. O ponto de fato deve ser provado, porque é na verdade resultante dessa prova que a sentença a ser proferida no processo, vai se assentar para restaurar em sua inteireza e plenitude o direito ameaçado ou violado. A questão de fato se decide pelas provas. Por estas se chega à verdade, à certeza dessa verdade, à convicção. Em consequiência, a prova visa como fim último, incutir no espírito do julgador a convicção da existência do fato perturbador do direito a ser restaurado. A finalidade da prova não é outra senão convencer o juiz, nesta qualidade, da verdade dos fatos sobre os quais ele versa...Pela prova, procura-se averiguar a verdade dos fatos alegados pelos litigantes. A decisão assenta-se na prova dos fatos, na apuração dos fatos. (...) A certeza é uma e não pode deixar de ser uma só. Em matéria de certeza, não existe meio termo; tem-se a certeza ou não se tem. Por isso mesmo a convicção não tem gradações. (...) A convicção deve ser formada no exame direto das provas... Deve ser obtida pela produção da melhor prova, no sentido subjetivo, objetivo ou formal.

Santos (1970), buscando uma definição, diz que "prova é a soma dos fatos produtores da convicção, apurados no processo".

Quando trata da prova pericial, Santos (1968: 9) relata que este tipo de prova é considerado como prova indireta porque seria trazida ao processo por "interposta pessoa", veja-se o referido texto na obra do autor, quando explica e disserta sobre o tema.

Sob a denominação de "exames periciais", o Código de Processo Civil (...), abrange aqueles meios de prova que se produzem mediante a intervenção de perito, quais sejam o exame propriamente dito, a vistoria, o arbitramento e a avaliação. Se a prova se produz no processo por meio de perito, isto é, por meio de pessoa encarregada expressamente de certificar-se dos fatos para dar conhecimento deles ao juiz, será ela o resultado de um exame pericial ou, mais simplesmente, de uma perícia. A palavra perícia abrange toda espécie de exame. Mas perícia, bom é que se repita, pressupõe a figura do perito: é prova indireta, porque trazida ao processo por interposta pessoa. Quando o exame é feito pelo próprio juiz, diretamente sem a intervenção de interposta pessoa - hipótese não cogitada pela lei processual pátria, mas que é juridicamente admitida - dar-se-á aquele meio probatório a que os alemães 
chamam de ausgenschein, os italianos de ispezione giudiziale, os franceses de descente aux lieux, os espanhóis de inspecion personal del juez, e a que Lopes da Costa denomina de exame judicial.

Santos (1968: 10-22) faz sinopse histórica da prova pericial desde a antiguidade até o século $\mathrm{XX}$, na qual mostra as evoluções conceituais e operacionais da prova nos diversos povos, onde a lei era, de alguma forma, predominante. A referida sinopse é iniciada pela afirmação de que, no antigo Egito, já existiam vestígios de perícia. Fraga, apud Santos, citando Heródoto, refere a seguinte situação, onde havia, naquela civilização, um rudimento de prova pericial:

(...) quando o rio despojava alguém da quota agrária, a pessoa lesada ia procurar o rei, a quem dava parte do ocorrido; então este enviava ao lugar da situação do lote inspetores que o mediam para saber a área diminuída e a diminuição proporcional que devia sofrer no pagamento do tributo.

Pode-se daí inferir que estes inspetores seriam àquela época, os antecessores dos peritos agrários de hoje, os agrimensores. Os Hebreus e os Gregos copiaram dos Egípcios os fundamentos judiciais no que tange a ocupação de terras e os respectivos tributos. Continuando o périplo histórico que fez em relação ao estudo da prova judicial, Santos refere ter encontrado nos registros da história, o inicio concreto da prova pericial, em Roma. Desde o Direito Decenviral das Doze Tábuas, passando pelo período da realeza, onde o rei fazia o papel do magistrado e por conseqüência, do acolhimento ou não das "provas", e com o crescimento das pendências, tal função passa para o Senado, nas pessoas dos senadores. A evolução dessas práticas levou a uma nova mudança, onde o processo foi dividido em duas etapas: in iure e in iudicio. Santos descreve, então, a lógica processual, a partir dessa divisão: (1968: 11-12-13-14)

No processo in iure o magistrado apreciava a ação sob o aspecto jurídico e legal, nele não se cogitando da instrução da causa. A instrução e decisão desta se operavam no processo in iudicio selectorum. De sorte que em regra o nomeado é a um tempo juiz e perito. O mesmo ensina Scialoja: "o procedimento simples e de ordinário seguido consistia em nomear-se juiz uma pessoa entendida na matéria objeto da litis; de sorte que o juiz não tinha necessidade de chamar um perito, porque ao mesmo tempo ele era juiz e perito". De tal modo se explica porque acrescenta Alcântara Machado com apoio em Mayns e Van Metter - na primeira fase do processo civil dos romanos só excepcionalmente ocorreria o exame por meio de peritos... Com toda a certeza, em ações outras, em casos especiais e conforme as circunstâncias, o juiz delegaria a terceiros, por serem mais entendidos na matéria, o encargo de inspecionar pessoas ou coisas. Comprova essa asserção o papiro Abbot, do qual Alcântara Machado fornece notícia circunstanciada e a respectiva tradução. Trata-se de documento do ano 130 
da era cristã, ao tempo do imperador Adriano Trajano Augusto, e que corresponde a um autêntico laudo do médico Caio Minucio Valeriano, do burgo de Caranis, a propósito de ferimentos na cabeça, recebido por um indivíduo chamado Mysthorion. "Provado está - conclui o jurista patrício com a mais resplandecente evidência, que figurava, há dezoito séculos, a perícia médica na prática forense do império romano". Com Diocleciano, no ano 294 da era cristã, estabelece-se, definitivamente, com a extinção do processo das fórmulas, o processo dito extraordinário - cognitio extraordinária - que suprimiu os dois momentos da ordo - in iure e in iudicio,concentrando-se as funções de declarar o direito e de julgar o fato na mesma pessoa, isto é, na pessoa do magistrado, perante quem se desenvolvia a relação processual desde a petição inicial até a execução. Então a figura do perito aparece comumente...Versando a causa, por exemplo, sobre gravidez de mulher divorciada, o juiz era autorizado a ordenar exame por "três obstetrices, probata et artis et fidei, quae eam inspiciant".

Santos (1968: 13/14) continua seu relato abordando a Idade Média, "período durante o qual os juízos de Deus e o duelo, meios de comprovação da verdade então geralmente havidos como insubstituíveis, tornavam supérflua toda e qualquer discussão técnica ou científica sobre os fatos da causa". O retorno às práticas periciais, bem como sua conseqüente evolução ocorrem no Direito Canônico, ao se substituir o "sistema barbaresco das ordálias", então condenado, pela inspeção ocular das pessoas e das coisas, quer fossem realizadas pelo juiz ou por peritos. Nos denominados tempos modernos, a prova pericial toma relevância, pois ficou estabelecido que os juizes não tinham condições de ter conhecimentos sobre todas as coisas. Na Europa de então, especificamente na França, relata Santos (1968) que a Ordenança de Blois, de 1579, definia, no artigo 162, nas questões relativas ao valor das coisas, tal valor fosse estabelecido por peritos e não por testemunhas. Antes dessa ordenança, já as Ordenações Afonsinas de 1446, seguidas pelas Decretais de Gregório IX, regulamentavam a prova pericial de forma ampla. A era das grandes codificações inicia-se com a revolução francesa e a unificação italiana. Aparecem, então, o Código Civil e o Código de Processo Civil, respectivamente em 1804 e 1806, na França, e em 1865, na Itália. Para Santos (1968), "a distinção entre exame judicial e exame pericial se encontra perfeitamente delineada nos códigos modernos, de modo a constituir a perícia, espécie probatória absolutamente distinta das demais, obedecendo a princípios e regras próprias". Segue o autor, estabelecendo a importância da prova pericial, mormente no século XX. E podemos estender estas considerações para o presente século. Assim se expressa o autor, ao referendar a prova pericial: (1968: 21-22)

Outrossim, com o ininterrupto desenvolvimento das ciências e das artes, acentua-se cada vez mais a prática da perícia nas lides forenses, procurando- 
se por meio daquelas e por intermédio dos seus cultores, cientistas e técnicos, aperfeiçoarem-se os métodos de apuração da verdade, tanto nas causas civis como criminais. Peritos passaram a ser chamados não só para a verificação de fatos da causa, para os quais reclamem conhecimentos especiais, como ainda - observa Mittermayer, relativamente ao processo penal - para a demonstração da sinceridade das testemunhas e da confissão, ou para apreciar as faculdades de discernimento do indiciado. A importância da técnica na apuração de certos fatos é de tal monta que - narra Chiovenda - um advogado inglês (John Copley, que foi mais tarde Lord Lyndhorst), a fim de melhor discutir os interesses de um cliente, numa questão sobre patente industrial, trabalhou como aprendiz nas oficinas até chegar a conhecer com perfeição o funcionamento da máquina a respeito da qual se controvertia. Escrevia Lobão, há quase um século: - "não há princípio mais trivial no foro, como ser a vistoria uma prova superlativa, a melhor do mundo e superior a todas as provas". Não difere a qualificação de Pereira e Souza: "é de todas as provas a mais plena; prevalece sobre as outras; porque aquilo que se vê é moralmente mais certo que o que se ouve". Ainda que despidas essas referências dos exageros da linguagem, ainda assim fica bem nítido que desde velhos tempos a perícia era tida na mais alta conta. $\mathrm{Na}$ mesma alta conta havida na tela judiciária contemporânea, e em campo cada vez mais vasto praticada, é, bem por isso, daqueles meios de prova que hão merecido vários e especiais lavores dos juristas brasileiros, aos quais este trabalho se junta como modesta contribuição para maiores e mais aprofundados estudos.

O conceito de prova pericial é estabelecido por Santos (1970: 23-41), no segundo capítulo do Livro $\mathrm{V}$ do seu tratado, em que o autor aborda o princípio da imediatidade e da prova, o exame judicial, a distinção entre exame judicial e exame pericial, a função do exame pericial, a conceituação de perito, a perícia como meio probatório, as definições de perícia e a definição de perícia adotada. Seguindo os caminhos de Bentham, Mittermayer, Malatesta, Gorphe e Döhring, Santos (1970) avoca a verdade como referencial na conceituação de prova, verdade esta que chega ao espírito de quem aprecia, construída na conceituação latina do termo verdade, ou seja, no tempo histórico, calcada nos fatos sobre os quais versa a ação.

A verdade que se alcança através do conhecimento foi compreendida por Garcia Morente (1980: 149), como a "concordância do pensamento com o objeto". Nesta compreensão da verdade, Santos (1968: 23-24) estabelece o fundamento conceitual da prova pericial.

Sob o aspecto objetivo, prova é o meio - pessoa, documento ou coisa - por que a verdade chega ao espírito de quem aprecia; são os meios de demonstração da verdade dos fatos sobre os quais versa a ação. No seu aspecto subjetivo, prova é a própria convicção da verdade dos fatos alegados. Essa prova resulta do exame sereno daquela, isto é, das pessoas que falam, do documento que atesta, das coisas que na própria mudez retêm os fatos. Tanto melhor e mais forte se forma a convicção quanto mais 
diretamente sejam as provas no sentido objetivo examinadas pelo juiz. Nem por outra razão domina no processo moderno o princípio da imediatidade, segundo o qual é exigido contacto direto do juiz não só com as partes e seus advogados como também, e especialmente, com as provas, sejam pessoas, testemunhas ou partes, documentos ou coisas, cujas declarações ou atestações lhe caiba apreciar... E, repita-se, isso lhe impõem à lei e a doutrina como consagração do princípio que reclama o exame direto das provas na formação da convicção.

Santos (1968), neste mesmo capítulo, trata da denominada prova material, que muitas vezes "fala" por si só, ajudando sobremaneira a formar a convicção do juiz de forma peremptória. A prova material seria qualquer materialidade, fenômeno físico ou a própria coisa que atestaria sua veracidade. Para se chegar a esta materialidade, o autor referencia os gestos, a postura, a voz em suas diversas nuances, a grafia, a ortografia e o estilo do examinando, instrumentos do delito, sangue nas vestes, ferimentos corporais, impressões digitais, a mercadoria rejeitada, a construção que ameaça ruir, o cônjuge argüido de impotência coeundi, o cônjuge argüido de impotência concipiendi, a ação de anulação do casamento, pessoas ou coisas como provas materiais, dados que deveriam ser levados à presença do juiz, para que assim se formasse, com maior precisão, a convicção.

Santos (1968), ao escrever sobre a prova judicial, fala daquele tipo de ato praticado pelo juiz, que dispensa a ação pericial propriamente dita. Tratar-se-ia da simples inspeção ocular de pessoas, coisas, locais ou eventos que propiciassem ao magistrado a possibilidade conhecer in loco, a materialidade dos fatos. Ter-se-ia assim o que o Direito, em diversos países, denomina como "acesso judicial, ausgenschein, acesso giudiziario, visita sul luogo, descente sur les lieux, reconocimiento judicial’. Tal prática não é comum em nosso país, onde o mais comum é a prova pericial, determinada pelo juiz. A perícia tem por finalidade a percepção e a apreciação dos fatos, podendo os mesmos ser de tal magnitude, que só os expertos possam percebê-los, daí resultando a ação e a interpretação daqueles dados emanados dos vestígios, que poderiam constituir os indícios de ações que demandassem processo judicial.

Santos (1968: 32) relata que

[...] podem os fatos ser de natureza tal que somente sejam percebidos por técnicos. São - na linguagem de Carnelutti - os chamados fatos de percepção técnica, visto que sua percepção exige qualidades sensoriais especializadas dos observadores, ao lado, geralmente, de conhecimentos científicos ou técnicos capazes de compreendê-los e distingui-los. 
Em toda perícia, seria essencial a verificação, certificação ou comprovação dos fatos, continua o autor, quer para levar as provas até o processo, quer para interpretá-los e torná-los inteligíveis ao juiz. Em seguida, o mesmo autor apresenta extenso relato das definições de perícia e de atos periciais, feitas por autores como Glasson, Cuche, Fraga, Mattirolo e Lessona, para finalmente assim definir: "a perícia consiste no meio pelo qual, no processo, pessoas entendidas e sob compromisso verificam fatos interessantes à causa, transmitindo ao juiz o respectivo parecer" (1968: 32).

Quando se trata do estudo dos pilares da própria estrutura judicial, Miguel Reale, em artigo publicado no jornal "O Estado de São Paulo", diz que "o legislador age como o engenheiro que constrói um prédio segundo um projeto”. No texto de Miguel Reale, encontrase referência importante em relação à dicotomia: visão positiva do Direito versus norma jurídica in fieri.

A ciência do Direito tem muito a ganhar no que se refere à distinção entre o saber tradicional do jurista, a partir da norma jurídica já posta e predeterminada, e como tal é dita positiva, e o saber jurídico em função da norma jurídica in fieri, isto é, como projeto de uma estrutura normativa que quer estabelecer para atender às necessidades de dada situação social e econômica. Foi por volta de 1968 que, em comunicação apresentada ao Congresso Internacional de Filosofia realizado em Viena, me ocorreu a idéia de estudar o direito à luz de uma "teoria dos modelos jurídicos", trabalho este inserto depois em meu livro Estudos de Filosofia e Ciência do Direito, Edição Saraiva, 1978. Observo que não foi por mera coincidência que, no mesmo ano de 1968, publiquei um de meus livros fundamentais, que iria servir de ponto de partida para toda a minha Teoria Geral do Direito. Refirome a O Direito como Experiência, no qual demonstro a necessidade de estudar a realidade jurídica mediante os conceitos de estrutura e de modelo. Passei a ver o Direito como uma "estrutura normativa", ou seja, como um fato ou complexo de fatos interligados isomorficamente por um sistema de regras verticalizado no sentido da realização dos fins ou valores exigidos pela idéia de Justiça, não de maneira abstrata, mas em concreta funcionalidade histórica com a pessoa humana. Daí a noção de "sujeito do Direito" como um ser situado num conjunto de circunstâncias. Ora, é manifesta a diferença entre a visão do Direito como projeção de um quadro de normas positivas, cujo significado cabe interpretar, e a sua compreensão quando se trata de construir "ex novo" um sistema de normas destinado a reger determinado espaço social. Esta segunda visão é a do legislador que quer alcançar determinados objetivos culturais, sociais, científicos, artísticos, etc. agindo como o engenheiro que está construindo um prédio segundo um modelo ou projeto. Há, em suma, uma "engenharia jurídica" em todo "projeto de lei", partindo o legislador dos mandamentos vigentes para implantar algo de novo no ordenamento jurídico. 
Sabe-se que a Medicina Legal é considerada atualmente, em princípio, ciência aplicada, derivada dos diversos conhecimentos emanados das ciências acima referidas e contextualizada em um universo que contempla o homem envolto em problemas legais e sociais.

Há correntes de pensadores que insistem em restringir o campo de ação da Medicina Legal, dizendo que a mesma não é ciência, pois não é individualizada, não teria corpo doutrinário, existiriam unicamente questões médico-legais, que poderiam ser respondidas por especialistas de cada área do conhecimento.

Em diversas situações, os documentos médico-legais emitidos propiciam este tipo de entendimento, pela ausência de linguagem e pensamento próprios da Medicina Legal, pelas contradições textuais neles contidas e pela insuficiente fundamentação científica.

Existem, no entanto, outros pensadores que são adeptos de uma visão ampliada da Medicina Legal. Para estes, existem problemas que são atinentes unicamente a ela e há um grande leque de conhecimentos que seriam apanágio único desta atividade científica.

O perito atua e vive no universo particular de cada indivíduo, de cada exame, de cada perícia, o que sugeriria um paradoxo, ou seja, da impossibilidade de se fazer ciência a partir do individuo como assevera Granger (1994). Neste caso, estar-se-ia no seu entender confundindo ciência e saber técnico. Em algumas situações especificas, o ato médico legal é aplicação de saberes técnicos, em outros é aplicação de conhecimentos científicos e na construção de sua doutrina é ciência, assim o entendemos.

O foco de ação da Medicina Legal transita desde a concepção do ser humano quando, por exemplo, investiga a paternidade e a maternidade, acompanha-o durante a vida e pode chegar a vasculhar, muitos anos depois, a própria sepultura. Amplia-se a área de ação da Medicina Legal na medida em que evoluem os conhecimentos e saberes humanos.

Um amplo leque de definições e sinônimos acompanha a Medicina Legal há muito tempo como exemplificado acima. Para que se possa evidenciar a necessidade de estabelecer o sujeito epistêmico desta ciência, é importante apresentar alguns exemplos desses sinônimos.

França (2008: 3) cita os seguintes sinônimos: Medicina Legalis Forensis (A.Paré), Relationes Medicorum (F. Fidelis), Questiones Medico Legalis (P. Zacchia), Medicina Crítica 
(Amman), Schola Júris Consultorum Medica (Reinesius), Corpus Júris Medica Legale (Valentini), Jurisprudência Médica (Alberti), Antropologia Forense (Hebenstreit), Bioscopia Forense (Meyer), Medicina Legal Judicial (Prunelle), Medicina Pública (Marx), Medicina Forense (Sydney Smith), Medicina Judiciária (Lacassagne). Para o mesmo autor, seria melhor denominá-la de Medicina Política e Social, devido às suas múltiplas intimidades nos relacionamentos sociais e políticos do homem.

O perfil caudatário da Medicina Legal em relação ao Direito está contido em textos de diversos autores, que entendem a Medicina Legal como conjunto de definições e "conceitos", que fundamentados nos pressupostos da Medicina e da Biologia, permitiriam um exercício científico, por assim dizer, da prática judicial. Arbenz (1988: 3) aborda a Medicina Legal como disciplina jurídica quando busca conceituar a mesma:

A Medicina Legal é uma atividade médica que se distingue das demais por
seu objeto e por suas finalidades. A matéria que constitui o seu objeto de
estudo é muito extensa, profunda e variada. Ela sistematiza, reúne num
corpo de doutrina, uma série de conhecimentos que transcendem o campo
estritamente médico. Para atingir os seus objetivos, ela tem necessidade de
congregar todos os conhecimentos que obtém das ciências biológicas e,
eventualmente de outras, como se verá adiante. É a aplicação desses
conhecimentos ao Direito que constitui os seus objetivos. Decorre disso que
a Medicina Legal, sendo de natureza médico-biológica, tem, no entanto,
caráter e espírito jurídico. Nessas condições, não é fácil enunciar uma
definição, expressar o conceito por meio de palavras. Outra não é a causa do
grande número de definições e de denominações, o que, paradoxalmente,
traduz a multiplicidade de interpretações, a meu ver, inadmissível e
desnecessária, porém real.

Outro problema a ser enfrentado é certa tendência de diversas instituições do ensino em nosso país, de considerarem a Medicina Legal como disciplina cujo conhecimento é dispensável, entendendo-se assim, que qualquer profissional da Medicina poderia praticar atos periciais, ou proferir aulas de Medicina Legal, sem os elementos do conhecimento onde se fundamentam esta ciência. Repetindo tendência detectada por Hélio Gomes no século passado. Este autor percebeu que na cidade do Rio de Janeiro, importante desde então, centro cultural e científico, eram naquela ocasião indicados para a prática pericial, pessoas não qualificadas, porém acobertadas por apadrinhamentos políticos (veja-se aqui o termo "político" no pior sentido da acepção do termo, não na visão aristotélica do mesmo). Tal fato podia demonstrar cabalmente a insuficiente compreensão da importância científica da Medicina Legal e sua flagrante importância social, daí derivando graves implicações 
decorrentes de sua má prática. Hélio Gomes (1968: 32) lançou naquela ocasião um libelo contra estas distorções, cujo texto é o seguinte:

No entanto, não basta a um médico ser simplesmente médico para que se julgue apto a realizar perícias. Como não basta a um médico ser simplesmente médico para que faça intervenções cirúrgicas. São indispensáveis estudos mais acurados, treino adequado, apropriação paulatina da técnica da disciplina. Nenhum médico, mesmo eminente, está apto a ser perito pelo só fato de ser médico. São-lhe indispensáveis educação médico-legal, conhecimento da legislação que rege a matéria, noção clara da maneira como deverá responder aos quesitos, prática na redação do laudo. Sem estes conhecimentos puramente médico-legais, toda sua sabedoria será improfícua ou perigosa, a não ser que ele obtenha colaboração de um legista ao trabalho puramente médico de sua especialidade.

Esta sumária "bibliografia consultada" atende aos reclamos desenvolvidos nos demais textos desta Tese, onde se desenvolveram situações e fizemos afirmações como "da necessidade de se desenvolver um conteúdo doutrinário e método apropriado" para o bom exercício da Medicina Legal pelos seus operadores, ou seja, pelos médicos legistas. 


\section{CAPÍTULO II}

\section{CONSIDERAÇÕES SOBRE A DOUTRINA}

Como vimos a Medicina Legal nos seus albores, entendida como arte - arte de fazer relatórios perante a Justiça, esta, representada pelos magistrados ou Conselhos de Justiça, tem início no século XVI. A maioria dos autores cita o Edito della Gran Carta della Vicaria di Napoli, em 1525, como o evento inicial, onde se torna presente a Medicina Legal. O caminho científico, as publicações no âmbito da ciência, aportam no século XVIII, na Alemanha, que por estas circunstâncias é cognominada de "berço da Medicina Legal". Outros eventos foram fundamentais nos primórdios desta Ciência tais como: a Constitutio Criminalis Carolina de 1532, o livro de Ambroise Paré publicado em 1575 cujo título era Des Rapports et de Moyens d'Embaumer les Corps Morts, assim como o trabalho de Fortunato Fidelis de 1602 em Palermo e intitulado De Relatoribus Libri Quator in Quibis ea Omnia quae in Forensibus ae Publicis Causis Medici Preferre Solent Plenissime Traduntur, e ainda, a obra de Paolo Zacchia publicada entre o ano de 1621 e de 1651 em Amsterdã e denominado Quaestiones Medico Legales. Estes eventos já evidenciavam a complexa e relevante ciência ali nascente.

Para Flamínio Fávero, tanto a Medicina Legal quanto a Clínica, são Medicina aplicada, embora a primeira não se restrinja unicamente à Medicina, obtendo subsídios da Biologia e de outras ciências da empiria. Para Genival Veloso de França, é ciência e arte; arte, precipuamente científica, no sentido da techné aristotélica. 
O amplo espectro de atuação dos cultores da Medicina Legal, como vimos no capítulo anterior pode ensejar uma confusão entre conhecimento científico e saberes técnicos, como assinala Gilles Granger (1994). No capítulo introdutório dessa Tese, está referenciado um dos problemas centrais a serem abordados: a Medicina Legal é Arte? Ciência? Ciência aplicada? Os saberes necessários são técnicos ou científicos? Ou ainda, seriam estes saberes, científicos e técnicos ao mesmo tempo, quando se trata das práticas em Medicina Legal?

Gilles Gaston Granger (1994: 14), ao comentar o desenvolvimento das ciências no Século XX, quando faz uma resenha dos principais eventos que aí ocorreram assim se pronuncia:

Esta breve e muito incompleta resenha exige uma primeira observação. Nela constatamos no que diz respeito às ciências físico-químicas e biológicas, uma imbricação dos conhecimentos científicos propriamente ditos e dos conhecimentos técnicos no sentido mais amplo. Não há nenhuma dúvida de que essa associação demonstra o caráter necessariamente aplicado da ciência contemporânea. Gaston Bachelard foi um dos primeiros a ressaltar este aspecto da ciência atual; ele define em exemplos tomados, sobretudo das ciências físico-químicas o que chama de "fenomenotécnicas", construções de novos objetos do conhecimento, em relação direta com as operações de uma técnica. Mas essa associação por mais inevitável e por mais essencial que se tenha tornado tanto para uma quanto para a outra, não deixa, em compensação, de ocultar uma profunda diferença de objetivos entre o pensamento científico e o pensamento técnico.

As práticas médico-legais estão muito mais próximas dos denominados saberes técnicos, definidos por Granger do que daqueles por ele chamados de "saberes científicos". Tal situação deriva substancialmente da amplitude da área de atuação dos operadores da Medicina Legal e da conseqüente especialização, como forma de se dividir o conhecimento e assim facilitar-se o seu labor. França (2008: 7-8) ao considerar os destinos da Medicina Legal assim a classifica:

Levando-se em consideração o enfoque ou a sua destinação, a Medicina Legal pode ser classificada sob os ângulos histórico, profissional, doutrinário e didático. A classificação sob o prisma histórico diz respeito às várias fases evolutivas desta ciência, que a divide em Medicina Legal Pericial, Medicina Legal Legislativa, Medicina Legal Doutrinária e Medicina Legal Filosófica. A Medicina Legal Pericial, também chamada de Medicina Legal Administrativa ou Técnica Pericial Forense ou Medicina Legal Judiciária, é a sua forma mais anterior e está voltada aos interesses legispericiais da administração da justiça. A Medicina Legal Legislativa contribui na elaboração e revisão das leis em que se disciplinam fatos ligados às ciências biológicas e afins. A Medicina Legal Doutrinária, de caráter mais refinado e cultuado por alguns, contribui na discussão dos elementos subsidiários que 
sustentam certos institutos jurídicos onde se reclama conhecimento médico legal. E a Medicina Legal Filosófica, mais recente, discute os assuntos ligados à Ética, à Moral e a Bioética Médica no exercício ou em face do exercício da Medicina. A classificação sob a visão profissional da Medicina Legal está inclinada à forma como se exerce na prática essa atividade. Assim, se divide em Medicina Legal Pericial, Criminalística e Antropologia Médico-Legal, que são exercidas respectivamente pelos Institutos de Medicina Legal, de Criminalística e de Identificação. Levando-se em conta o interesse doutrinário do Direito, naquilo que lhe é mais específico, pode-se dividir a Medicina Legal em Medicina Legal Penal, Medicina Legal Civil, Medicina Legal Canônica, Medicina Legal Trabalhista e Medicina Legal Administrativa. Cada uma dessas partes trata dos diversos ramos do Direito positivo mais estruturados. Sob o ponto de vista didático, a Medicina Legal está dividida em Medicina Legal Geral (Deontologia e Diceologia) e Medicina Legal Especial. Na primeira parte, também chamada de Jurisprudência Médica, estudam-se as obrigações e os deveres (Deontologia) e os direitos dos médicos (Diceologia), particularizando-se nos capítulos sobre Exercício Legal e Ilegal da Medicina, Segredo Médico, Honorários Médicos, Responsabilidade Médica e Ética Médica, assuntos que orientam o médico no exercício regular de sua profissão. A Medicina Legal Especial disciplina-se nos seguintes capítulos: Antropologia médico legal, Traumatologia médico-legal, Sexologia médico legal, Tanatologia médico legal, Toxicologia médico legal, Asfixiologia médico legal, Psicologia médico legal, Psiquiatria médico legal, Criminalística, Criminologia, Infortunística, Genética médico legal e Vitimologia.

Observando-se o extenso leque de interesses da Medicina Legal e acima referenciado por França, que transita entre a episteme e a doxa aristotélicas, temário este que os cultores da Medicina Legal entendem ora como ciência, em outra ocasião como técnica, onde reflexões filosóficas e relações com o universo das denominadas ciências jurídicas formam um conjunto de conhecimentos de extrema importância social, daí o considerar-se relevante um estudo doutrinário sob a égide epistemológica como ora o proposto nesta Tese.

A partir dos ensinamentos e reflexões de Aristóteles, René Descartes, Immanuel Kant, Karl Popper, Gilles Granger e de Jean Piaget, entre outros, enquanto homens de Ciência e Filósofos, esta Tese vai à busca dos elementos doutrinários que possam ancorar "um pensar científico", uma visão "fenomênica adequada", tanto à construção da prova científica, quanto à geração de documentos que a relatem e influam decididamente na ambiência jurídica.

A prova em Medicina Legal é concreta, porém está inserida num contexto de amplitude variável. Esse contexto tem, necessariamente, fundamentos, no que se denomina tecnicamente, de vestígios e indícios. Nossa concepção é a de que a verdadeira prova deve inserir o dado vestígio e o conseqüente indício num todo estruturado formando um sistema e nesse, os elementos estarão necessariamente ligados. Entende-se aqui como necessário: aquilo 
que não pode deixar de ser. Essa seria a prova indubitável, que teria superado o nível do vestígio e do indício em direção a um sistema de conceitos. Fora disso só podem existir as provas com maior ou menor probabilidade de "coincidirem com os fatos", ou seja, com a assim chamada, "verdade", aqui entendida como verdade empírica, aquela coincidente com os fatos.

A grande diferença entre a prova indubitável e a prova com diferentes níveis de probabilidade é curiosa. A primeira, digamos, é “popperiana”, ou seja, falseável, insere-se no âmbito da lógica da pesquisa científica; a segunda aproxima-se do outro extremo da "linha da ciência”, a História, pois está no nível do método histórico: reconstituição dos fatos, busca de restos da ação criminal (vestígios), inquirição, indícios etc., atendendo ao repto clássico da Medicina Legal, ou seja, o visum et repertum, dos albores do século XVI.

A prova indubitável referida acima, carregando em si o conceito de prova científica, constituir-se-ia, a nosso ver, no elo essencial entre a Medicina Legal, o Direito e a Justiça, numa vertente triádica, que atenderia ao proposto por John Rawls (1997: 3-4) quando se manifesta sobre Uma Teoria da Justiça:

\begin{abstract}
A Justiça é a primeira virtude das instituições sociais, como a verdade o é dos sistemas de pensamento. Embora elegante e econômica, uma teoria deve ser rejeitada ou revisada se não é verdadeira; da mesma forma leis e instituições, por mais eficientes e bem organizadas que sejam, devem ser reformadas ou abolidas se são injustas. Cada pessoa possui uma inviolabilidade fundada na Justiça que nem mesmo o bem-estar da sociedade como um todo pode ignorar. Por essa razão, a Justiça nega que a perda da liberdade de alguns se justifique por um bem maior partilhado por outros. Não permite que os sacrifícios impostos a uns poucos tenham menos valor que o total maior das vantagens desfrutadas por muitos. Portanto, numa sociedade justa as liberdades da cidadania igual são consideradas invioláveis; os direitos assegurados pela Justiça não estão sujeitos à negociação política ou ao cálculo de interesses sociais. A única coisa que nos permite aceitar uma teoria errônea é a falta de uma teoria melhor; de forma análoga, uma injustiça é tolerável somente quando é necessária para evitar uma injustiça ainda maior. Sendo virtudes primeiras das atividades humanas, a Verdade e a Justiça são indisponíveis.
\end{abstract}

Assim, a prova, no contexto da ciência que exigiria apenas "saberes científicos" e "técnicos", na reflexão de Granger sobre a vivência da ciência moderna (a mesma prova que também não foge ao epíteto de fenômeno-técnica definido por Gaston Bachelard e citado anteriormente), deve atender a preceitos éticos, como os definidos por França (2008: 18-19), quando estabelece os deveres de conduta do perito: 
Quando da avaliação da responsabilidade profissional em um contestado ato pericial, seja nos Conselhos Profissionais, seja na Justiça Civil ou Criminal, recomenda-se sejam levados em conta os deveres de conduta do acusado. A prática tem demonstrado que isto, além de imprescindível, torna a tarefa mais objetiva e racional. Desta forma, para se caracterizar a responsabilidade do perito nestas atividades, não basta a evidência de um dano ou ilícito, mas que reste demonstrada uma forma de conduta contrária às normas morais e às regras técnicas vigentes e adotadas pela prudência e pelos cuidados habituais, e que o resultado fosse evitado por outro profissional em mesmas condições e circunstâncias. As regras de conduta, argüidas quando de uma avaliação da responsabilidade do perito, são relativas aos seguintes deveres: deveres de informação, deveres de atualização profissional, deveres de abstenção de abusos, deveres de vigilância, de cuidados e de atenção.

$\mathrm{O}$ agir pericial pressupõe, de fato, uma perene atualização, o que inclui o conhecer e usar adequadamente os recursos subsidiários de diagnose, no intuito de bem executar o ato pericial. Trata-se também de ter-se em mente o extremo relevo do referido agir, atendendo-se ao proposto por Rawls em texto acima, quando fala de uma Teoria da Justiça.

Para que se possa fazer uma prática pericial que atenda às denominadas primeiras virtudes das instituições sociais no dizer de Rawls, urge referenciar-se esta prática na ambiência da Ciência, daí a necessidade de se utilizar (sem com isso cair-se no extremo do Utilitarismo como sistema que consiste em reduzir a noção do justo à do útil), dos conhecimentos (sensu lato) oriundos da Filosofia da Ciência e da longa tradição inquiridora e perscrutadora da Medicina Legal.

A Filosofia da Ciência é a área específica da Filosofia que se dedica à reflexão sobre o conhecimento científico e especialmente sobre a possibilidade de seu estabelecimento nas diversas áreas do saber humano. Ao filósofo da ciência biológica caberia o pensar como se ordena ou classificam-se naturalmente os fenômenos, ou seja, não se permitir apenas o agruparem-se os mesmos de forma artificial, mas sim sob a ótica das "classes", em uma visão da "estrutura" e do "movimento" sob "leis fundamentais", que por analogia teriam o mesmo papel que aquele das "leis matemáticas" na Física ou na Geometria. Ernst Mayr, filósofo da ciência e eminente biólogo, recentemente falecido, ao referir-se a "Novos modelos de explicação científica" (2008: 79) assim se pronuncia:

A filosofia da ciência moderna começou em 1948, com um artigo escrito por Carl Hempel e Paul Oppenheim, que seria detalhado por Hempel em 1965. Nesses ensaios, Hempel propôs um novo modelo de explicação científica, que chamou de modelo dedutivo-nomológico (D-N). Esse esquema teve seu apogeu nos anos 1950 e 1960 e também ficou conhecido como "a visão recebida". A idéia por trás da explicação dedutivo-nomológica é a seguinte: 
uma explicação científica é um argumento dedutivo no qual um enunciado que descreva evento a ser explicado é deduzido a partir de uma ou mais leis universais somadas a enunciados sobre fatos particulares (regras de correspondência). De acordo com essa visão, uma teoria científica é um "sistema axiomático dedutivo", cujas premissas são baseadas em uma lei. O modelo D-N original era muito tipológico e determinista, e logo seria modificado para poder lidar com leis probabilísticas ou estatísticas.

Ora, nosso objetivo é justamente refletir sobre a indagação: é possível a Medicina Legal como ciência de acordo com os cânones estabelecidos no decorrer da História das Idéias pela Filosofia da Ciência? Ou seriam esses cânones aplicáveis apenas às ciências físicas? Ou seja, às assim chamadas ciências exatas, porque matematizáveis? Ainda no século XXI estaríamos de acordo com Augusto Comte na sua "classificação das ciências"? Ou o progresso das Ciências Biológicas teriam já demonstrado a possibilidade de uma simbiose entre o "estilo matemático" e o "estilo biológico"? Estaríamos agora em condições de criar modelos abstratos, hipotético-dedutivos, na área do organismo? Modelos esses que obedecendo aos cânones já estabelecidos para as ciências exatas preservassem as características específicas ao organismo vivo? Seria a organização viva compatível com os quadros lógico-matemáticos? Ou seja, deveria a organização viva contentar-se com a descrição ou poderia chegar à dedução? Chegar à dedução seria alcançar a necessidade de conhecer as regras de inferência e escapar do aleatório. Chegar à dedução seria também alcançar o necessário de forma análoga àquela das ciências físicas, (aquilo que não pode deixar de ser), seria escapar do contingente, exatamente o que é definido como "não necessário", criando um tertium (uma terceira possibilidade) específico à organização viva na construção de um argumento legítimo? É o que procuramos responder nessa Tese.

Ora, essas reflexões estão absolutamente ligadas ao Método de observação e consequientemente às conclusões que, no caso da Medicina Legal transformam-se nos Laudos. Poderiam esses laudos, se de acordo com os cânones da Filosofia da Ciência a mais rigorosa, impor sua argumentação à Lógica Jurídica?

Começaremos nosso estudo no âmbito da Filosofia das Ciências pelos enunciados de Aristóteles, filósofo que além de deixar para a posteridade a sua própria obra, sistematizou o pensamento científico de sua época.

Oswaldo Porchat Pereira (2001: 35), em trabalho sobre a ciência e a dialética em Aristóteles, estudo este, centrado, nos Segundos Analíticos, da extensa obra do Estagirita, 
transcreve famosa noção de conhecimento científico, por ele proferida: "Julgamos conhecer cientificamente cada coisa, de modo absoluto e não, à maneira sofística, por acidente, quando julgamos conhecer a causa pela qual a coisa é, que ela é a sua causa e que não pode essa coisa ser de outra maneira". A interpretação deste texto é feita por Porchat Pereira (2001: 36) nos seguintes termos:

Noção que comentadores e autores incansavelmente citaram, repetiram e discutiram através dos séculos, tentando, com maior ou menor sucesso, compreendê-la e explicá-la em todo seu alcance e significado. Por ela entendemos, então, que, em sentido absoluto, só há conhecimento científico de uma coisa quando a conhecemos através do nexo que a une à sua causa, ao mesmo tempo em que apreendemos sua impossibilidade de ser de outra maneira, isto é, sua necessidade. Com efeito, 'uma vez que é impossível ser de outra maneira aquilo de que há ciência, em sentido absoluto, será necessário o que é conhecido segundo a ciência demonstrativa'... 'a ciência é universal e procede por conexões necessárias, e o necessário não pode ser de outra maneira'.

Popper (1972: 27), na abordagem inicial de seu livro "A Lógica da Pesquisa Científica", deixa clara a diferença, entre o campo de trabalho da ciência e da lógica da pesquisa em ciência, estabelece o método a ser buscado nas práticas e reflexões científicas e aponta os caminhos a serem perseguidos pelos cultores da ciência. Escreve ele:

Um cientista seja teórico ou experimental formula enunciados ou sistemas de enunciados e verifica-os um a um. No campo das ciências empíricas, para particularizar, ele formula hipóteses ou sistemas de teorias, e submete-os a teste, confrontando-os com a experiência, através de recursos de observação e experimentação. A tarefa da lógica da pesquisa científica, ou da lógica do conhecimento, é segundo penso, proporcionar uma análise lógica desse procedimento, ou seja, analisar o método das ciências empíricas.

A aplicabilidade de conceitos em uma ciência empírica deriva da vivência do cultor dessa ciência. O conceito de que a ciência é universal está presente tanto em Aristóteles, quanto em Popper. Quando se trata da aplicação de preceitos científicos, através de técnicas especificas, estamos diante da arte de cunho científico no sentido aristotélico do termo. $\mathrm{O}$ operador da Medicina Legal, diante de fato ou fatos, que exigem conhecimento científico, é muitas vezes tomado pela dúvida sobre a objetividade ou não do seu conhecimento científico, e ainda sobre a formação de sua convicção e desta resultante, muitas vezes, deriva a construção do denominado "documento médico legal". Documento este, que deve ser entendido como texto escrito para servir de prova, ou seja, um corolário da prática pericial, 
documento este, que deve ser objetivo e gerar convicção. Popper $(1972: 46,47)$ trata da objetividade científica e da convicção subjetiva, com o seguinte texto:

As palavras "objetivo" e "subjetivo" são termos filosóficos pesados onerados por uma tradição de usos contraditórios e de discussões intermináveis e inconcludentes. O uso que faço dos termos "objetivo" e "subjetivo" não diferem do de Kant. Ele usa a palavra "objetivo" para indicar que o conhecimento científico deve ser justificável, independentemente de capricho pessoal; uma justificação será "objetiva" se puder, em princípio, ser submetida à prova e compreendida por todos. 'Se algo for válido', escreve Kant, 'para todos os que estejam na posse da razão, seus fundamentos serão objetivos e suficientes'. Ora, eu sustento que as teorias científicas nunca são inteiramente justificáveis ou verificáveis, mas que, não obstante, são suscetíveis de se verem submetidas à prova. Direi, consequientemente, que a objetividade dos enunciados científicos reside na circunstância de eles poderem ser intersubjetivamente submetidos a teste. Kant aplica a palavra "subjetivo" a nossos sentimentos de convicção (de variados graus). Saber como surgem esses sentimentos é tarefa da Psicologia. Podem surgir, por exemplo, "de acordo com as leis da associação". Razões objetivas também podem atuar como "causas subjetivas de juízo", na medida em que possamos refletir acerca dessas razões, deixando-nos convencer de seu caráter cogente.

O operador da Medicina Legal, ao relatar o que viu, ou seja, o visum et repertum referenciado acima, o faz muitas vezes de forma automática. Temas como a certeza, opinião e verdade objetiva não permeiam seu raciocínio. Interessa sobremaneira relatar o que "viu", e este ver, limitado pela assertiva de Kant, ao dizer que só vemos e entendemos aquilo do que somos capazes, ou, temos condições de ver e entender. Granger (1960: 184), no capítulo sobre o conhecimento do individual, cita Hegel no livro Fenomenologia, onde este diz: "Langage et travail sont des extériorisations dans lesquelles l'individu ne se conserve plus et ne se posséde plus en lui-même; mais il laisse aller l'interieur tout à fait en dehors de soi et l'abandonne à la merci de quelque chose d'Autre". Tradução livre: Linguagem e trabalho são exteriorizações nas quais o indivíduo não mais se conserva nem mais se possui em si mesmo. Mas ele deixa todo seu interior ir ao exterior e o abandona a mercê de Outro.

Se os conceitos de certeza e verdade estão colocados de forma automática no pensar do perito, automatismo este advindo do seu contato com outras ciências e conhecimentos que podem estar ainda contaminados com crenças e percepções do senso comum, que habitam a estrutura de raciocínio do mesmo, poder-se-á estar diante de um cenário não científico e talvez nem sequer expressão de arte, como conhecimento científico aplicado. 
Granger (1960: 187-188), quando trata da "situação clínica" (termo emprestado das práticas médicas e das práticas em Psicanálise), relata assim o contato do observador com o homem enquanto sujeito concreto e ao mesmo tempo objeto de seu conhecimento:

La situation clinique met dans un rapport immédiat le patient et le thérapeute, l'observé et l'observateur. Il faut entendre par "rapport immédiat" une relation non totalement conceptualisée, enveloppant de façon d'abord confuse de réations de l'un et de l'autre, de telle sorte que la situation qui s'établit ne peut être correctement décrite comme rencontre totalement dissymétrique entre un sujet actif et un objet passif, mais plutôt comme un couple don't les deux partenaires jouent des roles alternés. Il ne peut s'agir alors d'une situation de connaissance speculative, et pas même, originairement, d'une situation de connaissance appliquée. Spontanément, la situation clinique est vécue sur le mode magique et mythique de la communication. Le problème épistémologique capital, c'est d'expliquer comment cette situation peut se developer dans un registre d'authentique connaissance, sans dégénérer en une technique brute d'objectivation mécanique, ni en une pratique incantatoire. L'histoire de la medicine ellemême montrerait diverses péripéties de ce cheminement entre deux écueils: curieux excés "mécanistes" de l'Iatrochemie, et débordements magique du Mesmérisme; rigidité de l'objectivation pasteurienne de la maladie, et tendances aux romanesques des théories psycho-somatiques. L'alternance même des doctrines médicales reflète la double virtualité de l'attitude du praticien. La situation du sociologue, du psycologue, de l'économist, dès qu'ils assument la présence effective d'une réalité humaine bien déterminée, reproduit dans une certaine mésure la même ambiguïté. Un autre trait cependant semble devoir faire rejeter l'analogie: dans l'attitude clinique du médecin predomine assurément la visée du pathologique.

Tradução livre: A situação clínica coloca em relação imediata o paciente e o terapeuta, o observado e o observador. Devemos entender por "relação imediata" uma relação não totalmente conceitualizada, envolvendo primeiro um modo confuso de reações de um e de outro, de tal maneira que a situação que se estabelece não pode ser corretamente descrita como encontro totalmente assimétrico entre um sujeito ativo e um objeto passivo, mas sim como um par em que os dois participantes assumem papéis alternados. Não se trata de partir de uma situação de conhecimento especulativo e nem mesmo, originariamente, de uma situação de conhecimento aplicado. Espontaneamente, a situação clínica é vivida de um modo mágico e mítico na comunicação. O problema epistemológico capital é explicar como essa situação pode se desenvolver em um registro de autêntico conhecimento, sem degenerar-se em uma técnica bruta de objetivação mecânica, nem em uma prática de encantamento. A própria história da medicina mostra diversos trânsitos entre as duas escolas: curioso excesso "mecanicista" da quimiatria, e transbordamentos mágicos do Mesmerismo; rigidez da objetivação pasteuriana da doença, e tendências ao romanesco das teorias psico-somáticas. Alternância que reflete a dupla virtualidade da atitude do praticante. A situação do sociólogo, do psicólogo, do economista, desses que assumem a presença efetiva de uma realidade humana bem determinada, reproduz em certa medida a mesma ambigüidade. Um traço, no entanto faz rejeitarmos a analogia: na atitude clinica do médico predomina a visão do patológico. 


\section{A) Medicina Legal como ciência de uma classe e não como ciência do indivíduo}

A relação do médico legista, com as situações concretas do ato pericial passa muitas vezes por cenário análogo ao descrito acima por Granger. O leque de relações perpassa pela solicitação pericial feita pela autoridade policial por encaminhamento do Ministério Público, pelo acompanhamento do advogado e pela emoção advinda das relações de parentesco do examinando, repercussão na mídia, comoção social em casos de desastres, crimes hediondos, sobretudo praticados contra crianças; entre outras. Dependendo do maior ou menor grau de carga emotiva pode-se estar diante de situação onde o conhecimento científico, o saber técnico e arte retórica de produzir o documento médico legal estariam em parte, prejudicados. Acrescente-se a isso a diversa formação científica de cada um, o tempo de exercício profissional e o interesse genuíno de cada um em relação à Medicina Legal. Associa-se ainda a esses fatos, certo perfil caudatário da Medicina Legal em relação ao Direito, aqui se estabelece então, o caldo de cultura ideal para o não exercício científico da Medicina Legal. A Medicina, e por decorrência a Medicina Legal, estaria fora do caráter universal da ciência prescrito por Aristóteles?

Teria a Medicina Legal, então, o perfil "desviante" definido por Granger como fundo de quadro, o de uma ciência do individual? O médico legista atua sobre fatos concretos, desde antes do nascimento do ser humano, até depois da morte do mesmo, perscruta a patologia mental e física, ainda vasculha os efeitos da violência sobre o corpo humano e os efeitos das diversas energias presentes no planeta sobre o mesmo ser humano, e para tanto, empresta conceitos e práticas de outras ciências além da Medicina.

Para Aristóteles, a ciência deve ter o caráter de universal, no sentido lógico do termo. A Medicina Legal em sua complexidade tem um universo maior que o da própria Medicina Clínica, haja vista que além de englobá-la, absorve os conceitos de outras ciências. Daí se deduz que as características atribuídas à Medicina, nem sempre servem para a Medicina Legal.

Nossa pegunta central: seria a Medicina Legal uma ciência do indivíduo quando o médico legista relata um fato concreto, ou uma circunstância específica, ou estaria ele aplicando conhecimentos científicos adquiridos válidos para uma classe? Granger (1960: 
188/189) quando trata da Medicina Clínica e da relação do médico com o paciente e sua doença, assim se manifesta:

Le patient est perçu et pensé comme malade, et l'on ne saurait sans paradoxe étendre indéfiniment cette perspective. L'originalité épistémologique la plus féconde de la discipline médicale ne tient-elle pas précisément à la dialectique du "cas", à la saisie complexe et contradictoire du singulier et du symptomatique, de l'idiosyncrasie et du symptome? Dialectique théoriquement très confuse, mais concrètement efficace, et dont il faut peutêtre chercher la prise de conscience la plus lucide non dans les textes hippocratiques, mais dans la théorie aristotélicienne de la connaissance. C'est que l'élément pathologique dans la visée du "cas" ne l'est pas, à vrai dire, essentiel, du moins au sens ou l'entend la science du médecin. Il suffit, pour que s'établisse la dialectique du cas, que le fait examiné, que le second terme du couple clinique, soit visé comme "déviant" par rapport à une construction schématique. Et tel nous paraît être pour la science l'aspect positif de l'individuel.

Ttradução livre: O paciente é percebido e pensado como doente, e, sem cair num paradoxo não se poderia estender indefinidamente esta perspectiva. A originalidade epistemológica mais fecunda da disciplina médica não se refere, precisamente, à dialética do "caso", à compreensão complexa e contraditória do singular e do sintomático, da idiossincrasia e do sintoma? Dialética teoricamente muito confusa, mas concretamente eficaz, e na qual seja necessário talvez buscar a uma tomada de consciência, a mais lúcida possível, não nos textos hipocráticos, mas na teoria aristotélica do conhecimento. Acontece que o elemento patológico, na visão do "caso", não é, verdadeiramente, essencial, pelo menos conforme o sentido em que se entende a ciência do médico. É suficiente, para que se estabeleça a dialética do "caso" que o fato examinado, que o segundo termo do par clínico seja visto como "desviante" em relação a uma construção esquemática. E esse nos parece ser para a Ciência, o aspecto positivo do individual.

A aplicação de conhecimentos científicos a cada "caso", em Medicina Legal, é complexa, justamente porque além de preceitos emanados da Medicina, necessita-se consultar outras ciências. O problema a ser enfrentado, portanto, na prática médico-legal, não seria o da singularidade, mas aquele das representações corpóreas do ser humano atingido por diversas classes de energias vulnerantes, ou de situações clínicas peculiares a todo ser humano. Pois, na maioria das vezes, a resposta corpórea, quer seja no ambiente macroscópico ou microscópico tem uma dinâmica comum a todo ser humano, variando apenas nos detalhes, inerentes à herança genética e ao meio em que se situa o indivíduo.

As respostas metabólicas, cicatriciais e fisiológicas variam quanto à intensidade, à extensão temporal e à sua dinâmica, advindo daí aquilo que, na Ciência, poder-se-ia chamar de singularidades. No entanto, estruturalmente, as respostas se assemelham. Estrutura no sentido piagetiano do termo, que contempla as totalidades, as transformações e as auto- 
regulações, sugerindo sistemas fechados que, no entanto, se comunicam e sofrem influências do meio, ou seja, no âmbito de toda organização viva, no âmbito da Biologia.

Para Granger (1960: 189), a figura do "desviante" é rejeitada em toda teoria tradicional do saber, como algo que escapa à ciência. Citando Aristóteles, Granger retoma a doutrina desse filósofo, quando trata da ciência tendo como caráter o universal e necessário e não a significação sofística do acidental:

Aristóte établit à cette effet sa doctrine de l'universel et de l'accident. Dans ce dernier, il n'y a pas de Science, mais dans toute l'épistémologie du Philosophe règne cepandant une sorte de nostalgie de l'individuel. Callias, pour la Science, n'est qu'un homme; mais c'est à lui pourtant que nous avons affaire, et l'un des mouvements profonds de la pensée aristotélicienne conduit à um type suprême de l'être, defini à la fois, comme universel et comme individu singulier par la théologie physique du premier moteur. Conciliation trop évidemment inefficace. La science moderne naissante, qui voudra déchiffrer la nature comme un livre dont les caracteres sont des symboles mathématiques devra radicalement rénoncer à la saisie de l'individuel; plus aristotélecienne en un sens qu'Aristote lui-même, elle será science de l'universel et de l'universel seulement. La théorie des probabilités réintroduit, d'une certaine manière, le deviant, mais en etant seulement que représentatif d'une classe, et non pas comme individuel.

Tradução livre: Aristóteles estabeleceu assim, sua doutrina do universal e do acidental. Neste último, não há ciência, mas em toda epistemologia do Filósofo, reina, no entanto, uma espécie de nostalgia do individual. Callias, para a Ciência, é apenas um homem; mas é a ele, no entanto, que devemos nos reportar, e um dos movimentos profundos do pensamento aristotélico nos conduz a um tipo supremo de ser, definido, por sua vez, como universal e como indivíduo singular pela teologia física do primeiro motor. Conciliação muito claramente ineficaz. A recente ciência moderna, que desejará decifrar a natureza como um livro cujos caracteres são os símbolos matemáticos deverá renunciar radicalmente à compreensão do individual; mais aristotélica que o próprio Aristóteles, ela será ciência do universal e do universal somente. A teoria das probabilidades reintroduz de certa forma, o desviante, mas somente enquanto representativo de uma classe, e não como individual.

Na Medicina Legal Doutrinária, no dizer de Genival Veloso de França (2008), "área de ação de alguns", há necessidade de se estabelecer, qual ou quais elementos têm características individuais e quais têm aquelas dos universais, e nesse caso, concorda-se com Granger (1960: 199), quando diz “Toute pratique s'exerce au contact de l'individuel". A prática médico-legal é apanágio do individual, contudo, nesta atividade, o legista pode encontrar "fenômeno", que altere conceitos, ou obrigue revisão de posições doutrinárias. No entanto, quando se abordam as questões de doutrina, estar-se-ia diante do universal, 
necessariamente. A dicotomia "universal versus acidental", do pensar aristotélico, é vivenciada pelo médico legista no seu cotidiano. Complicada, muitas vezes, pelo "talvez" ou pelo "pode ser", ou seja, pelo condicional, pelo circunstancial, pelos motivos de "força maior" (acidentais), universo este, onde pululam as dúvidas e não as certezas. Certeza esta, entendida como manifestação positiva sem o receio do erro. As certezas não são tão freqüentes como se deseja nos ambientes científicos, antes, as ciências se movem mais nas perguntas do que nas respostas. $\mathrm{O}$ entendimento do individual no âmbito da ciência está restrito aos domínios da aplicação de conceitos científicos, justamente, o território de atuação do legista. Ao se pensar sobre a aplicação de conhecimentos científicos, na atuação do médico legista, deve-se ter em conta certo automatismo, presente no agir do referido técnico. Automatismo este advindo da formação profissional de cada um, tendo como base a Medicina Clínica, a Biologia e ciências afins. Tudo isto, alimentado pela práxis definida na semiologia médica, porém em direção à poiesis, (a práxis é atividade que tem alvo em si mesmo, a poiesis tem por objetivo provocar a existência de algo diverso da própria atividade), anexando-se ainda os fundamentos da legislação, do Direito. O campo de atuação da prática pericial é o individuo. Portanto, é a mesma visão que Aristóteles tem da Medicina no seu tempo, quando diz na Metafísica (A. $\left.981^{\mathrm{a}} .15\right)$ :

Ad agere quidem igitur experientia nihil ab arte differre videtur. Sed expertos magis proficere videmus sine experientia rationem habentibus. Causa autem est quia experientia quidem singularium est cognitio: ars vero universalium. Actus et generationes omnes circa singularia sunt. Non enim medicus sanat hominem nisi secundum accidens: sed Calliam, aut Socratem, aut aliquem sic dictorum, cui esse hominem accidit.

Na tradução de Yebra (1998: 5-6): Pues bien, para la vida práctica, la experiencia no parece ser em nada inferior al arte, sino que incluso tienen más êxito los expertos que los que, sin experiencia, poseen el conocimiento de las cosas singulares, y el arte, de las universales; y todas las acciones y generaciones se refieren a lo singular. No es al hombre, efectivamente, a quien sana el médico, a no ser accidentalmente, sino a Calias o a Sócrates, o a otro de los así llamados, que además, es hombre.

A visão da singularidade, ou melhor, da individualidade do ato médico, referido acima por Aristóteles na clinica médica, deve, a nosso ver, ficar restrita a esta prática e não deve, por extensão, chegar à Medicina Legal.

B) A Medicina Legal entre o acidental, o freqüente aristotélico e o necessário lógicomatemático 
O sujeito do conhecimento na Medicina Legal não se restringe aos atos periciais, antes, busca o universal e demonstrável; ele trata, em nosso entender, do freqüente, aristotélico, (que "como a teoria das probabilidades reintroduz de certa forma, o desviante, mas somente enquanto representativo de uma classe e não como individual", como diz Granger acima) estabelece conjuntos doutrinários e sistemas de referência que tornam possível dizer-se da cientificidade da sua prática.

No entanto, sem que se produza, certa visão ingênua da ciência deve-se retornar ao Estagirita, para se discutir se a ciência gera "hábito" ou "estado" de espírito, ou ainda se ela pode ser estabelecida a partir do "freqüente". Esse conceito aristotélico, enquanto científico, foi introduzido pelo grande helenista Porchat Pereira que o forjou a partir da expressão

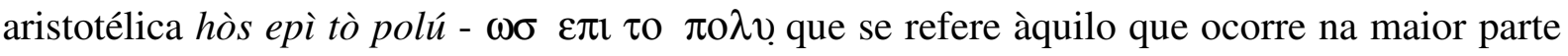
das vezes. O gênio de Aristóteles como que antecipou a teoria das probabilidades aplicáveis às ciências que escapam do necessário e universal, pelo menos num certo momento de sua história, como pensa Granger. Nós diríamos que também se aplica àquelas cuja natureza difere da exatidão lógico-matemática, por exemplo, as ciências biológicas, nas quais o grau de certeza ainda que possa ser muito elevado, não chega ao necessário no sentido daquilo que "não pode deixar de ser".

Porchat Pereira, (2000: 48/ 49) faz a devida referência ao texto de Aristóteles quando trata deste "hábito ou estado" de espírito necessário à vivência científica:

E parece-nos, com efeito, que não poderia ser de outra maneira, pois, a partir do momento em que se reconhece a absoluta anterioridade e primazia do objeto, como o faz Aristóteles, era necessário entender a ciência como atributo do animal humano. E o filosofo é extremamente claro a esse respeito: a ciência está na alma, como em seu sujeito, a ciência é um estado ou hábito e não simples disposição, em virtude de seu caráter duradouro e estável, que se não perde se grande mudança não ocorre, provocada por doença ou fato semelhante. E, ainda segundo as Categorias, não são as diferentes ciências particulares senão qualidades, cuja posse nos faz tais e quais. É, também, como a Ética Nicomaquéia caracteriza a ciência, como um estado ou hábito capaz de demonstrar, e como uma concepção ou juízo que diz respeito aos universais e às coisas que são necessariamente. É de fato a ciência uma espécie de hábito, e é sob esse prisma de suas relações com as outras funções do pensamento, em geral, que a estudará o livro III do tratado Da Alma: o pensar, com efeito, consiste, de um lado, na representação ou imaginação, de outro, na concepção e esta diferencia-se em ciência, prudência e seus contrários. 
Mesmo na situação em que não se tenha conhecimento mais sofisticado, ou que não se consiga atingir a possibilidade de demonstrar cabalmente um fenômeno, algo é essencial, ou seja, o "hábito" ou "estado" de vivenciar pelo menos, a aplicação do conhecimento científico. Se, de fato, não se tem este "hábito", corre-se o risco de não se ter ciência, nem prudência, mas com certeza o contrário, como vaticinou o filósofo.

Quando se fala da Medicina Legal, freqüente, na acepção do português corrente, reflete no universo das práticas periciais, os resultados de eventos originados na violência e infelizmente presentes na sociedade brasileira. Assim para Houaiss, freqüente significa: que se reproduz muitas vezes, que se repete seguidamente, reiterado, continuado, que se faz constante, etc. O labor pericial se enquadra em qualquer um destes significados, quando se olha este mister por esta ótica. Se se levar em conta o que o "site" da Secretaria de Segurança Pública do Estado de São Paulo publica trimestralmente, no que tange aos laudos periciais do Instituto Médico Legal, os seguintes números é um bom exemplo do freqüente no universo fenomênico, ou melhor ainda, no universo das possibilidades de se fazer ciência no sentido concreto do termo. No terceiro trimestre de 2007, foram realizadas 7687 necropsias, 108.480 exames laboratoriais e 154.615 exames periciais, números que têm o condão de estabelecer o "frequiente" para este estudo. Buscando-se comparar o terceiro trimestre de 2007, com o ano de 2006 em Portugal, temos os seguintes números, publicados no "site" do Instituto Nacional de Medicina Legal, daquele país: 26232 exames periciais nas delegações, 48299 exames nos gabinetes Médico Legais das grandes cidades, 2399 exames necroscópicos nas delegações e 4286 exames nos gabinetes Médico-Legais. Outros dados foram obtidos desta instituição e foram os seguintes: 9807 exames de anatomia patológica, 2195 exames psiquiátricos, 11356 exames de genética e biologia forense, e 47816 exames de toxicologia forense ainda no ano de 2006.

Ao se constatar os números do ano de 2006, no mesmo órgão de informação, da Secretaria de Segurança Pública do Estado de São Paulo, e referenciado acima, pode-se utilizar os critérios advindos do "no mais das vezes", pois, segundo Houaiss (2001), às mesmas páginas "não sendo sempre, nem necessariamente, não pode, também, ser de outra maneira". Mais uma vez estamos diante do universo fenomênico, ou seja, do real, como fruto da experiência, onde todo conhecimento se inicia, na visão aristotélica do mundo. Os números como exemplo da realidade, são os seguintes: 30.225 exames necroscópicos, 417.076 exames 
clínicos laboratoriais, 585.545 exames periciais. Pode-se facilmente perceber que ao se levar em consideração os números de todo o país, ter-se-á uma dimensão muito maior, destes eventos, o que corrobora o freqüente, ainda que não no sentido aristotélico, mas quando se trata simplesmente de estudar a prática científica em Medicina Legal.

O que seria ter-se ciência na ótica aristotélica? Ter ciência nesta visão seria o mesmo que "saber", conhecer não unicamente o "que", mas também o "porque" dos fenômenos, do estado das coisas (estado enquanto uma das categorias aristotélicas) entendendo que não se está diante de simples fatos ou fenômenos, mas diante de uma necessidade, unindo-se aí duas fundamentais características, a necessidade do efeito que depende da existência da causa. Depreende-se então, que o estado das coisas, ou ainda, o fenômeno, não é necessário em si mesmo, mas se (e somente se) permanece uma causa suficiente sua, ou seja, aquela na qual o conhecimento forma ou constitui sua ciência. Esta visão da ciência em muito difere daquela vivida em nossos dias, especialmente em certos "espaços científicos" onde predominam as hipóteses e as probabilidades advindas da "indução".

A necessidade, (aqui entendida na visão aristotélica), é determinada pelo Estagirita como parâmetro essencial da ciência, ciência esta que é o conhecimento de coisas que existem sempre, portanto, universais, não significando, no entanto, que todas as coisas, objetos, fenômenos da ciência sejam, para Aristóteles, eternas. Exemplificando através de figuras da Geometria, como fazia o filósofo: o triângulo tem a propriedade de ter a soma dos seus ângulos internos igual a dois retos, esta referida propriedade é universal, ou seja, está contida no "sempre". Aristóteles, no entanto, aceita uma diversidade, que atenua o caráter do necessário, atenuação esta, que não descaracteriza a ciência por ele conceituada, trata o filósofo nos Segundos Analíticos daquelas coisas, fenômenos que existem "quase sempre", ou seja, do freqüente, que continuará a ser discutido abaixo.

Na denominada ciência apodítica, ou ainda, ciência demonstrativa de Aristóteles existem duas características essenciais a causalidade e a necessidade, que são estabelecidas pela demonstração (apódeixis), a isto, o filósofo chamou de silogismo científico. O silogismo sensu lato foi definido por Aristóteles como argumentação, discurso, uso da Razão, ou ainda, forma adequada do pensar, onde a partir de algumas premissas, se chega a algo diverso delas, portanto, à conclusão, que resulta da existência das anteriores. As premissas são, para o filósofo, a causa necessária e suficiente para se chegar à conclusão. 
O silogismo científico existe se as premissas são fundamentadas na aletheia, se são primevas, resultam da ausência de intermediação, portanto, são imediatas e anteriores à conclusão. Deste rigor no falar-se de ciência não foge o filósofo ao referir-se ao freqüente como veremos nos textos abaixo.

Para que se possa iniciar a reflexão, sobre a ciência do "freqüente" em Aristóteles (Metafísica líber XI, 8 1065ª 4-5), vejamos aquilo que estabelece o filósofo, ao comentar o conceito que com este não pode ser confundido, ou seja, o acidental.

Est itaque accidens quod fit quidem, non autem semper neque ex necessitate, neque ut in plus. Quid quidem igitur est accidens, dictum est. Quia autem non este scientia talis, palam. Scientia quidem enim homines semper entis, aut (ut) in plus: accidens autem in neutro horum est.

Na tradução de Yebra (1998: 569) El accidente es, pues, lo que sucede, pero no siempre y por necessidad ni generalmente. Queda pues, dicho qué es el accidente, y que no ciencia de el es indudable. Toda ciencia, em effecto, versa sobre lo que es siempre o generalmente, y el accidente no está en ninguno de estos casos. *Porchat Pereira cria a partir da expressão "sempre e geralmente" (hòs epì to polú- $\omega \sigma \varepsilon \pi \imath \tau 0 \pi \mathrm{o} \lambda v$ ) o conceito filosófico, aristotélico, de freqüente, não presente em qualquer dicionário filosófico.

Porchat Pereira (2000: 178-179), ao comentar a possibilidade, da ciência do freqüente, em Aristóteles, assim se pronuncia:

Vimos Aristóteles condenar como insuficiente, do ponto de vista científico, todo conhecimento que, conhecendo, embora, pertencer um atributo á totalidade de um sujeito, não o apreende segundo a essência e a forma. Se com tanta insistência, porém, repete o filósofo sua exigência de um saber científico rigoroso e recusa qualificar como científico quanto conhecimento não preencha todos aqueles requisitos com tanto empenho enumerados, torna-se-nos imperioso perguntar como haverão de interpretar-se os diversos textos em que nos aparece a ciência, não apenas como um saber necessário e universal, mas também, como conhecimento do que não ocorre senão na maior parte das vezes, isto é, do freqüente? (grifo nosso) Diz-nos, com efeito, a Metafísica que "toda ciência é ou do eterno ou do frequiente". E os mesmos Segundos Analíticos, que encerram a rigorosa doutrina da ciência que vimos estudando, ao expor-nos que não pode haver ciência demonstrativa de quanto provém da sorte, como procedem, senão argumentando com o fato de não ser necessário nem freqüente o que da sorte procede? E acrescentam: "Ora, a demonstração concerne a uma dessas duas coisas". Premissas e conclusão do silogismo científico serão, de fato, umas e outras, ou necessárias ou freqüentes, a conclusão acompanhando a natureza das premissas. $E$ os princípios imediatos de uma demonstração do freqüente serão, igualmente, freqüentes. (grifo nosso) Também o acidente será caracterizado pela Metafísica, não somente por oposição ao necessário, mas também, ao freqüente: é aquilo que, pertencendo a um sujeito, nem lhe pertence por necessidade, entretanto, nem 
na maior parte das vezes. Será um acidente, por exemplo, o frio, durante a canícula, em que o tempo quente e seco é freqüente.

O freqüente de Aristóteles poderia hoje ser entendido como um argumento indutivamente correto, já que é intermediário do absolutamente necessário da dedução e do contingente? A proposta de Hempel, (Karl Gustav: 1905/1997) Matemático e Filósofo, que pertencendo ao círculo de Berlim, também freqüentou o círculo de Viena, foi a de que: "um argumento é indutivamente correto se (e somente se) as seguintes duas condições estiverem satisfeitas: 1- o argumento não é dedutivamente legitimo; 2- a probabilidade de a conclusão ser verdadeira é maior do que a probabilidade de ser verdadeira qualquer outra conclusão "rival".

Em nosso entendimento, a proposta de Hempel se aplica perfeitamente ao que se pode denominar de "proposições particulares", pois estas são inferidas dos fenômenos e em seguida seriam generalizadas por indução, em situações peculiares, ou seja, seria possível em uma "categoria unitária".

Mas, não contemplaria o "freqüente aristotélico", que explica o universo da ciência quando não possível o "universal" e o "necessário", fugindo assim do "acidente", onde não se faz ciência na ambiência filosófica do Estagirita.

$\mathrm{Na}$ esteira do argumento "indutivamente correto" aludido acima para o termo "freqüente" sob a ótica aristotélica, a simples repetição de eventos de causas externas, como acontece ao ser humano ao ser atingido por energias vulnerantes de diversas naturezas, pode revelar respostas biológicas que além de identificarem a origem da energia, pode também demonstrar que tais respostas são comuns a todo ser humano, ou seja, estar-se-ia diante de respostas que se podem atribuir a "classes", como preconizou Granger e não simplesmente a indivíduos. Ora, se no universo das "classes" estamos diante de ambiência diversa das "coisas particulares", já que naquelas usa-se argumentação fundada no "universal" e no "necessário", [portanto, a partir da dedução], nestas, [proposições particulares] usa-se a indução como referido por Hempel em texto acima, ou seja, atendendo-se a situações peculiares onde a dedução não é possível ainda que a probabilidade da conclusão ser verdadeira seja maior que outra conclusão rival. Tome-se aqui o cuidado de não gerar antinomias, como as referidas por Kant na Crítica da Razão Pura ao tratar do segundo grande problema da metafísica, ou seja, o problema do universo. Concluindo, no caso das "classes" deve-se usar a dedução e não 
a indução como sugeriu Hempel, mesmo tratando-se do "freqüente aristotélico" e não do necessário lógico-matemático.

Os agentes vulnerantes ao agirem sobre organizações biológicas estabelecidas, definidas, cuja identidade genética é definitiva (por exemplo, o ser humano), ou seja, o homo sapiens, ou também, sobre outras estruturas orgânicas definidas, produzem lesões que são comuns às classes respectivas, lesões estas que podem ser classificadas e assim, originar enunciados, inferências e muitas vezes implicações, entendendo-se o termo como implicação lógica, sob a ótica piagetiana que apreciaremos mais tarde.

A nossa indagação é: o enunciado acima poderia ser a "ponte" que nos conduziria da tão criticada, refutada e discutível "ciência do individual", para a ciência das classes e, portanto para a ciência de um universal biológico, como acreditamos nós, nessa Tese?

Para que se possa responder de forma adequada às questões acima, teremos que estabelecer os sistemas de conceitos que a Medicina Legal deve possuir, no intuito de realmente se posicionar como ciência, e não, unicamente, como conhecimento científico aplicado. Tarefa difícil, mas, entendemos que é objetivo a ser aqui perseguido, devido à sua evidente relevância.

O “freqüente aristotélico", para que possa ser entendido como uma possibilidade de se fazer ciência, deve atender a critérios bem definidos, sob pena de ser confundido com o acidental, onde efetivamente não se pode fazê-la. Quais foram os critérios que o filósofo estabeleceu para identificar o acidental e o freqüente? Porchat Pereira (2000: páginas 179 a 184), interpretando o pensar aristotélico diz:

Natural é, pois, que nos ocorra perguntar como pode a teoria aristotélica da ciência, sem incorrer em contradição, reservar um lugar para o freqüente, mediante o que, a primeira vista, se configura como uma estranha concessão ao mundo da contingência? Pois o que é "no mais das vezes" (hos epì tò polú), não sendo sempre nem necessariamente, não pode, também, ser de outra maneira?

Se o freqüente fosse entendido na forma acima, equivalente a acidental, seria no pensar do Estagirita, doxa e não episteme, ou seja, opinião e não ciência. Compreende-se então, que o critério de necessário deve estar presente ao se falar do freqüente aristotélico, para que não se confunda com o acidente, ao se pretender fazer ciência. Mas como? Explica Porchat Pereira: 
Compreenderemos, por certo, sem dificuldade, que a noção de freqüente vem permitir ao conhecimento físico de nosso mundo sublunar transformarse em ciência, se recordamos a polêmica aristotélica contra os que postulam uma necessidade absoluta para os eventos naturais, sua teoria do acaso natural, sua constante doutrina de que 'todas as coisas que se produzem naturalmente produzem-se ou sempre da mesma maneira ou na maior parte das vezes'.

Começa a ficar claro, que o acidental e o freqüente, na ausência dos critérios do universal e do necessário, se alternam na explicação do universo da experiência, especialmente nas ciências que se fundamentam na empiria. Prossegue o texto de Porchat Pereira, com uma referência ao possível, que em nosso entendimento fundamenta o essencial da ciência do freqüente:

Se, num certo sentido, portanto, é correto dizer que o freqüente, pelo fato, mesmo, de não ser necessário, é somente um possível, não diremos no mesmo sentido em que o dizemos dos eventos acidentais, porque a matéria é responsável. Distinção de sentidos que se impõe e que os Primeiros Analíticos nos propõem explicitamente, ao mostrar-nos que se diz ser possível em duas acepções, o literalmente possível designando, segundo a primeira delas, o que se dá na maior parte das vezes, ao falhar o necessário, como, para o homem, o encanecer, o crescer, ou o deperecer e, em geral, o que pertence naturalmente a uma coisa; e, num segundo sentido, designando o indeterminado, o que é capaz de ser tanto assim como não assim, como, por exemplo, para um animal, o caminhar ou o haver um terremoto, quando caminha, e, em geral o que provém do acaso, não sendo mais natural que tal fato ocorra e não, o seu contrário. E acrescenta o texto que não há ciência e silogismo demonstrativo dos possíveis indeterminados, dada à instabilidade do termo médio, enquanto os há dos possíveis naturais, sobre que se produzem argumentos e pesquisas. Aos olhos de Aristóteles, não se confunde o freqüente com o contingente.

O texto acima, da lavra de Porchat Pereira, ao propor uma leitura dos Segundos Analíticos de Aristóteles, quando se trata do freqüente e do possível e concluir que "não há ciência e silogismo demonstrativo dos possíveis indeterminados, dada à instabilidade do termo médio, enquanto os há dos possíveis naturais, sobre que se produzem argumentos e pesquisas", delimita, em nosso entendimento, o universo do agir pericial em Medicina Legal, universo este, onde as ações das energias vulnerantes predominam como elementos lesivos ao corpo humano exposto a aquelas energias.

Os Professores Flamínio Fávero e Genival Veloso de França adotam como classificação das energias vulnerantes, aquela estabelecida por Borri. Estas energias estão assim definidas: mecânicas, físicas, químicas, físico-químicas, bioquímicas, biodinâmicas e 
mistas. Além dos autores acima referenciados, a maioria dos estudiosos no tema trauma em Medicina Legal, resume estas sete energias nas quatro primeiras.

Com o intuito de introduzir a questão do freqüente e da classe em ciência, procurando demonstrar a presença destas categorias na Medicina Legal, colocamos nessa Tese, os fundamentos da traumatologia estudados nesta ciência.

Para França (2008), a traumatologia aborda as lesões e estados patológicos, produzidos pelas energias vulnerantes referenciadas acima, que atingem o corpo humano, tanto nos aspectos imediatos e mediatos do diagnóstico e prognóstico, quanto nas implicações jurídicas e socioeconômicas, decorrentes daquelas energias. A presença do ser humano na vida social e no meio ambiente submete de forma comum a qualquer um deles, sob o ponto de vista biológico, às exposições àquelas energias, e as representações corpóreas, das ações traumáticas são expressões ou constituem-se no que se denomina classe em ciência.

O enunciado necessita de demonstração na visão aristotélica de ciência. Popper, ao se referir aos enunciados, classificou-os em universais e existenciais. Utilizando os fundamentos da Lógica clássica, ele estabelece que a negação da modalidade de um destes enunciados, equivale à confirmação do outro. O conhecimento estabelecido sobre as ações decorrentes das energias vulnerantes servem de elemento demonstrativo para o que se quer provar. Poder-seia também submeter tal conhecimento ao crivo do pensar popperiano em relação aos enunciados?

As características de cada um dos enunciados, universais ou existenciais, na visão de Popper sobre o tema, pela sua logicidade e possibilidade de falseamento, conferem cientificidade à proposta da noção de classe para caracterizar ciência em Medicina Legal, (diferenciando-a da própria Medicina em Geral, já conceituada como ciência do indivíduo pela Filosofia das Ciências) como pretendemos nós, nessa Tese. Popper (1972: 73) assim se manifesta sobre os enunciados:

Enunciados estritos ou puros, sejam universais, sejam existenciais, não sofrem restrições quanto a espaço e tempo. Não se referem a uma região individual, limitada, espaço-temporal. Essa a razão por que enunciados estritamente existenciais não são falseáveis. Não podemos investigar $o$ mundo inteiro a fim de determinar que algo não existe, nunca existiu e nunca existirá. Precisamente pela mesma razão, os enunciados estritamente universais não são verificáveis. Não podemos investigar o mundo inteiro para ter certeza de que nada existe proibido pela lei. Contudo, ambas as 
espécies de enunciados estritos - estritamente existenciais e estritamente universais - são, em princípio, empiricamente decisíveis. Decisíveis, porém, num sentido apenas: unilateralmente decisiveis. Comprovado que algo existe aqui ou ali, um enunciado existencial pode, por esse meio, ser verificado, do mesmo modo que um enunciado universal pode ser falseado. da Física:

As energias denominadas mecânicas são representadas pela seguinte fórmula, advinda

$$
\mathrm{F}=1 / 2 m v^{2}
$$

onde $(\mathrm{F})$ representa a força de impacto, $(\mathrm{m})$ representa a massa e (v) representa velocidade.

Ao analisar-se o corpo humano, vivo ou não, submetido à ação da energia mecânica, deve-se levar em consideração, tanto a força de impacto, resultante da equação acima, quanto à representação corpórea da mesma. A abordagem pura e simples advinda dos conhecimentos emanados da Física leva conseqüentemente ao conceito de ciência aplicada, ou ao conceito de conhecimento fenômeno-técnico, estabelecido por Gaston Bachelard e citado acima por Granger. No entanto, a representação corpórea da ação energética, que é comum a todo ser humano, nas mesmas condições de exposição a aquela energia, caracteriza a classe, no sentido estabelecido por Granger, ao tratar do conceito de ciência. Para França (2008:75), as energias mecânicas agem de modo especial sobre o corpo humano:

As energias de ordem mecânica são aquelas capazes de modificar o estado de repouso ou de movimento de um corpo, produzindo lesões em parte ou no todo. Os meios mecânicos causadores do dano vão desde as armas propriamente ditas (punhais, revólveres, soqueiras), armas eventuais (facas, navalha, foice, facão, machado), armas naturais (punhos, pés, dentes), até os mais diversos meios imagináveis (máquinas, animais, veículos, quedas, explosões, precipitações). As lesões produzidas por ação mecânica podem ter suas repercussões externa ou internamente. Podem ter como resultado o impacto de um objeto em movimento contra o corpo humano parado (meio ativo), ou o instrumento encontrar-se imóvel e o corpo em movimento (meio passivo), ou, finalmente os dois se acharem em movimento, indo um contra o outro (ação mista). Esses meios atuam por pressão, percussão, tração, torção, compressão, descompressão, explosão, deslizamento e contrachoque. De conformidade com as características que imprimem às lesões, os meios mecânicos classificam-se em: perfurantes; cortantes; contundentes; pérfurocortantes; pérfuro-contundentes; corto-contundentes. E, por sua vez, produzem, respectivamente, feridas puntiformes, cortantes, contusas, pérfuro-cortantes, pérfuro-contusas e corto-contusas.

As características corpóreas das lesões resultantes de ações mecânicas são peculiares, regidas pela equação acima citada, advinda da Física; são comuns a todos os seres humanos, 
variando devido à intensidade do impacto, ainda apresentando variações de acordo com a região atingida, levando-se em consideração se o corpo atingido está vivo ou morto, pois, estando morto, apresenta outras características, também comuns a este estado. Cada grupo de agentes vulnerantes apresenta possibilidades de ações e respectivas representações corpóreas. No entanto, deve-se levar em conta que, no âmbito da Medicina Legal, raramente o perito tem contato direto com os agentes das lesões; antes, tem contato direto com os efeitos daquelas ações. Desta forma, é o perito, através do estudo das áreas lesadas, quem estabelece qual o agente responsável por aquela ou aquelas lesões. Pode-se dizer que toda ação produzida por agente mecânico é identificada pela lesão produzida no corpo humano. Representa-se esta proposição última da seguinte forma:

$$
(\forall x \in \mathrm{A})(\mathrm{p}(\mathrm{x}))
$$

Essa representação da lógica matemática significa que é possível usar-se o quantificador universal acima exemplificado como forma abreviada da sentença aludida no final do parágrafo anterior.

Immanuel Kant (1994: 49), assim se pronuncia ao considerar um problema de grande complexidade:

\footnotetext{
Muito se ganha já quando se pode submeter uma multiplicidade de investigações à fórmula de um único problema, pois assim se facilita, não só nosso próprio trabalho, na medida em que o determinamos rigorosamente, mas também se torna mais fácil a quantos pretendam examinar se o realizamos ou não satisfatoriamente.
}

Ao se referenciar às lesões produzidas por agente perfurante, como forma de exemplificar a denominada classe, no mister da ciência em Medicina Legal, observa-se a existência de achados comuns ao corpo humano, passíveis de classificação. Estas lesões assim se caracterizam: tem diâmetro transverso reduzido, ou seja, a representação desta lesão na superfície é exígua, podendo ser imperceptível, predomina largamente a profundidade sobre a extensão, não apresenta gravidade na superfície corporal; no entanto, no interior do corpo é freqüente a gravidade destas lesões, por atingirem órgãos internos. Outro fato também observado em todas estas lesões nos seres vivos é que o diâmetro da lesão é menor do que o diâmetro do agente, devido à elasticidade e retratilidade dos tecidos. Tal quadro anatômico e funcional destas lesões é comum ao corpo humano em vida. 
Dando sequiência à demonstração da existência da classe, no sentido estabelecido por Granger, ao estudarem-se as lesões produzidas por ação cortante, também se observa a mesma regularidade dos sinais comuns ao corpo humano atingido por esta ação vulnerante. As feridas resultantes de ação cortante têm as seguintes características: bordas regulares que se cooptam facilmente, fundo de lesão regular, formato linear, hemorragia abundante, ausência de contusões no entorno da ferida, extensão que predomina sobre a profundidade, cauda de escoriação voltada para o termino da lesão, região central da ferida mais profunda que as extremidades, bordas da ferida afastadas, início da lesão mais profundo que o término. Todos estes sinais não atendem ao critério da individualidade ou do acidental, Antes, se enquadram naquilo que Aristóteles estabeleceu como freqüente e Granger definiu como classe em ciência. Dir-se-á ainda, com Piaget (1966: 451) "É preciso distinguir o objeto enquanto objeto, significado pela imagem e o objeto enquanto classe unitária, caracterizado (mas não significado) pelo conceito".

Em Medicina Legal Doutrinária, "área de atuação de alguns”, como já citado acima, segundo Genival Veloso de França, cabe em nosso entendimento, dizer sobre a possibilidade da "classe unitária" explicada acima por Piaget, no âmbito da práxis pericial. Existem e existirão sempre novos instrumentos que, embora não usados contra o corpo humano, ao serem usados pela primeira vez, criem ab initio uma classe unitária de lesões corporais, que migrará necessariamente para o conceito de classe em ciência tanto na visão de Granger quanto na ótica de Popper.

Os sinais corpóreos das ações de energias vulnerantes podem ser traduzidos por enunciados existenciais que, segundo Popper, não são verificáveis, por terem a condição do "concreto" e a explicação do mesmo teria fundamento no "princípio da causalidade", que Popper diz não só rejeitá-lo, mas excluí-lo da esfera da ciência, dando-o por "metafísico" (claro está que Popper assim se manifesta por usar o "princípio da causalidade" de acordo com os seus próprios.). As teorias científicas, pelo contrário, segundo esse autor, são expressas por enunciados universais que, em diversas situações, fundamentaram-se inicialmente nos fenômenos, ou seja, em eventos singulares, normalmente traduzidos por enunciados existenciais. A saída para o aparente paradoxo encontra-se no caráter de ser o enunciado "decisível” ou não, segundo Popper. Estabelecido que um enunciado pudesse ser empiricamente "decisível”, e o sendo, deve sê-lo no sentido unilateral, propiciando que o 
enunciado existencial seja verificável e o universal falseado, observa-se que as respostas corpóreas do ser humano, às ações de energias vulnerantes, podem ser tanto expressas por enunciados existenciais no caso concreto e, portanto singular, quanto expressas por enunciados universais, quando tratar-se de formulações teoréticas, que expliquem e fundamentem o universo pesquisado.

A complexidade do diagnóstico em Medicina Legal perpassa diversas vezes, pela necessidade de isolar-se a informação e decompô-la, para que se atenda a um critério de logicidade inerente à prática científica. Em alguns casos, apresentam-se ao perito, situações peculiares, como a presença da vítima com o possível agente causador do dano. À guisa de exemplo: a vítima tem uma lesão de características de ação vulnerante contusa, e é apontado como agente uma faca, que até mesmo o senso comum identifica como agente cortante. $\mathrm{O}$ aparente paradoxo é resolvido com facilidade, se o perito observar atentamente a lesão. A ferida contusa apresenta bordas irregulares, equimosadas e escoriadas, tem fundo de lesão irregular, apresenta pouco sangramento, bordas da lesão que não se cooptam, necessitando freqüentemente de ajustes cirúrgicos. Se a faca fosse um agente cortante unicamente, estaria estabelecido o paradoxo, no entanto, um mesmo instrumento pode ter diversas ações danosas. Neste caso, o referido instrumento, se usado através do cabo, tem ação contundente, se usado através da lamina tem ação cortante, se usado através da ponta tem ação pérfuro-cortante. Esta situação hipotética corrobora o afirmado acima, a identificação do agente vulnerante é feita através da representação corpórea da lesão.

Quando o agente vulnerante é de origem física, como o calor, o frio, a eletricidade, a radioatividade, a pressão atmosférica, o som ou a luz, constata-se da mesma forma, que as lesões são comuns ao corpo humano em geral, não a um indivíduo em especial. Existindo classificações destas lesões há longo tempo, a demonstração das mesmas corroboram o afirmado acima. Deve-se ressaltar que existem variações das representações corpóreas destas lesões, decorrentes da intensidade do agente, da área corpórea atingida, de eventuais artefatos protetores usados pelas vítimas. Contudo, nas mesmas condições, as mesmas ações produzem as mesmas representações no corpo humano, podendo-se, inclusive, classificá-las. Os documentos médico-legais tipificam as lesões, com enunciados do tipo: vítima apresenta queimadura de $2^{\circ}$ grau no tórax atingindo $80 \%$ daquela área, vítima apresenta geladura do $4^{\circ}$ grau nos pés (pés de trincheira), vítima apresenta carbonização corpórea, vítima apresenta 
lesão arboriforme de Lichtenberg produzida por fulguração decorrente de energia elétrica natural, vítima apresenta hemicorporectomia produzida por corrente elétrica de alta voltagem, vítima apresenta radio dermites do $3^{\circ}$ grau, ou ainda, surdez permanente bilateral decorrente de exposição contínua a agente sonoro de intensidade superior a 90 decibéis.

Os enunciados acima podem ser entendidos como individuais, quando se identificam as vítimas pelo uso dos signos (nomes) pelos quais são conhecidos. No entanto, quando se trata de referenciar o agente vulnerante e a representação corpórea subseqüente, o enunciado é universal. O caráter de decisível, atribuído ao enunciado segundo a doutrina popperiana, possibilita a verificação ou a prova científica no enunciado existencial, quando se estabelece o nexo causal e a conseqüente demonstração, no sentido aristotélico do termo, da sincronia entre aquele agente determinado e a lesão. O caráter universal do enunciado, tendo como fundo de quadro o decisível, é estabelecido quando se pode falsear a afirmação, usando-se as equações da lógica matemática ou da lógica clássica pode-se demonstrar pelo processo hipotético dedutivo, a confirmação e a possibilidade de falseamento do enunciado, levando-se em consideração, que o falseamento, é para Popper, critério de demarcação para se definir uma ciência como empírica.

Se em determinado ato pericial, portanto, num processo de aplicação de conhecimento específico, o perito encontra, por exemplo: paciente apresentando ferida circular, de bordas invaginadas, com orlas de contusão e de enxugo, a análise do material contido no túnel produzido pelo agente vulnerante apresenta resquícios de pólvora e restos metálicos oxidados e ainda se encontra um artefato metálico distorcido e com impressões lineares cravadas em seu corpo, no trajeto da lesão, só podemos verificar e consequientemente provar que a vítima, sofreu agressão por projétil de arma de fogo, que o atirador estava em posição frontal à vítima (devido ao aspecto circular da lesão) e ainda que a arma tivesse cano raiado e não liso. Em tal situação ainda pode-se dar a conhecer o calibre da referida arma, pelo exame do referido projétil. Esta se pode dizer, é situação típica, que pode ser representada por enunciado existencial, ou ainda singular, pois trata de caso concreto. Nesta mesma situação, pode-se dizer que existem neste evento os elementos do necessário e do possível, que caracterizam a ciência do freqüente em Aristóteles e que acreditamos, caracterizará, para nós, o "estilo biológico" de ciência. 
Analisando-se o parágrafo anterior, percebe-se que o caso concreto, nele contido, leva ao enunciado existencial, ou seja, existem naquela situação, características de um conjunto não vazio (sinais concretos de uma realidade), que pode ser representado, conceitualmente, pela seguinte representação da lógica matemática:

$$
(\exists \mathrm{x} \in \mathrm{A})(\mathrm{p}(\mathrm{x}))
$$

França (2008: 103), quando trata das lesões produzidas por projeteis de alta energia, assim se manifesta:

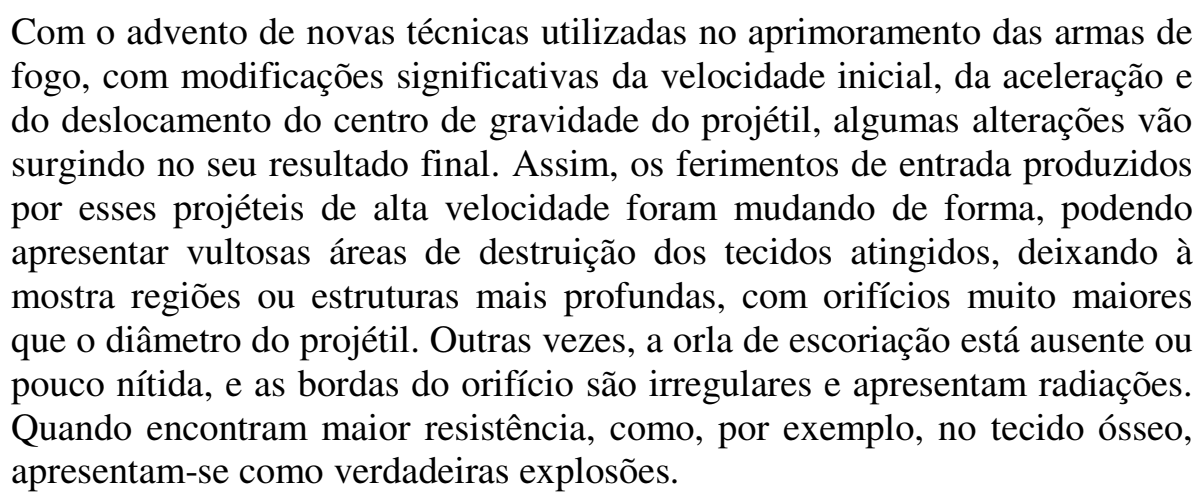

Quando se apresenta ao perito, situação análoga ao descrito acima, considerando-se como fundo de quadro que, regra geral, o perito não tem acesso ao agente vulnerante, apresentando-se perante o mesmo unicamente o corpo para ser examinado, que apresenta lesões semelhantes ao acima referenciado, como se enunciar tal situação?

Algumas questões são imediatamente impostas a casos como este: qual o agente vulnerante? Como se podem classificar as referidas lesões?

Via de regra, o estabelecimento do agente vulnerante é feito de forma imediata, ou seja, resulta da primeira visão do evento (imediato na visão do perito, ou seja, sob a ótica prática do agir pericial, não na visão epistemológica do termo, ou seja, sem mediação). Em situações como esta isto não é possível, torna-se necessário o estudo da situação como um todo e, a partir daí, o agente vulnerante será identificado de forma mediata.

A classificação das lesões dependerá de verificações subseqüientes, que após certo período de estudo, onde estratégias indutivas (tanto no sentido clássico, ou seja, do particular para o geral, quanto no sentido do particular para outros particulares, ou seja, no sentido da 
transdução) ab initio, e dedutivas (do geral para o particular, ou seja, quando se deduz de premissas, a conclusão) a posteriori, possibilitarão a referida classificação.

A demonstração e conseqüente construção do documento que representará eventos deste tipo constituem um sistema de enunciados, como forma demonstrativa do mesmo, pois, outros eventos, com agentes vulnerantes diversos, podem simular situações análogas as acima referenciadas.

$\mathrm{Na}$ atualidade, onde se vivem incertezas e a violência atinge níveis insuportáveis, o ser humano é vítima de ações vulnerantes no cotidiano que antes só eram passíveis de acontecer nos campos de batalha. Um bom exemplo disso é o uso nas grandes cidades do país, pelos agentes criminosos, de armas com projéteis de alta energia. As lesões advindas dos impactos destes projéteis sobre o corpo humano, da mesma forma que nas outras ações vulnerantes, não se constituem em fatos peculiares a cada pessoa, constituem isto sim, lesões comuns a todo corpo humano, portanto, à classe dos seres humanos.

França (2008: 103) conclui o estudo da balística de alta energia da seguinte forma:

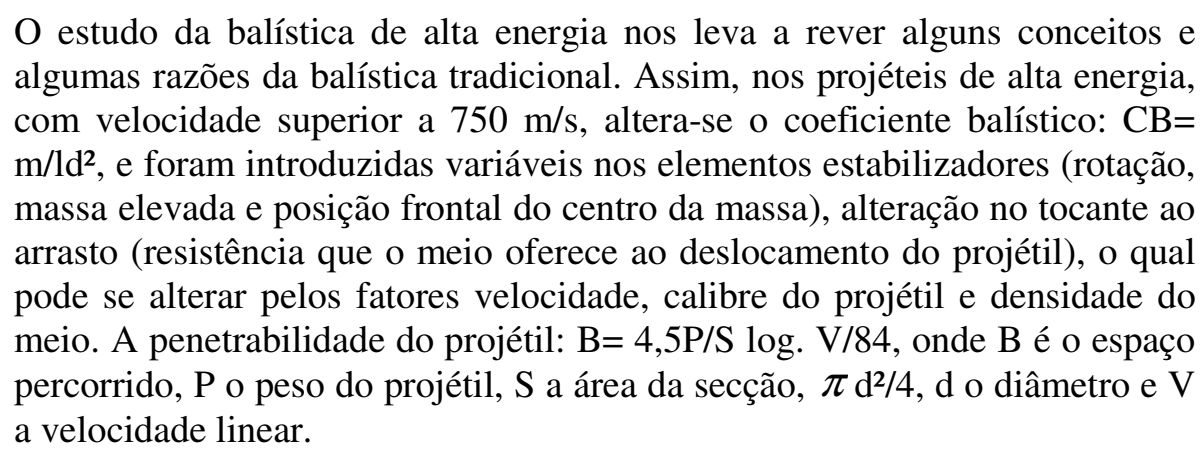

Na medida em que se analisam os aspectos teóricos, mas com raízes na experiência, no examinar estas lesões e ainda nos conhecimentos da física inerente à energia mecânica, devese ter em mente que outras características se apresentam, ou seja, a ação das ondas pressóricas e as ondas de choque que acompanham necessariamente tais projéteis, atividades ondulatórias estas que se superpõem e que produzem lesões de grande envergadura. Além das cavitações de grande volume que também se apresentam nestas lesões.

Quando se está diante de um sistema de enunciados, tem-se um universo teorético que pode ser submetido ao falseamento, como elemento de demarcação de ciência empírica, na visão de Popper e que exige, portanto, uma investigação lógica da falseabilidade, onde ele 
estabelece que existam diferenças entre a falseabilidade e a falsificação, onde aquela seria “um critério aplicável ao caráter empírico de um sistema de enunciados”. (Popper, 1972: 91).

Nosso entendimento sobre classe, como base para uma ciência em Medicina Legal, concorda com o estabelecido por Popper (1972: 68), quando escreve:

Não há dúvida de que aprendemos o uso de certas palavras universais, ou seja, sua aplicação a indivíduos, por meio de gestos e recursos similares. A base lógica de aplicações desse tipo está em que os conceitos individuais podem ser conceitos não apenas de elementos, mas também de classes, e está em que podem representar conceitos universais não apenas numa relação correspondente à de um elemento para uma classe, mas ainda numa relação correspondente à de uma subclasse para uma classe. Exemplificando, meu cão Lux não é apenas um elemento da classe dos cães vienenses. O que é um conceito individual, mas é ainda, um elemento da classe universal dos mamíferos, o que é um conceito universal. Os cães vienenses, por sua vez, não são apenas uma subclasse da classe (individual) dos cães austríacos, mas também uma subclasse da classe (universal) dos mamíferos.

Em seqüência, ao discutido acima sobre classe, entende-se por essencial, explicitar qual significado deve-se seguir nesta Tese, para o uso desta palavra Usar-se-á, aquele definido por André Lalande (1999: 165), quando escreve:

CLASSE: D. Klasse; E. Class; F. Classe; I. Classe. Na Lógica: conjunto de objetos definido pelo fato de esses objetos possuírem todos, e só eles, uma ou várias características comuns. Representa-se na Lógica simbólica pela abreviatura Cls. (Peano, Formulário de lógica matemática, § 2). Termo geral que designa a idéia segundo a qual o gênero e a espécie são os casos particulares.

Em diversas situações, o perito se encontra diante de evento que, pela sua peculiaridade, poderia impeli-lo a graves equívocos. Existem, existiram e existirão eventos que sugerem algo e que o estudo posterior revelou ser outra coisa ou ser outra a causa suposta ou ser outra a abordagem a ser definida e consumada.

À guisa de exemplo, nas regiões do país onde estão presentes reservatórios de água como represas, açudes, lagos, lagoas, rios, ou ainda, na costa marítima, é freqüente a figura do afogamento. Desta forma, o "encontro" (termo este usado no jargão policial) de corpos à superfície da água ensejam de forma imediata, o "diagnóstico" de afogamento. No entanto, na prática pericial, a regra é a de não se estabelecer diagnóstico, sem o devido estudo, ou seja, deve-se seguir o pensamento kantiano quando diz que o juízo estabelece e põe a realidade, ora, não se pode estabelecer uma realidade, ou um juízo, sem a devida reflexão e estudo. Em inúmeras situações o corpo exposto à massa aquosa, apresenta sinais externos do referido 
afogamento, a saber: pele anserina, resfriamento corpóreo acentuado, dependendo do meio aquoso, pode-se encontrar a ação da fauna, como perdas de segmentos corpóreos, cogumelo de espuma, mancha verde da putrefação na região esternal ou no pescoço, em oposição à presença da mesma na região ilíaca direita dos outros tipos de morte, dentes róseos, maceração da epiderme, etc. Ora, a simples presença dos sinais acima não tipifica a morte por afogamento, significa simplesmente que aquele corpo foi submetido por determinado tempo à ação do meio aquoso, ou meio líquido. Para afirmar-se que determinado corpo encontrado em massa líquida foi vítima de asfixia mecânica por afogamento, é necessária a presença de sinais internos como os citados a seguir: enfisema aquoso, equimoses subpleurais, presença de líquido em vias respiratórias e, em alguns casos, presença de corpos estranhos nas vias respiratórias (devido a afogamentos em meios, como lamaçais, pântanos e a presença de plânctons), as manchas de Tardieu e ou as manchas de Paltauf, presença de líquido no ouvido médio, presença de líquidos no tubo digestivo alto (estomago e duodeno), hemodiluição, e ainda hemorragias na região temporal e etmoidal. Tanto os sinais externos, como os sinais internos, tratados isoladamente, constituem enunciados singulares, que na visão de Popper não produz ciência. No entanto, quando se tratam estes enunciados no seu conjunto, temos a possibilidade, na mesma visão de Popper, de representá-los por enunciados universais, ou seja, fazer-se ciência. Neste último caso, podem-se falsear os enunciados, ou como se diz na linguagem pericial, duvidar-se do que está "muito à vista", pois em diversas situações, o corpo foi jogado na água após a morte, ou morreu de outra causa naquele meio. Em ambas as situações, é óbvio que se o corpo não apresenta os sinais internos do afogamento, não se pode cogitar da hipótese da referida possibilidade de afogamento, devendo o perito buscar outras causas para justificar o diagnóstico.

Nas possibilidades acima referidas, a figura do decisível definida por Popper, se impõe, levando-se em consideração que esta figura, deve ter um caminho unilateral ou unívoco (para ser aceita como justificativa de ciência). Por exemplo, ao se aceitar que os sinais internos é que definem a morte por afogamento e não os sinais externos, a figura do decisível fica definida no sentido unilateral de forma conclusiva.

No enunciado que diz: "o que caracteriza a morte por afogamento são os sinais internos e não unicamente os sinais externos", têm-se a figura do necessário, e a figura do demonstrável, que em Aristóteles, caracteriza a ciência. Desta forma, tanto na visão 
popperiana, quanto na visão aristotélica, pode-se dizer do sentido científico e da sua prática, ao se estabelecer o diagnóstico adequado em situações análogas às acima referidas a cerca do afogamento.

A fundamentação científica do agir pericial, vivenciado, cultuado no âmbito da Medicina Legal, deve permitir que o conceito de conhecer, no sentido aristotélico do termo, seja referencial seguro e por isso mesmo norteie e ao mesmo tempo explique a referida prática. Garcia Morente (1980: 113), quando aborda os temas: teoria do conhecimento, conceito, juízo, raciocínio e Deus em Aristóteles, assim se pronuncia:

Para Aristóteles, conhecer significa duas coisas. Conhecer significa, primeiramente, formar conceitos, quer dizer, chegar a constituir em nossa mente um conjunto de notas características para cada uma das essências que se realizam na substância individual. Os processos de abstração e de generalização que, sobre o material da percepção sensível, realizamos, conduzem-nos a formação de um arsenal de conceitos. Saber é ter muitos conceitos. Quem mais sabe é aquele que tem mais logoi na inteligência, na mente. Quanto mais tiver, mais saberá. Porém, conhecer significa em segundo lugar, isto também: aplicar estes conceitos que formamos a cada coisa individual; colocar cada coisa individual sob o conceito, chegar à natureza, contemplar a substância, olhá-la e voltar logo para dentro de nós mesmos para procurar, no arsenal de conceitos, aquele conceito que se ajusta bem a essa singularíssima substância, e formular juízo: este é cavalo. E acabou o saber, porque o saber não consiste, como hoje para nós, em descobrir a lei da sucessão dos fenômenos no tempo. Não consiste em explicar por causas antecedentes no tempo, não; mas antes consiste em colocar cada substância sob seu conceito correspondente...

Para Granger, toda prática se inicia no contato com o individual, o ato pericial é eminentemente individual, deve-se levar em consideração todas as características peculiares ao caso, identificar-se as substâncias, ainda, estabelecer-se juízos, para poder-se concluir alegando-se isso, ou aquilo, seja $\mathrm{A}$ ou $\mathrm{B}$, ou ainda, outra variável e até, às vezes, uma vicariância.

Para Aristóteles, segundo o texto acima, substância é necessariamente aquilo que existe unido indelevelmente ao que é a sua essência e aos seus acidentes. Estar-se-ia diante de uma das categorias do ser, daí, a relevância deste conceito. De posse do conceito de substância em Aristóteles, pode-se vislumbrar a complexidade de diversos diagnósticos em Medicina Legal e mais ainda, da malha dos conceitos, na mesma ciência. Como já referenciado, na apresentação do problema desta Tese, tanto na extensão, quanto na variedade dos temas abordados pela referida ciência, inúmeras são as substâncias para as quais seríamos 
obrigados a ter conceitos definidos, especialmente, o conceito de sujeito epistêmico, fulcro deste trabalho e que pode ser assim conceituado e, portanto fundamentar as reflexões pertinentes.

O sujeito epistêmico da Medicina Legal seria o sujeito "médico legista", que não é nenhum legista em especial ou particularmente considerado, mas aquele sujeito ideal, universal, que encarna o que há de comum a todos, ou seja, o conhecimento do sistema, da malha necessária dos conceitos dessa ciência, fruto da atividade matematisante regulada e determinada por leis internas do funcionamento cerebral, escapando assim das vontades e tendências individuais, que poderão eventualmente aparecer a partir daí.

Sem conceitos não se tem ciência, assim o definiram Piaget e tantos outros pensadores, mas este, no âmbito de uma Filosofia da Biologia. A extensa herança de mais de quatrocentos anos da presença da Medicina Legal no mundo ocidental, produziu inúmeros conceitos, alguns validados até hoje, outros substituídos ou aperfeiçoados. A linha mestra do diagnóstico do nascer com vida, ou não, definida por Galeno, no primeiro século da era cristã, permanece até hoje, embora modificadas estejam as suas abordagens. Os conceitos de virgindade, de sedução e de estupro, por exemplo, foram mudados, por abordarem, no âmbito da Medicina Legal, questões da Ética e da Moral, que têm sido suscetíveis de mudanças, atendendo aos hábitos e costumes das sociedades inseridas em diferentes espaços e tempos, mas que, no entanto, não mudaram no que concerne às representações biológicas dos mesmos.

As definições de lesão corporal, de aborto, de infanticídio e dos agentes vulnerantes, por exemplo, permanecem, com as modificações advindas das necessidades lingüísticas, porém, tais modificações não mudam o cerne daquelas definições.

Kant, o criador da Epistemologia, ou, reflexão sobre o conhecimento científico, estabeleceu que se pudesse caracterizar o conceito como a unidade mental do múltiplo. Nos conceitos ou definições existentes na Medicina Legal pode-se dizer que se está atendendo ao estabelecido por Kant ao dizer-se o que é conceito?

Como se definem estupro, lesão corporal, aborto, infanticídio em Medicina Legal nos dias correntes?

O Código Penal brasileiro, oriundo do Decreto-Lei no 2848, de 07-12-1940, seguido pelo Decreto-Lei no 3914 de 09-12-1941 (Lei de Introdução ao Código Penal), alterado pelas 
Leis $n^{\circ} 5346$ de 03-11-1967, 6416 de 24-05-1977, 6799 de 23-06-1980, 6895 de 17-12-1980, 6898 de 30-03-1981, 7251 de 19-11-1984, 8635 de 16-03-1993, 8683 de 15-07-1993, 9127 de 16-11-1995, 9268 de 01-04-1996, 9269 de 02-04-1996, 9281 de 04-06-1996, 9318 de 05-121996, 9426 de 24-12-1996, 9459 de 13-05-1997, 9677 de 02-07-1998, 9714 de 25-11-1998, 9777 de 29-12-1998, 9983 de 14-07-2000, 10028 de 19-10-2000, 10224 de 15-05-2001, 10268 de 28-08-2001, 10467 de 11-06-2002, ainda alterado por Leis que reformaram a Legislação Complementar, emendaram a Constituição Federal e por último por Medidas Provisórias, estabelece, ou seja, tipifica o que sejam o estupro, a lesão corporal, o aborto, e o infanticídio. Estes eventos são assim definidos: Estupro, Art. 213 - Constranger mulher à conjunção carnal, mediante violência ou grave ameaça. Lesão Corporal, Art. 129 - Ofender a integridade corporal ou a saúde de outrem. Aborto, Art. 124- Provocar aborto em si mesma, ou, consentir que outrem lho provoque. Aborto provocado por terceiro, Art. 125 - Provocar aborto, sem o consentimento da gestante. Aborto necessário, I - se não há outro meio de salvar a vida da gestante. Aborto no caso de gravidez resultante de estupro, II - se a gravidez resulta de estupro e o aborto é precedido de consentimento da gestante ou, quando incapaz, de seu representante legal. Infanticídio, Art. 123 - Matar, sob a influência do estado puerperal, o próprio filho, durante o parto ou logo após.

Flamínio Fávero (1975/1991: 686/693), após citar a Legislação Penal da época, refere que a violência seja efetiva ou presumida é o elemento que estabelece o conceito de estupro, pois seria este, "a violência na prática do ato sexual normal”, ou seja, a cópula vaginal perpretada de forma violenta e, portanto, não consentida, rejeitada.

Três são os elementos que integram a figura jurídica do crime: A) o dolo específico manifestado pela intenção do agente em realizar a cópula, como para a velha lei observava Viveiros de Castro; B) o emprego da violência ou da fraude para a satisfação desse intento; C) a realização do ato sexual desejado. Faltando este último elemento, está presente apenas a tentativa.

O mesmo autor às paginas (751/756), conceitua o aborto, após prévia análise da doutrina que outros autores haviam estabelecido, citando Tardieu, Garimond, Leoncini, Lazzaretti, Roeco e Carrara. Fávero, também faz crítica ao Código Penal de 1890, pois segundo a sua opinião o referido código só protegeria a mulher e apenas indiretamente dava atenção ao feto. Para que se entenda a visão do autor sobre o aborto, veja-se o texto das páginas citadas abaixo: 
É preciso, inicialmente, distinguir o ato do produto. Ao primeiro, cabe a denominação de abortamento, sendo aborto o produto expelido. Os franceses têm os dois vocábulos - avortement e avorton com essa diversa significação. E nós também os temos, como puríssimo vernáculo, e nas mesmas acepções. Caldas Aulete registra: abortamento "ação de abortar" e aborto "efeito da ação de abortar", animal que nasceu antes de ter adquirido as condições necessárias para a vida exterior. O termo abortamento foi criado há cerca de 100 anos por Antônio José de Lima Leitão, como se lê na tradução da Medicina Legal de Sedillot, de sua autoria. Em seguida, convém atender para os critérios médico-legal e médico. Em relação ao primeiro, chama-se abortamento a interrupção da gravidez antes do tempo normal, com morte do embrião. É indiferente sua expulsão ou não, assim como a viabilidade do produto sobre o qual incidem as manobras criminosas. A obstetrícia só considera abortamento se ocorre expulsão violenta do feto, antes de ser vital, isto é, até o $6^{\circ}$ mês. Depois, a denominação é parto prematuro.

Quando trata do infanticídio, Flamínio Fávero, seguindo seu método de escrever e ensinar, começa fazendo uma reflexão sobre as doutrinas, internacional e pátria, e fundamenta suas reflexões sobre a legislação antiga e a vigente à sua época, só então conceitua, às páginas (765/806):

Força é convir que esse crime é de feição especial. Liga-se, em regra, a uma falta conseqüente à sedução, adultério, estupro, incesto. É, pois, o epílogo de uma gravidez ilícita, com parto quase sempre não assistido, clandestino. Há assim, em relação à mulher, uma desonra a ocultar e uma emoção violenta que age, tudo criando estado especial no espírito de uma infeliz que não soube ou não pode resistir. Mas, há a mesma situação, no que diz com seus parentes próximos perturbados e excitados pelo irremediável de uma dolorosa situação de fato. (...) Para haver o crime de infanticídio, são necessários os seguintes elementos: a) que se trate de feto nascente ou infante recém-nascido; b) que tenha havido vida extra-uterina; c) que a morte seja intencional. (...) Não importa que a vítima seja viável ou não. A monstruosidade pode ser objeto de infanticídio. Exclui-se, apenas, a mola, que é um ovo degenerado, à qual não assiste possibilidade de ter vida fora do ventre materno e, menos ainda, de se desenvolver como ente humano. Vítima do infanticídio pode ser não só o verdadeiro recém-nascido, isto é, o feto já nascido, já fora do álveo materno, malgrado continue preso pelo cordão umbilical, mas também o feto nascendo ou nascente, em plena expulsão embora ainda não tenha respirado. (...) O critério médico-legal independe de qualquer prova de viabilidade e de maturidade exige, tão somente, a verificação e o estudo dos vários elementos que podem falar da recenticidade do nascimento da criança e da vida extra-uterina desta.

Ao se referir às “lesões pessoais”, Fávero (1975/1991: 220), critica o Código Penal de 1890 e estende sua observação ao código de 1940, que divide as lesões pessoais em lesões corporais, à saúde e à mente. Assim comenta o referido autor:

Nas lesões pessoais, elemento objetivo de um crime, pode ser atingida a integridade física ou psíquica da vítima. Em rigor, talvez coubesse melhor, a 
tais lesões, o qualificativo de pessoais do que corporais. De fato, a pessoa se integra pela reunião da parte corporal, propriamente dita, à parte psíquica. Não são raros os casos de lesões na personalidade de alguém, em sua parte psíquica ou física mesmo, por traumatismo à distância, puramente moral: um susto, uma notícia desagradável, etc., e isto, havendo ou não prévia lesão orgânica, tudo ligado às condições de resistência, de suscetibilidade do paciente. Ficarão fora da lei tais danos? É claro que não, à luz do preceito contido no artigo 11 do Código. Assim, a crítica que se fazia ao Código de 1890 deve subsistir, parece-me, para o de 1940, quanto à restrição do título do capítulo em que se incluem tais lesões.

Considerando-se a relevância do conceito na ambiência científica, confirmando-se o referido por vários autores, ao dizerem que sem conceito não se faz ciência, escolheu-se para estas reflexões temas tratados pela Medicina Legal, desde os seus primórdios, quais sejam o estupro, o aborto e o infanticídio, pela inconteste importância social, psicológica, moral e técnica, e ainda, as lesões corporais pelas questões técnicas envolvidas no seu diagnóstico, como também, pelo aspecto do "freqüente" como uma das condições para se fazer ciência na visão aristotélica do termo. A escolha da obra das figuras de Fláminio Fávero e Genival Veloso de França, como referencial na abordagem doutrinaria dos temas acima referidos, deve-se às efetivas contribuições que aquele em seu tempo realizou e este realiza nos dias correntes. Assim, França (2008: 228) define o estupro:

É, portanto, o estupro a posse sexual da mulher por meios violentos efetivos ou presumidos, ou pela grave ameaça, uma forma de constrangimento ilegal que transcende o mundo dos crimes contra os costumes. O bem jurídico protegido é a liberdade sexual da mulher: um direito de dispor sobre seu corpo, estabelecendo um critério de eleição às suas relações. Constranger significa violentar, coagir, impedir os movimentos, compelir, obrigar por força. É uma maneira de obrigar alguém a fazer o que não quer. No estudo em questão, possuir sexualmente mulher pela violência ou coação.

Quando trata do aborto, França (2008: 275/ 284) faz périplo sobre os diversos enfoques históricos do tema, aborda as diferentes legislações antigas e modernas e classifica o aborto em: terapêutico, sentimental, eugênico, social, por motivo de honra conceituando-o da seguinte maneira:

A clássica definição de aborto é a de Tardieu, como sendo 'a expulsão prematura e violentamente provocada do produto da concepção, independentemente de todas as circunstâncias de idade, viabilidade e mesmo de formação regular'. Todavia, essa definição é falha porque situa apenas os casos de 'expulsão do produto da concepção', pois, sendo a mola hidatiforme considerada como tal, embora degenerado, não se pode considerar como aborto. Ainda mais quando se verifica que nem sempre há a expulsão do ovo. Outra definição é a de Carrara, modificada por Nelson 
Caparelli, que não deixa de atender os imperativos da lei: 'Aborto criminoso é a morte dolosa do ovo no álveo materno, com ou sem expulsão, ou a sua expulsão violenta seguida de morte'. A mais simplista é a de Nilton Sales: 'A morte dolosa do ovo'. Morisani conceitua como 'a interrupção da gravidez, seguida ou não da expulsão do feto, antes da época da sua maturidade'. E Garimaud coloca o aborto criminoso como 'a cessação prematura e dolorosa da gravidez, ou sua interrupção intencionalmente provocada, com ou sem aparecimento dos fenômenos expulsivos'. O certo é que nenhuma dessas definições está isenta de crítica. Discute-se qual o termo mais correto: 'aborto' ou 'abortamento'. O primeiro seria o produto expelido e o segundo traduziria o ato. Nos documentos médico-legais, deve-se usar sempre o termo 'aborto'. Para alguns estudiosos da língua, é termo mais correto; é terminologia mais corrente; é assim que se expressa à lei substantiva penal. Sabemos, que em Medicina Legal, não há aborto sem abortamento, pois o aborto espontâneo pertence ao estudo e à aplicação da Obstetrícia. Por outro lado, pode haver a tentativa de abortamento sem aborto. Dessa forma, nossa codificação penal ao incriminar o aborto não distingue entre ovo, embrião ou feto. Sempre que ocorrer intencionalmente a morte do concepto ou sua expulsão violenta seguida de morte está configurado o crime de aborto.

Quando trata do infanticídio, França (2008: 294/296), faz ampla avaliação do termo e da sua relevância na legislação, quanto na prática pericial, ao denominá-la de crucis peritorum; releva também a exposição de motivos do Código Penal de 1940, ainda vigente, com as leis que o modificaram e referidas acima e que o denomina de delictum exceptum; discute ainda o termo "estado puerperal", que atenuaria a pena e talvez, reduziria a ação criminosa. $\mathrm{O}$ referido autor assim trata o referido tema:

O Código Penal de 1940 qualificou infanticídio como 'matar, sob a influência do estado puerperal, o próprio filho, durante o parto ou logo após'. Esse tipo de delito chegou a ser punido como homicídio agravado sujeito a pena de morte através de execuções graves. Na Idade Média, as mães que matavam seus próprios filhos de forma secreta, voluntária e perversa eram enterradas vivas ou empaladas segundo o costume. (...) A legislação vigente adotou como atenuante no crime de infanticídio a condição biopsicossocial do estado puerperal, justificado pelo trauma psicológico, pela pressão social e pelas condições do processo fisiológico do parto desassistido - angústia, aflição, dores, sangramento extenuação, cujo resultado traria o estado confusional capaz de levar ao gesto criminoso. (...) O estado puerperal, expressão ambígua e situação contestada pelos médicos, tem merecido, através de todo esse tempo, severas críticas, sendo, inclusive, considerado por alguns como uma simples ficção jurídica no sentido de justificar a benignidade de tratamento penal, quando a causa principal seria a pressão social exercida sobre a mulher cuja gravidez fere a sua honra. Na verdade, não há nenhum elemento psicofísico capaz de fornecer à perícia elementos consistentes e seguros para se afirmar que uma mulher matou seu próprio filho durante ou logo após o parto, motivada por uma alteração chamada 'estado puerperal', tão-somente porque tal distúrbio não existe como patologia própria nos tratados médicos. (...) Nada mais fantasioso que o 
chamado estado puerperal, pois nem sequer tem um limite de duração definido.

Levando-se em consideração o "freqüente", tratado por Aristóteles nos "Segundos Análiticos" e referenciado nesta Tese, como condição para no "mundo sublunar" aristotélico, poder-se tender ao universal e ao necessário, e se fazer ciência; o tema lesões corporais em Medicina Legal tem, decisivamente, o caráter do "freqüente" como referido acima. Veja-se como França (2008: 156/157) trabalha o referido tema:

As lesões corporais, quando estudadas no tocante à avaliação quantitativa e qualitativa do dano, de natureza penal, têm o significado médico-jurídico de caracterizar, no dolo ou na culpa, um ato ilícito contra a integridade física ou a saúde da pessoa, como proteção da ordem pública e social. Melhor seria a designação "lesões pessoais" em lugar de lesões corporais, uma vez que se tem a idéia de que apenas estariam contemplados os danos do corpo. $\mathrm{O}$ legislador, no entanto, redime-se no enunciado do artigo 129 quando anuncia: 'Ofender a integridade corporal ou a saúde de outrem'. E a saúde, obviamente, é física e psíquica.

Pode-se observar, que desde Aristóteles, passando pela Filosofia da Ciência, com Kant, Granger e Piaget, como referido nas páginas acima, o estabelecimento de conceitos, seu uso adequado, as relações advindas dos seus usos, como fundamentais para que se tenha ciência. Aristóteles, impelido pela necessidade de definir o "ser", e, por consequiência chegar à estrutura do mesmo, o fez definindo as suas Categorias, possibilitando então que se conceitue aquilo que desde aquela época, instiga os pensadores da Filosofia. Como enfatiza Garcia Morente (1980: 106,107), Aristóteles, dividiu a estrutura do ser, em três aspectos: do ser em geral, da substância e da realização, nas páginas referidas o autor escreveu que:

A primeira maneira de atribuir ao sujeito um predicado chama-a Aristóteles "substância". Já conhecemos este termo. A substância é a primeira categoria que ele enumera na sua lista: é o ponto de vista no qual nos situamos para dizer que algo "é": este é o homem, este é o cavalo, este é peixe. Quando dizemos de algo que é isto ou aquilo, aquilo que é, então consideramos este algo como uma substância e o que dele dizemos isto é ele. Mas não nos colocamos somente neste ponto de vista. Vem um segundo ponto de vista. De algo que é real podemos também predicar o muito e o pouco. Podemos dizer de um homem que é grande ou pequeno; podemos dizer de um cavalo que é grande ou pequeno; de uma coleção de coisas que são muitas ou poucas. De sorte que temos, aqui outro ponto de vista do qual focalizamos o ser e que Aristóteles chama a "quantidade". Mas qualquer ser pode ser ainda focalizado de um terceiro ponto de vista. Depois de ter dito o que é e quanto é, ainda podemos dizer que é vermelho, verde, nobre, ignóbil, feio, bonito. Este é o ponto de vista que Aristóteles chama a "qualidade". Logo, consideramos os seres uns em relação aos outros. De um ser podemos predicar, igualmente, que é maior do que outro, menor do que o outro, igual 
a outro. A este tipo de predicação chama Aristóteles "relação". Podemos, ainda, ante um ser, tentar determinar onde está, e dizer: está aqui ou lá, em Atenas. A este ponto de vista sobre qualquer ser chama Aristóteles "lugar". Do mesmo modo, temos o ponto de vista do "tempo". De um ser podemos predicar quando é, quando deixa de ser, quando foi. Podemos dizer que é agora e continua a ser ou que deixou de ser. Outro ponto de vista é determinar em um ser aquilo que esse ser faz. Dizemos que um machado é cortante; dizemos que uma semente germina. A este ponto de vista chama Aristóteles "ação". E, por último, de qualquer ser podemos também predicar, não o que ele é, mas o que ele padece, o que ele sofre, a árvore é cortada; o homem é morto. A esse ponto de vista chama Aristóteles "paixão".

Garcia Morente (1980: 107), ainda faz referência a duas outras categorias, que Aristóteles usa algumas vezes e em outras não as usa, tais como: "posição" e "estado", que no entendimento do autor deveria ter produzido dificuldades metafísicas e lógicas para o Estagirita, o que justificaria o uso e a supressão das mesmas. Segundo o mesmo autor, para o Filósofo, as Categorias, tanto formam a estrutura do "ser", quanto organizam o "pensar", tendo então, sentido "ao mesmo tempo lógico e ontológico".

Tendo-se como fundo de quadro as categorias do ser acima referenciadas e estabelecidas por Aristóteles também como base para o pensar - a seguinte possibilidade fenomênica demonstra, em Medicina Legal, como o agir pericial deve ser vivenciado: o encontro de cadáver em área pública é freqüente em certas áreas das urbes nacionais, e quando se usa a palavra cadáver, já se estabelece a categoria de substância, do pensar aristotélico. Se, ao examinar-se o referido cadáver, percebe-se a presença de lesões corporais definidas, como feridas pérfuro-contusas presentes no segmento torácico do mesmo, estabelece-se a categoria de quantidade; ao se definir o grupo racial do referido cadáver, se estabelece a categoria de qualidade, ao se comparar as lesões presentes, estabelece-se a categoria de relação; ao se descrever o local de encontro do cadáver, estabelece-se a categoria de lugar; ao se observar os tipos de lesões, estabelece-se a categoria de ação; ao se detalhar a presença dos ferimentos, percebe-se a categoria de paixão; ao se verificar o cadáver deitado em decúbito dorsal, estabelece-se a categoria de posição; ao se observar a presença de mancha verde abdominal na fossa ilíaca direita, estabelece-se a categoria de estado, pois estaria iniciado o "estado" de putrefação naquele cadáver.

No âmbito da Medicina Legal, ciência biológica amparada nas ciências físicas e contextualizada na vivência social, logo ciência que tem origem na empiria, o uso do pensar os fenômenos deve ir além das denominadas categorias do ser, quando se pretende orientar e 
definir o agir pericial. Haverá a necessidade de conhecimentos organizados em conceitos, que originados na experiência, estruturem um conjunto teorético e que, tendo como base juízos extensivos, portanto sintéticos, no sentido kantiano do termo, (como veremos mais abaixo) orientem o referido agir pericial, este, fulcro existencial da própria Medicina Legal.

\section{C) Das condições a priori do visum et repertum}

Conceito, para Kant, como já citado acima, é a unidade mental do múltiplo, e sendo unidade do múltiplo, contempla a pluralidade e o elemento que a congrega, que a organiza, isto é, os juízos, que Kant, classifica em: analíticos e sintéticos, e ainda em analíticos e sintéticos a priori. O juízo em Kant, já foi dito, estabelece e põe a realidade. Para Garcia Morente, a filosofia kantiana é antes de tudo, uma teoria do conhecimento. Seria então, porque essa teoria do conhecimento diz respeito ao conhecimento científico uma epistemologia e organizaria assim a possibilidade da ciência, tendo como elemento essencial a ratio e o logos. O conhecimento, na ótica de Kant inicia-se na experiência como foi referido acima, mas dela não deriva. Kant (1994: 36- 37), assim diferencia o conhecimento puro e o conhecimento empírico:

Não resta dúvida de que todo o nosso conhecimento começa pela experiência; efetivamente, que outra coisa poderia despertar e pôr em ação a nossa capacidade de conhecer senão os objetos que afetam os sentidos e que, por um lado, originam por si mesmos as representações e, por outro lado, põem em movimento a nossa faculdade intelectual e levam-na a comparálas, ligá-las ou separá-las, transformando assim a matéria bruta das impressões sensíveis num conhecimento que se denomina experiência? Assim, na ordem do tempo, nenhum conhecimento precede em nós a experiência e é com esta que todo conhecimento tem o seu início. Se, porém, todo o conhecimento se inicia com a experiência, isso não prova que todo ele derive da experiência. Pois bem poderia o nosso próprio conhecimento por experiência ser um composto do que recebemos através das impressões sensíveis e daquilo que a nossa própria capacidade de conhecer (apenas posta em ação por impressões sensíveis) produz por si mesma, acréscimo esse que não distinguimos dessa matéria-prima, enquanto a nossa atenção não despertar por um longo exercício que nos torne aptos a separá-los. Há, pois, pelo menos, uma questão que carece de um estudo mais atento e que não se resolve à primeira vista; vem a ser esta: se haverá um conhecimento assim, independente da experiência e de todas as impressões dos sentidos. Denomina-se a priori esse conhecimento e distingue-se do empírico, cuja origem é a posteriori, ou seja, na experiência.

Definida a diferença entre estes tipos básicos do conhecimento na ótica kantiana, o referido filósofo também apresenta um método, um critério ou critérios que possibilitem a referida diferenciação. Se uma proposição se apresenta como necessária unicamente, estar-se- 
ia diante de um juízo a priori, será confirmada esta condição, se a mesma proposição for também universal. A partir do estabelecimento da realidade pelo juízo, Kant apresenta os conceitos de juízo analítico e sintético, que determinam e põem as realidades, inclusive no âmbito da ciência.

A ciência biológica contemporânea tem interpretado o a priori kantiano em várias áreas. Assim Del Nero (2002: 482), ao discutir a emoção e seus distúrbios, escreve:

(...) os significados introjetados (pelo indivíduo) se utilizarão do a priori cerebral para impor-lhe significados dinâmicos treinados durante a história da comunicação da espécie (filogênese) e do indivíduo submerso num contexto comunicacional (ontogênese). Sabemos que há algumas disposições prévias sintéticas no cérebro humano como algumas ordens claras de fuga ou de reação diante de estímulos. Prefiro a visão de um kantismo biológico, fortemente identificado com uma certa corrente da etologia. Cf. a respeito de sintéticos cerebrais a priori e da possibilidade de um a priori biológico ao gosto kantiano: 1)Young, J. (1987), Philosophy and the Brain. Oxford University Press. 2) Young, J. (1978) Programs of the Brain. Oxford University Press; Cf. a respeito de etologia e particularmente a obra de Konrad lorenz: Lorenz K. , Popper, K (1990) L' avenir est ouvert. Paris, Flammarion.

Para citar biólogos brasileiros, Erasmo G. Mendes, Professor Titular da disciplina Fisologia Animal II do Instituto de Biociências da USP, em Fisiologia: crises - escreve:

(...) Modernamente, essa visão vem sendo posta em cheque e ganha terreno a admissão de que a mente, como queria Kant com seus conceitos, tornar-se-ia não apenas plausível, mas inteiramente de acordo com a corrente principal do pensamento evolucionista.

Agnaldo Garcia, biólogo, Professor da UFES, com certeza o maior conhecedor da obra de Konrad Lorenz no Brasil, assim se pronuncia em seu artigo Cognição e evolução: a contribuição de Konrad Lorenz (2005: 91 e 92):

(...) Neste artigo o autor (Lorenz) examina a doutrina de Kant do a priori à luz da Biologia contemporânea. A mesma influência kantiana está presente em sua discussão das formas inatas da experiência possível (Lorenz, 1943a).

(...) As formas da experiência possível, independentes de experiência anterior, as formas do pensamento e intuição que Kant denominou esquematizações a priori são construídas em nosso aparato perceptivo na filogênese. Só podemos experimentar, perceber ou pensar algo, com base em hipóteses inatas, a priori.

Assim, a Biologia contemporânea retomou a idéia do a priori de Kant para ressaltar a importância das condições orgânicas que precedem e são condição do experimentar, do perceber ou do pensar. Contudo, apenas Piaget (na primeira metade do Século XX já mostrava a importância do conceito de $a$ priori na obra do filósofo de Köenigsberg), 
preocupou-se em tomar a teoria kantiana para explicar como são construídos os juízos, as sentenças, pela inteligência, pela Razão, quando esta se aplica à realidade, à experiência, no sentido de explicá-los, desvendá-los e descrevê-los.

Daí a utilidade das considerações de Kant para a Medicina Legal, em particular, onde se está sempre lidando com aquilo que vem da experiência e com o que é imposto pela capacidade de raciocinar do perito, que, naturalmente, vem antes da experiência atual.

Veremos como nenhum dos dois tipos de juízo considerados anteriormente (juízos analíticos e sintéticos) é satisfatório e que seremos obrigados a admitir, com Piaget, no âmbito da ciência biológica, o juízo sintético a priori, de há muito descartado da ciência física, por influência metafísica do Positivismo Lógico que jamais levou em conta o funcionamento cerebral que seria o aspecto a priori no âmbito da ciência biológica. A posição piagetiana será retomada e explicada mais adiante. Antes disso, precisaremos melhor entender as colocações de Immanuel Kant, pois de outra forma aquelas de Piaget cairiam no vazio e não seriam adequadamente avaliadas, valoradas e conseqüentemente valorizadas. Para Kant, (1994: 4243):

(...) em todos os juízos, nos quais se pensa a relação entre um sujeito e um predicado (apenas considero os juízos afirmativos, porque é fácil depois a aplicação aos negativos), esta relação é possível de dois modos. Ou o predicado B pertence ao sujeito A como algo que está contido implicitamente nesse conceito $A$, ou $B$ está completamente fora do conceito A, embora em ligação com ele. No primeiro caso chamo analítico ao juízo, no segundo, sintético.

Kant, ao estabelecer na Crítica da Razão Pura, que a Filosofia carece de uma ciência que determine as possibilidades, os princípios e a extensão de todo conhecimento a priori, definiu que "os juízos da experiência, como tais, são todos sintéticos", e, que todas as ciências teóricas da razão encontram como princípios, juízos sintéticos a priori. Como se definem e se tornam possíveis para o filósofo os conceitos de juízos analíticos e sintéticos a priori? (Que seriam justamente aqueles compatíveis com uma ciência biológica).

Garcia Morente (1980: 224-225), ao comentar os fundamentos da filosofia kantiana, assim explicitou estes juízos, ainda em relação à ciência física, como pretendeu Kant:

Então é absolutamente indispensável que essa ciência de Newton, que não é [constituída pelo] juízo analítico nem o é pelo juízo sintético, tenha um tipo de juízo que lhe seja próprio. Isto significa que devem existir como esqueleto ou estrutura da ciência físico-matemática, uns juízos que não sejam nem os juízos sintéticos nem os juízos analíticos; ou melhor, dito, tem que haver na 
ciência uns juízos que tenham dos juízos analíticos a virtude de ser a priori, isto é, universais e necessários, independentes da pequena ou grande experiência. $\mathrm{O}$ que pretende Kant não é nenhuma coisa extraordinária. É aquilo em que crêem todos os físicos do mundo. Todos os físicos do mundo crêem que uma experiência bem feita basta para fundamentar uma lei. E, todavia, essa lei vale além dessa experiência concreta, vale para todas as experiências possíveis passadas, presentes e futuras. Por conseguinte, os juízos da ciência são universais e necessários, da mesma maneira que os juízos analíticos são a priori. Porém, não são analíticos, porque se fossem analíticos, não aumentaria em nada nosso conhecimento. Teriam que ser, pois, sintéticos; isto é, objetivos; ou seja, que aumentassem realmente nosso conhecimento sobre as coisas. Mas então teriam que estar fundados na experiência e seriam particulares e contingentes. Tiremos-lhes este fundamento da experiência e digamos que os juízos da ciência têm que ser necessariamente sintéticos e a priori ao mesmo tempo. O problema consistirá então em mostrar como é possível que existam juízos sintéticos $a$ priori; que condições têm que ocorrer para que sejam possíveis os juízos sintéticos a priori. O que faz Kant é mostrar que, efetivamente, as ciências estão constituídas por juízos sintéticos a priori; e o mostra pela demonstração, ensinando-os, exibindo-os.

Segundo Garcia Morente, a resposta às possibilidades do juízo sintético a priori, é o que fundamenta a obra de Kant. No universo da Medicina Legal, onde o agir pericial ocorre no particular, no singular, fundamentado nos saberes técnicos, mais que nos saberes científicos, de onde se deve, após ato pericial específico, elaborar-se documento, (ou seja, proposições/enunciados) apresenta-se então, situação peculiar. Da interação sujeito/objeto, presente no exame pericial, que deve estabelecer premissas concretas, consistentes e verdadeiras (derivadas do veritas, ou seja, relato verdadeiro de evento passado), que formule, também, silogismo apodítico e não aporia só se podem estabelecer "juízos extensivos" no sentido kantiano do termo, fruto, portanto, da experiência, ou seja, sintético. Nesta situação peculiar, não se está gerando conhecimento da forma como Kant o entende, mas sim, tautologia, pois o perito no sentido unilateral do "decisível" segundo a visão popperiana do termo já assinalada, ao relacionar as premissas referidas acima e concluí-las segundo os princípios da Lógica Clássica, ou seja, formando um silogismo, não está gerando conhecimento, está sim, simplesmente, relatando evento ou eventos, ou seja, algo como A=A. Tautologia "necessária", pois o documento médico-legal deve estabelecer idealmente a verdade, tanto no sentido da Aletheia, quanto no sentido de Veritas, não pode gerar o pseudos nem o mentior, quando não possível a verdade, pelo menos a verossimilhança, (embora o conceito de verossimilhança não seja referência nem para o Direito, nem para a Medicina Legal, quando se trata de predicar sobre conceito). Tal documento serve, no entanto, à 
fundamentação dos preceitos da Justiça, no que tange à denominada "prova científica", prova esta já definida acima.

Quando o tema é a ciência, como conjunto de enunciados, proposições, que fundamentam um sistema teorético, no caso em tela, o da Medicina Legal, com todo um universo pesquisado e a pesquisar, que terá, portanto, um caráter heurístico, os Juízos a serem estabelecidos só poderiam ser, necessariamente, sintéticos e a priori, pois deveriam aumentar o nosso conhecimento e terem o caráter de necessidade como preconizaram, por exemplo, Mittermaier, Malatesta, Gorphe e tantos outros visando o estabelecimento da Justiça, sempre, para nós, no sentido de John Rawls, acima citado.

Kant (1994: 46/49) explica o conceito e coloca as premissas para a construção do "juízo sintético a priori". Tal moto explicativo sugere uma busca da arethé aristotélica, ou seja, uma vivência da excelência no pensar a filosofia, mais ainda, no pensar uma epistemologia, pois como tão bem explica Garcia Morente (citado acima), a filosofia kantiana é uma real teoria do conhecimento, naturalmente, o científico. Kant à página 46 da obra citada diz: “em todas as ciências teóricas da Razão encontram-se, como princípios, juízos sintéticos a priori”. O que seria este juízo? O filósofo nas páginas referidas acima profere:

Os juízos matemáticos são todos sintéticos. Esta proposição parece até hoje ter escapado às observações dos analistas da razão humana e mesmo opor-se a todas as suas conjecturas; é, contudo, incontestavelmente certa e de conseqüências muito importantes. Como se reconheceu que os raciocínios dos matemáticos se processam todos segundo o princípio da contradição (o que é pela natureza de qualquer certeza apodítica), julgou-se que os seus princípios eram conhecidos também graças ao princípio da contradição; nisso se enganaram os analistas, porque uma proposição sintética pode, sem dúvida, ser considerada segundo o princípio da contradição, mas só enquanto se pressuponha outra proposição sintética de onde possa ser deduzida, nunca em si própria. Antes de mais, cumpre observar que as verdadeiras proposições matemáticas são sempre juízos a priori e não empíricos, porque comportam a necessidade, que não se pode extrair da experiência. [grifo nosso] Se não se quiser admitir isso, pois bem, limitarei a minha tese à matemática pura, cujo conceito já de si exige que não contenha conhecimento empírico, mas um conhecimento puro e a priori.

(...) A ciência da natureza (física) contém em si, como princípios, juízos sintéticos a priori. Limitar-me-ei a tomar, como exemplo, as duas proposições seguintes: em todas as modificações do mundo corpóreo a quantidade da matéria permanece constante; ou, em toda a transmissão de movimento, a ação a reação têm de ser sempre iguais uma à outra. Em ambas as proposições é patente não só a necessidade, portanto a sua origem a priori, mas também que são proposições sintéticas. Pois no conceito de 
matéria não penso a permanência, penso apenas a sua presença no espaço que preenche. Ultrapasso, assim, o conceito de matéria para lhe acrescentar algo à priori que não pensei nele. A proposição não é, portanto, analítica, mas sintética e, não obstante, pensada a priori; o mesmo se verifica nas restantes proposições da parte pura da física. $\mathrm{Na}$ metafísica, mesmo considerada apenas como uma ciência até agora simplesmente em esboço, mas que a natureza da razão humana torna indispensável deve haver juízos sintéticos a priori; por isso, de modo algum se trata nessa ciência de simplesmente decompor os conceitos, que formamos a priori acerca das coisas, para os explicar analiticamente; o que pretendemos, pelo contrário, é alargar o nosso conhecimento a priori, para o que temos de nos servir de princípios capazes de acrescentar ao conceito dado alguma coisa que nele não estava contida e, mediante juízos sintéticos a priori, chegar tão longe que nem a própria experiência nos possa acompanhar. Isso ocorre, por exemplo, na proposição: o mundo tem de ter um primeiro começo, etc. Assim, a metafísica, pelo menos em relação aos seus fins, consiste em puras proposições sintéticas a priori.

Parafraseando Kant (1994: 50), quando pergunta: “como é possível a Matemática? Como é possível a Física?", poder-se-ia, ousadamente, perguntar: seria realmente possível a existência do juízo sintético a priori na Medicina Legal, o que faria dela também uma ciência da Razão, apesar de pertencer ao universo das ciências biológicas? Ou o amplo leque de interesses desta ciência invalida essa possibilidade? Existiriam na mesma ciência, enunciados, proposições que seriam juízo sintético puro ou a priori? Para responder a essas questões, busquemos enunciados que contenham juízos neste sentido definidos por Kant.

Além disso, vamos supor que as extensões dos interesses e da temática contidas na Medicina Legal garantam a possibilidade de se encontrar tais juízos.

O enunciado: "Toda ação instrumental vulnerante é definida no âmbito da prática pericial pelas lesões e conseqüentes representações das mesmas no corpo humano", além de constituir-se em fato concreto, para o executor destas práticas, pode ser representado por equação da Lógica matemática e é necessariamente deduzido de outras ações instrumentais, que não estariam nem no âmbito do perito, nem do corpo humano atingido, portanto, tratar-seia aqui de um juízo sintético no sentido kantiano do termo, porque coloca a realidade, porque é oriundo da experiência, mas é a priori, porque é deduzido de situação diversa da referida acima. Ora, tal capacidade do ser humano de deduzir, não deriva da experiência, assim o assevera Kant, mas sim, como bem mostrará Jean Piaget, de possibilidade orgânica que o ser humano traz consigo ao nascer. 
A mais sofisticada ponte entre a ótica idealista transcendental (que se fundamentou nos elementos da física newtoniana para falar da experiência e na crítica da própria Razão para criar uma teoria do conhecimento), ou seja, entre o logos kantiano e o complexo, multiforme, multifatorial universo da Biologia moderna, está nos textos de Piaget inspirados na teoria de Kant por ele inserida no mundo da Biologia. Em seu livro Les liaisons analytiques et synthétiques (1957) inicia o Prólogo dizendo:

Tandis que Kant distinguait les deux dichotomies de l'a priori - aposteriori et de l'analytique -synthétique selon les diverses combinaisons que l'on sait, l'empirisme logique contemporain prétend caractériser la dualité des connaissances lógico-mathématiques et des connaissances physiques (ou expérimentales en general) au moyen de la seule dichotomie de l'analytique et du synthétique, l'analytique se confondant alors avec le déductif pur et le synthétique se définissant par le recours à la constatation.

Tradução livre: Enquanto Kant distinguia as duas dicotomias do apriori/aposteriori e do analítico/sintético, segundo as diversas combinações que conhecemos, o empirismo lógico contemporâneo pretende caracterizar a dualidade dos conhecimentos lógico-matemáticos e dos conhecimentos físicos (ou experimentais em geral) por intermédio de uma única dicotomia, analítico e sintético; o analítico confundindo-se com dedutivo puro, lógicomatemático, e o sintético definindo-se pelo recurso à constatação. [ grifo nosso]

Continua Piaget, ainda no Prólogo:

L'intelligence se laisse-t-elle départager em deux aspects entiérement dissociables: l'un constitué par des formes ou des structures logiques qui tiendraient au langage, l'autre par des contenus qui tiendraient à l'expérience perceptive? Ou, au contraire, une conception opératoire de l'intelligence, fondée sur les actions que le sujet exerce sur les objets, aboutit-elle nécessairement à considérer les formes et les contenus comme le produit d'une différenciation progressive entre les coordinations des actions et leurs résultats (différenciation de plus em plus poussée, mais peut-être jamais achevée sur le terrain de la pensée "naturelle", en opposition avec les théories axiomatisées)? Telle est em définitive la question psychologique que recouvre le débat logique sur la continuité ou la discontinuité de l'analytique et du synthétique.

Tradução livre: Mas, deixar-se-ia a inteligência dividir-se em dois aspectos inteiramente assim dissociáveis: um constituído por formas ou estruturas lógicas que tenderiam à linguagem e o outro por conteúdos que tenderiam à experiência perceptiva? Ou ao contrário, uma concepção da inteligência que considera de um lado o funcionamento das estruturas mentais em construção epigénetica e de outro das ações que o sujeito exerce sobre os objetos, termina necessariamente por considerar forma e conteúdo como produto de uma diferenciação progressiva entre as coordenações das ações e seus resultados; diferenciação esta cada vez maior, mas talvez jamais terminada, no terreno do pensamento natural, em oposição às teorias axiomatizadas? Tal é a questão psicológica que encerra o debate lógico sobre a continuidade ou descontinuidade entre o analítico e o sintético. 
Às páginas 14 e 15 do mesmo livro diz Piaget:

Du point de vue génétique, il est possible de suivre pas à pas chez l'enfant la série des conduites qui aboutissent à la découverte et à la l'utilisation des lois lógico-mathématiques (Telles que la transitivité ou encore la commutativité de l'addition de deux nombres), ainsi que la série des conduites aboutissent à la découverte d'une relation physique (par exemple que le poids d'un objet est indépendant de son volume). On peut alors faire l'hypothèse de la dualité de ces deux séries, et cela à tous les niveaux, mais en reconnaissant qu'elles sont d'autant moins différenciées l'une de l'autre que l'on remonte aux stades les plus primitifs, et que leur différenciation augmente avec le développement. On peut aussi faire l'hypothèse d'une filiation de la série logico-mathématique à partir de la série physique, en admettant alors un processus d'abstraction et de généralisation pour rendre compte du passage de l'une à l'autre, mais la question est en ce cas d'expliquer l'apparition de ce processus si (comme les faits semblent le montrer) le langage et l'éducation n'en sont pas seuls responsables.

Tradução livre: Do ponto de vista genético, é possível seguir passo a passo a série de condutas que fazem com que o ser humano chegue à descoberta e à utilização de leis lógico-matemáticas (como a transitividade ou ainda a comutatividade da adição de dois números), da mesma forma que podemos assistir à seqüencia das condutas que levam à descoberta de uma relação física (por exemplo, que o peso de um objeto é independente de seu volume). Pode-se então levantar a hipótese da dualidade dessas duas séries, e isso em todos os níveis, mas reconhecendo que elas são menos diferenciadas uma da outra quanto mais consideramos os níveis mais primitivos e que, reciprocamente, sua diferenciação aumenta com o desenvolvimento (da embriologia menta)l. Pode-se também levantar a hipótese de uma filiação da série lógico-matemática a partir da série física, admitindo um processo de abstração e de generalização para dar conta da passagem de uma à outra, mas a questão, nesse caso seria a de explicar a aparição desse processo se como os fatos parecem (para nós) demonstrar, a linguagem e a educação não são as únicas responsáveis.

Ora, no processo embriológico da construção das estruturas mentais, específicas para o ato de conhecer, Piaget explica que nos encontramos em presença de dois tipos de experiência: uma experiência lógico-matemática, no sentido de que essa diz respeito às relações que o sujeito estabelece entre os objetos do meio (maior que, menor que, igual, diferente, etc.) e que, portanto, depende da constatação, (feita de juízos sintéticos), mas que no final do processo delas se desliga para se tornar apenas dedutiva, constituída, portanto, de juízos analíticos. A outra é a experiência física que todos nós conhecemos, ou seja, aquela que diz respeito às manipulações dos objetos pelo sujeito do conhecimento. O fundamental é que o biólogo acredita que a embriologia mental pode alcançar o necessário, ou seja, àquilo que não pode deixar de ser como é. Os conceitos formariam aqui, um sistema necessário que poderia ser aplicado a qualquer sujeito enquanto indivíduo. Desde que suas construções 
endógenas chegassem nesse nível de possibilidade inferencial e o indivíduo pudesse então, a partir de premissas verdadeiras chegar à conclusão que se imporia como necessária.

(...) Dans les deux interprétations, le problème est alors de dissocier l'inférence et la constation, et ce probleme est d'une difficulté psychologique considerable parce qu'il existe une multitude de degrés dans l'inférentiel et parce qu'il est fort difficile (sinon impossible) d'atteindre um état qui serait caractérisé par la constatation pure. Tradução livre: Nas duas interpretações, o problema é então de dissociar a inferência e a constatação, e o problema é de uma dificuldade considerável porque existe uma multidão de degraus no inferencial e porque é muito difícil (senão impossível) identificar um estado que fosse caracterizado pela constatação pura.

É do conhecimento da neurofisiologia e mais especificamente da Neurociência, que a interação do animal com o ambiente, ou seja, sua "experiência" com o entorno, especialmente nos denominados "períodos críticos", molda os circuitos neurais e determina desta maneira o comportamento subseqüente. Por outro lado, a experiência também ativa os comportamentos inatos, especialmente no início da vida, ou seja, nos períodos críticos, ou ainda nos períodos de impressão parental. Estes períodos são importantes especialmente ao influenciarem, por exemplo, tanto a aquisição da linguagem quanto por estabelecerem vínculos afetivos, veja-se o estabelecido por Konrad Lorenz (1973) em sua Etologia. A moderna neurofisiologia, através de estudos e pesquisas específicas, demonstra que a experiência determina distintos padrões neuronais que estabelecem funções e conexões neuronais relevantes, como a visão normal, amplamente estudada e cujos estudos mostram a relevância da experiência no estabelecer-se o denominado padrão visual normal.

$\mathrm{Na}$ eventualidade de serem os padrões normais da atividade neuronal perturbados durante o período de impressão parental ou nos períodos críticos, do início da vida, as conexões neuronais são alteradas. Em contrapartida, a evolução normal da atividade neuronal, ou seja, a experiência vivida sem eventos lesivos leva necessariamente ao amadurecimento cerebral e o capacita ao efetivo desempenho extremamente complexo de suas funções.

Piaget (1957: 16), ao tratar da embriogênese mental com seu funcionamento diz:

On voit donc que par le fait même de poser le problème de l'analytique et du synthétique sur le terrain génétique, les termes de ce problème en sont assez profondément modifiés pour cette raison essentielle que l'on est alors obligé de les poser dans la perspective de l'action et d'opérations effectuées matériellement avant de pouvoir être intériorisées sous une forme symbolique. Tant que le problème se situe au niveau de la pensée adulte élaborée, l'opposition de l'analytique et du synthétique s'appuie sur celle du 
langage (instrument de la constatation), entre lesquelles il n'y a ni filiation ni continuitée.

Tradução livre: Vemos então que pelo simples fato de colocarmos o problema do analítico e do sintético no terreno genético, os termos desse problema são profundamente modificados pela simples razão de sermos agora obrigados a colocá-los no contexto das ações e das operações efetuadas na empiria, antes que possam ser interiorizadas sob uma forma simbólica. Conseqüentemente, o problema no nível do pensamento adulto, já está elaborado e a oposição do analítico e do sintético se apóia na linguagem (instrumento do pensamento hipotético-dedutivo) e da percepção (instrumento da constatação), nos quais não há nem filiação, nem continuidade.

$\mathrm{Na}$ alternância do analítico / sintético segundo Piaget, no que diz respeito à ciência exata terminar-se-á no necessário e nas ciências biológicas, dizemos nós, terminará no freqüente estabelecido por Aristóteles e na classe citada por Granger, Popper e Piaget. Para nós, a Medicina Legal alcançaria exatamente esse nível conceitual.

Outros enunciados e proposições no âmbito da Medicina Legal, devido às suas origens na experiência, ou seja, na empiria, existem em grande quantidade. Além da possibilidade de emitirem-se juízos quer sejam analíticos ou sintéticos a priori ou não, na análise dos enunciados e proposições, deve-se também ao estudar-se as categorias em Kant, por analogia ao que se fez em relação às categorias em Aristóteles em texto acima, ver-se quais relações existem entre as categorias kantianas e o agir pericial no universo da Medicina Legal. Garcia Morente (1980:243), ao tratar da filosofia kantiana, especifica o que são as categorias na ótica de Kant. Advertimos que o trabalho deste filósofo diverge da abordagem aristotélica, pois o Estagirita trata das categorias na vertente realista, ou seja, fruto da experiência, enquanto o filósofo de Königsberg estabelece as categorias com substrato na Razão Pura. Escreve Morente:

Que significam estas categorias? Que sentido tem? Que função desempenham? Isto é o que Kant se propõe elucidar na parte da analítica transcendental que leva o nome de dedução transcendental das categorias. Esta passagem é provavelmente a mais famosa de toda obra de Kant. Das duas edições que fez Kant da Crítica da Razão Pura, esta passagem, que abrange grande número de páginas, foi na segunda edição completamente refeita, transformada por completo. Adverte-se muito bem, pelos esforços que custou a Kant sua redação, aquilo que hoje é bem sabido: que esta passagem constitui o núcleo essencial da Crítica da Razão Pura e é realmente a raiz mais profunda do pensamento kantiano... Kant se propõe a mostrar que as categorias são as condições da possibilidade dos juízos sintéticos a priori na Física; mas realmente seu propósito vai além. Propõe-se aqui explicar o fundo mesmo do seu pensamento filosófico. 

kantiano:

Coloquemos em destaque a última afirmação de Garcia Morente sobre o pensamento

Pois bem, seu pensamento filosófico, neste ponto essencial, acredito eu que se pode chegar a formulá-lo concisamente nesta frase que logo vou explicar: 'Que as condições do conhecimento são, ao mesmo tempo, as condições da objetividade' ou 'Que as condições do conhecimento são as mesmas que as condições da objetividade'.

A abordagem racionalista da filosofia é plenamente estabelecida em Descartes, atingindo seu cume em Leibniz, onde começa a transição para o idealismo. Kant completa, termina, consagra o idealismo, ao definir segundo Garcia Morente (1980:219) "como na relação do conhecimento, aquilo que chamamos ser é, não o ser "em si”, mas um ser objeto, um ser "para" ser conhecido, um ser posto logicamente pelo sujeito pensante e cognoscente, como objeto de conhecimento", encerrando ainda, na visão de Garcia Morente, uma etapa da história da filosofia que começara em Descartes e iniciando outra, a do idealismo transcendental e ao mesmo tempo, a Filosofia da Ciência.

Partindo-se da maiêutica socrática, passando-se pela dialética platônica, pela lógica aristotélica, pela leitura cristã e clássica de Aristóteles na escolástica, chegando-se ao método na visão cartesiana do mundo, aporta-se na crítica da Razão em Kant. Périplo este, que fundamenta o pensar humano quando se trata do conhecimento, especificamente, científico.

A ciência em Kant, explicaria o visum et repertum, da tradição médico-legal? Ora, nessa tradição, a observação de um fenômeno (lesão ou doença) originado por energias vulnerantes, ou seja, energias de origens externas ao homem devem produzir relatos verdadeiros (no sentido do veritas), que possam ser demonstrados e falseados no sentido popperiano do termo.

Onde freqüentemente se assesta o visum et repertum do agir pericial nos domínios da Medicina Legal quando se tem em mente relações do tipo sujeito/objeto, analítico/sintético, saberes técnico-científicos, ou, melhor ainda, especificando melhor, Razão/Entendimento?

Observem-se as diferenças entre a Razão (Vernunft) e Entendimento (Verstand) na ambiência filosófica de Kant. A Razão teria como objeto o "vir a ser", o "tornar-se”, ou seja, o movimento ininterrupto atuante como uma lei geral no universo, que estabelece juízos e assim, muda e transforma as realidades existentes. O Entendimento teria por objeto aquilo que já está estabelecido pelos juízos anteriores, é expressão temporal do presente, enquanto a 
Razão estaria voltada para o futuro. Enquanto a Razão não se colocaria preocupada com o destino, pois este está para ser estabelecido, o Entendimento vivendo no presente, não se ocupa com as origens, aquela vive no desdobrar das coisas e este no assimilar tudo para poder utilizá-lo.

O agir pericial vive mais do Entendimento que da Razão, consolidado na verdade que desvenda que revela que expõe as realidades e afasta o falso, (portanto, na Aletheia), deve traduzir a realidade de fatos biológicos fruto de ações externas em textos que manifestem a Veritas, ou seja, relatos verdadeiros de fatos ou fenômenos passados. O agir pericial ainda deve relacionar os dados obtidos dos eventos a conceitos; isso não sendo possível, deverá, pelo menos, estabelecer inferências, quiçá, implicações, pois a necessidade demonstrativa deve permear o referido agir. No trato da coleta de dados, na interpretação dos mesmos, na inserção em uma classe, no recurso à plasticidade das noções fruto do olhar particular sobre os eventos, que deverá daí migrar por via estrutural, para as totalidades e auto-regulações no sentido piagetiano do termo, pois o agir pericial deve nortear-se por sistematizações, que permitam a díade Razão/Entendimento justificar o agir do perito.

As categorias, em Kant, constituem o cerne da dedução transcendental, ou seja, o fulcro do pensamento kantiano na Crítica da Razão Pura. Essa crítica significa, antes de mais nada, uma análise da própria Razão para determinar quais são as suas possibilidades de conhecimento do mundo. Nos textos acima se abordou as categorias em Aristóteles, que tinham a mesma intenção, sem o caráter de necessidade que aparecerá em Kant, graças à

\section{dedução transcendental.}

Impõem-se então a devida relação dos enunciados e temas da Medicina Legal com estas categorias que constituem os fundamentos e as possibilidades da Razão através dos juízos, como diz Kant e que permitirão o uso do Entendimento, repitamos, que levará ao conhecimento do real, ou daquilo que ocorre.

As referidas categorias do pensar, estabelecidas pelo filósofo de Königsberg, estão evidenciadas na Analítica Transcendental, onde ele analisa os conceitos e a seguir os princípios do entendimento puro. Kant (1994: 97) assim define a sua analítica: 
pertençam à intuição nem à sensibilidade, mas ao pensamento e ao entendimento. 3. Que sejam conceitos elementares e sejam bem distintos dos derivados ou dos compostos de conceitos elementares. 4. Que a sua tábua seja completa e abranja totalmente o campo do entendimento puro. Ora, esta integral perfeição de uma ciência não pode ser aceita com confiança se assentar apenas sobre o cálculo aproximativo de um agregado, obtido por simples tentativas; daí que seja somente possível mediante uma idéia da totalidade do conhecimento a priori do entendimento e pela divisão, determinada a partir dessa idéia, dos conceitos que o constituem, por conseguinte pela sua interconexão num sistema. $O$ entendimento puro distingue-se totalmente não só de todo o elemento empírico, mas também de toda a sensibilidade. É, pois, uma unidade subsistente por si mesma e em si mesma suficiente, que nenhum acréscimo do exterior pode aumentar. Daí que o conjunto do seu conhecimento constitua um sistema, a abranger e determinar por uma idéia, sistema cuja perfeição e articulação possam oferecer, ao mesmo tempo, uma pedra de toque da exatidão e genuinamente de todos os conhecimentos que nele se incluam. Toda esta parte da lógica transcendental é constituída por dois livros, dos quais o primeiro contém os conceitos e o outro os princípios do entendimento puro.

É importante ressaltar que os termos puro e a priori, em Kant, são usados no mesmo sentido, ou seja, aquilo que precede a todo conhecimento possível. No entender atual, como vimos nos textos de biólogos, significariam o funcionamento cerebral, ou ainda os processos do funcionamento do cérebro que têm a missão de interpretar a realidade.

Em diversas situações amiúde freqüentes, a vivência pericial é contaminada por fatores externos ao evento ou fenômeno. Foi afirmado em textos acima que inúmeros agentes aí podem interferir, ou seja, o aparato policial (quando se estiver diante de agentes despreparados), a situação do fato, as emoções advindas do evento propriamente dito, as pressões sociais advindas da exposição midiática excessiva, os prazos estabelecidos pelos agentes judiciários e ainda as incertezas inerentes a maior ou menor complexidade do evento ou dos eventos particulares envolvidos. Nestas situações, especialmente quando a carga emocional é muito grande o agir pericial se complica, existindo como solução a díade Razão/Entendimento do pensar kantiano, que possibilita o pensar científico e restabelece a condição técnico-científica. Para Kant, há uma função lógica do Entendimento, dos Juízos e o primeiro não é uma faculdade da intuição, sim, um conhecimento por conceitos, portanto, discursivo.

O juízo seria então o conhecimento mediato do objeto e a função, a unidade da ação que ordena diversas representações sob uma representação comum. Estes conceitos kantianos do pensar estão soberbamente alinhados na denominada função lógica do entendimento dos 
juízos, ou seja, as categorias. Kant (1994: 104) adverte sobre a abstração do juízo geral para atender-se à forma do Entendimento, do seguinte modo: "Juízos segundo a Quantidade: universais, particulares e singulares; Juízos segundo a Qualidade: afirmativos, negativos e infinitos; Juízos segundo a Relação: categóricos, hipotéticos e disjuntivos; Juízos segundo a Modalidade: problemáticos, assertórios e apodíticos."

O juízo em Kant estabelece, põe, assenta a realidade, assim esta realidade estaria contida nos juízos acima referidos e, desta forma, seria suficiente buscar-se em cada forma dos diversos juízos a forma correspondente da realidade, ou seja, daquilo que é concreto e evidente, para se ter a "Tábua das Categorias" na visão kantiana da mesma realidade. Esta tábua das categorias está nas páginas 110/111 da Crítica da Razão Pura (1994):

Da quantidade: unidade, pluralidade, totalidade

Da qualidade: realidade, negação, limitação

Da relação: inerência e subsistência (substantia et accidens), causalidade e dependência (causa e efeito), comunidade (ação recíproca entre $o$ agente e o paciente).

Da modalidade: possibilidade - impossibilidade, existência - não existência, necessidade - contingência. Esta é, pois a lista de todos os conceitos, originariamente puros, da síntese que o entendimento a priori contém em si, e apenas graças aos quais é um entendimento puro; só mediante eles pode-se compreender algo no diverso da intuição, isto é, podese pensar um objeto dela. Esta divisão é sistematicamente extraída de um princípio comum, a saber, da faculdade de julgar (que é o mesmo que a faculdade de pensar) e não proveniente, de maneira rapsódica, de uma procura de conceitos puros, empreendida ao acaso e cuja enumeração, sendo concluída por indução, nunca se pode saber ao certo se é completa, sem pensar que desse modo nunca se compreenderia porque são esses e não outros os conceitos inerentes ao entendimento puro. A procura destes conceitos fundamentais foi empresa digna de um espírito tão perspicaz como o de Aristóteles.

A partir das categorias em Kant que se sabe constitui o cerne da Crítica da Razão Pura, considerando-se ainda a tipologia dos juízos referenciados acima, pode-se fazer a ligação entre os juízos e as categorias em uma tábua mista, onde a classificação dos juízos na lógica formal, devido à faculdade do julgar e, portanto, do pensar, são atributos destes, e então ir-se dos juízos às categorias na seguinte tabela mista:

Da quantidade

Juízos Categorias 


$\begin{array}{lll}\text { Universais } & - & \text { Totalidade } \\ \text { Particulares } & - & \text { Pluralidade } \\ \text { Singulares } & - & \text { Unidade }\end{array}$

Da qualidade

\begin{tabular}{lcl} 
Juízos & \multicolumn{3}{c}{ Categorias } \\
Afirmativos & - & Realidade \\
Negativos & - & Negação \\
Infinitos & - & Limitação \\
\multicolumn{1}{c}{ Da relação } & \\
Juízos & & Categoria correlativa \\
Categóricos & - & Inerência e subsistência \\
Hipotéticos & - & Causalidade e dependência \\
Disjuntivos & - & Comunidade (reciprocidade)
\end{tabular}

Da modalidade

$\begin{array}{llc}\text { Juízos } & & \text { Categorias positiva e negativa } \\ \text { Problemáticos } & - & \text { Possibilidade }- \text { Impossibilidade } \\ \text { Assertórios } & - & \text { Existência }- \text { Não existência } \\ \text { Apodíticos } & - & \text { Necessidade - Contingência }\end{array}$

Diante desta Tabela mista dos juízos e das categorias em Kant, urge adentrar, ainda que superficialmente, ao que entendo ser o pensamento kantiano sobre o mundo fenomênico, derivando este entendimento de estudo acurado deste pensar na ótica do filósofo, antes de se fazer referência às possibilidades de se estabelecer relações entre os enunciados da Medicina Legal e as referidas categorias kantianas e antes também de torná-las claras para o perito por intermédio de um método que contenha regras, como pretenderam tantos. Cada médicolegista adentrará a teoria o quanto queira, ou o quanto a sua curiosidade o solicite. Nosso intuito é deixar um caminho estabelecido para o estudioso de Medicina Legal nas faculdades de Medicina, ou da Medicina Forense, nas faculdades de Direito, tirando o estudioso, o quanto possível, do "empirismo ingênuo" que tantos danos têm causado à prática dos peritos, dominada pelos laudos incompletos, contraditórios em si mesmos e danosos à nossa 
sociedade possibilitando condenações injustas e não punição de culpados. Assim, acreditamos como tantos já disseram, teoria e prática deveriam sempre andar juntas.

Tem-se visto que o fenômeno não é outra coisa que o estado (aqui visto como uma das categorias aristotélicas) do dado sensível sob as formas espaciais e temporais. Por sua substância (a principal categoria em Aristóteles, ou seja, conjunto de atributos que identificam e nos permitem dizer "isto é a ou b" ) aqui, simples impressão atual passivamente recebida, o fenômeno se acha recluso nas mais estritas condições da particularidade local e temporal.

Conseguiria o fenômeno escapar destas condições ao menos por sua forma? A resposta é negativa, a extensão (enquanto conceito do dualismo cartesiano que separa a substância pensante da substância extensa, ou seja, enquanto objeto do conhecimento) ou a sucessão (como expressão representativa da temporalidade intuitiva kantiana), enquanto afetam o dado não ultrapassam os limites deste ou daquele dado particular. A forma de cada fenômeno, mesmo resultando de uma situação mais geral, contrai-se e então se particulariza ao unir-se a uma determinada matéria particular. Assim sendo, é o caráter particular do fenômeno que o impede de se objetivar em nossa consciência. A cada instante, a cada átimo de tempo, diante de um fenômeno, nossa capacidade cognoscitiva é afetada extrinsecamente, vive, recebe influência enquanto estado, e não como objeto, pois não se consegue separar tal situação da nossa subjetividade.

Se o fenômeno é, ou constitui-se de dados recebidos e percebidos em nossa consciência, isto pode significar que podemos ser modificados por eles; nesta condição, a passividade e a subjetividade se encontram e convivem; uma implica a outra (atente-se para o papel da implicação no sentido piagetiano do termo, ou seja, "centro do processo cognitivo").

Para se conhecer o fenômeno objetivamente, dever-se-ia começar por isolá-lo das condições de uma receptividade presente e particular que o ligam à minha consciência como um sujeito contingente que com ele se confunde porque o objeto não pode ser conhecido senão em oposição e ao mesmo tempo em relação ao sujeito. Porém, estando o fenômeno aderido à minha subjetividade, para que se consiga uma separação no interior desta unidade indistinta do "eu" e do "não eu" devem-se impor novas condições ao fenômeno, que não sejam apenas compatíveis com a subjetividade presente. Estas novas condições da 
representação fenomênica não podem vir de um ou mais dados externos adicionados ao que já possuo, porque se fossem recebidas puramente de fora, seriam particulares e subjetivas como a mesma representação fenomênica original. Devem provir, no entanto, se tudo isto é possível, da espontaneidade da capacidade cognoscitiva dos processos mentais, ou seja, do encéfalo humano.

Todo dado recebido através de um processo cerebral, se reveste, queiramos ou não, de uma forma receptiva, ou seja, do mesmo processo mental, constituindo-se assim na unidade mais elementar que pode ocupar a consciência, ou seja, o fenômeno. Kant (1994: 172) quando trata, na Analítica dos Conceitos, dos fenômenos, enuncia o seguinte:

Na verdade como fenômenos constituem um objeto que está simplesmente em nós, pois uma simples modificação da nossa sensibilidade não se encontra fora de nós. Ora, esta representação mesma exprime que todos estes fenômenos, portanto todos os objetos com os quais nos podemos ocupar estão todos em mim, isto é, esta representação exprime, como necessária, uma unidade completa dessas determinações numa só e mesma apercepção. Porém, é nesta unidade da consciência possível que consiste, também, a forma de todo o conhecimento dos objetos (pelo qual o diverso é pensado como pertencente a um objeto). $\mathrm{O}$ modo, pois, como o diverso da representação sensível pertence a uma consciência, precede todo o conhecimento do objeto, como forma intelectual deste, e ele próprio constitui um conhecimento formal a priori de todos os objetos em geral, na medida em que são pensados (categorias).

É possível conceber-se uma "consciência" (sensu lato) sem as "categorias"? Tal situação seria possível na ótica kantiana se a mesma não fosse "objetiva”. Sendo assim, os dados iniciais aos quais se aplica a "Crítica", não se reduzem a puros fenômenos da sensibilidade, representam, quando em conjunto, todos os atributos do que se pode denominar de "objetos fenomênicos". A consciência cujos processos devemos conhecer e controlar, não é uma consciência qualquer, mas uma consciência objetiva.

Ao tomar consciência de um fenômeno, (“objeto", "evento", "situação" etc.) confiro a qualquer um deles uma unidade independente, possibilito relações com minhas faculdades cognoscitivas, atribuo-lhes permanência e relações, revisto-os de predicados quiçá universais e necessários, por isto, incompatíveis com o caráter particular e passível de modificação subjetiva. Um evento, como uma lesão produzida por agente vulnerante como o "calor", provocando queimadura de $3^{\circ}$ grau, ao ser examinado, ou seja, ao ser avaliado pelo perito, é como uma realidade, como o "eu" mesmo, e não somente uma simples alteração desse "eu". Por mais que o agir pericial, formule um juízo na visão kantiana, ou seja, "determine e ponha 
a realidade", sua constituição advém de leis físicas necessárias, ele existe no espaço e no tempo (atente-se aqui aos conceitos kantianos de tempo enquanto intuição interior e também exterior e o espaço, intuição exterior), está submetido aos conceitos de causalidade, de substancialidade, de materialidade jurídica, deixou de ser um puro fenômeno, um momento inconsistente de minha consciência, para situar-se como "objeto de experiência", com suas leis próprias, igualmente concebíveis e fora, portanto, de toda relação com minha subjetividade atual.

O fenômeno para passar, na consciência, do estado de impressão subjetiva ao estado de objeto do conhecimento deve adquirir propriedades que estruturem a relação do momento presente e a situação peculiar que o origina, deve universalizar-se de alguma maneira.

Ao fundamentar-se o "universo fenomênico de Kant" nas mais recentes aquisições das Neurociências, especialmente quando se estudam as funções complexas do encéfalo, percebese o quão atinentes à ciência foram as assertivas do filósofo referenciadas nos textos desta Tese. Purves (2005: 565), ao dissertar sobre "os córtices associativos", mostra cabalmente o que acabamos de afirmar. Escreve ele:

Os córtices associativos incluem a maior parte da superfície cerebral do encéfalo humano e são grandemente responsáveis pelo processamento complexo que ocorre entre a chegada de sinais nos córtices sensoriais primários e a produção do comportamento. As diversas funções dos córtices associativos são referidas de modo não muito preciso como "cognição", que significa literalmente o processo pelo qual nós tomamos conhecimento do mundo ("cognição" talvez não seja a melhor palavra para indicar essa ampla gama de funções neurais, mas já se tornou parte do vocabulário de trabalho de neurólogos e neurocientistas). Mais especificamente, a cognição refere-se à capacidade de prestar atenção a estímulos externos ou motivação interna, de identificar o significado de tais estímulos e de planejar respostas significativas para eles. Em função da complexidade de tais tarefas, não é surpreendente que os córtices associativos recebam e integrem informação de uma variedade de fontes e que influenciem uma ampla gama de alvos corticais e subcorticais. Sinais de entrada para os córtices associativos incluem projeções dos córtices sensoriais e motores primários e secundários, do tálamo e do tronco encefálico. Sinais de saída dos córtices associativos alcançam o hipocampo, os gânglios da base e o cerebelo, o tálamo e outros córtices associativos. Vislumbres de como funcionam as áreas associativas vieram primeiramente de observações de pacientes humanos com lesão em uma ou outra dessas regiões. Técnicas não-invasivas de imageamento cerebral de sujeitos normais, mapeamento funcional durante neurocirurgias e análise eletrofisiológica de regiões comparáveis do encéfalo em primatas não-humanos tem geralmente confirmado essas impressões clínicas. Juntos, esses estudos indicam que, entre outras funções, o córtex associativo parietal é especialmente importante para a percepção de estímulos complexos nos 
ambientes externo e interno, que o córtex associativo temporal é especialmente importante para a identificação da natureza de tais estímulos e que o córtex associativo frontal é especialmente importante para o planejamento de respostas comportamentais adequadas para os estímulos.

Ao estudarem-se as "categorias do entendimento", em Kant, percebe-se que os "objetos de consciência" que podem ser chamados de "objetos de experiência", são aqueles cujos conhecimentos sistemáticos constituem a Física, enquanto ciência da natureza, pois o universo kantiano era bem diverso em ciência e complexidade na relação com o mundo da Biologia de então. Atente-se aqui, ao referenciado acima, quando se fala das funções complexas do encéfalo humano e mais especialmente dos "córtices associativos" e veja-se a assertividade do pensar kantiano, mesmo para a nossa época.

Os juízos que manifestam estes atributos pretendem uma universalidade que certamente não pode ter seus princípios adequados em nenhum dado particular. Veja-se, pois, as "formas" possíveis e acima referidas destas categorias, à luz destas proposições abaixo mencionadas, inspiradas na Lógica Transcendental kantiana:

X é Y
X não é Y
X é Y ou Z
Se X é, Y é

O juízo categórico afirmativo (1) reúne, de maneira decisiva, uma forma $\mathrm{Y}$ a um sujeito X. Feita a abstração de toda diversidade de matéria, este juízo expressa a realidade do sujeito e do predicado, segundo uma relação de inerência do predicado ao sujeito.

O juízo categórico negativo (2) separa da realidade esta mesma relação de inerência, colocando-se na forma indefinida $\mathrm{X}$ não é $\mathrm{Y}$, afirma-se de $\mathrm{X}$ a realidade de um atributo caracterizado pela limitação, ou seja, pela exclusão do termo $Y$.

O juízo disjuntivo (3) estabelece uma ligação de comunidade (relação recíproca agente paciente), exclusiva ou não, entre cada um dos termos $\mathrm{Y}, \mathrm{Z}$ e X.

O juízo hipotético (4) manifesta uma dependência não recíproca de Y com relação a X, expressa a causalidade sensu stricto. 
Se estabelecermos que estas diferentes proposições, por uma diversidade qualquer, podem ser já Universais, Singulares e Particulares, e por fim, que a modalidade da afirmação julgadora, para um conteúdo qualquer, pode expressar-se seja por um "talvez" (juízos problemáticos), ou por um "isto é a ”" (juízos assertórios), seja por um "dever ser” (juízos apodíticos), se terá desenhado toda a diversidade do que são capazes os juízos, abstraída sua matéria, conteúdo; o que Kant quer é estabelecer todas as formas puras da síntese da função de julgar.

O filósofo chama de conceito puro do entendimento, as formas a priori da síntese dos fenômenos em "objetos".

Haverá então tantos conceitos puros, ou seja, a priori, quantas funções de julgar, sintéticas, existirem. Há assim, uma coincidência entre conceitos puros e formas sintéticas do juízo. As regras gerais acima referidas que se aplicam aos juízos, estabelecem aprioristicamente outras tantas sínteses da diversidade fenomênica. O conceito puro do entendimento é, na ótica kantiana, uma forma sintética a priori dos fenômenos.

A refinada construção de tipos fundamentais como os "conceitos puros", "funções do julgar", os diversos tipos de "juízos", possibilitou a Kant, chegar às "categorias" e à dedução transcendental das mesmas.

O objetivo da "dedução transcendental" é explicar de que maneira os conceitos apriori podem referir-se aos objetos, ou ainda, sob quais condições apriori são possíveis os objetos na consciência.

A Medicina Legal, ciência fundamentada na Biologia, é vivenciada na conjuntura social que busca, sob a égide da Justiça, orientar os operadores do Direito e contribuir para uma sociedade mais justa e ordenada, necessitaria a nosso ver, a demonstração epistemológica de sua adaptação conceitual dos fenômenos às categorias kantianas; e por uma razão muito simples: não existe outra teoria que esmiúce tão adequadamente as possibilidades de raciocinar, levando-se em conta a realidade. As tabelas da Lógica demonstraram as possibilidades do estabelecimento dos juízos, mas apenas formalmente, sem levar em conta, por sua própria natureza, espaço, tempo e causalidade. Ora, sem a inclusão desses aspectos, não existiria ciência da natureza, estar-se-ia restrito a um raciocínio sem referente no mundo, ou seja, à Lógica e à Matemática. Os modelos lógico-matemáticos da Física, da Química e, 
hoje em dia, também da Biologia, devem necessariamente aplicar-se ao mundo concreto, físico e social. A Física nasceu antes de Kant, mas foi ele quem desvendou sua possibilidade de existência, daí sua pergunta tão famosa: como é possível a Física?

Os fenômenos estudados na Medicina Legal estão localizados essencialmente no corpo humano, corpo humano este enquanto estrutura (no sentido piagetiano do termo), que vai do micro ambiente ao macro ambiente e vice-versa. Fenômenos estes originados, oriundos, da ambiência externa, ou seja, devidos a ações de energias vulnerantes sensu lato, ou a situações peculiares advindas de respostas biológicas concretas produzidas por estimulações como os denominados "traumas psicológicos". A Medicina Legal ainda estuda os fenômenos biológicos ditos "naturais", como a morte, o nascimento, os compromissos sociais como o casamento, separação, divórcio, as ocupações jurídicas como a prova, o local de crime, a identidade sob a ótica biológica e jurídica, e tantos outros temas já referenciados acima. As possibilidades fenomênicas, portanto, são quase infindáveis. A escolha de fenômenos que tipifiquem exemplos da "quantidade dos juízos" nas categorias de: unidade, pluralidade e totalidade na ambiência da Medicina Legal é estabelecida a partir daquilo que se pode afirmar de uma coisa singular, ou seja, contém no seu íntimo a "unidade". Sob este viés, a lesão "pessoal”, no dizer, tanto de Flamínio Fávero quanto de Genival Veloso de França, ou ainda, a lesão "corporal”, do Código Penal, é "coisa singular", pois, ao examinar-se tal lesão em uma determinada pessoa, está-se diante da "unidade" enquanto categoria do entendimento, pois a representação física daquela lesão é peculiar ao indivíduo. Se de várias coisas se afirma algo, ou seja, ao emitirem-se juízos particulares, fica-se diante da categoria da "pluralidade". Ao levar-se em consideração aquilo que diz respeito a alguns indivíduos indeterminados de uma “classe", vê-se a "pluralidade". Quando o perito examina um grupo de lesões portadas por diversas pessoas que apresentam os seguintes sinais, por exemplo: escaras secas de aparência nacarada, presentes na face e no pescoço de alguém, escaras secas de cor amarelada, presentes na face e tórax de outra pessoa, escaras úmidas e untuosas na face de uma terceira pessoa, podemos dizer que foram vítimas de "vitriolagem" podendo-se afirmar a categoria da pluralidade como presente. Kant deixa claro que os juízos universais têm em seu seio a "totalidade". Desta forma, vítimas de um determinado evento onde todas sem exceção foram carbonizadas requerem do entendimento do perito o conceito da "totalidade". A totalidade enquanto conjunto definido remeter-nos-ia à singularidade; este entrelaçar-se de conceitos nos 
juízos e nas categorias kantianas, nos propicia um conjunto representado pela figura geométrica da "esfera" onde as partes não se superpõem, mas, juntas formam a "totalidade".

Sob o ponto de vista da "qualidade", Kant estabelece o juízo afirmativo e sua correspondente categoria à "realidade". De uma coisa, objeto etc. pode-se afirmar "é isto", por exemplo: "a pistola é uma arma", está estabelecida a relação sujeito/predicado e por consequiência, a "realidade". Nas categorias da "qualidade" a referência kantiana é a "essência", ou melhor, ainda a "substância". O juízo negativo separa do sujeito a inerência com o predicado, ou seja, "X não é Y". A negação exclui a inerência, ou seja, o Y. Por exemplo: "esta mulher não é virgem”. O juízo infinito na ótica kantiana expressa aquilo que algo não é, porém deixa possibilidades infinitas de que seja outra coisa, somente limita o sujeito, portanto, traz à luz a categoria da "limitação". Por exemplo: "a radiação ionizante não é inócua ao ser humano".

Quando aborda as categorias da relação, Kant (1994: 106) diz: "Todas as relações do pensamento nos juízos são: a) do predicado com o sujeito, b) do princípio com sua consequiência, c) do conhecimento dividido e de todos os membros da divisão entre si. Na primeira espécie de juízos consideram-se só dois conceitos, na segunda, dois juízos, na terceira, vários juízos nas suas relações recíprocas." Têm-se então os juízos categóricos, hipotéticos e disjuntivos, seguidos das categorias correlativas: inerência e subsistência (substantia et accidens), causalidade e dependência (causa e efeito), comunidade (ação recíproca entre o agente e o paciente).

Dos juízos categóricos Kant estabelece a categoria correlativa de "inerência e subsistência”, ou seja, a substância e o complemento, relação sujeito/predicado, ou ainda, conjunto de atributos que unem o predicado ao sujeito. $\mathrm{O}$ perito ao afirmar: "o instrumento que produziu lesão de bordas regulares, que apresenta cauda escoriativa que se superficializa é de natureza cortante", estabelece a categoria de "inerência e subsistência". Dos juízos hipotéticos deriva a categoria da "causalidade e dependência". Quando o perito formula enunciado como: "se existe um quadro clínico de hemorragia interna neste caso foi devido à ruptura hepática e laceração do hilo pulmonar direito", estabeleceu-se a causalidade e o seu complemento, a dependência. Dos juízos disjuntivos Kant formula a categoria de "comunidade" (Gemeinschaft). Tal noção aparece no quadro das categorias, acima referenciadas, ainda nas "Analogias da Experiência" e por fim na Metafísica dos Costumes. 
Aparece esta categoria quando o "entendimento" formula "juízos disjuntivos", ou seja, a coexistência das partes em um todo. Assim se manifesta Kant (1994: 114/ 115):

Temos que observar que, em todo juízo disjuntivo, a esfera (o conjunto de tudo que está contido neste juízo) é representada como um todo dividido em partes (os conceitos subordinados); não podendo estar uma dessas partes contida na outra, são pensados como coordenadas uma à outra, não como subordinadas, pelo que se não determinam entre si num só sentido, como numa série, mas reciprocamente, como num agregado (quando se põe um membro da divisão, todos os outros são excluídos e inversamente). Quando se pensa, pois, semelhante ligação num todo de coisas, uma não será subordinada, enquanto efeito, à outra, enquanto causa da sua existência; antes é simultânea e reciprocamente coordenada às outras coisas como causa no que se refere à sua determinação (como, por exemplo, num corpo cujas partes se atraem e repelem reciprocamente); relação essa que constitui uma espécie de ligação muito diferente da que se encontra na simples relação de causa e efeito (do princípio à consequiência), na qual a consequiência não determina reciprocamente o princípio e, portanto não constitui com este um todo (como o criador do mundo com o mundo). Este processo, que segue o entendimento, quando representa a esfera de um conceito dividido, é o mesmo que ele observa quando pensa uma coisa como divisível; e tal como no primeiro caso, os elementos da divisão se excluem reciprocamente, embora ligados numa esfera, assim também, no segundo caso, ele representa as partes dessa coisa como partes cuja existência (como substâncias) convém a cada uma com exclusão das restantes e, todavia, como ligadas num todo.

A noção de comunidade (Gemeinschaft) em Kant merece um prolongamento reflexivo, devido à sua real importância científica. As Analogias da Experiência se reportam ao modus operandi das nossas percepções quando representa em nós mesmos um universo, a permanência das essências, o caráter aleatório das mudanças, o evoluir no curso do tempo e finalmente o conviver num determinado espaço. "Todas as substâncias, enquanto susceptíveis de ser percebidas como simultâneas no espaço, estão em ação recíproca universal." (Kant 1994: 232). A prova estabelecida pelo filósofo deste princípio base da terceira analogia da experiência fica melhor esclarecida no Princípio da Comunidade: “Todas as substâncias, na medida em que são simultâneas, estão em comunidade universal (isto é, num estado de ação recíproca). Princípio este definido por Kant, na segunda edição da Crítica da Razão Pura. Para o filósofo a palavra “comunidade” é definida da seguinte forma. (Kant 1994: 234/235):

A palavra Gemeinschaft (comunidade) tem dois sentidos na língua alemã e tanto pode significar communio como commercium. Servimo-nos dela neste último sentido, como comunidade dinâmica, sem a qual a comunidade local (communio spatii) nunca poderia ser conhecida empiricamente. Facilmente se observa, nas nossas experiências, que só as influências contínuas em todos os lugares do espaço podem conduzir o nosso sentido de um objeto para outro; que a luz que atua entre nossos olhos e os corpos do mundo pode 
efetivar uma comunidade mediata entre nós e esses corpos, provando, desse modo, a simultaneidade dos últimos; que nós não podemos mudar empiricamente de lugar (perceber essa mudança), sem que, por toda a parte, a matéria nos torne possível a percepção do nosso lugar e que só mediante a sua influência recíproca é que a matéria pode provar a sua simultaneidade e, desse modo (embora de maneira apenas mediata), a coexistência dos objetos, mesmo os mais distantes. Sem comunidade, toda a percepção (do fenômeno no espaço) está separada das outras e a cadeia das representações empíricas, ou seja, a experiência começaria desde o princípio em cada novo objeto, sem que a precedente pudesse estabelecer com ela a mínima ligação ou encontrar-se com ela numa relação de tempo. Para esclarecimento pode servir o seguinte: todos os fenômenos, no nosso espírito, enquanto incluídos numa experiência possível, tem de encontrar-se em comunidade (communio) de apercepção, e para que possam ser representados como ligados, existindo simultaneamente, tem que determinar reciprocamente o seu lugar num tempo e constituir, desta sorte, um todo. Mas para que esta comunidade subjetiva assente num fundamento objetivo, ou se refira aos fenômenos como substâncias é necessário que a percepção de uns torne possível como fundamento, a possibilidade da percepção dos outros e, reciprocamente, para que a sucessão, que está sempre nas percepções como apreensões, não seja atribuída aos objetos, mas que estes possam ser representados como simultaneamente existentes. Isto, porém, é uma influência recíproca, ou seja, uma comunidade (commercium) real das substâncias, sem a qual não poderia verificar-se na experiência a relação empírica da simultaneidade. Mercê deste comércio, os fenômenos, na medida em que estão fora uns dos outros $\mathrm{e}$, contudo, em ligação, constituem um composto (compositum reale), e tais compostos são possíveis de diversas maneiras. As três redes dinâmicas, donde todas as outras procedem são, pois, as de inerência, de conseqüência e de composição.

No universo da Medicina Legal, onde transitam diversos temas, em sua maior parte independentes uns dos outros, em outras situações com interdependência, em ainda outras fazendo ligações, encontram-se fenômenos que habitam na terceira categoria das relações, ou seja, na "comunidade". Temas como: divórcio, herança parental, lesão corporal, por exemplo, são independentes. No entanto, lesões corporais e agentes vulnerantes são interdependentes, enquanto aborto e infanticídio se ligam e promovem interações com outras áreas do temário médico-legal. Todo o universo temático da Medicina Legal é um todo dividido em partes pensadas como coordenadas entre si, não subordinadas, por não estarem determinadas em um único sentido, não se comportam como uma série, mas reciprocamente como um agregado que implica relações. Obedece, portanto, ao Princípio da Comunidade defendido por Kant e citado acima.

É preciso que se diga, para deixar bem claro, que aqui reside uma importantíssima explicação da idéia de causalidade. O texto de Kant revela de maneira clara a crítica falaciosa da qual foi vítima o filósofo ao ser acusado de separar radicalmente sujeito e objeto do 
conhecimento. Percebe-se, com certa facilidade, que ele demonstra o contrário, pois, em muitos casos: A só pode ser causa de B, porque B é susceptível de ser consequiência de A. Asssim, A e B formam um todo de influências recíprocas, de trocas sempre interdependentes, graças ao princípio que ele denominou: princípio da comunidade.

$\mathrm{Na}$ abordagem da modalidade, Kant expressa nesta categoria o "talvez", como referência básica dos juízos problemáticos; o "isto é a", como expressão dos juízos assertórios, e o "dever ser" como norte dos juízos apodíticos. Como nos explica muito bem Garcia Morente (1980: 243), “da quarta maneira de dividir os juízos extrai Kant as seguintes categorias: dos juízos problemáticos (A pode ser B), extrai a categoria de possibilidade; dos juízos assertórios (A é efetivamente B), extrai a categoria de existência; dos juízos apodíticos (A tem que ser B), extrai a categoria de necessidade. Temos então completa a tabela das categorias." A possibilidade dentro da Lógica Clássica é produzida através da indução, e nos remete na ambiência da Medicina Legal, às situações onde pontua a dúvida, ou seja, afirmação positiva com o receio do erro. Ao examinar-se mulher com os sinais clínicos do puerpério, porém, não se encontrar o recém nascido, está-se diante das possibilidades de aborto, natimorto, infanticídio, etc. nesta mesma circunstância haverá necessidade de se provar, após estudo acurado que estamos efetivamente diante de um infanticídio, por exemplo. A existência desta afirmação será comprovada quando os atributos que identificam esta situação forem estabelecidos. Houve, portanto, a separação diagnóstica do infante nascente, do infante nascido, do recém nascido, do natimorto; examinou-se a vítima e a agente do evento, estudado todo o fenômeno pode-se afirmar "isto é um infanticídio", a categoria da existência está definida.

Há ainda que se estudar as categorias negativas, quais sejam: a impossibilidade, a não-existência, a contingência, no universo da Medicina Legal. Ao examinar-se cadáver encontrado em meio aquoso, que apresenta unicamente os sinais externos da permanência naquele meio, está estabelecida a impossibilidade de afogamento como causa mortis. A não existência como categoria negativa, simplesmente nega o "isto é â", portanto, nega a substância (conjunto de atributos que identificam), não se percebendo os sinais clínicos e laboratoriais do infanticídio, se estabelece a categoria da não existência, em oposição ao definido acima como infanticídio. A contingência que permite a existência ou não de algo, é o não necessário, se opõe, portanto, ao "dever ser", no sentido de "ser necessariamente". Se o 
perito ao examinar uma vítima encontra lesão de características dúbias, não podendo classificá-la, a contingência está presente, cabe ao perito envidar esforços, para afastando a contingência chegar ao necessário, ou seja, fazer ciência.

As categorias em Kant determinam o ápice das possibilidades do "Entendimento", especialmente na ambiência da ciência. Ao tratar da comunidade científica ou ainda do pensamento científico a teoria kantiana, no que diz respeito aos juízos advindos de uma “consciência objetiva” estabelece que a busca da perfeição em cada ato, o evoluir constante, portanto, a "arethé" aristotélica em uma determinada área do saber, permite que outros, ali possam incursionar e assim se perprete o commercium de idéias e se possa gerar a "especialidade". O termo especialidade é muito caro à ciência médica nos dias correntes, no entanto, quando o universo referido é a Medicina Legal, não se pode falar deste termo, tal é a diversidade da qual ela é revestida.

A Medicina Legal é ciência na acepção da Filosofia das Ciências, e não especialidade médica, consubstanciada que está nos fundamentos epistemológicos referenciados nesta Tese.

Kant ensina que todo conhecimento inicia-se na experiência, mas, dela não deriva. Afirma que a unidade mais elementar da consciência é o fenômeno. Determina que o valor objetivo das categorias como conceitos a priori é tornar possível a experiência, enquanto, forma do pensamento. Como se proceder então à "leitura da experiência" na visão piagetiana do termo, como maneira de se juntar o referido pensar kantiano do fenômeno ao universo de uma Epistemologia da Biologia, que fundamentaria a Doutrina médico-legal em sua práxis? Este é o desafio a ser perseguido nas próximas páginas.

A "leitura da experiência" no sentido piagetiano do termo é por ele estabelecida, no sentido teorético da mesma assertiva, ou seja, abordada pelo filósofo e biólogo suíço, como expressão científica do/s fenômeno/s interpretada à luz do "ambiente endógeno", ou seja, o encéfalo humano, enquanto funcionamento cerebral. No entanto, a referida "leitura" foi vivenciada e profundamente estudada por outros filósofos como, por exemplo, Descartes (1596-1650) 2007:54/57) ao tratar dos aspectos errôneos da interpretação do mundo da experiência, assim refere:

A causa principal dos nossos erros deve encontrar-se nos preconceitos da nossa infância. 
E aqui podemos observar a primeira e principal causa dos nossos erros. Durante os primeiros anos de vida, o espírito encontrava-se tão estreitamente ligado ao corpo que não se aplicava a nada além dos pensamentos pelos quais os objetos causavam impressões ao corpo; tampouco referia esses pensamentos a algo existente além de si, mas, simplesmente, sentia a dor quando o corpo era ferido, ou prazer, quando o corpo recebia algo benéfico, ou, se o corpo fosse afetado de maneira que não fosse nem beneficiado nem ferido, o espírito experimentava as sensações que denominamos gosto, cheiro, som, calor, frio, luz, cor e outras semelhantes, que em verdade não representam nada existente fora do nosso pensamento, e variam de acordo com as diversidades das partes e modos como o corpo é afetado. O espírito ao mesmo tempo também percebia magnitudes, figuras, movimento e coisas afins, que não se lhe apresentavam como sensações, mas como coisas ou modos de coisas existentes, ou capazes de existir fora do pensamento, embora ainda não notasse essa diferença entre os dois tipos de percepção. E depois, quando a máquina do corpo - que foi fabricada pela natureza de modo que pudesse, por sua própria força inerente, mover-se em vários sentidos - voltando-se ao acaso para todos os lados, seguia o que era útil e evitava o que era prejudicial, o espírito, que era estreitamente conectado a ele, refletindo sobre os objetos que ele perseguia ou evitava, observou, primeiramente, que existiam fora de si, e não apenas lhes atribuía magnitudes, figuras, movimentos, e outras coisas afins, que apreendia ou como coisas ou como modo das coisas, mas, além disso, atribuía-lhes gostos, odores e as outras idéias dessa sorte, cujas sensações eram causadas por ele mesmo; e como só considerava outros objetos na medida em que eram úteis ao corpo em que estava imerso, julgava que havia mais ou menos realidade em cada objeto conforme as impressões que causavam ao corpo e lhe parecessem mais ou menos fortes. Daí emergiu a crença de que havia mais substância ou corpo nas pedras e nos metais do que no ar ou na água, porque o espírito percebia neles mais dureza e peso. Além disso, pensava que o ar era meramente nada, uma vez que não experimentávamos agitação dele no espírito, ou não o sentíamos nem quente nem frio. E como as estrelas não o faziam sentir mais luz do que a chama de uma tocha, supúnhamos que cada estrela não era maior do que a chama de uma tocha. Novamente, como o espírito ainda não observava que a Terra girava em torno do seu eixo, e que a sua superfície era curva como a de um globo, estava por isso mais disposto a julgar que a terra era imóvel e que a sua superfície era plana. E nosso espírito foi imbuído desde nossa infância de mil outros preconceitos do mesmo tipo que depois em nossa juventude esquecemos que os aceitamos sem suficiente exame, e os admitimos como dotados da mais alta verdade e clareza, como se os tivéssemos conhecido por meio dos sentidos, ou que foram implantados em nós pela natureza.

O texto acima, da lavra de Descartes, enquadra-se perfeitamente ao percebido hoje nas Neurociências, pois, o que Descartes chama de "preconceitos de nossa infância", a Neurociência explica através dos conceitos de "períodos críticos" do entendimento do mundo, presentes no alvorecer da vida de cada um. O filósofo continua explicando as causas primaciais do "erro" no interpretar-se o mundo, através dos seguintes textos, às páginas seguintes do mesmo livro citado acima (55/57): 
A segunda causa de nossos erros é que não conseguimos esquecer esses preconceitos.

E embora agora, em nossos anos de maturidade, em que o espírito, não sendo mais plenamente sujeito ao corpo, não tem o hábito de referir todas as coisas a ele, mas também busca descobrir a verdade das coisas consideradas em si mesmas, observamos a falsidade de um grande número de juízos que formamos antes; contudo, experimentamos uma dificuldade de expugná-los de nossa memória, e, na medida em que permanecem lá, dão origem a vários erros. Assim, por exemplo, desde nossos primeiros anos imaginamos que as estrelas são extremamente pequenas, temos grande dificuldade em nos livrarmos dessa imaginação, embora seja assegurado por razões astronômicas evidentes que são enormes tão predominante é o poder da opinião preconcebida.

A terceira causa é que nos fatigamos quando prestamos atenção aos objetos que não estão presentes aos sentidos; e estamos, assim, acostumados a julgá-los não a partir da percepção presente, mas a partir da opinião preconcebida.

Além disso, nosso espírito não pode considerar nenhum objeto sem experimentar com o tempo alguma dor e fadiga; e, de todos os objetos, tem maior dificuldade em observar aqueles que não estão presentes nem aos sentidos nem à imaginação: seja porque lhe é natural por sua união com o corpo, ou porque em nossos primeiros anos, ocupado meramente com percepções e imaginações, tornou-se mais familiar a elas, e adquiriu mais facilidade em pensar nesses modos do que em qualquer outro. Por conseguinte, ocorre também que muitas pessoas são incapazes de conceber qualquer substância, exceto o que é imaginável e corpóreo e até mesmo sensível, pois ignoram a circunstância de que somente os objetos que possuem extensão, movimento e figura são imagináveis; ao passo que há muitas outras coisas que são inteligíveis; e persuadem-se de que nada pode subsistir, senão o corpo, e, enfim, que não há corpo que não seja sensível. E uma vez que, em verdade, não percebemos nenhum objeto tal como é apenas pelos sentidos, (mas apenas a nossa razão exercida sobre os objetos sensíveis), como daqui em diante se demonstrará com clareza, sucede que a maioria das pessoas só percebe as coisas confusamente.

A quarta fonte de nossos erros é que ligamos os nossos pensamentos a palavras que não os exprimem com exatidão.

Finalmente, uma vez que para o uso do discurso ligamos as nossas concepções a determinadas palavras pelas quais as exprimimos, e confiamos à memória nossos pensamentos em conexão com esses termos, e como em seguida consideramos mais fácil lembrar das palavras do que das coisas por elas significadas, dificilmente conseguimos conceber algo com tal distinção a ponto de separar inteiramente o que concebemos das palavras selecionadas para expressá-lo. Por isso, a maioria dos homens presta mais atenção às palavras do que às coisas; e, por conseguinte, freqüentemente aceitam termos aos quais não vinculam nenhum significado, ou porque pensam que uma vez os compreenderam, ou porque imaginam que os receberam de outros que os compreenderam corretamente. Este não é, contudo o lugar para tratar desse assunto em detalhes, visto que a natureza do corpo humano ainda não foi exposta, tampouco o foi a existência do corpo como estabelecido; apesar de tudo, parece-me que aquilo que disse é suficiente para ajudar a 
distinguir as nossas concepções claras e distintas daquelas que são obscuras e confusas.

Estudando-se os textos acima produzidos por Descartes, pode-se por analogia, em se observando documentos médico-legais, documentos estes do cotidiano pericial, ou ainda, lendo-se prontuários de serviços de prontos socorros e prontos atendimentos médicos no país, encontrar-se com acentuada freqüência os referidos "preconceitos da infância" descritos e comentados pelo filósofo. Veja-se, por exemplo, a enorme quantidade de ferimentos ou feridas ditas "corto - contusas" descritas nos aludidos documentos. Ora, nos cursos de Medicina Legal, ao se tratar dos agentes vulnerantes é estabelecido o nexo causal entre a ação instrumental e a lesão conseqüente. A lesão corto-contusa só pode ser produzida por ação vulnerante corto - contundente, é obvio e repetitivo falar-se. No entanto, é comum atrelar-se o epíteto de corto - contusa a qualquer ação instrumental desde que a solução de continuidade da pele esteja presente. Como se explicaria tal situação à luz dos ensinamentos cartesianos? $\mathrm{O}$ ser humano em nosso país, na sua infância, com freqüência se acidenta e sofre soluções de continuidade da pele, nestas situações é dada a estas lesões a denominação popular de "corte", denominação esta que perdura em sua memória e ali se consolida. Ao estudar uma classificação científica da relação agente/lesão, ele não esquece os "preconceitos da infância" e embora saiba a devida classificação, na azáfama do cotidiano nos serviços de urgência e emergência, usa palavras inadequadas ao proceder científico e retorna aos referidos preconceitos. Ao ser instado sobre este procedimento alguns destes profissionais, reagem com indiferença, pois no entendimento deles isto não tem relevância. Pois, qual o problema de relacionar-se indevidamente e semanticamente a díade agente/lesão se o paciente foi devidamente tratado. Descartes ainda aborda, nos textos acima referenciados, a questão da "fadiga" no pensar e refletir sobre coisas que não estão presentes aos sentidos. Na situação acima referida sobre a lesão corto-contusa, instala-se outro problema, o termo "lesão" é do senso comum, presente no imaginário das pessoas, nas mais diversas formas, já o termo “corto-contusa", é da linguagem pericial e, portanto, técnica, remete à ação instrumental e ao nexo de causalidade ali presente, não é, assim, linguagem comum. O que ocorre naquelas situações onde se praticam diversos atos seqüenciais, portanto, em situação de azáfama é o automatismo próprio de circuitos neurais estabelecidos, por exemplo, nos "períodos críticos", e que não foram modificados mesmo na "experiência", onde o profissional prescreve medicamentos, relata eventos, executa procedimentos, reagindo de forma imediata (ou seja, sem mediação), aos reclamos de cada situação. 
Descartes (2007: 25/26) ao tratar dos "princípios do conhecimento humano", deixa evidente os elementos gerais que devem orientar o "ser humano" nesta aquisição, que sejam de tal forma que se possam minimizar as possibilidades de "erro", especialmente quando se pensa ciência e que são os seguintes:

Para examinar a verdade, é necessário, ao menos uma vez no curso de nossa vida, duvidar, o mais possivel, de todas as coisas.

Como uma vez fomos crianças, e como formamos diversos juízos quanto aos objetos apresentados aos nossos sentidos quando ainda não tínhamos completo uso de nossa razão, há vários preconceitos que nos impedem agora de alcançar o conhecimento da verdade; e parece impossível para nós libertar-nos deles, a menos que tomemos a iniciativa de duvidar, pelo menos uma vez na vida, de todas as coisas em que pudermos descobrir a mínima suspeita de incerteza.

Há, também, que considerar como falso tudo que é duvidoso

Além disso, será igualmente útil rejeitarmos como falsas as coisas de que formos capazes de duvidar, de modo que possamos com maior clareza descobrir aquilo que possui maior certeza e é mais fácil de conhecer.

Por que podemos duvidar das coisas sensiveis?

Por conseguinte, uma vez que agora temos o desígnio apenas de nos ocuparmos da investigação da verdade, duvidaremos, em primeiro lugar, se, de todas as coisas que caíram sob a alçada dos nossos sentidos, ou que, alguma vez imaginamos, alguma realmente existe, primeiramente, porque pela experiência sabemos que os sentidos por vezes erram, e seria imprudente confiar muito naquilo que já nos enganou, mesmo que só uma vez; em segundo lugar, porque nos sonhos perpetuamente nos parece que percebemos ou imaginamos uma infinidade de objetos que não têm existência. E para aquele que se resolve assim por uma dúvida geral, já não aparecem sinais que lhe faça distinguir com certeza o sonho do estado de vigília.

Por que podemos duvidar também das demonstrações matemáticas?

Também duvidamos de todas as outras coisas que outrora já nos pareceram muito certas, mesmo das demonstrações matemáticas e dos seus princípios, que até o presente consideramos auto-evidentes; em primeiro lugar, porque por vezes vimos homens se equivocarem em tais matérias, e admitirem como absolutamente certas e auto-evidentes o que a nós parecia falso...

Naquelas situações acima referidas, nas quais Descartes explica os erros de nosso entendimento, oriundos, hoje sabemos, dos caminhos neurais dos denominados "períodos críticos" que prevalecem sobre aqueles advindos do aprendizado posterior, ou seja, por exemplo da tentativa do pensar científico, o que, necessita evidentemente de correção, em nome da boa prática da ciência, inclusive da ciência médico-legal. A correção destes desvios é possível por uma leitura adequada da experiência? Por uma atitude reflexiva, que permita 
viagens do exterior ao interior do entendimento e vice-versa? Por leituras da experiência repetidas que permitam mudanças no entendimento e melhor consecução de idéias claras e distintas?

Ao usar-se o cogitatio cartesiano, ou seja, o pensar do filósofo francês, enquanto capacidade do encéfalo humano de entender (no sentido kantiano do termo) tudo e toda coisa que percebido e apercebido por nós, nos seja consciente, porém, não só o entender, mas como refere Descartes, também o "imaginar", o "sentir", e por consequiência a percepção e a apercepção do fenômeno, ou seja, uma "leitura da experiência" está diante dos caminhos neurais que possibilitam a leitura do "mundo", na ambiência científica.

O pensar "algo", ou, melhor ainda, no campo das ciências biológicas, o pensar o "fenômeno" como elemento primevo da atividade científica, da tomada de consciência do mesmo, ou seja, a "apercepção fenomênica" está consubstanciada naquilo que Kant chama de "unidade originariamente sintética da apercepção". Perceba-se o que relata o filósofo, (Kant 1994: 131-132):

O eu penso deve poder acompanhar todas as minhas representações; se assim não fosse, algo se representaria em mim, que não poderia, de modo algum, ser pensado, que o mesmo é dizer que a representação ou seria impossível ou pelo menos nada seria em mim. A representação que pode ser dada antes de qualquer pensamento chama-se intuição. Portanto, todo o diverso da intuição possui uma relação necessária ao eu penso, no mesmo sujeito em que esse diverso se encontra. Esta representação, porém, é um ato da espontaneidade, isto é, não pode considerar-se pertencente à sensibilidade. Dou-lhe o nome de apercepção pura, para a distingüir da empírica ou ainda o de apercepção originária, porque é aquela autoconsciência que, ao produzir a representação eu penso que tem poder de acompanhar todas as outras, e que é uma e idêntica em toda a consciência, não pode ser acompanhada por nenhuma outra.

O ato pericial em si, mesmo na visão aristotélica do em si (cuide-se aqui de evitar uma interpretação unicamente metafísica), deve ser realizado e estabelecido, por atitude perscrutadora e ao mesmo tempo reflexiva do perito, exige uma tomada de consciência no sentido piagetiano do termo e também ser fundamentado nos pressupostos cartesianos citados acima e ainda nos conceitos de percepção e apercepção kantianos, quando o intuito é fazerse ciência, reportar-se ciência, atendendo-se ao repto clássico da Medicina Legal, ou seja, o visum et repertum. $\mathrm{O}$ uso da Leitura da Experiência fundado no pensar piagetiano, mostrará caminhos a serem percorridos pelos peritos, pois esta leitura da experiência é derivada das 
longas reflexões e estudos dos filósofos citados acima, especialmente Descartes e Kant, feitas por Piaget e referenciadas nos textos seguintes.

Consideremos também, algumas noções importantes, codificadas especialmente pela Filosofia da Ciência onde a busca do "universal" e do "necessário" é permanente e a "contingência" é negada como fundamento científico, especialmente nos "axiomas" matemáticos, nos "princípios" da Física que durante todo o tempo foram os únicos referenciais do fazer-se ciência, e que já apareciam nos autores acima referenciados.

Considerem-se ainda situações tais como: concordância entre discurso e realidade, entre a idéia que forma o espírito e o fato real, demonstração da verdade ou veracidade, anelo pela fundamentação lógica da prova e até mais especificamente, a lógica das provas perante os tribunais. Além disso, a discussão entre probabilidade, certeza e verossimilhança, a questão da linguagem quando aborda a relação entre discurso e conceituação. Considere-se também o referido por Descartes em texto acima, onde o filósofo prescreve as seguintes regras ao se buscar a "verdade": para examinar a verdade, é necessário, ao menos uma vez no curso de nossa vida, duvidar, o mais possível, de todas as coisas. Há também que considerar como falso tudo que é duvidoso. Porque podemos duvidar das coisas sensiveis? Porque podemos duvidar também das demonstrações matemáticas? Tais assertivas e questões, especialmente a possibilidade de duvidar-se até das demonstrações matemáticas, estão bem consubstanciadas em texto do filósofo e matemático Bell (1945: 49), em trecho do seu livro "The Developement of Mathematics", onde assevera a absoluta necessidade de se ter conceitos unificadores, que organizariam os inúmeros dados científicos presentes nas ciências atuais:

\footnotetext{
A mind which rests content which a collection of facts is no scientific mind. The formulas in a mathematical hand book are no more mathematics than are the words in a dictionary a literary masterpiece. Until some unifying principle is conceived by which an amorphous mass of details can be given structure, neither science non mathematics has begun.

(Tradução livre: A mente que descansa tranqüila com uma coleção de fatos é uma mente não científica. As formulas nos livros de matemática não são mais matemática do que são as palavras no dicionário de obras literárias. Até que alguma unificação de princípios é concebida para que uma amorfa massa de detalhes possa ser estruturada nenhuma ciência nem matemática tiveram início).
}

Diante do cenário amplo e complexo em que se encontra a Medicina Legal, onde os diversos liames com as outras ciências é uma realidade inconteste, a reflexão de Bell, citada 
anteriormente, apresenta grande assertividade. Quando se analisam documentos médico-legais (como será constatado na pesquisa empírica desse trabalho), que se apresentam ora como uma "coleção de fatos", ora como um "amontoado de dados" fica então simplificada a tarefa de se demonstrar a necessidade de conceitos capazes de determinar os elementos demarcatórios da fronteira entre a atividade científica, a ciência aplicada e a teoria científica, no universo da Medicina Legal. Torna-se explicitamente necessária uma "Leitura da Experiência", adequada como instrumento, que auxiliará o entendimento do operador da Medicina Legal no interpretar e no tornar distintos os diversos fenômenos do seu cotidiano propiciando então, uma prática fundamentada no mais estrito caminho da ciência.

Esta Tese terá então, também o objetivo de aprofundar a Leitura da Experiência na Medicina Legal com fundamentação científica, tendo como referência a Filosofia da Ciência. Embora essa leitura tenha estado sempre presente, na longa existência da Medicina Legal, ela ainda é, muitas vezes, imperfeita, pois embora as diversas ligações com outras ciências ampliem sobremaneira seu universo, tal situação tem levado a generalizações conceituais que impossibilitam determinar uma prática científica consistente dela derivada.

As reflexões dos filósofos da ciência trouxeram muitas luzes à questão da observação científica ao distingui-la da "observação ingênua" e conceituá-la como "Leitura da Experiência", tal leitura, no universo da Medicina Legal, refere-se aos fatos e à relação entre eles. Piaget, (1958), à página 93, diz que a leitura da experiência não é uma simples leitura, mas consiste em introduzir na experiência a ser lida uma esquematização que permite leituras cada vez mais precisas, organizadas em função da prova, bem na direção do que propõe Bell.

A retomada do universo kantiano se faz presente ao discutir-se a "Leitura da Experiência", leitura esta fundada nos processos cerebrais, ou seja, no âmbito do que Kant definiu como apriori, pois, com certeza, conhecia a filosofia cartesiana e sua abordagem do mesmo tema é feita não pela ótica racionalista, mas sim através do idealismo transcendental.

A tomada de consciência do universo fenomênico do pensar kantiano fundamentado numa Filosofia da Ciência, filosofia esta, iniciada pelo filósofo de Königsberg e universo este citado acima, traria luz a esta "Leitura da Experiência"? Em nosso entendimento, assim, o pensamos. É possível através do estudo e das possibilidades que a "Razão" (no sentido kantiano do termo) propicia atingir-se este desiderato. 
A transição do universo kantiano quando este trata da experiência, onde os fenômenos estão considerados como expressão elementar da consciência e visualizados enquanto expressões da física newtoniana para o complexo e multifatorial universo da Biologia é feita por Piaget, que partindo de Kant criou uma teoria do conhecimento baseada nos fundamentos da ciência biológica. Zélia Ramozzi-Chiarottino (1994: 29/30) assim demonstra o denominado "kantismo evolutivo" de Jean Piaget:

Entendemos a obra de Piaget como uma retomada da problemática kantiana
que se resolverá à luz da Biologia e da concepção do ser humano como um
animal simbólico. Reencontramos aí, de um lado, as preocupações de Kant e,
de outro, aquelas de Cassirer, o mais ilustre dos neokantianos. Num dos seus
artigos autobiográficos, diz Piaget: "Nesta época (a de estudante), faço três
descobertas que modificam meu biologismo ingênuo. A primeira, sozinho;
as duas outras, sob a influência de meu mestre de Filosofia, o lógico Arnold
Reymon, e do progresso de minhas leituras de Zoologia. A primeira é a de
que, se partirmos, como Le Dantec, da dualidade das funções, que ele chama
assimilação e imitação (eu digo hoje assimilação e acomodação), o
conhecimento não é simplesmente imitação dos objetos, como acreditava Le
Dantec no seu empirismo, mas sim assimilação às estruturas do sujeito e do
organismo. Era passar docemente de Le Dantec a um kantismo evolutivo..."
Ora, é este "kantismo evolutivo" que vamos analisar. Apesar desta e de
outras colocações autobiográficas, Piaget tem sido classificado por muitos
como "positivista", provavelmente por ter vinculado o problema do
conhecimento à observação dos fatos e ao mesmo tempo à epistemologia.
Entretanto, como ele mesmo disse repetidas vezes, nada há em seu sistema
de "positivismo" a não ser o ocupar-se de fatos positivos que não obstante,
refutam o Positivismo enquanto forma de epistemologia que ignora ou
substitui a atividade do sujeito em benefício apenas da constatação ou da
generalização de leis constatadas. Ora, diz ele que tudo que encontra lhe
mostra o papel da atividade do sujeito e a necessidade racional da explicação
causal. "Eu me sinto muito mais próximo de Kant ou de Brunschvig que de
Comte".

Para que se chegue à "leitura da experiência" que conduz à prova no âmbito da Medicina Legal, ter-se-á que discutir o problema da fronteira entre a constatação (constituída de juízos sintéticos) e a inferência (o dado a priori proveniente do funcionamento cerebral). Mas existiria uma constatação pura ou ela seria sempre produto de uma elaboração? Diz Piaget (1958: 103): (...) "Il est impossible de percevoir deux objets sans les mettre, perceptivement déjà, en relation l'un avec l'autre: or, la mise en relation est une action logicomathématique” (...) Tradução livre: "é impossível perceber-se dois objetos sem colocá-los, já perceptivamente, em relação um com o outro: ora, o estabelecimento de relação é uma ação lógico-matemática". A ação lógico-matemática é aquela na qual o sujeito do conhecimento introduz propriedades nos objetos; por exemplo, igual, diferente, maior que, menor que, 
todos, alguns, nenhum, etc. propriedades bem diferentes daquelas físicas, por exemplo: cor, forma e tamanho, temperatura, densidade, consistência, etc. $\mathrm{O}$ autor ainda comenta à mesma página que as relações perceptivas são essencialmente deformantes no sentido de que dão lugar a erros sistemáticos ou a "ilusões" de todos os tipos.

O que a Lógica Clássica e a filosofia kantiana fornecem à teoria piagetiana (Epistemologia Genética ou Gênese do Conhecimento Científico) e, nós entendemos, também à Medicina Legal, é uma nova luz sobre a estrutura das operações possíveis à inteligência humana, portanto, às coordenações entre fatos reais. A leitura da experiência depende de ambas as coisas.

Sabemos desde o início, que a assimilação mental e, portanto, a constatação, comporta mecanismos inferenciais, centro do processo cognitivo. Portanto, sendo a inferência é o elemento a priori da constatação a mais elementar, está sempre presente em qualquer tipo de conhecimento.

O conhecimento se inicia na experiência, como o definiu Aristóteles, na sua Metafísica, "mas dela não deriva," observou Kant na Crítica da Razão Pura, justamente porque o conhecimento resultaria, segundo o grande filósofo, do encontro da Razão (Vernunft) com a experiência, por intermédio do Entendimento (Verstand).

Então, hoje em dia, perguntaríamos: como se inicia o conhecimento e a interpretação do mundo? Como este mesmo conhecer evoluiria? O conhecer pode ser consolidado? Estas questões são respondidas através da teoria do conhecimento científico (ou seja, aquilo que desde Aristóteles chamamos episteme) elaborada pelo biólogo e filósofo Jean Piaget. Diz ele (1970/1990: 7- 8):

De um lado, o conhecimento não procede, em suas origens, nem de um sujeito consciente de si mesmo nem de objetos já por ele identificados, resultaria de interações que se produzem entre o sujeito e o objeto e que dependem, portanto, dos dois ao mesmo tempo.

Com isso, Piaget quer dizer que o conhecimento depende, simultaneamente, de um lado, do sujeito com suas estruturas mentais específicas para o ato de conhecer (e cujo funcionamento paradigmático é o classificar e ordenar que conduzem à Lógica de classes e relações e que, seria a chamada experiência matemática), de outro lado, dos fatos empíricos, 
objeto do conhecimento desse sujeito, graças a ações estruturantes do real e que ele chamou de "experiência física", realizada inicialmente por intermédio de seus "esquemas" de ação adquiridos nas trocas do organismo com o meio e posteriormente pelas possibilidades de estabelecer relações abstratas ofertadas pelo funcionamento cerebral também na constante "troca" com o meio físico e social.

Piaget comenta que enquanto Kant distinguia as duas dicotomias do apriori/ aposteriori e do analítico/sintético segundo as diversas combinações que conhecemos, o empirismo lógico contemporâneo pretende caracterizar a dualidade dos conhecimentos logico-matemáticos e dos conhecimentos físicos (ou experimentais em geral) por intermédio de uma única dicotomia, analítico e sintético; o analítico confundindo-se com dedutivo puro, logico-matemático, e o sintético definindo-se pelo recurso à constatação. Mas seria possível à inteligência humana dividir-se em dois aspectos inteiramente assim dissociáveis: um constituído por formas ou estruturas lógicas que tenderiam à linguagem e o outro por conteúdos que tenderiam à experiência perceptiva como já observara Piaget? O problema da natureza dos juízos analíticos e sintéticos está na base da questão da leitura da experiência, porque é o elo entre aquilo que o sujeito do conhecimento coloca de sua inteligência endógena (logo orgânica), e cujo "sintoma" é exógeno (e se revela na sua possibilidade de estabelecer relações), na sua capacidade de "ler" e interpretar os fatos. É então, essencial na questão da inferência e da constatação que definem o problema da leitura da experiência. O problema é então aquele de dissociar a inferência da constatação, em função da natureza dos juízos que o leitor da experiência usa. Esse problema é de considerável dificuldade psicológica porque existem muitos degraus no processo inferencial e porque é muito difícil (senão impossível) alcançar um estado que seria caracterizado pela constatação pura na qual o intérprete da experiência usaria apenas juízos sintéticos, como pensa a maioria, no afã de descartar o juízo sintético a priori.

Ora, tanto em Piaget, quanto em Kant, as dicotomias citadas acima seriam subsumidas nos "esquemas" e estruturas mentais piagetianos e no "esquematismo dos conceitos puros do entendimento" kantianos. Para Kant (1994: 181) a esquemática do entendimento puro não é outra coisa que o conjunto de condições "puras", ou seja, independente da experiência, que seria originada na sensibilidade "pura", pela subordinação necessária desta ao entendimento no íntimo da unidade de uma mesma consciência seria necessário, igualmente, uma 
homogeneidade entre o conteúdo do objeto e a representação do conceito. Veja-se o que nos diz o filósofo sobre o acima referido:

Em todas as subsunções de um objeto num conceito, a representação do primeiro tem de ser homogênea à representação do segundo, isto é, o conceito tem de incluir aquilo que se representa no objeto a subsumir nele; é o que precisamente significa esta expressão: que um objeto esteja contido num conceito. Assim, possui homogeneidade com o conceito geométrico puro de um círculo, o conceito empírico de um prato, na medida em que o redondo, que no primeiro é pensado, se pode intuir neste último.

A partir do texto kantiano acima aludido onde a homogeneidade é conditio sine qua non da díade objeto/conceito, como fica a díade seguinte, ou seja, os conceitos puros do entendimento de um lado e as intuições empíricas de outro lado? Como seria possível a inclusão destas intuições sob tais conceitos e por conseqüência a aplicação das categorias aos fenômenos? O fenômeno em Kant e aludido acima, é "a unidade mais elementar da consciência"; a observação fenomênica é feita de forma consistente na "leitura da experiência" piagetiana, posto que apesar dos questionamentos acima referidos, tal inclusão é aí efetivada, torna-se então evidente a necessidade de um "tertium" que seja homogêneo à categoria por um lado, quanto ao fenômeno por outro lado e assim possibilite a aplicação da primeira ao segundo. Este tertium, ou elemento intermediário deve ter origem na ratio, ou seja, deve ser intelectual por um lado e sensível por outro. Esta construção é o que Kant chama de "esquema transcendental". Uma dúvida, no entanto se apresenta ao se fazerem estas incursões no pensar kantiano: em nossa experiência psicológica se encontra um elemento de união que estabeleça as propriedades, ou seja, qualifique este "esquema"? Para Kant (1994: 181-182) a resposta é positiva e o elemento de união que estabelece as referidas propriedades é o "tempo", como condição íntima de nossa consciência, portanto, inerente à mesma, que une simultaneamente o entendimento e a sensibilidade. Vejam-se as palavras de Kant abaixo referenciadas:

Ora, os conceitos puros do entendimento, comparados com as intuições empíricas (até mesmo com as intuições sensíveis em geral), são completamente heterogêneos e nunca se podem encontrar em qualquer intuição. Como será, pois, possível a subsunção das intuições nos conceitos, portanto a aplicação das categorias aos fenômenos, se ninguém poderá dizer que esta, por exemplo, a causalidade, possa também ser intuída através dos sentidos e esteja contida no fenômeno? Esta interrogação tão natural e importante é verdadeiramente o motivo porque se torna necessário uma doutrina transcendental da faculdade de julgar para mostrar a possibilidade de aplicar aos fenômenos em geral os conceitos puros do entendimento. Em 
todas as outras ciências, em que os conceitos pelos quais o objeto é pensado em geral, não são tão diferentes e heterogêneos, relativamente àqueles que representam esse objeto em concreto, tal como é dado, é desnecessário dar uma explicação particular à aplicação dos primeiros ao último.... $\mathrm{O}$ conceito do entendimento contém a unidade sintética pura do diverso em geral. $\mathrm{O}$ tempo, como condição formal do diverso do sentido interno, e, portanto, da ligação de todas as representações, contém um diverso a priori na intuição pura. Ora, uma determinação transcendental do tempo é homogênea à categoria (que constitui a sua unidade) na medida em que é universal e assenta sobre uma regra a priori. É, por outro lado, homogênea ao fenômeno, na medida em que o tempo está contido em toda representação empírica do diverso.

O estudo, as análises, as reflexões dos comentadores, epistemólogos, filósofos, cientistas etc. têm isto em comum, ou seja, um pensar especial, e que, ao contrário disso, para o adulto não-lógico de profissão, isto é, não educado a pensar sobre as normas que regem o pensamento (comum ou formalizado), o único critério de verificação é o de procurar, como dizem muitos dos sujeitos adultos de pesquisa de nossos Laboratórios, aquilo que é "conforme a realidade". Contudo, todos esses sujeitos são capazes de raciocínio formal, ou hipotéticodedutivo, mas coisa diferente é usar tal modo de raciocinar e outra é refletir, pensar, sobre seu mecanismo ou suas condições, dito de outra maneira, fazer em graus diversos, uma teoria ou uma codificação normativa, como bem observou Piaget em toda sua obra. Deste ponto de vista, da reflexão sobre a prova por inferência pura (ou do erro por vício da forma independentemente do conteúdo) nenhum dos nossos sujeitos, chega a distinguir o "logicamente falso" do "empiricamente falso". Houve confusão entre "provar logicamente" e outra realidade: "de acordo com os fatos". As afirmações consideradas erradas foram sempre aquelas onde houve um erro de constatação. Isso acontece porque na ausência da tomada de consciência dos mecanismos inferenciais, o adulto médio acredita que todo erro de raciocínio se traduz por um erro de fato e que é suficiente, então, examinar o acordo da conclusão com os fatos para saber se a dedução está correta ou não. No espírito do intérprete dos textos não habituado ao ponto de vista genético, quer dizer, à idéia de uma estruturação progressiva do objeto em função das ações do sujeito, portanto, das construções cada vez mais complexas das estruturas mentais, logo, da capacidade de raciocinar e habituado ao contrário com o ponto de vista "realista ingênuo" segundo o qual os objetos são aquilo que são para todo observador adulto e cientificamente bem informado, esse fato parecerá natural. 
Buscando-se em Kant os "princípios do entendimento puro", sumamente já estabelecidos nas "categorias", ou ainda, no que o filósofo denomina de "princípio analítico e princípio sintético", referidos acima; visualizando-se o referido por Piaget em sua "leitura da experiência”, deve-se dar razão a Kant quando diz que o conhecimento objetivo se faz por intermédio dos conceitos nos juízos sintéticos a priori. O entendimento e a criação piagetiana da "leitura da experiência" derivam em diversas situações do estabelecido por Kant. Veja-se, por exemplo, que na acepção do filósofo o juízo sintético a priori é definitivamente a consciência imediata (sem mediação) que se toma do "objeto", na síntese aperceptiva dos fenômenos. Ora, o objeto e o fenômeno são o fulcro da leitura piagetiana da experiência, portanto, este juízo sintético puro ou primevo, assume, se apropria, da função de constituir, de permear objetos aos nossos pensamentos. Aprofundando-se a incursão no universo kantiano do "entendimento", pode-se dizer que a síntese aperceptiva, ou seja, a modulação da apercepção, realizada no córtice associativo temporal apresenta o evoluir complexo das condições formais, ou seja, independentemente dos conteúdos, suscetíveis de análises cada vez mais complexas. Tal situação foi muito bem estabelecida por Piaget (1958) capítulo IV do livro La Lecture de L'Expérience, quando este diz:

Le but de cette étude était triple, (1) Il s'agissait d'abord de montrer que la logique ne constitue pas une forme imposée après coup à un contenu préalable, mais qu'il existe à tous les niveaux certaines structurations, autrement dit des constructions de formes, même si celles-ci demeurent peu différenciées de leurs contenus; par leur complexité croissante ces formes aboutissent alors d'étapes en étapes à ce genre particulier de structures qu'on appelle logiques, mais sans discontinuité radicale entre ces derniéres et les formes élémentaires qui les préparent. (2) Pour justifier cette manière de voir, il s'agirait ensuite de vérifier qu'il n'existe pas de «contenu préalable », autrement dit que la « lecture » de l'expérience n'est pas une simple lecture, mais consiste à introduire, dans l'expérience à lire,une schématisation permettant cette lecture.C'est cette schématisation nécessaire des structures prélogiques puis logiques, dans la mesure où celui-ci en vient à éprouver le besoin des lectures de plus en plus précises, jusqu'à celles qui sont organisées en fonction de la preuve. Or cette schématisation est déjà assurée à tous les niveaux (mais naturellement avec une rigueur d'autant moindre qu'on se rapproche de l'élémentaire) par l'activité assimilatrice du sujet: celle-ci consiste, en effet, à intégrer le donné - donc sans aperception d'un donné préalable, à des schèmes antérieurs, ou en voie de différenciation, qui seuls permettent d'attribuer á ce donné le statut d'objet de connaissance, (3) I1 s'agissait réciproquement de montrer que dès le départ, cette assimilation mentale comporte des mécanismes inférentiels, dont la fonction 
est d'assurer cette incorporation, ${ }^{1}$ et qui, d'abord inductifs ou probabilistes peuvent conduire aux inférences proprement déductives qui caractérisent les structures logiques.

Tradução livre: O objetivo deste estudo foi triplo: (1) Tratou-se antes de mais nada de mostrar que a Lógica não constitui uma forma acrescentada a um conteúdo dado no início de um processo, mas que existe em todos os níveis da embriologia mental, um certo tipo de estruturação, dito de outra maneira, de construção de formas, mesmo que inicialmente permaneçam pouco diferenciadas de seus conteúdos. Por sua complexidade crescente, essas formas alcançam então de etapa em etapa esse gênero particular de estruturas que nós chamamos estruturas lógicas, mas sem descontinuidade radical entre essas últimas e as formas elementares que as preparam. (2) Para justificar esta maneira de ver, tratar-se-ia em seguida de verificar que não existe um conteúdo pré - existente, dito de outra maneira, que a leitura da experiência não é uma simples leitura, mas consiste em introduzir, na experiência a ser lida, uma esquematização que permite essa leitura. É essa esquematização necessária a qualquer tipo de leitura da experiência que nos parece constituir a função própria das estruturas pré - lógicas, depois lógicas, nas atividades do sujeito, na medida em que essas experimentam a necessidade de leituras cada vez mais precisas, até aquelas que são organizadas em função da prova. Ora, esta esquematização está já assegurada em todos os níveis da embriologia mental (mas naturalmente com menor rigor quanto mais nos aproximamos do "elementar") pela atividade assimiladora do sujeito: e esta esquematização consiste em integrar o dado - desde o momento no qual ele é dado, -logo sem apercepção de um dado anterior- a esquemas anteriores que sozinhos permitem atribuir a este dado o estatuto de objeto do conhecimento. (3) Tratava-se reciprocamente de mostrar que desde o início essa assimilação mental comporta mecanismos inferenciais cuja função é a de assegurar essa incorporação [ou assimilação do dado] e que, inicialmente indutivos ou probabilísticos podem conduzir às inferências propriamente dedutivas que caracterizam as estruturas lógicas.

Voltando-se ao périplo na ambiência científica de Kant, agora sob o olhar piagetiano da leitura da experiência, onde se pode perceber que esta "leitura" comporta complexidades crescentes, diferenciadas, que se movem ab initio por processos indutivos, ou seja, que levam das probabilidades, até as inferências dedutivas fundamentadas na Lógica; pois, na ótica kantiana se existe uma "síntese total" primeva, também se manifestam sínteses parciais e secundárias, que no lugar de "objetos totais" expressam unicamente, por abstração certas condições internas de "possibilidades" de "objetos". Estas sínteses parciais, secundárias, por sua vez, promovem outros juízos "puros" evolutivos no plano do "dado" material e ainda na apercepção fenomênica. Leve-se em consideração que na filosofia kantiana os juízos sintéticos a priori expressam as relações gerais constitutivas da experiência. Observe-se também que estas relações gerais, e toda a diversidade fenomênica estão, no universo do 
filósofo, nas "categorias" do entendimento, categorias estas que proporcionam uma real tábua de princípios e de regras do seu uso objetivo pelo Entendimento.

Ao estudar-se a dedução dos conceitos puros do entendimento, como forma de se antever a "possibilidade da experiência", Kant (1994: 129) diz:

É completamente contraditório e impossível que um conceito deva ser produzido a priori e se reporte a um objeto, embora não esteja incluído no conceito de experiência possível, nem se componha de elementos de uma experiência possível. Com efeito, não possuiria nesse caso conteúdo, pois não lhe corresponderia nenhuma intuição, visto que as intuições em geral, pelas quais nos podem ser dados os objetos, constituem o campo ou o objeto total da experiência possível. Um conceito a priori, que não se referisse a elas, seria apenas a forma lógica de um conceito, mas não o próprio conceito pelo qual algo seria pensado.

Em todos os fenômenos, o real, o objeto a ser conhecido, tem uma grandeza que pode ser estudada tanto em Kant, como em Aristóteles, ou seja, estar-se-ia diante da categoria da "qualidade", o que indicaria por antecipação certo caráter geral do conhecimento empírico. A intensidade do "real" pode ser medida, por exemplo, pela distância que separa no sentido endógeno os seus extremos: a consciência meramente formal e a síntese do dado positivo, ou seja, o grau das percepções na medida da atuação da consciência enquanto processo cerebral ou "endógeno" na linguagem piagetiana. Esta situação corresponde à representação de uma realidade possível de ser definida, pois esta realidade devidamente classificada e identificada expressa uma diversidade que lhe é própria. Em Kant, a intensidade do real pertence ao que ele denomina de "condições dinâmicas do conhecimento".

Onde estaria a fundamentação científica possível, destas condições dinâmicas do conhecimento na ótica kantiana, ou ainda, do conceito de "leitura da experiência" piagetiano? Purves (2005: 552-553) ao dissertar sobre a plasticidade no córtex cerebral adulto relata o seguinte:

Além desses estudos celulares e moleculares a respeito da plasticidade, agora também se sabe bastante a respeito da plasticidade de mapas corticais e das propriedades de campos receptivos dos neurônios corticais. Até o final da década de 1970, presumia-se que uma reorganização significativa dos circuitos corticais acontecia primariamente durante o desenvolvimento pósnatal. Essa conclusão era baseada em evidências de períodos críticos, e na relativa permanência de déficits neuronais após trauma ao SNC em adultos. Essa visão tem sido, em certo grau, modificada por evidências de que mapas topográficos no córtex somatossensorial de macacos adultos são, na verdade, capazes de uma apreciável reorganização. As quatro áreas corticais que 
definem o córtex somatossensorial dos primatas (áreas 3a 3b, 1 e 2 de Brodmann) contém, cada uma, uma representação topográfica completa da superfície corporal. Jon Kass e Michael Merzenich tiraram vantagem desse arranjo, definindo claramente a organização espacial normal de mapas topográficos nessas regiões. Eles, então, amputaram um dedo (ou cortaram um dos nervos que inervam a mão do animal) e reexaminaram os mapas topográficos daqueles animais diversas semanas mais tarde. Surpreendentemente, o córtex somatossensorial havia mudado: os neurônios corticais agora que haviam sido privados de seus sinais de entrada periféricos normais agora respondiam à estimulação de outras partes da mão do animal. Por exemplo, se o terceiro dedo era amputado, neurônios corticais que anteriormente respondiam à estimulação desse dedo respondiam agora à estimulação dos dedos 2 e 4 . Desse modo, a representação central dos dedos remanescentes havia se expandido para englobar o território cortical que havia perdido seu principal sinal de entrada. Tal "remapeamento funcional" também ocorre em núcleos sensoriais somáticos no tálamo e no tronco encefálico; na verdade, parte da reorganização dos circuitos corticais pode depender dessa plasticidade subcortical concomitante. Esse tipo de ajuste no sistema sensorial somático pode contribuir para as sensações alteradas de membros-fantasmas após amputações. Alterações plásticas semelhantes já tem sido demonstradas nos córtices visual, auditivo e motor, sugerindo que, um certo grau de plasticidade funcional seja uma propriedade geral do neocórtex maduro.

Retornando-se ao universo kantiano e piagetiano da epistemologia, porém, sob a ótica dos pressupostos das ciências tanto lógico-matemáticas, quanto biológicas, especialmente da consciência da díade tempo/espaço, referidas acima tanto em Piaget, quanto em Kant, encontrar-se-ia em nossa experiência psicológica, um elemento que permitisse ligações entre as diversas possibilidades "dinâmicas do conhecimento"?

O perito diante de um evento, diante de um fenômeno, por onde iniciaria seu périplo mental em busca da prova científica? Adentrando-se outra vez no universo kantiano, pode-se perceber que o tempo (elemento essencial no refletir do perito) ocupa decididamente situação intermédia entre a sensibilidade (aqui condição essencial ao pensar do perito) e o entendimento. Pois, por um lado, o tempo se relaciona imediatamente com o fenômeno, como parte constitutiva deste; por outro lado, o tempo, forma superior da sensibilidade, se acha ele mesmo necessariamente determinado pela unidade a priori da consciência, também da experiência psicológica, determinação esta derivada da apercepção fenomênica. Sob este aspecto o tempo adquire uma "determinação transcendental" que seria homogênea à categoria, ou seja, em cada categoria, aqui considerada como possibilidade a priori da função parcial da unidade sintética da consciência, a que corresponderia de pronto uma determinação a priori advinda da forma do tempo e que se imporia por este intermédio aos fenômenos. $\mathrm{Na}$ 
ótica kantiana, a determinação transcendental do tempo faz a função de "esquema transcendental". Por assertiva que seja esta noção de esquema transcendental, devida a acurada abstração, praticada pelo filósofo, ele mesmo demonstra que, realmente se está diante de "experiência psicológica", o que nos leva a perguntar sobre o que difere realmente "um esquema representado" (schema) da "imagem"?

Piaget (1966) ao abordar a díade conhecimento/assimilação, faz aparecer diferenças que nos permitem comparar seu pensamento com o pensar kantiano sobre a relação entre esquema representado (schema) e imagem. À página 8 ele nos diz:

(...) Dans l' hypothèse, qui sera la nôtre, d'une connaissance-assimilation, l'objet, n'est connu que conceptualisé à des degrés divers. L'image reste bien toujours le produit d' un effort de copie concrète et même similesensible de l'objet, mais, cette copie demeure fondamentalement symbolique puisque la signification effective est à chercher dans le concept.

Tradução livre: (...) Na hipótese que será a nossa, de um conhecimentoassimilação, o objeto é conhecido e conceituado em diferentes níveis. A imagem é sempre produto de um esforço de cópia concreta e mesmo símilesensivel do objeto, mas, esta cópia permanece fundamentalmente simbólica, pois a significação efetiva deve ser buscada no conceito.

E continua Piaget às páginas 453 e 455 :

(...) Dégagée la portée épistemologique de l'image, c'est alors, d'une part, établir pourquoi la connaissance ne saurait se réduire à une copie, et, d'autre part, faire la critique de l'idée même de copie en cherchant à établir qu'il ne saurait exister sans contradiction de copie exacte, car une copie n'est jamais qu'une correspondance approchée parce que relative à l'échelle considérée. (p. 453).

Tradução livre: Identificar a importância epistemológica da imagem é então, de um lado, estabelecer porque o conhecimento não poderia reduzir-se a uma cópia, e, de outro lado, fazer a crítica da própria idéia de cópia procurando mostrar que não poderia existir (sem que se admita a contradição) uma cópia exata, pois uma cópia não passa de uma correspondência aproximada na medida em que é relativa a uma escala considerada.

En bref, la notion même de copie exacte par rapport à l'objet paraît contradictoire, car, ou bien il y a copie, et elle reste globale sans atteindre l'objet sinon à l'échelle où il n' est pas dissocié en ses composantes objectives, ou bien il y a effort pour atteindre ces composantes avec exactitude, et il n'y a plus copie, mais schématisation et construction de modèles dont la vérification n'est que médiate et suppose l' union de l'expérience avec la dédution. (p. 455)

Tradução livre: Resumindo, a própria noção de cópia exata em relação ao objeto [do conhecimento] parece contraditória, pois, ou bem ela é cópia, e nesse caso é global, sem alcançar o objeto senão numa escala na qual ele não 
é dissociável em seus componentes objetivos, ou bem há um esforço para alcançar esses componentes com exatidão e, então, já não se trata de cópia, mas de esquematização e construção de modelos cuja verificação é mediata e supõe a união da experiência com a dedução.

Ao estabelecer a díade esquema/imagem, assim nos ensina Piaget às páginas acima referidas:

\begin{abstract}
Si nous appelons « schème » un instrumento de généralisation qui permet de dégager et d'utiliser les elements communs à des conduites analogues sucessives, il existe des schèmes perceptifs comme des schèmes sensorimoteurs, des schèmes opératoires, etc. ; et il existe aussi, en ce sens, des schèmes imagés en tant que permettant au sujet de construire des images analogues en des situations comparables. Mais si nous appelons "schéma" un modèle simplifié destiné à faciliter la presentation (comme un schéma topographique, etc.), il n'existe alors pas de schémas perceptifs, puisque le schéma ne sert qu'à l'évocation et à la figuration, tandis que la figuration imagée est schématisée avant tout dans le sens du schéma, bien que comportant la possibilité de schèmes.

Tradução livre: Se nós chamamos "esquema" (schème) um instrumento de generalização que permite individuar e utilizar os elementos comuns às condutas análogas sucessivas, existem, então, esquemas perceptivos enquanto esquemas sensório-motores, esquemas operatórios, etc.; e existem também nesse sentido, esquemas imagísticos que permitem ao sujeito construir imagens a eles análogas em situações análogas. Mas se nós chamamos schema um modelo simplificado destinado a facilitar a "presentação" (como um esquema topográfico, etc.), não existem então, schemas perceptivos, pois o schema é apenas utilizado na evocação e na "figuração", enquanto que a figuração imagística [imaginação] é esquematizada [pelos esquemas de ação] mas que vão em direção ao schema, ainda que comportando esquemas de ação[ou seja,os schemas envolvem esquemas de ação, porém representados, imaginados].
\end{abstract}

Para Kant, tanto a imagem quanto o esquema seriam produto da "imaginação", definida esta, como uma faculdade do "sentido interno". Portanto, a imagem de um objeto percebido é advinda de uma pluralidade fenomênica, associada não somente ao "espaço", forma do sentido externo, como ao tempo forma do sentido interno.

O perito ao trabalhar em uma situação onde se vislumbra corpo que apresenta quatro feridas pérfuro-contusas na região precordial, produzidas por projéteis de arma de fogo seqüenciais, onde se aventou a possibilidade de suicídio, advindo este de disparos de arma de fogo não automática, ou seja, um revolver de calibre 38 , nesta situação de fato, para se obter a unidade concreta de uma imagem espacial, não basta se receber a impressão bruta destes disparos e conseqüentes lesões, nem da possibilidade remota de suicídio ali referenciada; será necessário para que se entenda o evento em sua totalidade, dedicar-se atenção sucessivamente 
aos diversos fenômenos, percorrê-los; pois, a impressão espacial, recebida passivamente, justapõe indiferentemente os fenômenos isolados, sem determinar-se um agrupamento característico; há a necessidade de movimentos sucessivos de sínteses que acolhem, classificam e ordenam os fenômenos em imagens coordenadas pela inferência. Pois bem, esta última operação desenvolvida no tempo, pertence ao sentido interno e, portanto, se reduz ao que se denomina de "capacidade de imaginar".

Para Kant, o "esquema", (o schema de Piaget) pertence a esta fase de construção da imagem, é, portanto, uma determinação do sentido interno segundo o tempo. Faz-se aqui a diferenciação entre o "esquema" e a "imagem". A imagem representa o término concreto da operação imaginativa, ou seja, seu resultado. O esquema (schema) nada tem de terminado, nem de representação acabada, designa unicamente um processo segundo o qual a capacidade imaginativa constrói a imagem, o esquema é, pois um procedimento de construção imaginativa no tempo.

Dentro deste princípio de "construção imaginativa no tempo", como o médico legista pode construir os esquemas representativos que possibilitam uma imagem concreta dos eventos e fenômenos com os quais ele lida? Na ótica kantiana, as faculdades sensíveis, portas de entrada dos fenômenos em direção à consciência (veja-se aqui a conceituação neurofisiológica dos sentidos como porta de entrada da possibilidade de entendimento do mundo), se encontram passivamente impressionadas pelos dados, pelos fenômenos, recebidos segundo as condições espaciais do sujeito, portanto, na perspectiva do concreto. $\mathrm{O}$ dado, ou o fenômeno desenvolvido, deve ser nesta situação resumido e unificado pelo sentido interno, cuja forma Kant entende ser o "tempo". O tempo neste universo mede, delimita o espaço, construindo-o e reconstruindo-o sucessivamente. Se o sujeito que conhece (no dizer kantiano), por sua unidade se circunscreve à continuidade espacial medida pela continuidade temporal, o dado, o fenômeno diverso não constituiria, a cada instante, mais que um fenômeno polimorfo, passível de indefiniçõos temporais e espaciais.

Nesta condição encontrar-se-iam inúmeras dificuldades ao pensar do perito. Pois, a necessidade que permeia o seu raciocínio é a busca da "prova", numa consulta perene à consciência. A solução kantiana para isto seria a de que, o fenômeno se diversifica em unidades parciais, desenhando na diversidade do dado outros grupos mais ou menos externos e estáveis. Esta gradação espacial e temporal do dado não seria de uma diversidade 
indiferente, mas revelaria uma síntese múltipla de elementos diversos; cria aqui, Kant, um conceito que ele denominou de "representações sensíveis", ao dizer que elas delimitam e sintetizam unidades figuradas da sensibilidade. Para que isto se consolide, deve-se levar em conta que tal situação somente é possível supondo-se que o tempo na medida em que impõe sua unidade ao espaço, se acha ele mesmo unificado e contraído, por um "princípio antecedente de unificação", esta é a solução kantiana para o problema (não se trata aqui do tempo e do espaço em sua realidade ontológica, sim das funções temporal e espacial em nosso conhecimento). Neste universo, a análise psicológica confirma o raciocínio crítico, ao afirmar que a percepção sensível, ou a síntese original de uma representação, não é coisa tão simples de se imaginar. A percepção sensível supõe sempre o concurso de complicados processos inferenciais, cujo jogo mais elementar é sempre o que Kant indica: uma "ressíntese" sucessiva dos elementos espaciais dados. Ao chamar-se "imaginação construtiva" a faculdade de edificar sinteticamente uma representação sensível por meio de dado espacial, pode-se dizer que a percepção sensível exige o concurso da imaginação construtiva.

No universo kantiano, já dissemos, o conceito é a unidade mental do múltiplo, o fenômeno é a unidade elementar da consciência, (não se confunde com o "dado") a busca pela síntese conceitual é permanente e paulatina neste universo, ora, na síntese da imaginação onde, pela primeira vez, se opera o encontro de todo o conjunto das condições materiais e formais do conhecimento objetivo, o elo de união e o que Kant denomina de "esquema" (Schema). Kant (1994: 183/186) diz:

Daremos o nome de "esquema" a esta condição formal e pura da sensibilidade a que o conceito do entendimento está restringido no seu uso e, o de "esquematismo" do entendimento puro ao processo pelo qual o entendimento opera com esses esquemas. O esquema é sempre, em si mesmo, apenas um produto da imaginação; mas, como a síntese da imaginação não tem por objetivo uma intuição singular, mas tão só a unidade na determinação da sensibilidade, há que distinguir o esquema da imagem. Assim, quando disponho cinco pontos um após o outro tenho uma imagem do número cinco. Em contrapartida, quando apenas penso um número em geral, que pode ser cinco ou cem, este pensamento é antes a representação de um método para representar um conjunto, de acordo com certo conceito, por exemplo, mil, numa imagem, do que essa própria imagem, que eu, no último caso, dificilmente poderia abranger com a vista e comparar com o conceito. Ora é esta representação de um processo geral da imaginação para dar a um conceito a sua imagem que designo pelo nome de esquema desse conceito. De fato, os nossos conceitos sensíveis puros não assentam sobre imagens dos objetos, mas sobre esquemas. Ao conceito de um triângulo em geral nenhuma imagem seria jamais adequada. Com efeito, não atingiria a 
universalidade do conceito pelo qual este é válido para todos os triângulos; retângulos, de ângulos oblíquos, etc. ficando sempre apenas limitada a uma parte dessa esfera. $\mathrm{O}$ esquema do triângulo só pode existir no pensamento e significa uma regra da síntese da imaginação com vistas a figuras no espaço. Muito menos ainda um objeto da experiência ou a sua imagem alcançaria alguma vez o conceito empírico, pois este se refere sempre imediatamente ao esquema da imaginação, como uma regra da determinação da nossa intuição de acordo com um certo conceito geral. O conceito de um cão significa uma regra segundo a qual a minha imaginação pode traçar de maneira geral a figura de certo animal quadrúpede, sem ficar restringida a uma única figura particular, que a experiência me oferece ou também a qualquer imagem possível que posso representar in concreto (...). Só poderemos dizer que a imagem é um produto da faculdade empírica da imaginação produtiva e que o esquema de conceitos sensíveis (como as figuras no espaço) é um produto e, de certo modo, um monograma da imaginação pura a priori, pelo qual e segundo o qual são possíveis as imagens (...) A imagem pura de todas as quantidades (quantorum) para o sentido externo é o espaço, e a de todos os objetos dos sentidos em geral é o tempo. O esquema puro da quantidade (quantitatis), porém, como conceito do entendimento, é o número, que é uma representação que engloba a adição sucessiva da unidade à unidade (do homogêneo). Portanto, o número não é mais do que a unidade da síntese que eu opero entre o diverso de uma intuição homogênea em geral, pelo fato de eu produzir o próprio tempo na apreensão da intuição (...). O esquema da substância é a permanência do real no tempo, isto é, a representação desse real como de um substrato da determinação empírica do tempo em geral, substrato que persiste enquanto tudo o mais muda. (...) O esquema da causa e da causalidade de uma coisa em geral é o real, que, uma vez posto arbitrariamente, sempre é seguido de outra coisa. Consiste, pois, na sucessão do diverso, na medida em que está submetido a uma regra. $\mathrm{O}$ esquema da comunidade (reciprocidade), ou da causalidade recíproca das substâncias em relação aos seus acidentes, é a simultaneidade das determinações de uma com as da outra, segundo uma regra geral. O esquema da possibilidade é o acordo da síntese de representações diversas com as condições do tempo em geral (por exemplo, que os contrários não podem existir, simultaneamente, numa coisa, mas só sucessivamente), ou seja, a determinação da representação de uma coisa em tempo qualquer. O esquema da realidade é a existência num tempo determinado. O esquema da necessidade é a existência de um objeto em todo o tempo. (...) Os esquemas não são, pois, mais que determinações a priori do tempo, segundo regras; e essas determinações referem-se, pela ordem das categorias, respectivamente à série do tempo, ao conteúdo do tempo, à ordem do tempo e, por fim, ao conjunto do tempo no que toca a todos os objetos possíveis.

Para que se possa entender o universo kantiano do "esquema" no sentido geral, como o referido até então, urge adentrar-se ainda que superficialmente naquilo que o filósofo denominou de "esquemas puros", que têm a possibilidade de determinar a imaginação, como prioridade a toda intuição possível da sensibilidade. O perito médico legista que trabalha no mundo do concreto, do palpável, para que possa relatar "algo", "dado", "fenômeno", necessita ter presente em sua sensibilidade perceptiva, no seu Entendimento no sentido kantiano do 
termo, a capacidade imaginativa e o seu produto, ou seja, o "esquema" (também no sentido kantiano). Os esquemas referentes aos conceitos puros do entendimento se desenvolvem por processo geral de abstração, representados por uma "lei interna" que possibilita uma síntese sucessiva da imaginação, que depende ou pode depender de diversas influências ou experiências anteriores e das condições espaciais e gerais daquilo que Kant chamou de representação. Esta lei interna, ou seja, uma "lei sintética da imaginação" depende também de condições que já não derivam nem da diversidade do dado nem da diversidade própria da sensibilidade, aqui, entendida como "pura", ou seja, independente da experiência. Nesta situação, o esquema já não tem uma imagem temporal ou espacial, nem sequer a pureza da imagem geométrica aludida acima em relação aos triângulos, não seria mais que uma regra, que uma norma que unifica impressa no tempo, portanto, segundo as categorias do entendimento.

Buscando-se um processo, onde se possam unir as duas grandes faculdades especulativas, ou seja, o Entendimento (Verstand) enquanto faculdade constitutiva dos conceitos, e a Razão (Vernunft) enquanto faculdade geradora das idéias transcendentais, Kant coloca, interpõe uma terceira faculdade, isto é, a faculdade de utilizar os conceitos nas sentenças, uma "faculdade de predicar", na verdade a "faculdade de julgar" (Urteilskraft). No universo kantiano, a regra a priori da capacidade ou faculdade cognoscitiva, portanto objetiva, se hospeda no Entendimento; a outra regra a priori das apetições superiores (apetição no sentido leibniziano do termo, ou seja, tendência da mônada para a obtenção de novas percepções), ou seja, a ratio kantiana templo da racionalidade superior se assenta na Razão. Há lugar, pois, para colocar-se, ou, associar-se ao paralelismo das díades conhecimento/entendimento e volição/razão, faculdades intermédias, ou seja, faculdade de julgar, tertium entre a Razão e o Entendimento.

Para Kant, a faculdade de julgar é a de estabelecer o particular como compreendido sob o universal. Pode ser que, dado de antemão o universal, a faculdade de julgar se limite a subsumir (admitir uma idéia como componente de uma idéia geral) abaixo de si o particular. Neste caso o filósofo chama esta faculdade de determinante, tal é sua finalidade na aplicação das categorias aos fenômenos. Pode também ocorrer que nos seja dado unicamente o "particular", e que a posteriori nos seja cobrado, encontrar-se o "universal". Aqui, Kant diz que a faculdade de julgar é "reflexiva", porque deveria esta, conhecendo o particular como 
“objeto”, descortinar pela reflexão o universal exigido. Leia-se o que nos diz Kant (2008: 23) ao ensinar sobre a faculdade do juízo como uma faculdade legislante a priori:

A faculdade do juízo em geral é a faculdade de pensar o particular como contido no universal. No caso de este (a regra, o princípio, a lei) ser dado, a faculdade do juízo, que nele subsume o particular, é determinante (o mesmo acontece se ela, enquanto faculdade do juízo transcendental, indica a priori as condições de acordo com as quais apenas naquele universal é possível subsumir). Porém, se só o particular for dado, para o qual ela deve encontrar o universal, então a faculdade do juízo é simplesmente reflexiva.

O agir pericial, o perscrutar o fenômeno por parte do médico-legista, ocorre na ambiência do "particular", como referenciado acima e criticado e não aceito por Granger como ciência, pois não contemplaria o "universal" e o "necessário", teria o perfil do “desviante”, portanto, não seria ciência. Uma solução kantiana para este impasse seria o migrar-se de uma faculdade do juízo reflexiva, (onde, por mecanismos cerebrais indutivos transita-se do particular para o universal e se gera possibilidades), para a faculdade do juízo determinante (onde se subsume o particular no universal), ao se analisar o fenômeno. $\mathrm{O}$ fenômeno em Kant é a unidade mais elementar da consciência, deve este, de alguma forma universalizar-se, ou seja, passar do estado de impressão subjetiva na consciência para o estado de objeto em determinado momento, para tanto, deve adquirir uma propriedade, um atributo que o identifique e torne possível sua observação e estudo. No primeiro momento da observação de um fenômeno, o perito usa os atributos do mesmo, ou seja, sua característica peculiar e busca através da "faculdade do juízo reflexiva" desenvolver processos mentais, processos estes que devem ser fundamentados em conceitos que se encontram, se transformam (encontros e transformações estas, estabelecidas na dialética transcendental de Kant) e por consequiência levam à "faculdade do juízo determinante" num segundo momento. Kant (2008 ás páginas 23/24) define a faculdade de juízo determinante:

A faculdade de juízo determinante, sob leis transcendentais universais dadas pelo entendimento, somente subsume; a lei é-lhe indicada a priori e por isso não sente necessidade de pensar uma lei para si mesma, de modo a poder subordinar o particular na natureza ao universal. Só que existem tantas formas múltiplas da natureza, como se fossem outras tantas modificações dos conceitos da natureza universais e transcendentais, que serão deixadas indeterminadas por aquelas leis dadas a priori pelo entendimento puro - já que as mesmas só dizem respeito à possibilidade de uma natureza geral (como objeto dos sentidos) - que para tal multiplicidade têm que existir leis, as quais, na verdade, enquanto empíricas, podem ser contingentes, segundo a nossa "perspiciência" intelectual. Porém se merecem o nome de leis (como também é exigido pelo conceito de uma natureza), têm que ser consideradas 
necessariamente como provenientes de um princípio, ainda que desconhecido, da unidade do múltiplo.

O trânsito da "faculdade de juízo reflexiva" para a "faculdade de juízo determinante", na ambiência pericial e referida acima, comporta uma reflexão sobre o conceito de Perspiciência criado por Kant para representar a "perfeita compreensão de uma coisa, ou seja, inteiro conhecimento", originado da palavra latina Perspicientia e traduzida para o alemão pelo filósofo através da palavra Einsicht. Teria ainda, fundamento no termo latino atribuído a Cícero Perspicere, que significa "examinar com cuidado, observar atentamente, enxergar profundamente". O afirmado que remete a uma forma de juízo eminentemente prática e ao mesmo tempo racional, que deve ser acolhida com festejo na ambiência médico-legal devido à sua real significação. Ora, no agir pericial, o médico-legista deve abordar o fenômeno, seguindo os cânones estabelecidos acima para a significação do perspicere, ou seja, $a b$ initio observar com atenção, examinar detida e reflexivamente, para que seu "olhar" sobre o fenômeno seja visto com a devida profundidade e acurácia. É necessário ao agir pericial, tanto a faculdade de juízo reflexiva quanto a faculdade de juízo determinante, assim já se disse, no entanto, torna-se relevante ter-se consciência do que nos ensina Kant (2008: 24-25) a seguir:

A faculdade de juízo reflexiva, que tem a obrigação de elevar-se do particular na natureza ao universal, necessita por isso de um princípio que ela não pode retirar da experiência, por que este deve fundamentar a unidade de todos os princípios empíricos sob princípios igualmente empíricos, mas superiores e por isso fundamentar a possibilidade da subordinação sistemática dos mesmos entre si. Por isso só a faculdade de juízo reflexiva pode dar a si mesma um tal princípio como lei e não retirá-lo de outro lugar (porque então seria faculdade de juízo determinante), nem prescrevê-lo à natureza, por que a reflexão sobre as leis da natureza orienta-se em função desta, enquanto a natureza não se orienta em função das condições, segundo as quais nós pretendemos adquirir um conceito seu, completamente contingente no que lhe diz respeito. Ora, este princípio não pode ser senão este: como as leis universais têm seu fundamento em nosso entendimento, que as prescreve à natureza (ainda que somente o conceito universal dela como natureza) tenha as leis empíricas particulares, a respeito daquilo que nelas é deixado indeterminado por aquelas leis, que ser consideradas segundo uma tal unidade, como se igualmente um entendimento (ainda que não o nosso) as tivesse dado em favor da nossa faculdade de conhecimento, para tornar possível um sistema da experiência segundo leis da natureza particulares. Não como se deste modo tivéssemos que admitir efetivamente um tal entendimento (pois é somente à faculdade de juízo reflexiva que esta idéia serve de princípio, mas para refletir, não para determinar); pelo contrário, desse modo, esta faculdade dá uma lei somente a si mesma não à natureza. Ora, porque o conceito de um objeto, na medida em que ele ao mesmo tempo contém o fundamento da efetividade deste objeto, chama-se fim e o acordo de uma coisa com aquela constituição das coisas que somente 
é possível segundo fins se chama conformidade a fins (Zweckmässigkeit) da forma dessa coisa, o princípio da faculdade do juízo é então, no que respeita à forma das coisas da natureza sob leis empíricas em geral, a conformidade a fins da natureza na sua multiplicidade. $O$ que quer dizer que a natureza é representada por este conceito, como se um entendimento contivesse o fundamento da unidade do múltiplo das suas leis empíricas. A conformidade a fins da natureza é por isso um particular conceito $a$ priori, que tem a sua origem meramente na faculdade de juízo reflexiva. Na verdade não se pode acrescentar aos produtos da natureza algo como uma relação da natureza a fins neles visível, mas sim somente utilizar este conceito, para refletir sobre eles no respeitante à conexão dos fenômenos na natureza, conexão que é dada segundo leis empíricas.

Kant nos diz que a faculdade de julgar é reflexiva, pois o julgar determinante se confunde com a função sintética do entendimento. O julgar reflexivo no universo kantiano ocupa um "lócus" específico, extremamente importante, no que se refere à concepção da natureza. Diante do que nos apresenta a Natureza, com sua extrema complexidade, o que nos mostram as categorias kantianas a partir do dado empírico, é que cada elemento do fenômeno se encontra subsumido às condições gerais, por exemplo, causalidade, quantidade, qualidade, comunidade, que organizam a possibilidade de todo objeto na natureza. No julgar reflexivo kantiano, fora dos atributos gerais das categorias, apresenta-se uma multiplicidade concreta, dispersa, passível de mutações dos fenômenos sobre os quais não mais atuariam a classificação e ordenação a priori do entendimento.

Partindo dos processos cerebrais, mais especificamente dos córtices associativos, nós interpretamos que o Entendimento kantiano, por um lado, ensina quais leis gerais organizarão toda experiência, ou seja, as categorias. Por outro lado, um grande e variado universo da empiria, universo este complexo, cujas formas de agrupamentos como não se inserem em nenhum universo necessário, (como o da Física) permanecem na contingência.

Entre o universo do Entendimento e aquele das determinações (para Piaget estar-se-ia diante das constatações), citado acima, e o múltiplo complexo e mutável universo da empiria, o que Kant propõe como solução? O filósofo nos propõe que entre os princípios superiores da natureza em geral e a multiplicidade polimorfa dos fenômenos existe uma ligação, uma espécie de ponte imensa e múltipla, ou seja, o sistema de leis indutivas particulares, que sintetizam cada pormenor, cada elemento da experiência e o classifica segundo "gêneros e espécies". As denominadas leis indutivas que expressam agrupamentos empíricos de fenômenos, não proporcionam a universalidade senão em virtude de um princípio a priori. 
Poderá este princípio agrupar, formar representações mais gerais à explicação qualitativa da experiência, proporcionando um sistema que englobe gêneros e espécies? Kant nos ensina que as categorias do entendimento não podem nem de fato nem de direito atingir tal desideratum, pois, não conseguem chegar consistentemente ao fenômeno. Restringem-se às categorias, somente aos princípios apriori, ao princípio ordenador das ações, ao princípio de finalidade; impõe-se aos nossos processos mentais, à nossa inteligência segundo a faculdade de julgar reflexiva, o que, Kant chama de "princípio da conformidade a fins da natureza" (Zweckmässigkeit), do qual dir-se-á, permite uma adaptação organizada dos fenômenos à unidade da Razão. O princípio da conformidade a fins da natureza subsume outro princípio, ou seja, um princípio que especifica as coisas, objetos, por que estes se ordenam e se adaptam às nossas ações, segundo uma escala de gêneros e espécies o que nos remeteria ao conceito de classe referenciado no início deste capítulo.

A aplicação do princípio de conformidade a fins da natureza, aos objetos empíricos, se faz em um juízo reflexivo, pois a faculdade julgar não é determinante, não provoca elementos novos; os fenômenos seriam aí representados já universalizados, trazidos à consciência, ou seja, como objetos; o referido princípio projeta-se reflexivamente sobre os mesmos objetos, constituindo-se numa regra a priori, para o uso reflexivo da faculdade de julgar.

A consideração da "Faculdade de Julgar" é essencial ao agir pericial, pois, o médicolegista no seu cotidiano a exerce na maioria das vezes dentro de um automatismo que possibilita seu uso no dia a dia, no entanto, deste automatismo geram-se também equívocos quando o pensar do perito não se fundamenta em Doutrina sólida que explique e torne cristalino o fenômeno, revelando-o.

A Doutrina em Medicina Legal em nosso entendimento deve ser fundamentada na ambiência da Filosofia das Ciências por intermédio das idéias claras e distintas e assim, promover a imposição dos conceitos científicos aos documentos médico-legais e por extensão e desígnio influir determinantemente na ambiência da Justiça. No dizer de Lalande (1999: 276), a respeito de Doutrina:

A).Sentido primitivo: ensino. "Há duas espécies de métodos, um para descobrir a verdade, que se chama análise... e que se pode chamar também método de invenção; o outro, para fazer com que seja entendido pelos outros quando é encontrado, que se chama síntese... e que se pode também chamar método de doutrina". (Lógica de Port Royal, $4^{\mathrm{a}}$ parte, cap. II). B). O que se 
ensina; e por generalização o que se afirma ser verdadeiro em matéria teológica, filosófica ou científica, implicando este termo sempre a idéia de um corpo de verdades organizadas, solidárias e mesmo o mais das vezes ligadas à ação, não de uma asserção isolada ou de pura teoria. Ciência e doutrina têm fins diferentes: uma constata e explica, a outra julga e prescreve...

Fundamentado no que nos ensinam Aristóteles, Descartes, Kant, Popper, Granger e Piaget, este capítulo buscou demonstrar o quão essencial é o corpo doutrinário em uma Ciência, ainda mais, quando os referidos fundamentos são estabelecidos a partir dos legados destes filósofos e homens de Ciência. 


\section{CAPÍTULO III}

\section{PESQUISA}

Ancorados na necessidade (observe-se aqui o pensar aristotélico sobre o necessário) apodítica do fazer-se ciência, elaboramos pesquisa em documentos médico-legais, com o objetivo de fundamentar o quão necessário se tornou para o organismo social uma consecução científica rigorosa dos referidos documentos.

Documento sensu lato é a representação grafada em determinado sistema de signos (por exemplo: um alfabeto), cujo desiderato é a apresentação de uma idéia, fato, fenômeno. $\mathrm{Na}$ ambiência da Medicina Legal, o documento é visto e pensado como texto escrito que transcreve a prova e demonstra assim o trabalho pericial, apresentando-o em linguagem apropriada, com o fim precípuo de orientar processo legal que se fundamente na prova científica.

Para França (2008: 21), dentro do trabalho pericial, papel essencial é advindo dos documentos médico-legais, pois, em suas várias nuances, além de apresentar a conclusão da perícia, ele pode validar ou invalidar o agir pericial e, neste caso, tornando imprestável a 
prova. Veja-se como o autor às páginas acima referidas traduz o seu entendimento sobre o tema:

Documento é toda anotação escrita que tem a finalidade de reproduzir e representar uma manifestação do pensamento. No campo médico-legal da prova, são expressões gráficas, públicas ou privadas, que têm o caráter representativo de um fato a ser avaliado em juízo. Os documentos, de interesse da Justiça, são: as notificações, os atestados, os relatórios e os pareceres (grifo do autor); além desses, os esclarecimentos não escritos no âmbito dos tribunais, constituídos pelos depoimentos orais.

A nossa pesquisa foi realizada tendo por base os denominados relatórios médicolegais, ou seja, os laudos e os autos, sendo que no primeiro tipo, o documento é da lavra do próprio perito e, no segundo, o perito dita para o escrivão de polícia as observações dos eventos, diante de testemunha.

O relatório médico-legal é elaborado obedecendo ao seguinte modelo oficial:

Preâmbulo: nesta parte do documento constam: data do exame pericial, local, repartição pública de origem, nome da autoridade pública que o solicitou, titulação e endereços dos peritos e a qualificação do periciando.

Quesitos: quando se trata das ações penais, território onde mais freqüentemente atua o perito médico-legal, existem os assim chamados quesitos oficiais, que, no entanto, não limitam a elaboração de outros questionamentos por parte da autoridade, os chamados quesitos acessórios. Na perícia cível e na Psiquiatria Médico-Legal não existem os referidos quesitos periciais.

Histórico: é a parte do relatório médico-legal que mais se aproxima do denominado "método clínico" do trabalho do médico, pois se fundamenta nos preceitos da Semiologia Médica, que obedece, desde os tempos hipocráticos, a necessidade de se ter conhecimento da origem de sintomas e sinais que anunciam a doença. Na ambiência da Medicina Legal, o histórico revela os registros de fatos, eventos que têm início no periciando. No entanto, cabe à perspicácia do perito o separar nesta hora o que tem relevância e o que não a tem. $O$ perito pode inclusive ouvir testemunhos, observar outros elementos que o auxiliem na consecução do laudo pericial. O histórico supre na prática médico-pericial muitas vezes o não estar presente no "local do crime ou do evento suspeito", ajustando assim o pensar do perito à prática científica da construção do documento específico, ou seja, o laudo pericial. 
Descrição: para todos os autores da Medicina Legal, este é o momento crucial da elaboração do laudo pericial. Fica-se diante do repto pericial mais evidente, portanto, do visum et repertum, o ver e reportar ou relatar, que nascido no século XVI, permeia até os dias atuais o trabalho pericial na construção do laudo. O magistrado, promotor, advogado que restringir o contato com o laudo à conclusão e resposta aos quesitos, nada entenderá, não fundamentará, não fará uma boa prática, sob a ótica da operação do Direito. Não pode o perito simplesmente citar uma lesão, evento, pois esta posição tem um viés reducionista incompatível com a prática científica. Deve o perito abordar o evento médico-legal da mesma forma como foi referido no capítulo sobre a Doutrina, ao tratar do fenômeno em Kant. É necessária a minúcia, o cuidado, a capacidade de estabelecer pelo menos inferência, ver, rever, avaliar e por fim relatar com toda riqueza de detalhes possíveis. Para França (2008: 24), "a finalidade do laudo médico-legal é oferecer à autoridade julgadora elementos de convicção para aquilo que ela supõe, mas de que necessita se convencer. A essência da perícia é dar a imagem mais aproximada possível do dano e do seu mecanismo de ação, do qual a lesão foi resultante". Nesta parte da elaboração do laudo pericial é que ficam mais evidentes as presenças da arethé e da techné aristotélicas, quando o referido documento é bem elaborado.

Discussão: embora muito importante, por permitir o exercício da dúvida, da possibilidade de contemplar-se a hipótese rival, da verificação das relações entre o/s evento/s, este item nem sempre é contemplado nos documentos médico-legais. Vale ressaltar a discussão dos diversos elementos contidos no laudo pericial, que deve afastar meras conjecturas pessoais e centrar-se na consulta aos referenciais teóricos e na ligação entre os diversos conceitos com os fenômenos ali analisados. Vê-se, por estas possibilidades, a importância do item Discussão no bojo do documento denominado laudo médico-legal.

Conclusão: nesta etapa, utiliza-se dos elementos analisados na descrição e na discussão, para a promoção de síntese que permita o desiderato do agir pericial. O cuidado que deve ser observado ao ler-se um laudo pericial é o fugir-se à prática comum de dedicar-se atenção extrema à conclusão e com isso deixar-se escapar toda a visão de detalhes que permitem, estes sim, a compreensão do evento ou eventos periciados.

Respostas aos quesitos: o término de um laudo em nosso meio é feito através de respostas sucintas, muitas vezes afirmações ou negações, em rol de quesitos previamente definidos pelo Estado. É claro que pode ocorrer, em algumas circunstâncias, quesitos outros, 
diversos dos chamados "quesitos oficiais", porém, isso ocorre na excepcionalidade, o que pode nos levar a ver um certo pré-determinismo latente e que decorre da própria legislação pátria. O perito não pode ficar restrito à simples condição de responder a tais quesitos, ou ainda a outros, sob pena de aplicar-se ao agir pericial um reducionismo inaceitável. Daí, a importância do item discussão, onde o perito pode evoluir as explicações e demonstrações pertinentes a cada caso ou fenômeno.

Foram escolhidos cinco (5) tipos de exames ou laudos médico-legais, devido a sua freqüência: Laudo de exame de corpo de delito (conjunção carnal), Exame clínico para verificação de embriaguez, Laudo de exame de corpo de delito (exame necroscópico), Laudo de exame de corpo de delito (lesão corporal), Laudo de exame de corpo de delito (ato libidinoso).

Os quesitos oficiais a serem respondidos pelos peritos no Laudo de exame de corpo de delito (conjunção carnal) são os seguintes: $1^{\circ}$ - Houve conjunção carnal? $2^{\circ}$ - Qual a data provável dessa conjunção? $3^{\circ}$ - Era virgem a paciente? $4^{\circ}$ - Houve violência para essa prática? $5^{\circ}$ - Qual o meio dessa violência? $6^{\circ}$ - Da violência resultou para a vítima: incapacidade para as ocupações habituais por mais de trinta dias ou perigo de vida, ou debilidade permanente de membro, sentido ou função, ou aceleração de parto, ou incapacidade permanente para o trabalho, ou enfermidade incurável, ou perda ou inutilização de membro, sentido ou função, ou deformidade permanente, ou aborto? $7^{\circ}$ - É a vítima alienada ou débil mental? $8^{\circ}$ - Houve qualquer outra causa que tivesse impossibilitado a vítima de resistir?

Os quesitos a serem respondidos pelos peritos no Exame clínico para verificação de embriaguez são os seguintes: $1^{\circ}$ - Há sintomas indicativos de que o paciente ingeriu bebida alcoólica? 2 $2^{\circ}$ - Em consequiência, ele está embriagado? $3^{\circ}$ - Qual a substância que provavelmente produziu a embriaguez? $4^{\circ}$ No estado em que se encontra, coloca em perigo a segurança própria ou alheia?

Os quesitos a serem respondidos pelos peritos no Laudo de exame de corpo de delito (exame necroscópico) são os seguintes: $1^{\circ}$ - Houve morte? $2^{\circ}$ - Qual a causa? $3^{\circ}$ - Qual a natureza do agente, instrumento ou meio que a produziu? $4^{\circ}$ - Foi produzida por meio de veneno, fogo, explosivo, asfixia ou tortura, ou por outro meio insidioso ou cruel? 
Os quesitos a serem respondidos pelos peritos no Laudo de exame de corpo de delito (lesão corporal) são os seguintes: $1^{\circ}$ - Há ofensa à integridade corporal ou á saúde do examinado? $2^{\circ}$ - Qual a natureza do agente, instrumento ou meio que a produziu? $3^{\circ}$ - Foi produzida por meio de veneno, fogo, explosivo, asfixia ou tortura, ou por outro meio insidioso ou cruel? $4^{\circ}$ - Resultará incapacidade para as ocupações habituais por mais de trinta dias; ou perigo de vida; ou debilidade de membro, sentido ou função; ou antecipação de parto? $5^{\circ}$ Resultará incapacidade permanente para o trabalho; ou enfermidade incurável; ou perda de membro, sentido ou função; ou deformidade permanente ou aborto?

Os quesitos a serem respondidos pelos peritos no Laudo de exame de corpo de delito (ato libidinoso) são os seguintes: $1^{\circ}$ - Houve a prática de ato libidinoso? $2^{\circ}$ - Em que consistiu? $3^{\circ}$ - Houve violência? $4^{\circ}$ - Qual o meio empregado? $5^{\circ}$ - Da violência resultou para a vítima: incapacidade para as ocupações habituais por mais de trinta dias ou perigo de vida, ou debilidade permanente de membro, sentido ou função, ou aceleração de parto, ou incapacidade permanente para o trabalho, ou enfermidade incurável, ou perda de membro, sentido ou função, ou deformidade permanente, ou aborto? $6^{\circ}$ - É a vítima alienada ou débil mental? $7^{\circ}$ - Houve qualquer outra coisa que tivesse impossibilitado a vítima de resistir?

A presente pesquisa teve como objetivo analisar 996 documentos médico-legais (Laudos), de domínio público, de Institutos Médico-Legais do Brasil.

O processo analítico teve como referência teórica as óticas aristotélica e kantiana, em que um determinado juízo de natureza atributiva revela o predicado contido no sujeito. Para Lalande (1999: 62), "Método analítico" foi utilizado por Hamelin para designar o conjunto de procedimentos lógicos que "é ou parece ser em quase toda a parte seguido pelo pensamento comum", juízo indução, silogismo. "Ele o opõe ao "método sintético" que progride através de tese, antítese, síntese."

Após processo analítico acurado sobre todos os elementos que compõem os documentos médico-legais pesquisados, pode-se chegar às "categorias", tanto na ótica aristotélica onde se podem encontrar as diferentes "classes do ser", quanto aos diferentes predicados que se podem afirmar de um sujeito. Considere-se ainda a ótica kantiana, onde as referidas categorias são os conceitos fundamentais do Entendimento puro, portanto, formas $a$ priori do nosso conhecimento, que representam todas as funções substanciais do discurso 
deduzidas da natureza do juízo considerado nas suas quatro modalidades: quantidade, qualidade, relação e modalidade.

As categorias, nesta pesquisa, estão denotadas (aqui, termo que designa a extensão de um conceito, leia-se "extensão no sentido cartesiano"), em quatro tipos específicos: Inadequação e Imprecisão do vocabulário técnico, Inadequação dos conceitos em Medicina Legal, Nexo causal prejudicado e Laudo insuficiente.

A categoria denotada pelos termos "inadequação e imprecisão" das palavras de uso corrente na ambiência da Medicina Legal, nos remete ao que é entendido pelos termos “adequação e precisão". O primeiro termo representa a conformidade entre um conhecimento e o objeto correspondente, no mundo concreto. O segundo termo representa, por sua vez, a escolha exata das palavras e construções que expressem com fidelidade um evento, pensamento, fenômeno. A inadequação e a imprecisão serão os opostos dos termos anteriormente citados, ou seja, a ausência de adequação caracteriza o primeiro termo e caráter daquilo que é impreciso caracteriza o segundo. O problema surge da inadequação e da imprecisão do vocabulário técnico que o perito usa na construção do documento médico-legal, que orienta processos legais.

A inadequação dos conceitos em Medicina Legal nos remete ao Entendimento kantiano do que seja conceito, "unidade mental do múltiplo", já devidamente discutido no capítulo sobre a Doutrina, nesta Tese.

O conceito de "Nexo causal" remete o perito às condições necessárias e suficientes que relacionam uma causa ao seu efeito.

O quarto tipo destas categorias, ou seja, o "Laudo insuficiente" remete em uma determinada análise, ao que é escasso, insuficiente, pouco. Portanto, não atinge ao desiderato do agir pericial que nos pede o contrário.

Diante de laudos médico-legais que informam, por exemplo: "hematoma no seio esquerdo, equimoses no joelho direito, região anal com ausência de fissuras ou rágades na mucosa anal, esfincter anal com tonicidade normal" - lesões estas transcritas de laudo de exame de corpo de delito (Ato libidinoso), pode-se, além de dar outra interpretação ao exposto, ainda não perceber a inadequação e imprecisão do vocabulário técnico utilizado? 
Prosseguindo com as citações de documentos médico-legais, veja-se este outro exemplo: "ausência de trauma, hematoma ou ferimento na região anal; ao toque esfíncter pérvio sem qualquer sinal de corte anal", está evidente em ambas as situações a inadequação e imprecisão do vocabulário técnico que o perito deve evitar na consecução de seu trabalho.

Em outro documento, o texto continha a seguinte "construção verbal": "a paciente supra, foi vítima de mordida de cão, o exame constatou: pequena escoriação na região da nádega direita, produzida pelo instrumento "mordida de cão". Onde se encontra o conceito de ação vulnerante corto-contundente neste caso? Ou ainda, em outro exemplo: "paciente apresenta várias cicatrizes de ferimentos corto-contundentes na região nasal e mentoniana, produzidas por agressão física", onde está novamente o conceito de agente vulnerante?

Observe-se este outro texto de laudo médico-legal constante em nossa pesquisa: "paciente apresenta várias cicatrizes de ferimentos corto-contusos na região nasal direita, mentoniana direita e no joelho direito, produzido por instrumento contundente" - onde está presente a adequação conceitual de instrumento corto-contundente, instrumento contundente, lesão corto-contusa, lesão contusa, e ainda pior: o que significa "região mentoniana direita", em anatomia humana? Veja-se este outro texto pericial pesquisado: "paciente apresenta cicatriz cirúrgica em abdome inferior cicatrizada e ainda cicatriz em região nasal por ferimento corto-contuso, cujo agente foi de natureza contundente" - novamente se está diante de evidente imprecisão conceitual, além de óbvia exigüidade de elementos informativos da real situação do examinando. Segue-se outro texto pericial: "paciente apresenta equimose em região mamária direita, laudo positivo para atos libidinosos, (chupada)", ora, equimose é lesão corporal decorrente de ação de instrumento contundente, se realmente houve ruptura capilar decorrente da referida "chupada", a lesão é denominada de sugilação, novamente se está diante de evidente inadequação conceitual e imprecisão do nexo causal.

Estes exemplos repetem-se ad nauseam, senão vejamos: "ao exame constatou-se ferimento corto-contuso em região frontal e orelha direita, produzido por instrumento contundente"; "vítima de acidente automobilístico que apresenta: ferimento corto-contuso na região occipital direita com sutura e hematoma de coxa esquerda, produzidos por instrumento contundente"; "ao exame externo apresenta escoriações no couro cabeludo na região occipital e nas costas, hematoma no braço direito. Realizada inspeção bimastoidea vertical e retirado a calota craniana pela técnica de Griesinger notamos: extensa fratura do osso occipital e parietal 
direito indo em direção ao osso parietal esquerdo e temporal direito, notamos extravasamento de massa encefálica na região occipito-parietal direita. Exame do tórax e do abdome sem interesse. Causa mortis: hemorragia cerebral por fratura do crânio". Estas últimas transcrições de documentos médico-legais de nossa Pesquisa, mais uma vez confirmam a evidente inadequação de conceitos já estabelecidos na Medicina Legal, além da imprecisão de referências anatômicas e imprecisão do nexo causal.

O que se dizer do seguinte texto: "paciente está fazendo pré-natal, o exame revelou conjunção carnal antiga" - em uma só frase, tantas imprecisões e inadequações técnicas, e quanta insuficiência de informação, que caracteriza a categoria por nós denominada de laudo insuficiente. Veja-se este outro exemplo: "paciente em posição genupeitoral: nada de interesse médico-legal”, ou ainda este: "colocado em posição genupeitoral: ânus sem interesse médicolegal", este outro: "ao exame constatamos: traumatismo em joelho esquerdo, apresentando também hálito etílico, concluímos que o paciente apresenta lesões leves”, veja-se este outro: "ao exame: ferida pérfuro-contusa na região torácica antero-inferior do hemitórax esquerdo com perfurações de alças intestinais e do pulmão esquerdo", este também: "vítima de agressão física, ao exame constatamos: ferimento corto-contuso em cotovelo esquerdo, em mucosa de lábio inferior, produzidos por instrumento contundente".

Tais exemplos consolidam a necessidade da presente pesquisa, dada a exuberância da inadequação, imprecisão, insuficiência dos elementos fenomênicos ali presentes, que impedem o nexo causal e, portanto, invalidam os referidos documentos, tornando-os imprestáveis para o desiderato pericial, ou seja, constituir a prova, no caso da Medicina Legal, a prova científica.

Apresentamos a seguir as Tabelas dos documentos médico-legais pesquisados, novecentos e noventa e seis (996) laudos médico-legais, que foram tratados estatisticamente.

Antes de apresentarmos as referidas Tabelas é necessário explicar-se a construção das mesmas. Após a devida análise chegamos as Categorias qualitativas já definidas acima: Inadequação e imprecisão do vocabulário técnico, Inadequação dos conceitos, Nexo causal prejudicado e Laudo insuficiente. Estas categorias foram numeradas em ordem crescente de 1 até 4.

1 - Inadequação e imprecisão do vocabulário técnico. 
2 - Inadequação dos conceitos.

3 - Nexo causal prejudicado.

4 - Laudo insuficiente.

Como diversos laudos apresentavam caracteres que os classificavam em mais de uma categoria, foram criadas outras categorias que contemplassem essas intersecções.

Para determinar o número de categorias que contemplassem as intersecções entre duas categorias, calculou-se o número de combinações simples de quatro categorias tomadas de duas em duas, através da seguinte fórmula:

$$
C_{4,2}=\left(\begin{array}{l}
4 \\
2
\end{array}\right)=\frac{4 !}{2 ! .2 !}=6
$$

Assim, obtiveram-se as categorias: 1e $2 ; 1$ e $3 ; 1$ e $4 ; 2$ e $3 ; 2$ e $4 ; 3$ e 4.

Para determinar o número de categorias que contemplassem as intersecções entre três categorias, calculou-se o número de combinações simples de quatro categorias tomadas de três em três, através da seguinte fórmula:

$$
C_{4,3}=\left(\begin{array}{l}
4 \\
3
\end{array}\right)=\frac{4 !}{3 ! .1 !}=4
$$

Assim, obtiveram-se as categorias: 1, 2 e 3; 1, 2 e 4; 1, 3 e 4; 2, 3 e 4; completou-se então, o conjunto de categorias pesquisadas com a intersecção das quatro categorias, ou seja, 1, 2, 3 e 4; e ainda uma última categoria onde foram considerados os "laudos suficientes". As categorias, o número de laudos e as devidas porcentagens dos mesmos estão relacionados a seguir em tabelas e gráficos: 


\begin{tabular}{ccc} 
Categorias & Laudos & $\%$ \\
\hline 1 & 23 & 7,10 \\
2 & 36 & 11,11 \\
3 & 7 & 2,16 \\
4 & 110 & 33,95 \\
1 e 2 & 8 & 2,47 \\
1 e 3 & 4 & 1,23 \\
1 e 4 & 9 & 2,78 \\
2 e 3 & 15 & 4,63 \\
2 e 4 & 4 & 1,23 \\
3 e 4 & 1 & 0,31 \\
1,2 e 3 & 5 & 1,54 \\
1,2 e 4 & 2 & 0,62 \\
1,3 e 4 & 1 & 0,31 \\
2,3 e 4 & 1 & 0,31 \\
$1,2,3$ e 4 & 10 & 3,09 \\
Suficientes & 88 & 27,16 \\
\hline & 324 & 100,00
\end{tabular}

Tabela 1 - Número de laudos pesquisados de Lesão Corporal e suas respectivas frequiências relativas

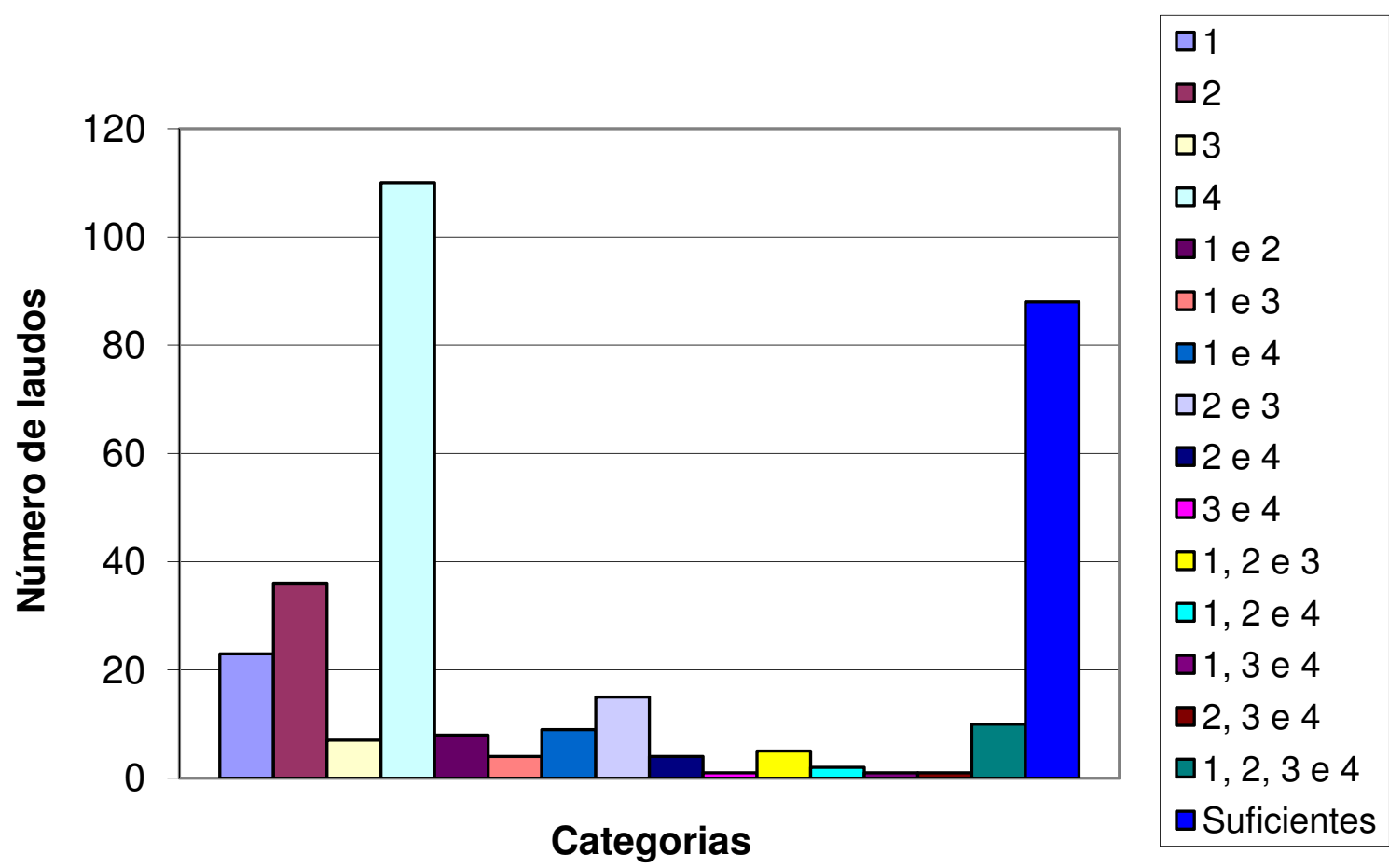

$=$

Figura 1 - Histograma correspondente aos laudos de Lesão Corporal 


\begin{tabular}{ccc} 
Categorias & Laudos & $\%$ \\
\hline 1 & 15 & 7,18 \\
2 & 23 & 11,00 \\
3 & 1 & 0,48 \\
4 & 65 & 31,10 \\
1 e 2 & 7 & 3,35 \\
1 e 3 & 0 & 0,00 \\
1 e 4 & 4 & 1,91 \\
2 e 3 & 2 & 0,96 \\
2 e 4 & 4 & 1,91 \\
3 e 4 & 0 & 0,00 \\
1,2 e 3 & 1 & 0,48 \\
1,2 e 4 & 0 & 0,00 \\
1,3 e 4 & 0 & 0,00 \\
2,3 e 4 & 0 & 0,00 \\
$1,2,3$ e 4 & 7 & 3,35 \\
Suficientes & 80 & 38,28 \\
\hline & 209 & 100,00
\end{tabular}

Tabela 2 - Número de laudos pesquisados de Conjunção Carnal e suas respectivas frequiências relativas

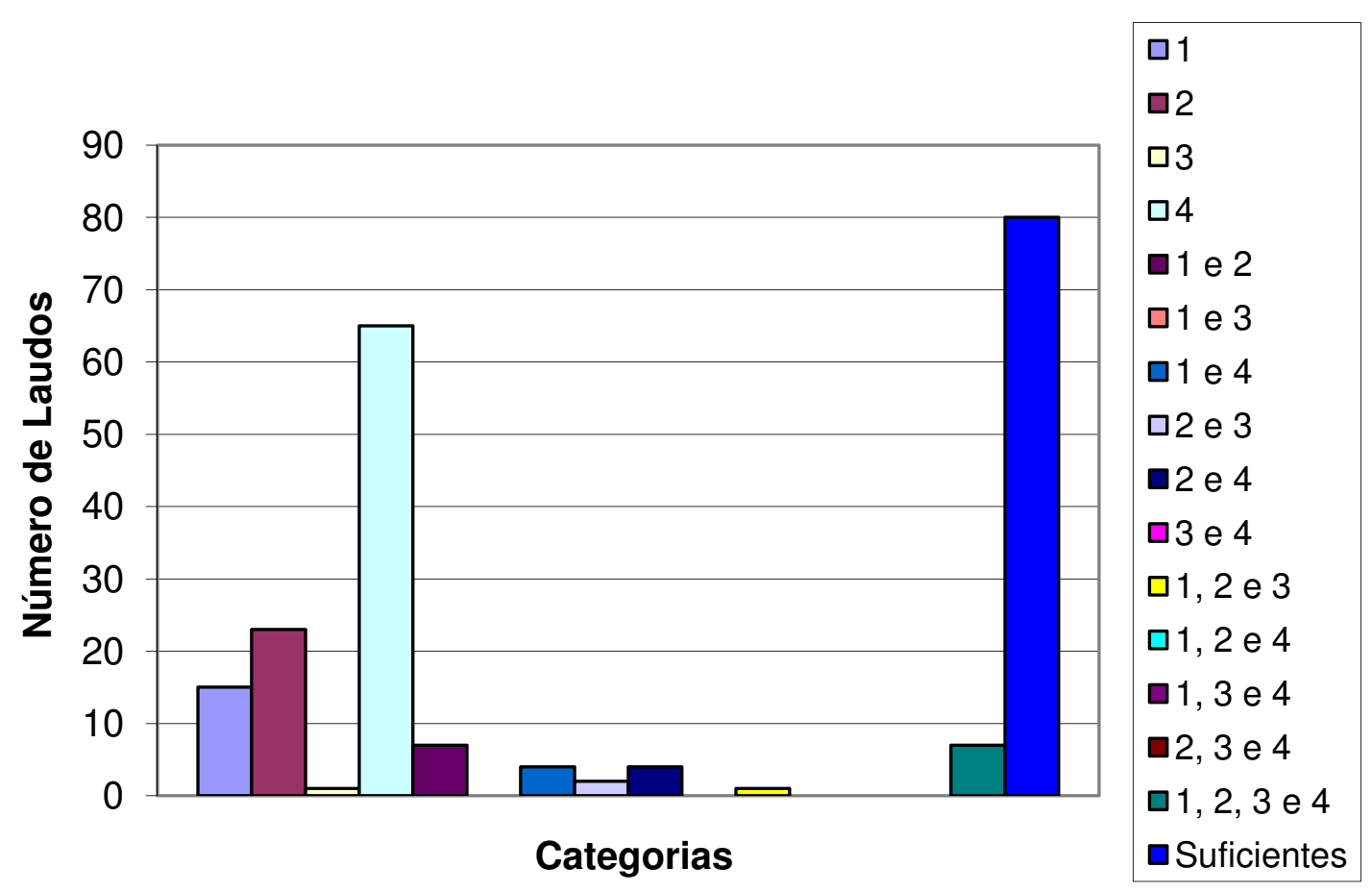

Figura 2 - Histograma correspondente aos laudos de Conjunção Carnal 


\begin{tabular}{ccc} 
Categorias & Laudos & $\%$ \\
\hline 1 & 9 & 4,59 \\
2 & 3 & 1,53 \\
3 & 1 & 0,51 \\
4 & 62 & 31,63 \\
1 e 2 & 4 & 2,04 \\
1 e 3 & 0 & 0,00 \\
1 e 4 & 2 & 1,02 \\
2 e 3 & 3 & 1,53 \\
2 e 4 & 4 & 2,04 \\
3 e 4 & 3 & 1,53 \\
1,2 e 3 & 2 & 1,02 \\
1,2 e 4 & 0 & 0,00 \\
1,3 e 4 & 7 & 3,57 \\
2,3 e 4 & 4 & 2,04 \\
$1,2,3$ e 4 & 28 & 14,29 \\
Suficientes & 64 & 32,65 \\
\hline & 196 & 100,00
\end{tabular}

Tabela 3 - Número de laudos pesquisados de Exames Necroscópicos e suas respectivas freqüências relativas

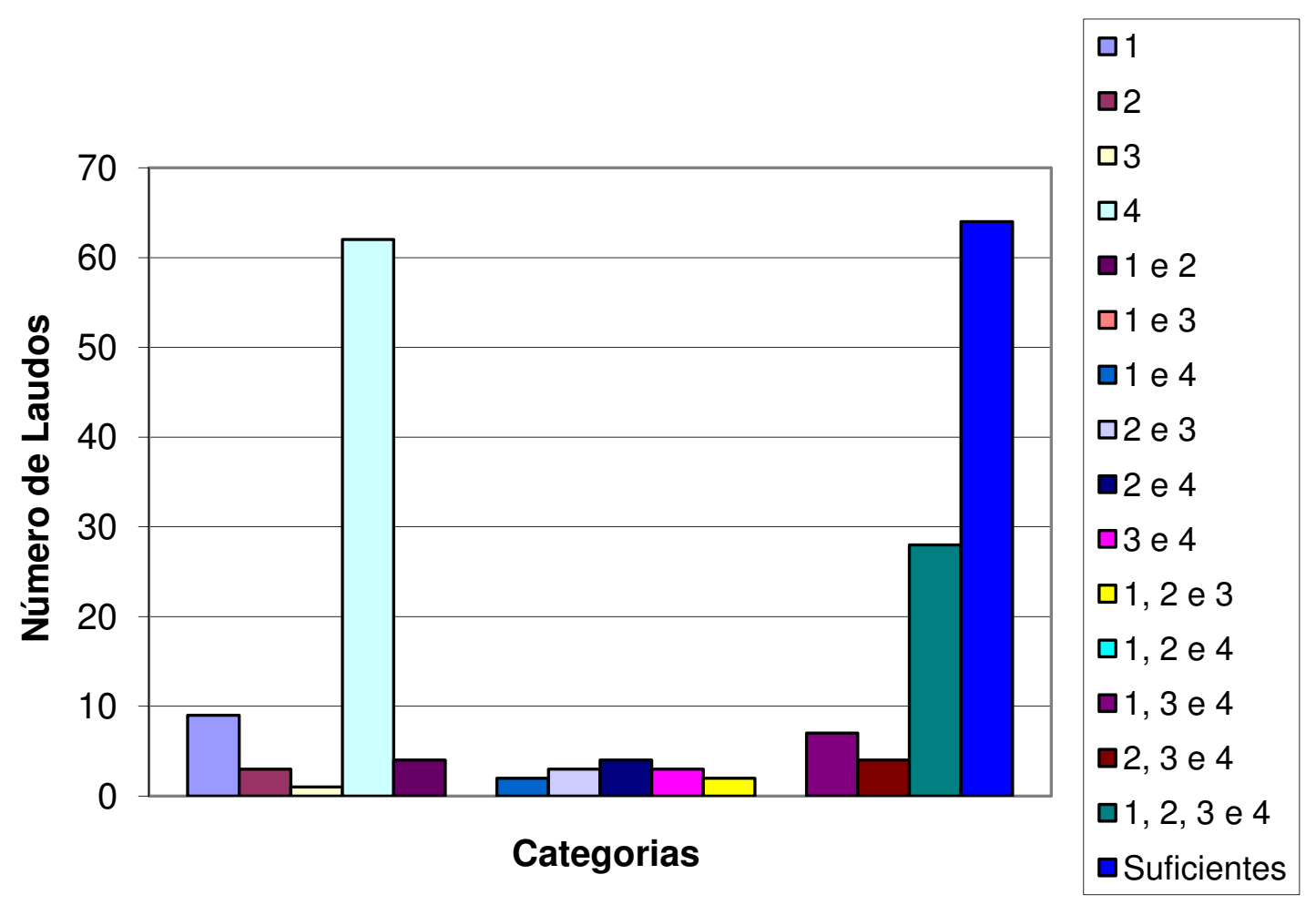

Figura 3 - Histograma correspondente aos laudos de Exames Necroscópicos 


\begin{tabular}{ccc} 
Categorias & Laudos & $\%$ \\
\hline 1 & 11 & 6,67 \\
2 & 3 & 1,82 \\
3 & 1 & 0,61 \\
4 & 70 & 42,42 \\
1 e 2 & 2 & 1,21 \\
1 e 3 & 3 & 1,82 \\
1 e 4 & 4 & 2,42 \\
2 e 3 & 2 & 1,21 \\
2 e 4 & 2 & 1,21 \\
3 e 4 & 1 & 0,61 \\
1,2 e 3 & 2 & 1,21 \\
1,2 e 4 & 1 & 0,61 \\
1,3 e 4 & 1 & 0,61 \\
2,3 e 4 & 1 & 0,61 \\
$1,2,3$ e 4 & 4 & 2,42 \\
Suficientes & 57 & 34,55 \\
\hline & 165 & 100,00
\end{tabular}

Tabela 4 - Número de laudos pesquisados de Verificação de Embriaguez e suas respectivas freqüências relativas

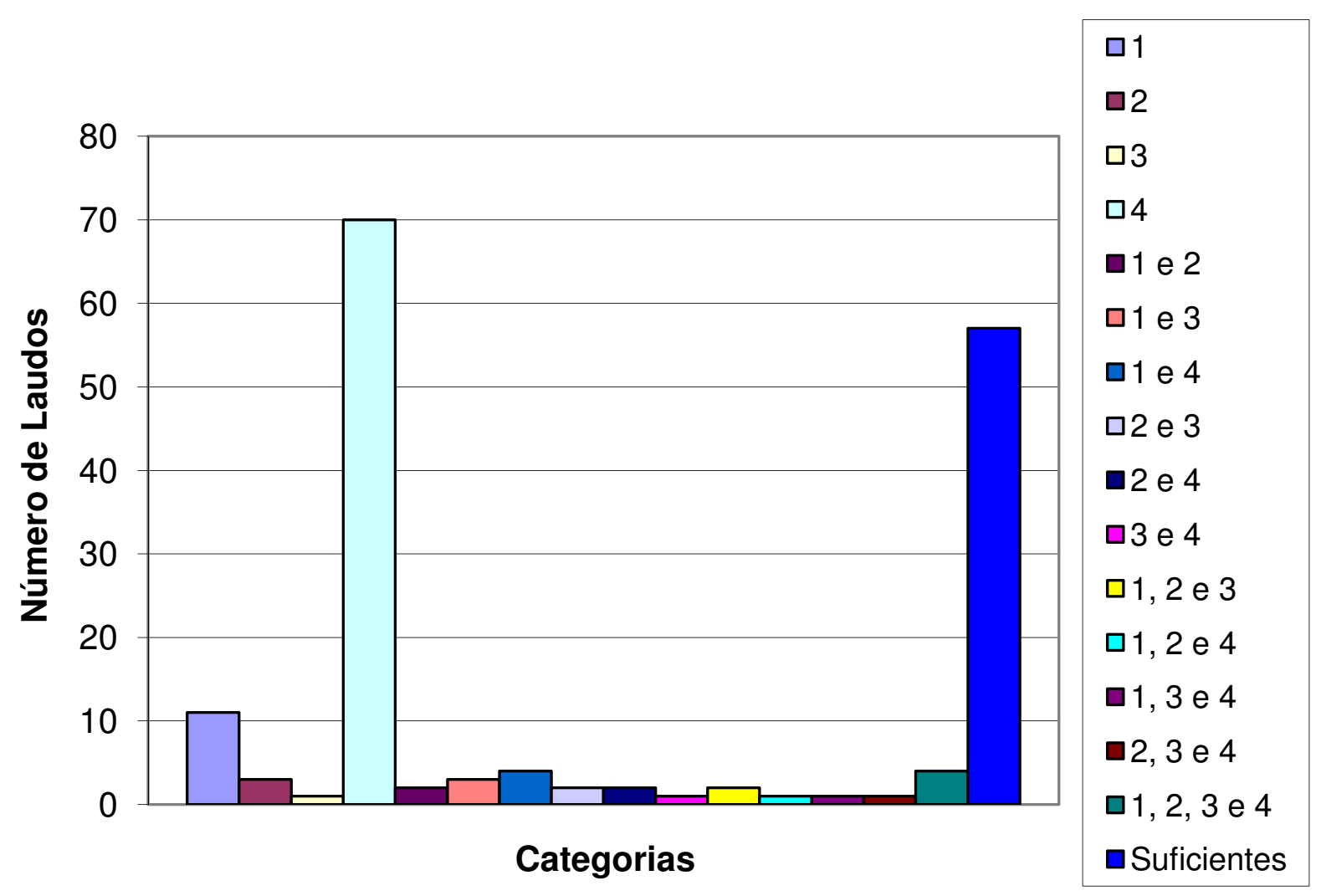

Figura 4 - Histograma correspondente aos laudos de Verificação de Embriaguez 


\begin{tabular}{ccc} 
Categorias & Laudos & $\%$ \\
\hline 1 & 6 & 5,88 \\
2 & 9 & 8,82 \\
3 & 0 & 0,00 \\
4 & 26 & 25,49 \\
1 e 2 & 2 & 1,96 \\
1 e 3 & 1 & 0,98 \\
1 e 4 & 1 & 0,98 \\
2 e 3 & 1 & 0,98 \\
2 e 4 & 1 & 0,98 \\
3 e 4 & 1 & 0,98 \\
1,2 e 3 & 0 & 0,00 \\
1,2 e 4 & 0 & 0,00 \\
1,3 e 4 & 2 & 1,96 \\
2,3 e 4 & 0 & 0,00 \\
$1,2,3$ e 4 & 1 & 0,98 \\
Suficientes & 51 & 50,00 \\
\hline & 102 & 100,00
\end{tabular}

Tabela 5 - Número de laudos pesquisados de Exame de Ato Libidinoso e suas respectivas frequiências relativas

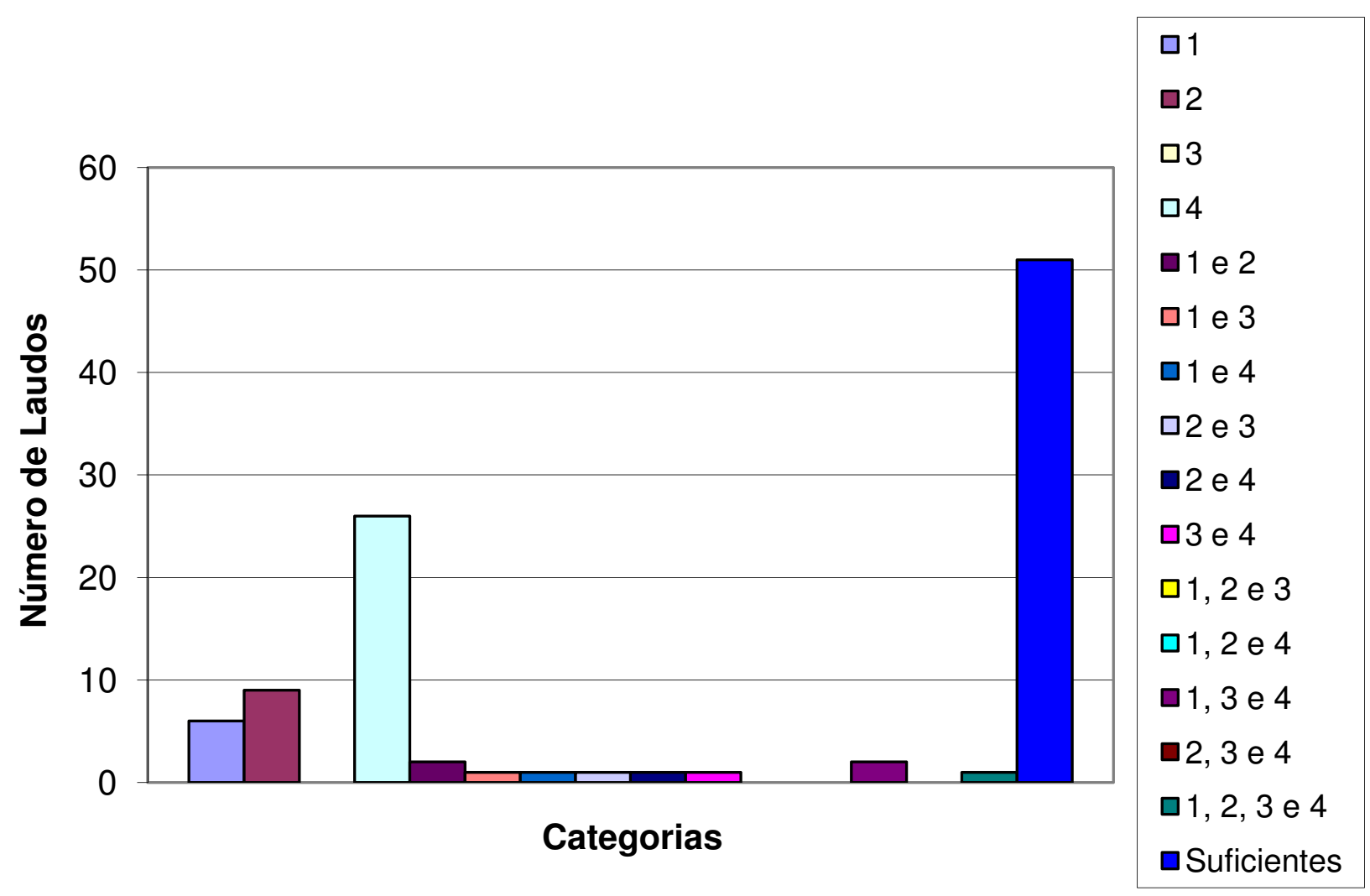

Figura 5 - Histograma correspondente aos laudos de Exame de Ato Libidinoso 
Do instrumento estatístico:

Escolhemos para trabalhar os elementos colhidos na pesquisa, pesquisa esta realizada em 996 laudos médico-legais de diversas regiões do país, os exames, ora apresentados na seqüência desta estatística, que foram os seguintes: Laudo de Exame de Corpo de Delito (Lesão corporal); Laudo de Exame de corpo de delito (Conjunção carnal); Laudo de Exame de corpo de delito (Exame necroscópico); Exame clínico para verificação de embriaguez; Laudo de Exame de corpo de delito (Ato libidinoso).

A estatística escolhida foi o Teste de qui-quadrado clássico, pois os dados que foram trabalhados são categóricos, já que correspondem à contagem de freqüência de uma variável classificada em categorias. Esta estatística é usada para testar a hipótese de que uma distribuição de freqüências observadas se ajusta a uma determinada distribuição teórica, com variáveis qualitativas, que é o presente caso.

Para Arango (2005: 226-227): os testes para dados categorizados são:

Dados categorizados referem-se à contagem de frequiência de uma variável classificada ou subdividida em categorias. Embora este procedimento seja típico de dados referentes a variáveis qualitativas, é possível também criar categorias para dados de variáveis quantitativas. (...) O objetivo dos testes para dados categorizados é determinar, segundo algum critério válido de decisão, se o fator discriminante exerce alguma influência sobre o fator discriminado.

A distribuição qui-quadrado $\chi^{2}$ tem as seguintes propriedades:

- A distribuição qui-quadrado não é simétrica, ao contrário da distribuição normal (gaussiana), conforme a Figura 6.

- Os valores da distribuição qui-quadrado podem ser (0) ou positivos, mas nunca negativos.

- Há uma distribuição qui-quadrado diferente para cada número de graus de liberdade. 


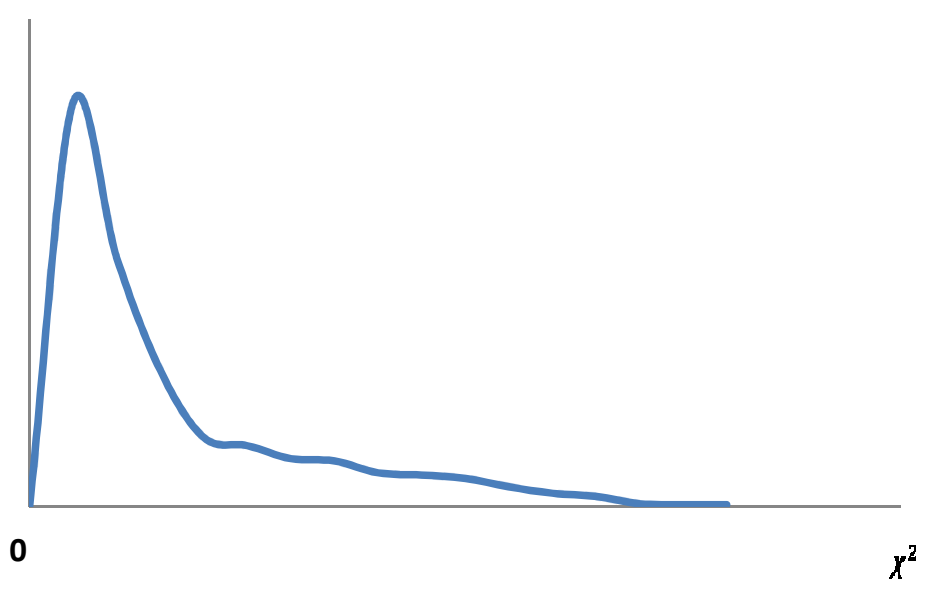

Figura 6 - A distribuição qui-quadrado, onde todos os valores são "não-negativos".

A presente pesquisa é fundamentada em frequiências amostrais, o que de forma típica, busca demonstrar possíveis afastamentos de valores que são teoricamente esperados. Estabelece-se então, a relação entre valores observados e valores esperados, estes sob a ótica teórica. Para se prolatar a referida relação, usam-se a seguinte estatística de teste, que torna possível medir a discrepância entre o observado e o esperado, estes enquanto frequiências, obedecendo à seguinte fórmula:

$$
\chi^{2}=\sum \frac{(O-E)^{2}}{E}
$$

onde $(O)$ representa a freqüência de valores observados e $(E)$ representa a freqüência de valores esperados.

A estatística de Teste qui-quadrado representa uma restrita concordância entre os valores acima denominados de "observados" e "esperados" se a magnitude dos mesmos é diminuta. Caso contrário, ou seja, quando o referido valor é de grande monta, a estatística aponta discordância entre os valores referidos. Então, diante do que usualmente se chama valor crítico, que depende do nível de significância que é representado pela letra ( e do número de graus de liberdade, rejeita-se ou não a hipótese nula, de que os valores esperados são iguais aos valores observados. Este valor crítico é usualmente obtido em instrumento denominado de "Tabela de distribuição de Qui-quadrado". 
A escolha desta estatística (Teste do qui-quadrado) deveu-se a situação específica da presente pesquisa que é baseada em dados qualitativos. Na aplicação deste Teste, foi considerada a Hipótese nula $\left(\mathrm{H}_{0}\right)$ onde as freqüências observadas são iguais as freqüências esperadas. Foi considerada ainda a Hipótese alternativa $\left(\mathrm{H}_{1}\right)$ onde ao menos uma das freqüências observadas é diferente da freqüência esperada correspondente.

O Nível de significância é a probabilidade de afirmar-se, que ao menos uma das freqüências observadas é diferente da freqüência esperada correspondente. Esse nível de significância está relacionado ao Grau de confiança que é a probabilidade de as frequiências esperadas serem iguais as frequiências observadas. Na aplicação do Teste (qui-quadrado) foram considerados os seguintes valores:

Nível de significância: $\propto=5 \%$

Grau de confiança: $\quad 1-\propto=95 \%$

Outro valor considerado é o número de Graus de liberdade que é $n-1$, onde $n$ é o número de categorias, no presente caso (16). São 15 (quinze) então, os graus de liberdade considerados.

A tomada de decisão de se rejeitar ou não a Hipótese nula $\left(\mathrm{H}_{0}\right)$ é feita de tal forma que:

- $\chi^{2} \leq V_{c} \rightarrow \mathrm{H}_{0}$ deve ser aceita

- $\chi^{2}>V_{c} \rightarrow \mathrm{H}_{0}$ deve ser rejeitada

onde $V_{c}$ é o Valor crítico que neste teste é de 24,996, que corresponde ao Nível de 0,05 de significância e 15 graus de liberdade. 
As freqüências esperadas utilizadas em nosso teste são as médias aritméticas das freqüências relativas de cada uma das 16 (dezesseis) categorias definidas, conforme indica a Tabela (6).

\begin{tabular}{|c|c|c|c|c|c|c|c|c|c|c|c|c|c|c|c|c|}
\hline Categorias & 1 & 2 & 3 & 4 & $1-2$ & 1-3 & 1- 4 & $2-3$ & $2-4$ & $3-4$ & $1-2-3$ & 1-2-4 & 1-3-4 & 2-3- 4 & 1-2-3-4 & Suficientes \\
\hline \multicolumn{17}{|l|}{ Grupos } \\
\hline A & 7,10 & 11,11 & 2,16 & 33,95 & 2,47 & 1,23 & 2,78 & 4,63 & 1,23 & 0,31 & 1,54 & 0,62 & 0,31 & 0,31 & 3,09 & 27,16 \\
\hline B & 7,18 & 11,00 & 0,48 & 31,10 & 3,35 & 0,00 & 1,91 & 0,96 & 1,91 & 0,00 & 0,48 & 0,00 & 0,00 & 0,00 & 3,35 & 38,28 \\
\hline $\mathrm{C}$ & 4,59 & 1,53 & 0,51 & 31,63 & 2,04 & 0,00 & 1,02 & 1,53 & 2,04 & 1,53 & 1,02 & 0,00 & 3,57 & 2,04 & 14,29 & 32,65 \\
\hline $\mathrm{D}$ & 6,67 & 1,82 & 0,61 & 42,42 & 1,21 & 1,82 & 2,42 & 1,21 & 1,21 & 0,61 & 1,21 & 0,61 & 0,61 & 0,61 & 2,42 & 34,55 \\
\hline $\mathrm{E}$ & 5,88 & 8,82 & 0,00 & 25,49 & 1,96 & 0,98 & 0,98 & 0,98 & 0,98 & 0,98 & 0,00 & 0,00 & 1,96 & 0,00 & 0,98 & 50,00 \\
\hline $\begin{array}{l}\text { Freqüências } \\
\text { esperadas }\end{array}$ & 6,28 & 6,86 & 0,75 & 32,92 & 2,21 & 0,81 & 1,82 & 1,86 & 1,48 & 0,69 & 0,85 & 0,24 & 1,29 & 0,59 & 4,83 & 36,53 \\
\hline
\end{tabular}

Tabela 6 - Cálculo das frequiências esperadas utilizadas nos testes de qui-quadrado.

As Categorias já estão definidas acima. Os Grupos constantes das tabelas correspondem aos seguintes tipos de documentos médico-legais analisados:

A) Laudo de exame de corpo de delito (Lesão corporal).

B) Laudo de exame de corpo de delito (Conjunção carnal)

C) Laudo de exame de corpo de delito (Exame Necroscópico)

D) Exame clínico de verificação de embriaguez.

E) Laudo de exame de corpo de delito (Ato libidinoso).

Para cada Grupo, as freqüências observadas utilizadas no teste são as freqüências relativas (percentuais) de cada uma das dezesseis categorias.

Aplicando-se a seguinte equação a cada Grupo obtêm-se a estatística $\chi^{2}$.

$$
\chi^{2}=\sum \frac{(O-E)^{2}}{E}
$$

A tabela 7 apresenta os resultados obtidos com a aplicação da equação acima, para cada um dos Grupos. 


\begin{tabular}{|c|c|}
\hline Grupos & \multicolumn{1}{|c|}{$\chi^{2}$} \\
\hline A & 15,58 \\
\hline B & 8,32 \\
\hline C & 34,04 \\
\hline D & 11,05 \\
\hline E & 14,25 \\
\hline
\end{tabular}

Tabela 7 - Estatísticas obtidas na aplicação do teste de qui-quadrado

As estatísticas obtidas no Teste de qui-quadrado para os Grupos: A, B, D e E são menores que o Valor crítico $\left(V_{c}=24,996\right)$, o que nos leva a aceitar a Hipótese nula para estes grupos.

A estatística obtida no Teste de qui-quadrado para o Grupo $\mathrm{C}$ é maior que o Valor crítico $\left(V_{c}=24,996\right)$, o que nos leva a rejeitar a Hipótese nula para este grupo. O que explica este resultado é o fato de que neste grupo a quantidade de dados (laudos necroscópicos) com os quatro tipos de erros é maior comparado aos demais grupos, como mostra a figura 7 , talvez pela maior complexidade e exigência de maiores conhecimentos para a consecução dos mesmos.

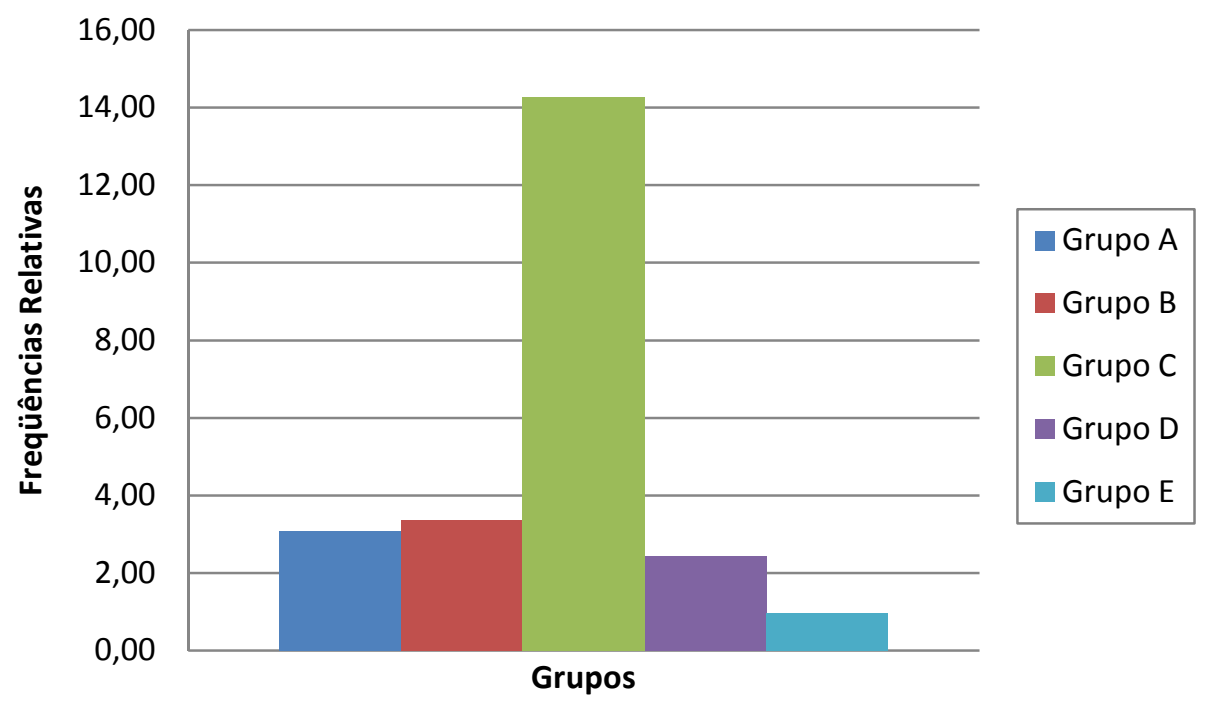

Figura 7 - Comparação da categoria "1, 2, 3 e 4" nos cinco grupos 
Podemos perceber graficamente que nos Grupos A, B, D e E as freqüências observadas convergem às freqüiencias esperadas.

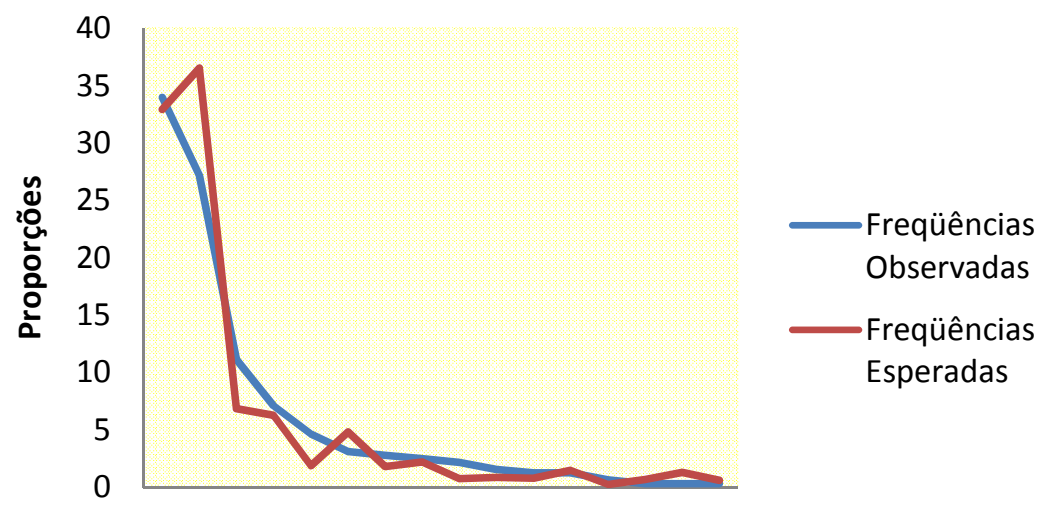

$\begin{array}{llllllllll}1 & 2 & 3 & 4 & 5 & 6 & 7 & 8 & 9 & 10111213141516\end{array}$

Categorias

Figura 8 - Comparação entre as Freqüências Esperadas e Freqüências Observadas nos laudos de Lesão Corporal.

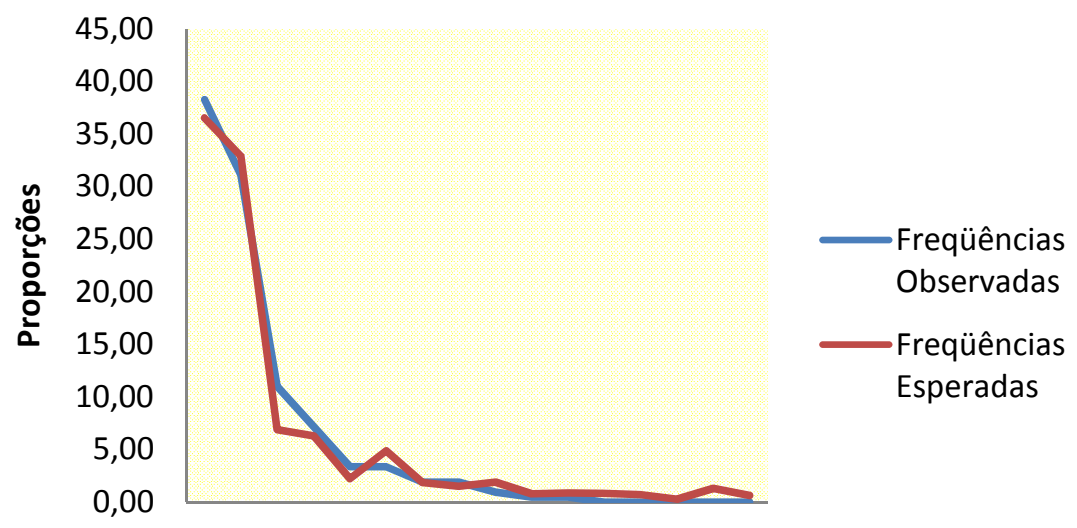

123445678910111213141516

Categorias

Figura 9 - Comparação entre as Frequiências Esperadas e Freqüências Observadas nos laudos de Conjunção Carnal. 


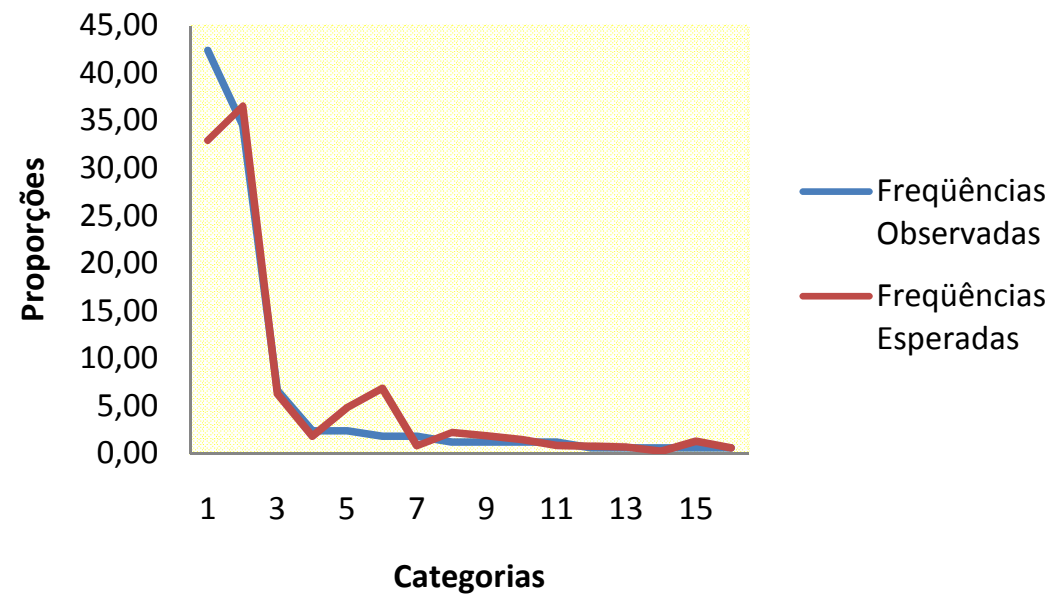

Figura 10 - Comparação entre as Freqüências Esperadas e Freqüências Observadas nos laudos de Verificação de Embriaguez.

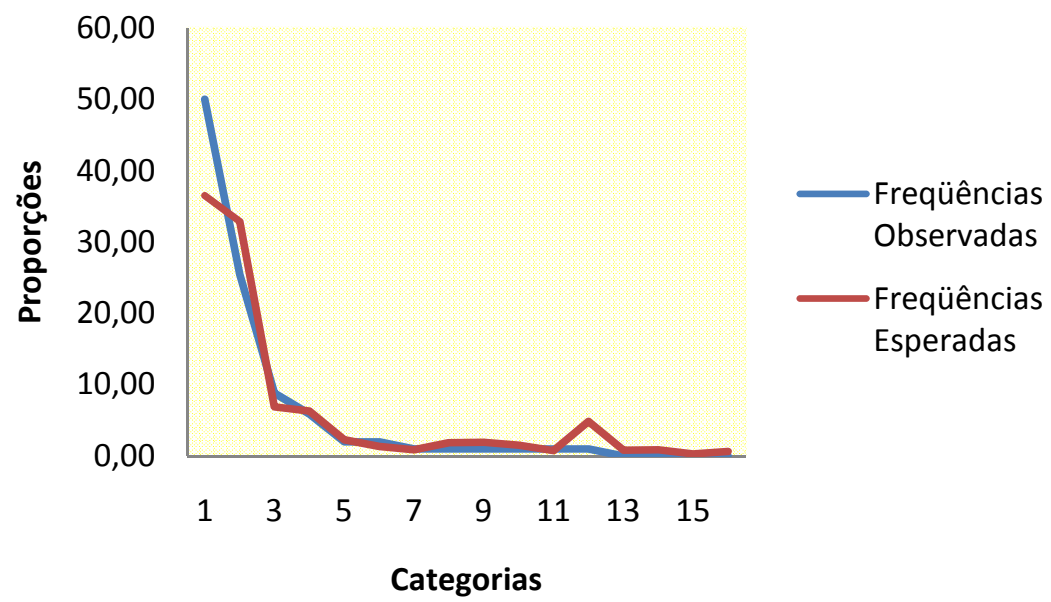

Figura 11 - Comparação entre as Freqüências Esperadas e Freqüências Observadas nos laudos de Ato Libidinoso. 
Podemos perceber que no Grupo $\mathrm{C}$ as freqüências observadas divergem das freqüências esperadas.

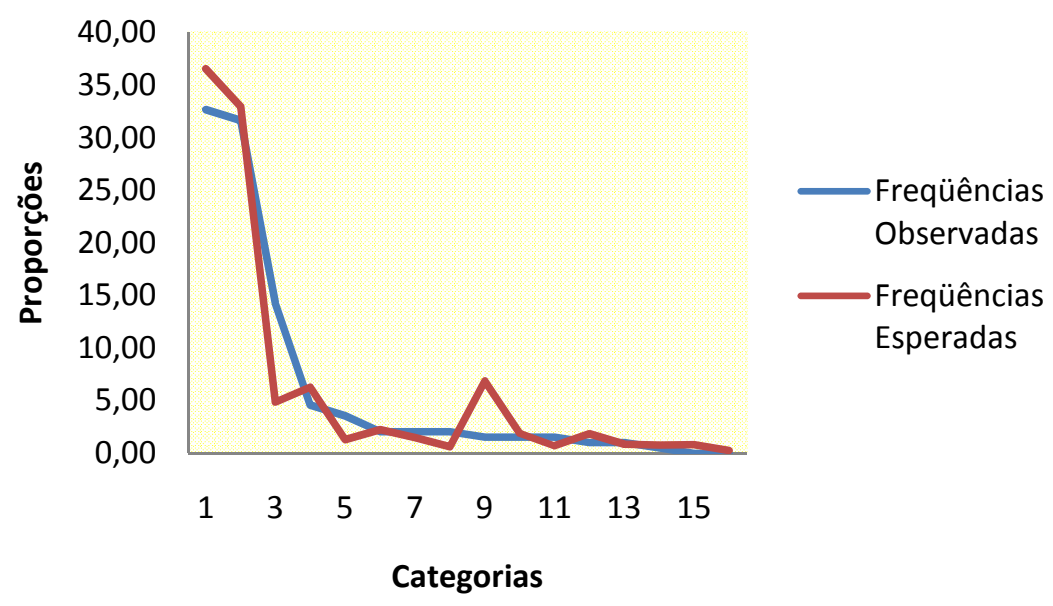

Figura 12 - Comparação entre as Frequiências Esperadas e Freqüências Observadas nos laudos de Exames Necroscópicos.

Podemos concluir que nos Grupos A, B, D e E é possível usar-se as freqüências observadas para estimar essas categorias em outras populações, por estar ajustada a distribuição qui-quadrado $\left(\chi^{2}\right)$. Enquanto para o Grupo $\mathrm{C}$ não se pode fazer afirmação semelhante pelo não ajustamento da amostra na distribuição qui-quadrado $\left(\chi^{2}\right)$.

A estatística se ocupa de reunir dados para deles obterem-se informações, ou conhecerem-se determinados aspectos dos grupos examinados. Na presente pesquisa ao se comparar as freqüências observadas e esperadas, observou-se que nos grupos A, B. D e E, estava ajustada a distribuição qui-quadrado $\left(\chi^{2}\right)$, enquanto no grupo $\mathrm{C}$ não havia o referido ajustamento. Pode-se inferir que nos grupos A, B, D e E, por serem grupos de menor complexidade, ou seja, mais simples as contradições praticamente inexistam (sob o ponto de vista estatístico), ou seja, de tal monta que as suas significâncias se ajustem a estatística proposta (qui-quadrado), não ocorreu o mesmo no grupo $\mathrm{C}$, neste caso, devido à maior 
complexidade as contradições se tornam evidentes e por conseqüência o não ajustamento dos dados daquele grupo a estatística proposta.

Chega-se assim ao desiderato que os documentos médico legais da amostra pesquisada realmente em sua maior parte são insuficientes e inadequados para servirem de prova científica. 


\section{CAPÍtULO IV}

\section{SOBRE O MÉTODO: REFLEXÃO E PROPOSTA}

A Medicina Legal, enquanto Ciência, posição esta referenciada no segundo capítulo desta Tese, manifesta-se por uma metodologia em sua maior freqüência derivada da Medicina, da Biologia (sensu lato), da Física, da Química, das denominadas Ciências Jurídicas, etc. Metodologia no sentido definido por Lalande (1999: 680) como "subdivisão da Lógica, que tem por objeto o estudo a posteriori dos métodos, e mais especialmente, vulgarmente, o dos métodos científicos".

Os autores modernos da Medicina Legal, entre eles, Genival Veloso de França, apontam a figura de Nerio Rojas como aquele que introduziu a discussão do "método", como essencial ao sistema teorético da Medicina Legal. Assim se expressa Nerio Rojas (1936: 1124):

Toda ciencia busca su síntesis en ciertos principios concretos. La ética persigue el mismo fin para dar bases normativas a la conducta. Es a lo que aspira la ciencia moral con los diez mandamientos que Moisés habría recibido de Dios en el Sinaí. Son "diez palabras" de sabiduría, o sea el Decálogo. En un campo menos vasto y guardadas las proporciones, la medicina legal podría también tener el suyo. No ya como normas deontológicas de orden moral para el ejercicio de la professión, sino como normas 
técnicas de orden práctico para la realización de los peritajes forenses. Es lo que intento concretar en estas páginas en forma de diez postulados que puedan servir de guia general a los peritos. Es a lo llamo un decálogo médicolegal.

$1^{\circ}$ - El perito debe actuar con la ciencia del médico, la veracidad del testigo y la ecuanimidad del juez.

$2^{\circ}$ - Es necesario abrir los ojos y cerrar los oídos.

$3^{\circ}$ - La excepción puede ser de tanto valor como la regla.

$4^{\circ}$ - Desconfiar de los signos patognomónicos.

$5^{\circ}$-Hay que seguir el método cartesiano.

$6^{\circ}$ - No fiarse en la memoria.

$7^{\circ}$-Una autopsia no puede rehacerse.

$8^{\circ}$ - Pensar con claridad para escribir con precisión.

$9^{\circ}$ - El arte de las conclusiones consiste en la medida.

$10^{\circ}$ - La ventaja de la medicina legal está en no formar una inteligencia exclusiva y estrechamente especializada.

Onde fundamentar-se inicialmente um "método" próprio da Medicina Legal, capaz de ser referência aos estudiosos desta ciência? Quais autores elaboraram doutrina sobre o Método, no universo da Filosofia e da Ciência, melhor ainda, na Filosofia da Ciência? Para Nerio Rojas, citado acima, uma síntese metódica estaria no seu "decálogo técnico", ou "decálogo científico", que poderia servir de "método" para um agir correto do perito.

\section{A) A justificativa da escolha dos autores}

Partindo do entendimento (no sentido kantiano do termo) de que fazer ciência exige uma base doutrinária sólida, iremos iniciar um périplo na produção intelectual de Aristóteles, Descartes, Kant, Piaget, Popper e Granger, onde eles tratam do Método em suas diversas nuances visões e imagens.

Método (sensu lato) é identificado como caminho, via para a consecução de algo, ou seja, daquilo que se predeterminou tanto sob o ponto de vista da estratégia e da tática, quanto naquelas situações aonde se chegou a um resultado, de forma não premeditada. Ao consultarse o pensamento da antigüidade clássica, por exemplo, em Aristóteles, método se confunde com investigação; em nosso entendimento, com estudo processual definido e seguido pelas estruturas encefálicas (espírito na antiguidade clássica) na busca de um objetivo.

Há que se separar o método enquanto contendo aspectos a priori, pois, nesta situação, encontra-se a capacidade do encéfalo humano de criticar, ordenar, determinar e estabelecer relações tendo, portanto, uma existência "interna" - e assim, o método torna-se inteiramente 
diverso de suas aplicações, daquelas situações que se podem dizer a posteriori quando se busca, por exemplo, refazer o caminho percorrido numa determinada operação.

Essa distinção que fazemos acima justifica os autores que selecionamos para estudo, agora e na questão da Doutrina. Porque apenas o a priori, já vimos, dá lugar ao organismo, ao funcionamento cerebral como determinante do Método que se aplicará aos dados da experiência. Deixamos de lado os empiristas que defendem essencialmente a indução, embora tenham sido suas teorias consideradas na História como fundamentais: Francis Bacon (15611626) o grande codificador do método científico de Galileu em termos empíricos, David Hume (1711-1766), John Stuart Mill (1806-1873) e outros. Assumimos assim, a possibilidade de uma Filosofia da ciência biológica, a partir da Filosofia da ciência física propriamente dita.

\section{B) O Método e a Lógica de Aristóteles}

O Método, em Aristóteles, foi possível para nós percebermos, após estudos e pesquisa na Metafísica do filósofo, na Dialética e nos Segundos Analíticos (sob a ótica de Porchat Pereira), nos Tópicos, Primeiros Analíticos, na Física e por fim nas Refutações Sofísticas (sob a ótica de Enrico Berti), é iniciado no silogismo apodítico, onde a partir de premissas chega-se a coisas diversas daquelas, ou seja, à conclusão. As premissas necessitam ser fundamentadas na aletheia, devem ser imediatas e além do mais, primevas e anteriores à conclusão. Estas premissas assim fundamentadas teriam, no pensar aristotélico, dois caminhos a seguir: seriam definições (thesis) e exprimiriam a substância (principal categoria aristotélica), ou seriam suposições, conjecturas (hypóthesis), ou seja, proposições cujo valor verdade depende da verdade ou falsidade de outra proposição. Pode-se perceber que se chega, por estas reflexões, à dialética aristotélica com certa facilidade.

A proposta de se estabelecer "método" próprio (termo que significa para os estudiosos de Aristóteles: determinação que embora seja um qualificativo de um objeto específico, não podendo ser atribuída a qualquer outra realidade, não participa de sua essência ou definição) para a Medicina Legal, pressupõe também "princípios" próprios, ou seja, aquilo a partir do que se demonstra algo e se individualiza o território de determinada ciência. Aristóteles ainda propõe outros princípios, estes gerais, como o princípio da não-contradição (é impossível afirmar e negar ao mesmo tempo um mesmo predicado de um mesmo sujeito) e o princípio do terceiro excluído (é necessário ou afirmar ou negar certo predicado de certo 
sujeito). Tais princípios não são premissas, não levam necessariamente à conclusão, antes, são princípios gerais ordenadores do pensar humano, ou seja, da Lógica, portanto aplicáveis a qualquer ciência que tenha como corolário a demonstração, caso da Medicina Legal.

A Lógica enquanto sistematização atribuída a Aristóteles se manifesta pela inferência, portanto, dedução, indução, raciocínio, conseqüentemente, para nós processo cerebral, nos remete a uma espécie de Método do pensar humano, é antes de tudo categórica leve-se em conta as categorias do filósofo citadas no capítulo II desta Tese que nos direcionam aos quantificadores "todos" e "alguns", dando origem aos célebres enunciados aristotélicos:

\section{Todos As são B}

Nenhum A é B

Alguns As são B

Alguns As não são B.

Os enunciados acima constituem o denominado quadrado aristotélico, instrumento essencial da Lógica, instrumento este organizado através dos silogismos apodíticos, silogismos estes (como referenciado por diversas vezes nesta Tese), constituídos por uma premissa maior, seguida de uma premissa menor e acabados por uma conclusão. O silogismo apodítico é, portanto, um argumento e faz parte do Método em Aristóteles. A Lógica aristotélica foi por longo tempo, criticada como formadora unicamente de tautologias, não serviria por extensão (no sentido cartesiano do termo), para orientar, justificar ou organizar aquilo que se apresentasse como novidade no pensar humano.

A Lógica clássica, dividida até a Idade Média, entre uma apresentação menor ou formal e uma apresentação maior ou material, por sua visão generalista não se manteve, pois, trabalhos posteriores a Aristóteles que nas obras Categorias, De interpretatione e nos livros do Organon, as havia estabelecido de tal forma que moldaram o pensar ocidental, especialmente o pensar ciência. Foi esta Lógica, sistematizada por Boecio (470-525), Pedro Abelardo (1079- 1142) especialmente na (Lógica para principiantes), Guilherme de Ockham (1295-1350). Porém estes autores não acrescentaram muito ao já firmado pelo Estagirita.

A Lógica de Aristóteles foi ampliada e atrelada à Matemática com os trabalhos de Leibniz (1646-1716), de Boole (1815-1864), e muito especialmente de Frege (1848-1925), e 
Russel (1872-1970), Peano (1858-1932) e diversos outros filósofos e matemáticos poderiam ser citados. Hodiernamente a Lógica de Aristóteles ainda é referência importante para os estudiosos da Lógica, da Filosofia e para os pensadores das ciências, ou seja, os Filósofos da Ciência.

As representações algébricas do silogismo apodítico, aparecem com aqueles filósofos que viram através da matematização do mesmo silogismo, um Método para se fortalecer as proposições categóricas contidas no denominado quadrado aristotélico, propiciando, então, a possibilidade de se entender (no sentido kantiano do termo), o agora silogismo categórico, que subordina a inferência (aqui entendida no sentido da Lógica, portanto, atividade da inteligência, através da qual se afirma o valor verdade de uma proposição em decorrência de sua ligação com outra já considerada como verdadeira) a um rol de itens a serem conferidos, visualizados, entendidos, especialmente, naquelas situações em que se visualiza o fenômeno. Os quais seriam as representações algébricas de tal silogismo categórico:

$$
\begin{aligned}
& \text { Todos As são } B \rightarrow A=A B \\
& \text { Todos Bs são } C \rightarrow B=B C \\
& \text { Todos As são } C \rightarrow A=A C
\end{aligned}
$$

Em Berlinski (2000: 33-34) o silogismo categórico é assim descrito:

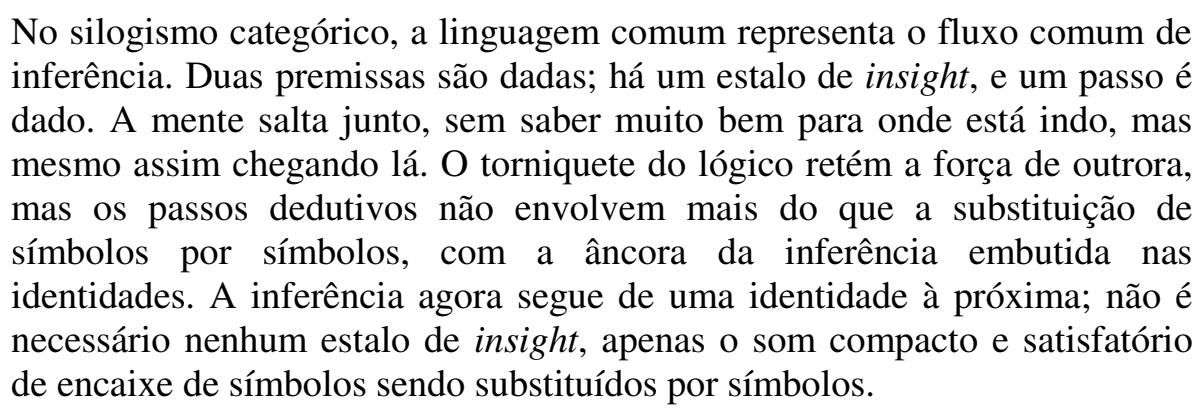

Berti (1998: 8/9) ao comentar o pensamento do Estagirita na análise da Ciência enquanto apodítica e dialética, assim se pronuncia:

O que mais nos interessa, e que Aristóteles não deixa de enfatizar, é que a necessidade de princípios próprios implica uma rigorosa distinção entre as ciências demonstrativas e uma absoluta independência de cada uma em relação às outras. Toda ciência, com efeito, tem necessidade de princípios próprios, que não podem ser inferidos das outras ciências, e não pode, por 
sua vez, demonstrar os princípios próprios das outras ciências; ou melhor, o fato de que os princípios próprios de certa ciência pertençam a ela e só a ela, isto é, que exprimam somente as definições e apreensões dos objetos próprios a ela, implica que nenhuma demonstração possa passar de certo gênero de objetos, próprios de certa ciência, a outro gênero de objetos, próprios de ciência diversa. É interditada, em suma, na demonstração, a passagem a outro gênero. Isso implica a impossibilidade de uma ciência universal, a partir da qual se possam demonstrar os princípios próprios de todas as outras ciências, como também a impossibilidade de uma ciência capaz de demonstrar os princípios comuns a todas as outras, nem os princípios próprios, com efeito, nem os comuns, enquanto princípios são demonstráveis. As ciências demonstrativas são todas, portanto, sempre e somente ciências particulares.

Ao buscarmos um Método próprio para a Medicina Legal, percebemos que somente individualizando tanto a Doutrina quanto o Método da mesma, torna-se possível atribuir-lhe, o caráter e chamá-la de ciência, isto, sob a ótica do Estagirita.

A visão aristotélica de mundo, ou o modo do Estagirita perscrutar, perceber, avaliar e refletir sobre a experiência e o fenômeno, ou ainda, o modo peculiar do filósofo conhecer e fazer ciência, além do silogismo apodítico ou demonstrativo, é vivenciado por ele na Dialética. Enquanto no silogismo apodítico se encontra um caminho determinado em uma direção, aonde das premissas chega-se à conclusão, demonstrando-se uma a uma as idéias, numa atividade que sugere o ensino; na dialética, estabelece-se não um monólogo, mas sim um diálogo (certamente inspirado em Platão), uma conversa entre uma proposição e sua oponente, até se chegar a outra proposição diversa das anteriores. Aristóteles propõe um "método" de investigação que deve servir ao pensar, partindo de opiniões contrárias e não se permitindo entre elas a posição intermediária. A dialética aristotélica prima pela universalidade (ao contrário da particularidade da ciência apodítica) mantém o mesmo destino formal da lógica, serve à primeira Ciência, ou seja, à Filosofia.

Porchat Pereira (2001: 355/356) ao tratar sobre Os Tópicos e a Dialética da obra aristotélica, assim se pronuncia:

Deixemos, por um momento, de lado, a problemática da aquisição dos princípios, tal como ela se coloca no último capítulo dos Analíticos e consideremos, porque a ela também se refere, uma passagem dos Tópicos de Aristóteles, cuja contribuição para a solução das dificuldades com que nos defrontamos haverá de revelar-se decisiva. No início daquele tratado, com efeito, após definir como seu propósito a descoberta de um método que nos permita raciocinar sobre todo problema proposto a partir de premissas aceitas, assim como defender nossas opiniões sem incidir em contradição, o 
filósofo, tendo distinguido as várias espécies de silogismo e definido o silogismo dialético, objeto principal de sua investigação, continua: 'Em seguida ao que foi dito, deve dizer-se para quantas e quais coisas é útil este tratado. Ele o é para três coisas: para o exercício, para os encontros casuais, para as ciências filosóficas. Que é útil para exercício é manifesto a partir do que já foi dito; com efeito, possuindo um método, poderemos mais facilmente argumentar sobre o problema proposto. Para os encontros casuais, porque, tendo inventariado as opiniões da maioria dos homens, por-nosemos em relação com eles, apoiados, não em pontos de vista que lhes são estranhos, mas nos seus próprios, fazendo mudar o que não nos pareçam dizer corretamente. Para as ciências filosóficas, porque, sendo capazes de percorrer as aporias em ambos os sentidos, perceberemos mais facilmente, em cada caso, o verdadeiro e o falso; também no que concernem as primeiras dentre as proposições que respeitam a cada ciência. De fato, é impossível, a partir dos princípios apropriados à ciência em questão, dizer algo sobre eles mesmos, uma vez que os princípios são primeiros dentre todas as proposições; mas é por meio das proposições aceitas a respeito de cada ponto que é necessário discorrer sobre eles. Ora, esta é a tarefa própria, ou mais apropriada, à dialética, pois, de natureza perquiridora, ela possui o caminho que leva aos princípios de todas as doutrinas científicas'.

Prossegue Porchat Pereira (2001), nas mesmas páginas, confirmando o acima referenciado sobre a universalidade da dialética: "Diremos, então, que a dialética ocupando o mesmo domínio universal e comum que é o da filosofia primeira, é prova e exame no que respeita àquelas mesmas coisas que a filosofia conhece e que a sofística, sabedoria meramente aparente, tão-somente aparenta conhecer, mas de fato desconhece".

A causalidade em Aristóteles é estabelecida sob quatro caminhos, ou seja, material, formal, motora e final. Por qualquer destes "caminhos" se pode fazer ciência, no entanto, sob o aspecto formal, que também se chama quididade (virtude essencial) define-se o que certa coisa ou algo é o que é. Para o filósofo, fica determinado que, para se ter ciência de algo, é necessária a demonstração das propriedades do mesmo, a partir dos princípios próprios a ele concernentes e ainda a apreensão de sua existência e a definição de sua essência (quididade). (Isso seria válido para toda e qualquer ciência, em especial a matemática, que utiliza sobremaneira a quididade, enquanto as demais ciências usariam as outras causas, ou seja, a causa material, a motora e a final).

Portanto, sendo o conceito determinado a partir das sensações e por consequiência do fenômeno percebido e apercebido através daquelas, que temos no primeiro âmbito sob o qual se podem examinar as diversas formas da racionalidade pensadas, teorizadas por Aristóteles, ou seja, a Física, onde para o filósofo o pensar ciência, ou seja, a racionalidade apodítica ou 
demonstrativa se torna viva por um estatuto onde a demonstração dos atributos de determinado objeto ou coisa, ou seja, a apreensão da sua existência e a definição da sua essência seja valida para todas as ciências.

O referido acima parece levar à implicação (no sentido advindo da Lógica: relação estabelecida entre dois conceitos ou proposições, de tal forma, que a veracidade atribuída a um deles, conduza necessariamente a veracidade do outro) de que o conhecimento dos princípios próprios, que Aristóteles entende existir através de uma "faculdade", anterior à ciência propriamente dita, isto é, a inteligência (intellectus) que processa o percebido e apercebido através da experiência, complica-se mais nas ciências físicas que nas matemáticas. Podemos perceber que nestas não parece haver muita dificuldade, por exemplo, em entender uma sequiência numérica, a definição de ponto, linha, triângulo, ou ainda a definição de número primo, dos axiomas aritméticos estabelecidos por Peano, (0 é um número; $\mathrm{O}$ sucessor de qualquer número é um número; Se $a$ e $b$ são números, e se seus sucessores são iguais, então $a$ e $b$ são iguais; 0 não é sucessor de qualquer número; Se $\mathrm{S}$ é um conjunto de números que contém 0 , e se o sucessor de qualquer número $n$ de $S$ está também contido em $S$, então $S$ contém todos os números), pelo contrário, seria muito mais complexo encontrar-se a quididade nos fenômenos atômicos, subatômicos, biológicos, cujos atributos ou substâncias são muito mais complexos.

Se olharmos os eventos estudados pela Medicina Legal, veremos que aí, além da complexidade inerente às ciências físicas, aliam-se os fatores biológicos, sociais e aqueles da legislação, que complicam sobremaneira o entendimento dos mesmos, de onde advém a necessidade do uso de todos os tipos de causas (formal, material, motora e final) no entendimento destas ciências, e por extensão, à Medicina Legal.

Para Aristóteles, no livro VI da Metafísica (1025: 5-30), a ciência que deixa lúcida a essência de seu objeto através da sensação é a física, e aquela que a apresenta como hipótese é a matemática, sendo que esta demonstra através do necessário e aquela através do freqüente e em ambas jamais pelo acidente, onde não se faz ciência. Veja-se o que profere o filósofo às páginas citadas:

Principia et causae quaeruntur entium: palam autem quia inquantum entia. Est enim aliqua causa sanitatis et convalescentiae. Sunt et mathematicorum principia et elementa et causae, et totaliter omnis scientia intellectualis 
participans aliquid intellectus circa causas et principia est aut certiora, aut simpliciora. Sed mones illae circa unum quid et genus aliquod circumscriptae, de hoc tractant; sed non de ente simpliciter,Nec inquantum est ens. Nec de ipso quod quid est ullam faciunt mentionem. Sed ex hoc alliae quidem sensu facientes ipsum manifestum, aliae per suppositionem accipientes quod quid est, sic secundum se quae insunt generi circa quod sunt, demonstrant, aut magis necessarie, aut infirmius. Quapropter palam quia non est demonstratio substantiae, Nec eius quod quid est ex tali inductione, sed alius modus est ostensionis. Similiter autem Nec si esta ut non est genus circa quod versantur, nihil dicunt eiusdem scientiae ipsum quid est manifestum facere, et hoc si est. Quoniam vero physica scientia est circa genus quoddam entis, nam circa talem est substantiam in qua est principium motus et quietis in ea, palam quia $\mathrm{Nec}$ activa $\mathrm{Nec}$ factiva est. Factivarum enim, in faciente principium, aut intellectus, aut ars, aut potentia quaedam. Activarum vero in agente prohaeresis. Idem enim agibile et elegibile. Quare, si omnis scientis aut activa, aut factiva, aut theorica, physica theorica quaedam est. Sed theorica circa tale ens quod est possibile moveri; et circa substantiam quae est secundum rationem, ut secundum magis non separabilem solum. Oportet autem quod quid erat esse, et ratioenm quomodo est, non latere, qui sine hoc quaetere nihil est facere. Definitorum autem et ipsorum quid est, haecnquidem ita sunt ut simum, illa vero ut concavum. Differunt autem ea, quia simum conceptum est cum materia; est enim simus nasus concavus, concavitas vero sine materia sensibili.

Na tradução de Yebra: Buscamos los principios y las causas de los entes, pero es claro que en cuanto entes. Hay, en efecto, una causa de la salud y del bienestar, y de las Cosas matemáticas hay principios y elementos y causas, y, en suma, toda ciencia basada en la razon o que participa en algo del razonamiento versa sobre causas y principios, ora más rigurosos ora más simples. Pero todas estas ciencias, habiendo circunscrito algún ente y algún gênero, tratan acerca de el, y no acerca del Ente en general ni en cuanto ente, ni se procupan para nada de la quididad, sino que, partiendo de ésta, unas después de ponerla de manifiesto para la sensación y otras tomando la quididad como hipótesis, demuestran así, con más rigor, las propriedades inherentes al gênero de que se ocupan. Por eso es evidente que no hay demonstración de la substancia ni de la quididad a base de tal indución, sino que es otro el modo de su manifestación. De igual manera, tampoco dicen nada acerca de si existe o no existe el género de que tratan, por ser propio de la misma operación del entendimiento mostrar la quididad y su existencia. Y, puesto que también la Fisica es una ciencia que versa sobre cierto género del Ente (pues trata de aquella substancia que tiene en si misma el principio del movimiento y del reposo), es evidente que ni es práctica ni factiva (las cosas factibles, en efecto, tienen en el que las hace su principio, que es la mente, $o$ algún arte o potencia, y las practicables lo tienen en el que las practica, y es el propósito; pues lo practicable y lo propuesto son lo mismo); de suerte que, si toda operación del entendimiento es práctica o factiva o especulativa, la Fisica será una ciencia especulativa, pero especulativa acerca de un ente tal que sea capaz de moverse, y acerca de la substancia, ségun el enunciado generalmente, pero no separable. $\mathrm{Y}$ es preciso que no desconozcamos cómo es la esencia y el enunciado, pues sin esto de nada servirá la indagación. Pues bien, de las cosas que se definen y de las quididades, unas son como lo chato, y otras, como lo côncavo. Y se diferencian en que lo chato se toma 
junto con la materia (pues lo chato es una nariz côncava), mientras que la concavidad es independiente de la materia sensible.

Foi visto em capítulo anterior, onde se trata da Doutrina, sob o olhar de Porchat Pereira, e consubstanciado no texto acima, que Aristóteles, nos Segundos Analíticos e na Metafísica, estabelece que a ciência demonstrativa contida nas matemáticas e também na física, cuida do universal e do necessário, tendo como fundamento a causalidade. Porém, o filósofo, aborda, na mesma obra, algo mais flexível, ou seja, o freqüente, onde também se faz ciência. Tal flexibilidade no ler a experiência, captada pelas sensações, não nega o necessário, este, caráter essencial da ciência apodítica, antes, o reafirma, embora nas ciências físicas o freqüente constitua o que ocorre mais freqüentemente e isto distancie as matemáticas das ciências físicas, pois naquelas os fundamentos são sempre o universal e o necessário, nestas, o que ocorre no "mais das vezes", ou seja, o freqüente parece enfraquecer o rigor científico. No entanto, é bom levar-se em consideração que a "flexibilidade" contida nas ciências físicas não é um grau menor da necessidade, pois o "necessário" não tem gradação, embora comporte as diferenças, ou seja, uma racionalidade diversa, advinda do valor cognitivo de cada uma das denominadas "ciências físicas", especialmente as "biologias", pois a natureza dos seus "objetos de conhecimento" lhes permite maior aditividade do predicado ao sujeito, facultando, assim, um melhor conhecimento. É bom que fique ressaltada a "causa formal", representada pela quididade como fundamento das matemáticas, enquanto as outras causas, ou seja, a causa material, a motora e a final em consonância com a causa formal, buscam explicar a complexidade crescente das denominadas "ciências físicas" no olhar aristotélico. É preciso que se diga, ainda que rapidamente, que estamos cientes das modificações e da real "mudança de paradigma" no entender de Granger, que ocorreram com o nascimento da Física moderna com Galileu. No entanto, como aqui fazemos abstração do que se refere ao método, achamos adequado falar ainda das concepções aristotélicas sobre a sua Física, inclusive porque aquilo que foi dito por ele em sua época sobre a Filosofia da Física, seria de certo modo válido hoje em dia, para uma Filosofia da Biologia.

Aristóteles, embora seja o pai oficial do empirismo, (antes dele em termos muitíssimo mais modestos existiu a filosofia de Heráclito de Éfeso) criou sua teoria em função do pensar corretamente e, sua Lógica, sabe-se, prescrevia as regras desse pensar. Assim, nesse sentido, a teoria aristotélica também é compatível com a neurociência e com a Filosofia da Biologia. 
No livro II da Metafísica, Aristóteles busca definir com clareza o que seria o Método nas ciências físicas e ainda em uma parte obscura de sua obra, que de forma indistinta fica entre a Física e a Metafísica, deixando um legado essencial ao estudo de uma "leitura da experiência", leitura esta sob o olhar piagetiano, da sua obra. Veja-se o que nos diz o filósofo (993: 5-25)

\begin{abstract}
De veritate theoria sic quidem difficilis est, sic vero facilis. Signum autem, $\mathrm{Nec}$ digne nullum adipisci ipsam posse, $\mathrm{Nec}$ omnes fallere, sed unumquemque aliquid de natura dicere. Et secundum unumquemque quidem nihil aut parum ei immittere, ex omnibus autem coarticulatis fieri magnitudinem aliquam. Quare, si videtur habere ut proverbialiter dicimus, In foribus quis delinquet? sic quidem utique erit facilis. Habere autem totum et partem non posse, difficultatem eius ostendit. Forsan autem et difficultate secundum duos existente modos, non in rebus, sed in nobis est eius causa. Sicut enim nycticoracum oculi ad lucem diei se habent, sic et animae nostrae intellectus ad ea quae sunt omnium natura manifestíssima. Non solum autem his habere gratiam iustum est, quorum aliquis opinionibus communicaverit; sed his qui adhuc superficialiter enuntiaverunt. Etenim conferunt aliquid. Nam habitum nostrum praeexercuerunt.

Na tradução de Yebra: La investigación de la verdad es, en un sentido, difícil; pero, en outro, fácil. Lo prueba el hecho de que nadie puede alcanzarla dignamente, ni yerra por completo, sino que cada uno dice algo acerca de la naturaleza; individualmente, no es nada, o es poco, lo que contribuye a ella; pero que todos reunidos se forma una magnitud apreciable. De suerte que, si verdaderamente la situación es aquí similar a la que solemos expresar por un proverbio, "quién puede no dar en una puerta?". En este sentido, la investigación de la verdad sin duda es facil; pero el hecho de alcanzar el todo y no poder alcanzar una parte muestra su dificultad. Quizá también, siendo la dificultad de dos clases, su causa no está en las cosas, sino en nosotros. Pues el estado de los ojos de los murciélagos ante la luz del dia es también el del entendimiento de nuestra alma frente a las cosas más claras por naturaleza. Y es justo que estemos agradecidos no solo a aquellos cuyas opiniones podemos compartir, sino también a los que se han expresado más superficialmente. Pues también éstos contribuyeron con algo, ya que desarrollaran nuestra facultad de pensar.
\end{abstract}

$\mathrm{Na}$ ambiência do agir pericial, ou seja, na prática cotidiana do médico-legista, as dificuldades encontradas pelos peritos diante de um evento ou fenômeno, especialmente ao constituir as seqüências lógicas graças aos processos mentais, quando diante da obrigação de estabelecer as "causas", buscar o entendimento do evento e a seguir reportá-lo em documento específico, para servir de "prova" em determinado processo legal, passa pela dificuldade de encontrar a verdade objetiva, ou seja, aquela que independe da interpretação e é impessoal, ou ainda quando busca a certeza (no ambiente médico-legal: afirmação positiva sem o receio do erro), são incontestes aquelas dificuldades. 
O mesmo "método" serviria às ciências matemáticas e às ciências físicas na ótica aristotélica? O mesmo rigor científico atenderia tanto àquelas, quanto a estas ciências? Em nosso entendimento, não, devido à materialidade das ciências físicas, ou ciências da Natureza, pois enquanto as ciências matemáticas se colocam no necessário e no universal, as ciências físicas contemplam também a lógica das classes e o freqüente, ou seja, o que ocorre no mais das vezes e devido à presença material, provoca, exige, outro método. Veja-se o que prolata o filósofo na Metafísica (995a: 5-20):

Contingunt autem auditiones secundum consuetudines entibus. Nam ut consuevimus ita dignamur dici: et quae praeter ea, non similia videntur, sed propter inconsuetudinem minus nota et magis extranea. Nam consuetum notius. Quantam vero vim habeat quod consuetum est, leges ostendunt, in quibus fabularia et puerilia magis valent cognitione de eis propter consuetudinem. Alli vero, si non mathematice quis dicat, non recipiunt dicentes. Alli vero si non exemplariter. Et hi testem induci dignantur poëtam. Et illi quidem omnia certe. His vero flebilis est certitudo aut propter impotentiam complectendi, aut propter micrologiam: habet autem quod certum est tale. Unde, quemadmodum in symbolis, et in rationibus non liberum esse quibusdam videtur. Propter quod oportet erudiri quomodo singula sunt recipienda, ut absurdum simul quaerere scientiam et modum sciendi. Est autem neutrum facile accipere. Acribologia vero mathematica non in omnibus est expetenda, sed in non habentibus materiam. Propter quod non naturalis est modus: omnis enim forsan natura materiam habet. Ideo primum perscrutandum quid est natura. Ita namque et de quibus est physica,manifestum erit. Et si unius scientiae aut plurium est causas et principia considerare.

Na tradução de Yebra: El resultado de las lecciones depende de las costumbres de los oyentes. En efecto, queremos que se hable como estamos acostumbrados a oír hablar, y las cosas dichas de outro modo no nos parecen lo mismo, sino, por falta de costumbre, más desconocidas y extrañas. Lo acostumbrado, en efecto, es fácilmente conocible. Y cuánta fuerza tiene lo acostumbrado, lo mostran las leyes, en las cuales lo fabuloso y lo pueril, a causa de la costumbre, pueden más que el conocimiento acerca de ellas. Unos, en efecto, no escucham a los que hablan si no se habla matemáticamente; otros, si no es mediante ejemplos; éstos exigen que se aduzca el testimonio de algún poeta; aquellos todo lo quieren con exctitud, y a los de más allá les molesta lo exacto, o por no poder seguir el razonamiento o por la enumeración de pequeñeces. El prurito de exactitud tiene, en efecto, algo de esto; de suerte que, como los tratos, también en los razonamientos les parece a algunos impropio de hombres libres. Por eso es preciso aprender previamente cómo podrá ser comprendidda cada cosa, pues es absurdo buscar al mismo tiempo la ciencia y el modo de la ciencia. Y ninguno de los objetivos es fácil de alcanzar. La exactitud matemática del lenguaje no debe ser exigida en todo, sino tan solo en las cosas que no tienen matéria. Por eso el método matemático no es apto para la Física; pues toda la Naturaleza tiene probablemente matéria. Por conseguiente, hay que investigar primero cosas trata la Física [y si corresponde a una ciencia o a varias estudiar las causas y los principios]. 
O uso da Dialética, como método das ciências físicas (modernamente: "ciências da natureza”), já é visto por Aristóteles como próprio destas ciências que devem por excelência (arethé) definir ab initio os princípios, estes, fundamento do pensar as ciências. Através da dialética, o filósofo propõe que se percorra uma via que vai dos objetos mais conhecidos para o pesquisador àqueles mais adequados, por natureza. Por conseqüência, ir-se-ia através das sensações à experiência, daí, chegando-se necessariamente aos princípios, e em se chegando aos princípios tende-se naturalmente à visão dos objetos compostos, portanto, à visão do conjunto, do todo, que é mais bem percebido através da experiência, fechando-se este ciclo dialético quando Aristóteles diz que: "os princípios dividem as realidades compostas". Haveria aqui uma "via do conhecimento de cunho indutivo" para se chegar ao "universal" e ao "necessário"? Ou estar-se-ia diante de uma aporia (enquanto "dificuldade lógica")? Atendendo-se à ótica aristotélica, se está de frente para o fundamento do pensar ciência e conhecimento, ou seja, "o conhecimento se inicia na experiência". Esta via é com certeza muito complexa e processual, portanto, nada tem de "imediata". Contudo Kant e Piaget virão a acreditar nesta idéia de que o conhecimento começa na experiência, porém, para ambos, dela não derivará, porque a leitura dessa experiência, repitamos, depende do Entendimento Puro (Kant) e do funcionamento endógeno, orgânico, das estruturas mentais (Piaget).

O Método das ciências físicas sob a ótica do filósofo grego seria, no entanto, o proporse aporias (mostrar-se as dificuldades lógicas) e solucioná-las elaborando-se suas conseqüências.

Aristóteles na Metafísica (Livro III - 995: 20-25) assim se refere sobre o método especulativo no investigar-se a experiência.

Et utrum circa substantias solum speculatio, aut circa quae accidunt secundum se substantiis. Adhuc de eodem et diverso, simili et dissimili et contrarietate, priore et posteriore et aliis omnibus talibus de quibus dialectici intendere tentant, ex probabilibus solum perscrutationem facientes, cuius est theorica de omnibus.

Na tradução de Yebra: Es preciso, como decimos, examinar las dificultades, y también la de si nuestro estudio es solo sobre las substancias o también sobre los accidentes propios de las substancias. Y, además, sobre lo Mismo y lo Otro, lo Semejante y lo Desemejante, y la Contrariedad, sobre lo Anterior y lo Posterior y todas las demás nociones parecidas, acerca de las cuales tratan de indagar los dialécticos, basando su indagación en meras opiniones, a qué ciência corresponde especular sobre todas estas cosas. 
Pode-se perceber no texto acima que o filósofo delineia o processo de solução das aporias: após validar-se uma das hipóteses, ou seja, remover-se a sua oponente, ou melhor, ainda, delinear-se a aletheia em oposição ao pseudo, Aristóteles faz a devida demonstração da dialética, estabelecendo assim, a possibilidade de se fazer ciência com aquela metodologia, ou seja, a dialética; não se escapando de uma apofântica (termo definido por Aristóteles para definir entre os enunciados aqueles que podem conter ou não a aletheia).

O uso de a metodologia Dialética no fazer, no pesquisar e no conhecer as ciências, especialmente, as ciências físicas, ou ciências da natureza, na ótica do Estagirita, nos remeterá ao pensar cartesiano, kantiano e piagetiano.

\section{C) O Método em Descartes. As regras para a direção do espírito}

Foi Descartes, o filósofo que imortalizou as reflexões sobre o "Método", especialmente no célebre Discurso do Método, publicado pela primeira vez em 1637, em Leiden na França. Obra esta, que trazia ainda outros trabalhos: A Dioptria, Os Meteoros e A Geometria; onde estabelece o primado da Razão humana, em substituição ao primado da autoridade eclesiástica de então. Nos outros trabalhos, Descartes tratava dos seus estudos sobre a Ótica, sobre Astronomia e fundava a Geometria Analítica.

Nerio Rojas (1936), já citado, preconiza o uso do método cartesiano, para o bem agir do médico-legista; e torna-se necessário perscrutar-se o que nos diz Descartes, sobre como bem conduzir a observação do fenômeno e o conseqüente entendimento do mesmo.

Descartes (2003: 31-32), ao explicar o como pensar adequadamente nos ensina que se deve seguir um determinado Método na busca da verdade, qual seria este caminho ver-se-á a seguir:

O primeiro consistia em nunca aceitar como verdadeira nenhuma coisa que eu não conhecesse evidentemente como tal, isto é, em evitar, com todo o cuidado, a precipitação e a prevenção, só incluindo nos meus juízos o que se apresentasse de modo tão claro e distinto ao meu espírito, que eu não tivesse ocasião alguma para dele duvidar.

O segundo, em dividir cada uma das dificuldades que devesse examinar em tantas partes quanto possível e necessário para resolvê-las.

$\mathrm{O}$ terceiro, em conduzir por ordem os meus pensamentos, iniciando pelos objetos mais simples e mais fáceis de conhecer, para chegar, aos poucos, 
gradativamente, ao conhecimento dos mais compostos, e supondo também, naturalmente, uma ordem de precedência de uns em relação aos outros.

E o quarto, em fazer, para cada caso, enumerações tão completas e revisões tão gerais, que eu tivesse a certeza de não ter omitido nada.

Vimos, em texto acima, que Aristóteles já falava das dificuldades em mudarem-se os costumes, e especialmente aqueles hábitos, inclusive do pensar aos quais estamos acostumados. Também podemos nos reportar aos textos de Descartes contidos no capítulo sobre a Doutrina nesta Tese, em que ele fala das causas essenciais dos nossos erros, erros estes que se iniciam na infância e a partir dela se perpetuam, de tal forma, que, tanto na ótica aristotélica, quanto na ótica cartesiana fica demonstrada a força do costume, perante o conhecimento adquirido.

Para Descartes na Meditação Primeira, onde o filósofo trata das coisas que se podem colocar em dúvida, dúvida esta que não pode ser confundida com aquela do senso comum, porém a dúvida metódica, Descartes (2005: 29) nos diz:

Há algum tempo que me apercebi de que, desde meus primeiros anos, recebera grande quantidade de falsas opiniões como verdadeiras e que o que depois fundei sobre princípios tão mal assegurados só podia ser muito duvidoso e incerto; de forma que me era preciso empreender seriamente, uma vez em minha vida, desfazer-me de todas as opiniões que até então aceitara em minha crença e começar tudo de novo desde os fundamentos, se quisesse estabelecer algo firme e constante nas ciências.

O médico-legista pelo menos algumas vezes, no seu dia a dia, centrado no produzir a prova pericial, acostumado a pensar de acordo com o seu intelecto formado na infância, resistindo ao conhecimento introduzido nos cursos que freqüentou em sua formação, quando tais conhecimentos colidem com os costumes anteriormente adquiridos no pensar, perceber, aperceber e perscrutar o mundo, é instado a perceber o fenômeno através de uma "leitura" que lhe é própria, a entendê-lo, e subseqüentemente reportá-lo em documento hábil, a partir da apreciação e verificação do mesmo fenômeno sob os hábitos e costumes previamente adquiridos. Deveria, no entanto, seguindo as advertências de diversos autores seguir o que se denomina de método cartesiano, que ora passaremos a referenciar.

Antes de adentrarmos no Método cartesiano, perscrutemos a prova, a dificuldade em elaborá-la, os fundamentos da mesma, na ambiência da Medicina Legal de hoje. Para Genival Veloso de França (2008) no capítulo onde trata da Perícia, dos Peritos e da Prova em 
Medicina Legal, o autor estabelece algumas proposições e inferências que abordaremos, pois, ali está tratado um rol de entendimentos sobre a prova.

Quanto ao valor da prova, se a dúvida está presente a prova não foi realizada. O que se estaria buscando no agir pericial, tendo como fulcro o valor da prova? Um conceito, um caminho a percorrer, um objetivo? Se o cerne, das questões aludidas, portanto, o conceito, o caminho, o objetivo, é o que se propõe como diretivas do bem agir na perícia tem que se dar relevância aos elementos demonstrativos deste agir. Demonstrar através dos elementos da Lógica acima referida, ou seja, pelo silogismo apodítico, gerar-se inclusive tautologias, pois interessa ao agir pericial estabelecer a verdade enquanto Aletheia e Veritas, fundamentado no Método Científico. Gerando, conseqüentemente, procedimento que tem por objetivo, enquanto, prova pericial orientar e formar o entendimento do julgador, se em processo cível, elucidar os "fatos controversos", se no processo crime, "todos os fatos".

$\mathrm{Na}$ ambiência da Medicina Legal o objeto da prova seriam os fatos que no interesse da Justiça, cobram, exigem, reclamam uma comprovação, o que culmina, portanto, mais uma vez, em um processo demonstrativo, fundado nos mecanismos da Lógica, enquanto instrumento do pensar (logo processos cerebrais), silogismos apodíticos e como não, também os silogismos categóricos, aludidos acima.

Se o objeto da prova seriam fatos que devem ser comprovados, e que sejam do interesse da Justiça, os sujeitos da prova seriam: a- pessoa, b- coisa, c- fenômeno onde se pode buscar investigar e encontrar a prova.

A parte formal da prova é vivenciada no agir pericial, dentro daquilo que se pode chamar de "percepção material", ou no sentido kantiano do termo, se estaria diante de um "Entendimento"; "Entendimento" este constituído por juízos sintéticos a priori, que embora originado na experiência, têm o elemento a priori oriundo da Razão. Esse "Entendimento" é também constituído de juízos apenas sintéticos (não necessários) que se alternariam, como diz Piaget, com os "sintéticos a priori”, esses sim, necessários.

Sob a ótica da Justiça, enquanto, "maior bem da sociedade" na opinião de Rawls, ou melhor, ainda, sob a perspectiva do Direito, a prova se apresenta na versão oficial quando foi fundamentada e elaborada seguindo-se o rigor legal do Direito Processual e ainda do rigor ético no pesquisar os dados, relacioná-los, comprová-los e assim ir-se dos vestígios aos 
indícios e destes a ela, prova. A outra versão da prova é a denominada "inoficial", que tem tal identidade devido ao não seguimento do Código Processual e/ou a não eticidade no agir investigativo, gerando-se por conseqüência graves distorções que podem invalidar a prova e tornar improvável a lide. No trato dos processos não oficiais que originam elementos probatórios, como o referido à prova inoficial, estar-se-ia diante também da denominada prova proibida, que ao se apresentar como violação das normas efetivas, é ilícita, e ao se apresentar como violação das normas processuais é ilegítima.

Percorrendo o tema prova na vivência médico-legal dos dias atuais (em analogia ao que nos diz Garcia Morente, quando fala da vivência da filosofia), chega-se, sob o olhar de França (2008: 13), ao que o autor denominou de: “avaliação da prova”, que se verá a seguir:

A avaliação da prova pode ser feita por três sistemas conhecidos: 1- Sistema legal ou tarifado - em que o juiz limita-se a comprovar o resultado das provas e cada prova tem um valor certo e preestabelecido; 2- Sistema da livre convicção - em que o magistrado é soberano, julga segundo sua consciência e não está obrigado a explicar as razões de sua decisão; 3Sistema da persuasão racional - quando o juiz forma seu próprio convencimento baseado em razões justificadas. Este último é o sistema adotado entre nós. Nele, mesmo que o juiz não esteja adstrito às provas existentes nos autos, terá que fundamentar sua rejeição. A sentença terá que discutir as provas ou indicar onde se encontram os fatos do convencimento do juiz. Não se pode confundir convicção íntima com livre convencimento do juiz na apreciação das provas.

Perceber-se então que o tema prova, no âmbito da Medicina Legal, está intrinsecamente ligado à necessidade da demonstração, bem no sentido aristotélico, ou seja, ao caráter apodítico do agir e do relatar que, desta forma, se torna cogente. Daí o que escreve Juliano S. A. Maranhão (2008): “a lógica dedutiva é inevitável no raciocínio jurídico”, à página 105 e mais adiante à página 106:

(...) Pode-se até admitir que a decisão jurídica ou o convencimento seja de fato alcançado por um processo emocional ou ideológico, mas, de qualquer forma, a mesma deve se apresentar como fundamentada em premissas normativas para que se lhe garanta racionalidade.

Descartes, ainda no Discurso do Método (2003: 21), inicia os seus estudos e reflexões, falando do "bom senso" no julgar, avaliar e chegar à conclusão, que ora segue:

O bom senso é das coisas do mundo, a mais bem dividida, pois cada qual julga estar tão bem dotado dele, que mesmo os mais difíceis de contentar-se em outras coisas não costumam desejar tê-lo mais do que já têm. E não é 
verossímil que todos se enganem a esse respeito; pelo contrário, isso evidencia que o poder de bem julgar e distinguir o verdadeiro do falso, isto é, o que se denomina o bom senso ou a razão, é naturalmente igual em todos os homens. A diversidade das nossas opiniões não provém do fato de uns serem mais racionais do que outros, mas tão somente em razão de conduzirmos o nosso pensamento por diferentes caminhos e não considerarmos as mesmas coisas.

O Método, para Descartes, foi constituído como "Regras para a direção do espírito", é fundamentado na concepção idealista do mundo, portanto, em oposição ao realismo amplamente predominante de então. Garcia Morente (1980: 167-168) ao comentar o que ele denominou de: dificuldade do idealismo face à facilidade do realismo, assim nos ensina:

A atitude realista que vimos suceder-se aqui, desde os valores do pensamento filosófico até o século XVI, é uma atitude natural, é a que naturalmente toma o homem. Quando o homem começa a dar-se conta de sua existência no universo, naturalmente adota a atitude de supor que o que existe são estas coisas que vê e toca, e que ele está provido de uma faculdade (a inteligência, o pensamento) capaz de receber dessas coisas, impressões variadas e elaborar essas impressões e obter idéias daquilo que são as coisas que aí existem. Essa é a atitude natural. Em troca, o idealismo constitui uma atitude artificial, uma atitude adquirida, não já obtida, desde logo, por nós ao vir ao mundo. Necessitamos tomar esta atitude. Não a temos, mas a tomamos, e a tomamos por uma necessidade histórica.

A ótica idealista, eminentemente cartesiana, contempla principalmente o pensar humano (a inteligência "intellectus", o pensamento), estabelece assim, a diferença entre o pensar o objeto e o fenômeno ou acontecimento de forma imediata, (eu pensando, simplesmente, como na fantasia) e o objeto e o fenômeno ou acontecimento enquanto objeto do pensamento, de forma mediata. Aqui se impõe a mediação, pois, o objeto pensado situa-se mais distante (enquanto processo cerebral) do simples pensar algo, trata-se aqui de uma reflexão enquanto processo.

Garcia Morente (1980: 168- 169) assim comenta a diversidade instalada na díade realismo/idealismo:

O idealismo, longe de ser natural, é uma retificação da atitude natural; retificação que se leva a efeito como conseqüência de necessidades que, de repente, se apresentam. (...) Mas não é somente a contraposição entre natural e artificial; ainda há mais. A atitude do realista, além de natural é espontânea. Não necessita esforçar-se, não necessita um ato deliberado para adotar a que ele tem. Tem-na sem querer. Todo mundo é realista sem querer. A mudança, a atitude idealista é voluntária: há de se querer tomá-la. Se não 
se quer tomá-la, se não se faz esforço para adotá-la, não se adota. (...) $\mathrm{O}$ realismo é uma atitude que poderíamos chamar de extrovertida. Consiste em abrir-se às coisas, em ir a elas, em derramar-se sobre elas, em derramar sobre elas a capacidade perceptiva do espírito. Pelo contrário, o idealismo é uma atitude introvertida; uma atitude que consiste em virar a direção da atenção e do olhar e, em lugar de pousá-los sobre as coisas do mundo que nos rodeia fazer um giro de conversão e recair sobre o próprio eu.

O método cartesiano contempla certo geometrismo no pensar, pois na Geometria e na Matemática o filósofo encontra o meio, o caminho onde repousar a sua crítica da realidade então vivida. Para Garcia Morente (1980: 176), Descartes teria conseguido tirar o eu do mundo. Num mundo cheio de arestas, irregularidades, cores, complicações, ele contrapõe outro, composto por: pontos, linhas, ângulos, triângulos, retângulos, poliedros, esferas, aliados todos estes, a complexos movimentos, é a própria extensão, a extensão das distâncias, possível de existir, desde que fundados nas três substâncias: a substância pensante (o eu pensante ou o pensamento), a extensão (substância extensa ou objeto do conhecimento) e Deus, este a substância criadora, as outras as substâncias criadas. Da interpretação deste mundo assim ordenado em figuras geométricas advém a Geometria Analítica criada pelo filósofo.

A resposta cartesiana ao mundo aristotélico-tomista de então, quando se tem como fulcro o método, é definida por Descartes em quatro regras já referenciadas acima, e que tem algumas palavras que são chaves do pensar do filósofo sobre o tema. As palavras ou conceitos seriam: idéias claras e distintas, atitude analítica, ordenamento das idéias, enumeração (especificação). O filósofo rejeita $a b$ initio o que ele denomina de "idéias obscuras e confusas", a respeito das coisas, dos fenômenos; e a partir de juízos que perscrutam, avalia in extremis, o objeto, a coisa, o algo a ser conhecido e assim acredita, criaria condições para a aceitação racional do mundo. As dificuldades inerentes ao reconhecer o mundo, enquanto expressão da realidade, no conhecer o fenômeno, no entender o algo a ser conhecido, foram resolvidas pelo filósofo, quando ele propõe uma vivência analítica, que adentra ao fenômeno, até que, conhecendo-o, tornam-se possíveis soluções adequadas às dificuldades iniciais. Propõe-se o filósofo, então, a seguir um modus operandi próprio ao pensar humano, ou seja, em linguagem atual o pleno uso dos processos cerebrais, que permitem o perscrutar-se o entorno de cada ser humano. Devem-se solver as dificuldades a partir das coisas, dos objetos por conhecer mais simples, portanto, não compostos, em direção paulatina aos mais complexos, sabendo-se de antemão que ainda deve-se importar com a precedência ou o 
aspecto temporal do fenômeno. Por último, o filósofo, propõe uma atitude extremamente cautelosa ao pensar humano, ao recomendar especificações, enumerações tão extensas, quanto completas, que aliadas a processos sucessivos de releituras se tenham a "certeza de não ter omitido nada".

Como entender em Descartes (2003:32), este conjunto de idéias? Vejamos o que nos ensina o filósofo:

Essas longas cadeias de razões (aqui entendidas como proporções) simples e fáceis, das quais os geômetras costumam servir-se para chegar às suas mais difíceis demonstrações, deram-me ocasião de imaginar que todas as coisas que podem cair sob o conhecimento dos homens seguem-se umas às outras da mesma maneira, e que, desde que se evite tomar como verdadeira alguma que não o seja, e se conserve sempre a ordem necessária para deduzi-las umas das outras, não podem existir tão longínquas que não se alcancem, nem tão ocultas que não se descubram. E não me foi muito custoso decidir por quais deveria começar, pois já sabia que havia de ser pelas mais simples e mais fáceis de conhecer e, considerando que, entre todos os que antes de mim procuraram a verdade nas ciências, apenas os matemáticos puderam encontrar algumas demonstrações, isto é, algumas razões certas e evidentes, não duvidei de que assim fora graças somente às que por eles fora examinadas, embora não esperasse delas nenhuma outra utilidade salvo a de que acostumariam o meu espírito a nutrir-se da verdade, sem se contentar com falsas razões.

Prossegue Descartes (2003: 33), a apresentar o Método, enquanto instrumento para o "bem pensar":

Em seguida, tendo notado que, para conhecê-las, precisaria, às vezes, considerá-las cada uma em particular, e, às vezes, somente ter em conta e compreender várias em conjunto, pensei que, para considerá-las melhor em particular, devia supô-las em linhas, pois não encontraria nada de mais simples nem que pudesse mais distintamente representar à minha imaginação e aos meus sentidos; mas, considerá-las ou compreendê-las várias em conjunto, era necessário que eu as indicasse por alguns signos, tão breves quanto possível. E assim, por esse meio, eu tomaria de empréstimo toda a melhor parte da análise geométrica e da álgebra e corrigiria todos os defeitos de uma e de outra.

Permanecendo no refletir cartesiano podem-se entender as máximas que o orientaram no abordar as idéias advindas de outros e como correlacioná-las com as suas próprias, Descartes (2003: 35-36) nos diz:

E entre diversas opiniões igualmente admitidas, eu só escolhia as mais moderadas, tanto porque são sempre as mais cômodas para a prática e verossimilmente as melhores, pois todo excesso em geral é mau, como 
também para me desviar menos do verdadeiro caminho quando induzido a errar; e isso porque, se tivesse escolhido um dos extremos, poderia ter sido o outro o que deveria ter tomado. (...) Imitava nisso os viajantes que, ao se verem perdidos numa floresta, não devem errar de um lado para outro, nem tampouco ficar no mesmo lugar, mas sim caminhar tão reto quanto possível, seguindo o mesmo rumo, sem nunca mudar de direção por fracas razões, mesmo quando, a princípio, tenha sido apenas o acaso o que determinou a escolha. (...) Minha terceira máxima consistia em procurar sempre vencer antes a mim do que à fortuna, em modificar antes os meus desejos do que a ordem do mundo, e, de um modo geral, em acostumar-me a acreditar que não há nada que esteja tão inteiramente em nosso poder como os nossos pensamentos, de maneira, depois de termos feito o melhor possível no que diz respeito às coisas que são exteriores, tudo o mais que não conseguimos nos sair bem é, em relação a nós, absolutamente impossível.

O refletir de Descartes é continuado ao se referir às proposições e em como discernir em cada uma delas a Aletheia e o Pseudo. Diz-nos o filósofo (2003:39):

(...) ao procurar descobrir a falsidade ou incerteza das proposições que examinava, não com fracas conjecturas, mas com raciocínios claros e seguros, não encontrava nenhuma tão duvidosa que dela não tirasse sempre alguma conclusão bastante certa, ainda que fosse esta: a de não conter nada de certo. E, assim como, ao derrubar uma casa velha, costumamos reservar o material da demolição para utilizá-lo na construção de uma nova, assim também, ao destruir todas as minhas opiniões que julgava mal fundadas, fazia diversas observações e adquiria muitas experiências que mais tarde me serviriam para estabelecer outras mais certas.

Descartes, em oposição ao legado aristotélico-tomista que primava pelo realismo, inicia o idealismo (confira-se no texto citado anteriormente, da lavra de Garcia Morente, 1980, onde o autor trata da "dificuldade do idealismo face à facilidade do realismo"). Com Descartes, em nosso entendimento (salvo melhor argumentação em contrário), vêem-se os primórdios do conhecimento do a priori, se for adequado entender-se este termo no sentido kantiano do mesmo, ou ainda, no entender atual de uma Filosofia da Biologia, na qual o $a$ priori corresponderia a processos endógenos, inclusive processo cerebral. portanto, nesse caso, algo que pertence às funções superiores do encéfalo, na formalização do pensar ciência. Senão, veja-se o texto a seguir de Descartes (2003: 44):

(...) e isso é bastante manifesto pelo fato de os próprios filósofos terem por máxima, nas escolas, que no entendimento nada existe que não tenha estado antes nos sentidos, nos quais, entretanto, é certo que as idéias de Deus e da alma nunca estiveram. Parece-me que os que querem usar a imaginação para compreendê-las procedem exatamente como se, para ouvir os sons ou sentir dor, quisessem servir-se dos olhos; sem falar da diferença que consiste no fato de o sentido da vista não nos garantir menos a verdade dos objetos do que os do olfato ou do ouvido, ao passo que nem a nossa imaginação nem os 
nossos sentidos poderiam jamais assegurar-nos de qualquer coisa, se o nosso entendimento não interviesse.

Esta sintética reflexão sobre uma aproximação do a priori se faz importante, pois a partir do pensamento cartesiano uma plêiade de filósofos entre eles, Leibniz, chega por diversas vias, a algo como uma aproximação do "a priori”. Porém, só em Kant encontrar-seão as reflexões que podem justificar a proposição de que o a priori seria a própria inteligência, como a entende Piaget, ou seja, enquanto processos neurais, a capacidade de pensar do ser humano. O que nos diz Garcia Morente sobre este conceito do a priori, quando o autor trata da "Gênese das verdades" (1980: 198-199) é o que veremos:

E o próprio Leibniz, nos seus Novos Ensaios, lembra a teoria da reminiscência, de Platão, aquele diálogo em que Sócrates chama a um escravo jovem, Menon, para demonstrar a seus ouvintes que esse rapaz também sabia matemática sem a ter aprendido, porque as matemáticas surgem, nascem no espírito por puro desenvolvimento dos germes racionais que estão nele. Neste sentido seminal, genético, germinativo, pode-se dizer que as verdades de razão são inatas. Mas, naturalmente, não no sentido ridículo de pensar que um ignorante, que um menino já sabe geometria. Porém, qualquer homem pode vir a conhecê-la e não precisa, para isso, da experiência, mas somente do desenvolvimento desses germes já existentes. Expressa isto Leibniz de uma maneira perfeita, clara, quando propõe que ao lema fundamental dos empiristas, ao velho adágio latino, aristotélico, de Nihil est in intellectu quod non prius fuerit in sensu (ou seja: "nada há no entendimento que não tenha estado antes nos sentidos"), se acrescente: Nisi intellectus ipse. Nada há no intelecto que não tenha estado antes nos sentidos, a não ser o próprio intelecto com suas leis, com seus germes, com todas essas possibilidades de desenvolvimento que não necessitam mais que desenvolver-se no contato com a experiência. Em suma: a teoria de Leibniz sobre a origem da verdade de razão descobre aquilo que, a partir dele, e, sobretudo em Kant, vamos chamar a priori.

\section{D) O Método em Kant: verdades de fato e verdades da Razão. Os perigos da anfibolia transcendental.}

O estudo, a reflexão sobre o caráter apriorístico das verdades de razão, citados logo acima no texto de Garcia Morente, nos permite, por conseqüência, reafirmar a proposição, de que este apriorismo das verdades de razão é processo neural, portanto, atividade superior do encéfalo humano. Em contraposição às verdades de razão estão às verdades de fato, estas sim oriundas da experiência, pois chegam estas, até nós, pelos órgãos dos sentidos, nos levam até a capacidade aperceptiva das sensações presente no córtex temporal. 
O Método em Kant, tendo-se como referência a Crítica da Razão Pura é encontrado sob três denominações, quais sejam, o Método Crítico (presente na Lógica Transcendental e na Analítica Transcendental), O Método Cético (presente nas Antinomias da Razão Pura) e o Método como Doutrina Transcendental, que pressupõe uma disciplina, um cânone e uma arquitetônica.

Kant, ao se reportar ao Método Crítico o fez levando em consideração que, para instituir uma metodologia crítica da Razão haveria a necessidade de se fixar um ponto inicial, algo tanto incontestado quanto incontestável, ou seja, o conteúdo objetivo da consciência. Sem que houvesse a preocupação neste conteúdo, nem com o sujeito psicológico, nem com a representação de um objeto ontológico, mas o conteúdo enquanto objeto fenomênico. Haveria aqui, um viés subjetivo, que poderia ser alvo de crítica, o partir-se do conhecimento do objeto como fenômeno? Diz-nos Kant que não. Pois, bastaria abstrair-se disto a distinção metafísica de sujeito e objeto. Poderia haver também um entendimento "dogmático" no partir-se do “conhecimento do objeto como fenômeno", Kant também nesta outra situação nos ensina que não, pois, nada impediria que diante de um problema complexo, metodicamente se examinasse cada elemento do problema, portanto, de forma analítica poder-se-ia chegar à solução do referido problema.

O fenômeno para Kant é a unidade mais elementar da consciência, em algum momento haveria a necessidade de objetivação do fenômeno, se, se busca efetivamente o seu entendimento. Um Método Crítico, para o filósofo, não pode julgar nada de forma arbitrária. A forma descrita por Kant para a possibilidade do julgar o fenômeno é fundamentada na possibilidade analítica dos "conteúdos da consciência", que, no entanto, deve respeitar as relações naturais dos elementos que foram dissociados ou decompostos, ou ainda deduzidos. O método analítico seria constituído da decomposição dos conceitos em seus elementos constitutivos e desta forma aclará-los-ia. Kant (1994: 112-113) nos diz:

As categorias ligadas aos modos da sensibilidade pura ou mesmo ligadas entre si fornecem grande quantidade de conceitos a priori derivados, que seria tarefa útil e até agradável indicar e porventura consignar exaustivamente, mas que é, neste caso, dispensável. Dispenso-me também, deliberadamente, neste tratado, das definições dessas categorias, embora gostasse de estar de posse delas. Posteriormente analisarei (grifo nosso) estes conceitos até onde seja suficiente para a metodologia_(grifo nosso) que elaboro. Num sistema da razão pura poder-me-iam ser justificadamente exigidas; mas aqui desviariam apenas a atenção do ponto de vista principal 
da investigação, suscitando dúvidas e objeções, que bem se poderão remeter para outra oportunidade, sem prejuízo do nosso desígnio fundamental. Entretanto, do pouco que a esse propósito apresentei, se depreende claramente que não só é possível como até fácil elaborar um dicionário completo com todos os esclarecimentos desejáveis. As divisões já existem; basta preenchê-las e, numa tópica sistemática, como a presente, é difícil errar a colocação adequada de cada conceito, ao mesmo tempo que facilmente se descobrem os lugares ainda vagos.

Kant, ainda nos ensina que à margem do método analítico da Lógica clássica, há outra análise a ser feita, que não preconiza o discernir os objetos, ou ainda, o distinguir notas objetivas, consistiria, isto sim, em penetrar até a estrutura própria, ou ainda às condições internas das possibilidades do objeto do pensar, enquanto objeto.

A análise adequada de uma metodologia crítica pode nos dar o que Kant denomina de "princípios das possibilidades" do conhecimento objetivo, portanto, princípios que sejam logicamente prévios aos conhecimentos particulares que eles intrinsecamente determinam. Toda análise decompõe uma síntese, a análise acima referida decompõe a "síntese objetiva" nos seus elementos complementares, materiais e formais que a constituem como tal. Fundamenta-se desta forma o que se denomina de Método Crítico sob o olhar kantiano, advertindo-se de antemão o caráter sintético desta reflexão.

Kant ao tratar da Anfibolia, dos conceitos da reflexão resultante da confusão do uso empírico do entendimento com o seu uso transcendental, dos Paralogismos da Razão Pura e da Antinomia da Razão Pura, nos fala de um Método Cético que possibilitaria o solverem-se estas temáticas, nos diz que (1994: 447): “A Dialética Transcendental não favorece, pois, de modo algum, o ceticismo, mas sim o método cético, que nela dá mostras da sua grande utilidade. (...). Busquemos em Kant o que seria este Método Cético, e como ele proporciona uma reflexão sobre a prova, enquanto, demonstração científica e ainda mostra outro caminho no solucionarem-se os conflitos lógicos do Entendimento (Verstand).

O Método Cético do filósofo de Königsberg já se delineia quando ele ao tratar, na Lógica Transcendental no segundo livro, denominado de Analítica dos Princípios, o estudo da: faculdade de julgar transcendental, do esquematismo dos conceitos puros do entendimento, do princípio supremo de todos os juízos sintéticos, dos axiomas da intuição, da antecipação da percepção, das analogias da experiência, do princípio da distinção de todos os objetos em geral em fenômenos e númenos. O filósofo se detém aqui na anfibolia dos 
conceitos da reflexão, que resultam daquilo que ele chama de confusão do uso empírico do entendimento com seu uso transcendental. Lalande (1999:67) define anfibolia como: "duplo sentido de uma locução ou frase. Propomos utilizar de preferência ambigüidade para as palavras ou os termos, anfibolia para as frases ou as proposições, e equívoco no sentido geral".

Para Kant (1994: 274), "a reflexão (reflexio) não tem a ver com os próprios objetos, para de eles receberem diretamente conceitos; é o estado de espírito em que, antes de mais, nos dispomos a descobrir as condições subjetivas pelas quais podemos chegar a conceitos."

Esta reflexão é vista pelo filósofo como relação entre a consciência das representações e as nossas diferentes fontes do conhecimento. Levanta aí o filósofo algumas questões, quais sejam: estas representações se encontrariam em que faculdade do conhecimento? As ligações e comparações que permeiam estas relações se fariam pelo entendimento ou pelas sensações? Kant na mesma página acima referida nos diz: “Alguns juízos são aceitos por hábito ou ligados por inclinação; mas, por não haver reflexão que os preceda ou, pelo menos, se lhes siga criticamente, admite-se que têm origem no entendimento". Pode-se perceber que neste caminho ou via reflexiva nem todo o ato de julgar exige um exame nos ensina Kant, os juízos matemáticos ou da geometria devido ao pensar que independe da experiência por ser imediato indica uma verdade imediata, não necessita de exame, mas não prescinde da prova, aqui, enquanto meio que a inteligência usa na busca desta verdade. Kant (1994: 274-275) assim se manifesta:

Mas todos os juízos, e mesmo todas as comparações, carecem de uma
reflexão, isto é, de uma discriminação da faculdade de conhecimento a que
pertencem os conceitos dados. O ato pelo qual confronto a comparação das
representações em geral com a faculdade do conhecimento, onde aquela se
realiza, e pelo qual distingo se são comparadas entre si como pertença do
entendimento puro ou da intuição sensível, é o que denomino reflexão
transcendental. Ora, as relações, pelas quais os conceitos se podem ligar uns
aos outros num estado de espírito, são as de identidade e diversidade, de
concordância e oposição, de interioridade e exterioridade, e por fim, de
determinável e determinação (de matéria e de forma). A determinação exata
desta relação consiste em saber em que faculdade de conhecimento se liga
subjetivamente uns aos outros, se na sensibilidade ou no entendimento.
Porquanto a diferença destas faculdades constitui uma grande diferença no
modo como se devam pensar os conceitos.

A anfibolia enquanto confusão do uso empírico do Entendimento com seu uso transcendental, ou ainda duplo sentido de uma locução ou frase, é vista em Kant antes daquilo 
que ele chama de "juízos objetivos". Por meios comparativos deve a inteligência (intellectus) tanto na ótica cartesiana, quanto principalmente sob o olhar kantiano estabelecer os conceitos acima referidos de identidade e diversidade, aquela sob as várias representações do termo subordinadas a um respectivo conceito, tendo como objetivo os "juízos universais", esta naquilo que Kant chama de "produção de juízos particulares"; definindo o filósofo que da concordância resultariam "juízos afirmativos", da denominada oposição adviriam os "juízos negativos"; e a matéria e a forma que a ótica kantiana nos diz: (1994: 277) "São dois conceitos que servem de fundamento a todas as demais reflexões, de tal modo estão indissoluvelmente ligados a todo uso do entendimento".

Os conceitos e as relações que ligam uns aos outros, tem como método aquilo que Kant chamou de "conceitos de comparação" (conceptus comparationis), conceitos estes que o filósofo assim define (1994: 275):

Quando se trata, porém, não da forma lógica, mas do conteúdo dos conceitos, isto é, de saber se as próprias coisas são idênticas ou diversas, concordantes ou opostas, etc., essas coisas podem ter uma relação dupla com a nossa capacidade de conhecimento, ou seja, com a sensibilidade e com o entendimento; e como do lugar a que pertencem depende o modo como se devem articular umas com as outras, só a reflexão transcendental, isto é, a relação de representações dadas com ou outro modo de conhecimento, poderá determinar a relação das representações entre si.

Temos aqui, uma determinação que, só a simples comparação dos conceitos não atende aos propósitos de Kant, pois, haveria a necessidade de uma prévia discriminação do "modo do conhecimento" a que pertenceria cada um dos conceitos relacionados e partir de uma "reflexão transcendental", se atingiriam o proposto inicialmente pelo filósofo. Kant compara então, a denominada "reflexão lógica" de origem aristotélica, que promove a "simples comparação" e não trata da faculdade de conhecimento a que "pertencem às representações dadas", tornando homogêneo o seu lugar no espírito, com a reflexão transcendental que segundo o filósofo se dirige aos próprios objetos e conteria o "princípio da possibilidade da comparação objetiva" de cada representação entre si, pois, a "faculdade de conhecimento" a que pertencem estas representações não são as mesmas. Para Kant (1994: 276): "Esta reflexão transcendental é um dever a que ninguém, que pretenda a priori formular qualquer juízo sobre as coisas, se pode eximir". 
As relações que o filósofo entende permitirem ligar os conceitos uns aos outros "num estado de espírito" são: de identidade e diversidade, de concordância e oposição, de interioridade e exterioridade e ainda de determinável e determinação, já foi visto; vale à pena ressaltar o que cada um destes conceitos enquanto submetidos à sensibilidade e o entendimento resultam em diferentes significados. Estes conceitos acima referenciados têm importância capital na ambiência da Medicina Legal. O conceito de identidade, por exemplo, é tema especial e objeto de estudo e de conhecimento nesta ciência. Vejam-se como Kant trata estes conceitos e qual a importância dos mesmos no se fazer ciência.

A identidade estudada na Medicina Legal se refere a "aquela deduzida por perito após observação de corpo vivo ou cadáver”, é estudada também enquanto atributo de algo que "permanece" ou fica sempre igual, ou ainda, a consciência da permanência ou persistência da própria personalidade. Kant (1994: 276) assim manifesta o seu entendimento sobre a identidade e a diversidade:

Quando um objeto nos é representado freqüentemente e de cada vez com as
mesmas determinações internas (qualitas et quantitas), esse objeto, como
objeto do entendimento puro, é sempre o mesmo, não muitas coisas, mas
uma só coisa (numerica identitas); se, porém, é fenômeno, já não se trata de
comparar conceitos, pois, por muito idêntico que seja tudo com respeito a
estes, a diversidade dos lugares que ocupa esse fenômeno num mesmo
tempo é fundamento bastante da diversidade numérica do objeto (dos
sentidos). (...) Todavia, como os fenômenos são objetos da sensibilidade e
em relação a eles o entendimento não tem uso puro, mas apenas empírico, a
pluralidade e a diversidade numéricas já são dadas pelo próprio espaço como
condição dos fenômenos externos.

O elemento regulador da identidade nesta ótica estaria centrado no conceito kantiano do espaço enquanto intuição externa, em contraposição ao tempo entendido como intuição interna. Kant cita então a guisa de exemplo: de duas gotas de água ao abstrair se toda a diversidade de qualidade e quantidade basta que se intua as mesmas em lugares diferentes para que se possa considerá-las numericamente diversas. A separação entre o objeto e o fenômeno na ambiência da Medicina Legal estaria sumamente complicada não fora esta reflexão kantiana sobre o elemento regulador da identidade enquanto conceito que permite a anfibolia quando existe o pensar confuso entre o uso transcendental e o uso empírico do mesmo. 
A díade seguinte, ou seja, a concordância e a oposição é tratada por método comparativo, onde se compara a realidade enquanto númeno (realidade tal como existe em si mesma, de forma independente da perspectiva necessariamente parcial em que se dá todo o conhecimento humano, a coisa em si), daquela advinda da realidade enquanto fenômeno, nos diz Kant (1994: 277):

Quando a realidade nos é representada somente pelo entendimento puro (realitas noumenon), não se pode pensar qualquer oposição entre as realidades, isto é, uma relação tal que, ligadas essas realidades num sujeito, anulem reciprocamente as suas consequiências e que 3 - $3=0$. Em contrapartida, o real no fenômeno (realitas phaenomenon) pode certamente conter oposições e, reunida no mesmo sujeito, pode uma realidade aniquilar totalmente ou em parte a conseqüência da outra, tal como duas forças motrizes, na medida em que atuam na mesma linha reta, atraem ou impelem um ponto em direção opostas, ou como um prazer que contrabalança uma dor.

Os conceitos enquanto representações de interno e externo são elaboradas enquanto objetos do entendimento puro e enquanto relações no espaço, Kant nos ensina que (1994: 277):

Num objeto do entendimento puro, só é interno o que não tem qualquer relação (quanto à existência) com algo diferente de si. Pelo contrário, as determinações internas de uma substantia phaenomenon no espaço mais não são que relações e a própria substância é totalmente um conjunto de puras relações. Só conhecemos a substância no espaço por intermédio de forças que agem nesse espaço, que para trazer para ele outras forças (atração), quer para evitar a sua penetração (repulsão ou impenetrabilidade); não conhecemos outras propriedades, que constituam o conceito de substância que aparece no espaço e que denominamos matéria. Como objeto do entendimento puro, pelo contrário, todas as substâncias devem ter determinações e forças internas, que se refiram à realidade interna.

A última díade que Kant denomina de determinável e determinação é vista por ele através da matéria e da forma, conceitos estes que fundamentam "todas as demais reflexões, nos diz o filósofo". A matéria significa para ele o que é "determinável em geral", a forma seria a "determinação", leve-se em consideração que estas proposições estão ditas aqui no sentido do "transcendental" kantiano, para quem se deve "abstrair toda a diferença entre o que é dado e a maneira como é determinado" (1994: 278). O que nos diz Kant nesta mesma página:

Os lógicos, antigamente, davam o nome de matéria ao geral, e o de forma à diferença específica. Em todo o juízo, podem chamar-se aos conceitos dados, matéria lógica (para o juízo), e a relação entre eles (mediante cópula) a 
forma do juízo. Em todo o ser, os elementos constitutivos (essentialia) são a matéria; a maneira como esses elementos estão ligados numa coisa é a forma essencial.

O Entendimento (Verstand) puro, conceito kantiano, define que a matéria precede a forma, (precisamente nesse caso do Entendimento que, lembremos, faz a ligação entre a Razão e o mundo) de onde se pode perceber que, em primeiro lugar é necessário que algo seja dado e posteriormente poder-se determinar esse algo de alguma maneira. Ao se ter algo que é dado, por conseqüência se chega à representação desse algo. Segundo o filósofo, a intuição do tempo e do espaço é possível, o espaço através da relação das substâncias e o tempo pela ligação do que Kant chama de determinações destas entre si como princípios e conseqüências. Nas páginas (278-280) Kant assim se refere:

Mas, como a intuição sensível é uma condição subjetiva muito particular,
que é fundamento a priori de toda a percepção, e cuja forma é originária,
assim, a forma é dada por si só, e não é a matéria (ou as próprias coisas que
aparecem), longe disso, que serve de fundamento (como se deveria julgar
segundo simples conceitos); a sua possibilidade supõe, pelo contrário, uma
intuição formal (o espaço e o tempo) como dada.) Seja-me permitido dar o
nome de lugar transcendental à posição que atribuímos a um conceito, quer
na sensibilidade, quer no entendimento puro. Assim, a determinação do lugar
que compete a cada conceito, conforme a diversidade do seu uso e as regras
que ensinam a determinar o lugar de todos os conceitos, seria a tópica
transcendental. (...) A tópica transcendental, pelo contrário, inclui apenas os
citados quatro títulos de toda a comparação e de toda a distinção, que
diferem das categorias em não representarem o objeto, segundo o que
constitui o seu conceito, mas somente, em toda a sua diversidade, a
comparação das representações que precedem o conceito das coisas.(...) Os
conceitos podem ser comparados, logicamente, sem cuidar de saber a que
lugar pertencem os seus objetos, se, como númenos, ao entendimento ou
como fenômenos, à sensibilidade.

Kant nos ensina no texto acima, que é necessária uma reflexão transcendental e por meio desta se chegar a identificar qual a faculdade de conhecimento devem ser objetos, o entendimento e a sensibilidade enquanto conceitos. Pode-se perceber que sem esta reflexão nos legada pelo filósofo, se estaria inseguro da clareza e da distinção (clareza e distinção no sentido cartesiano dos termos) destes conceitos, impossibilitando a Razão de reconhecê-los, pois os conceitos se fundariam naquilo que Kant chamou de anfibolia transcendental, advinda da "confusão entre o objeto puro do entendimento e o fenômeno".

O método cético, por sugerir um "ceticismo" que não existe na filosofia kantiana exige uma reflexão mais alongada, nos leva a observação das antinomias, nos remete ainda a 
um refletir pragmático como o refletir cartesiano, que pressupõe idéias claras e distintas. A reflexão sobre as antinomias da Razão Pura e dos Paralogismos deve ser iniciada com um olhar sobre o que seria a antinomia e o paralogismo.

Antinomia em Kant significa contradição entre duas proposições filosóficas igualmente críveis e lógicas, ou coerentes, que chegam a conclusões opostas, significando os limites do processo cognitivo do intelecto humano. Para Garcia Morente, o que seria a antinomia kantiana? Veja-se o que nos diz o autor e filósofo (1980: 250):

Muito mais interessante é a discussão que Kant consagra ao segundo
problema da metafísica: o problema do universo. O método de discussão
nessa segunda parte consiste naquilo que Kant chama antinomias da razão
pura. Quer dizer o seguinte: se nós adotamos o ponto de vista dos
metafísicos e consideramos o universo como uma coisa em si e tentamos
predicar do universo propriedades metafísicas, deparamos com este
surpreendente resultado: que do universo podemos predicar afirmações
contraditórias, e, não obstante serem contraditórias, as duas afirmações são
igualmente demonstráveis, com igual força probatória. Cada uma dessas
contraposições de tese e antítese, igualmente probatórias acerca do Universo,
chama-as Kant antinomias; e descobre na metafísica quatro antinomias.

Paralogismo é definido correntemente por: raciocínio falso cometido involuntariamente. Kant define quatro modalidades de paralogismos: da substancialidade, da simplicidade, da personalidade, da idealidade (da relação externa). Antes que se cheguem às antinomias, busquemos ver como Kant definia estes paralogismos e sua importância, pois tanto os paralogismos como as antinomias fazem parte do capítulo da Crítica da Razão Pura, denominado: “dos raciocínios Dialéticos da Razão Pura”.

Kant define paralogismo lógico aquele que: "consiste na falsidade de um raciocínio quanto à forma, seja qual for, de resto, o seu conteúdo. Mas um paralogismo transcendental tem um fundamento transcendental, que nos faz concluir, falsamente, quanto à forma”.

"Kant, ao definir, o valor das idéias transcendentais, o faz, informando que estas "idéias", corresponderiam aos assim chamados "incondicionados", temas estes presentes na Metafísica. Tais incondicionados em número de três seriam os seguintes: a "unidade absoluta do sujeito lógico", aqui entendida como objeto lógico, não sendo outra coisa que aquilo que o filósofo chamou de "sujeito pensante"; seria assim, a primeira idéia transcendental o eu pensado como substância, objeto, portanto, da Psicologia. A segunda idéia seria a "unidade absoluta das séries causais da experiência", que não poderia persistir a não ser em um mundo 
organizado, em cujo âmago se constitui uma série de ligações entre causas e efeitos que levaria como também dizia Aristóteles a uma causa não causada, portanto, objeto de estudo da Metafísica, tanto na visão aristotélica quanto kantiana. Esta segunda idéia seria, então, a "causalidade cósmica", ou seja, uma idéia do mundo, enquanto objeto de uma reflexão fundada na Razão. A terceira idéia estaria contida na proposição de uma "unidade absoluta e incondicionada de todos os objetos da mente em geral", conteria esta idéia a referência de uma condição suprema da possibilidade de tudo que pode ser pensado, especialmente sobre o ser em si, confunde-se, assim, tal idéia, com a idéia de Deus.

Kant submeteu estas três idéias transcendentais a uma severa crítica racional, gerando um método, que ele definiu na Analítica Transcendental, método este a quem Kant atribuiu contraprova.

A primeira idéia transcendental, ou seja, o eu pensado como substância, ou melhor, como unidade subsistente, resume após a devida crítica kantiana, toda a reflexão sobre os paralogismos da Razão Pura. O filósofo de Königsberg chama de paralogismos da Razão Pura aos raciocínios sofistas que concluiriam as principais propriedades transcendentais deste $e u$ enquanto substância; a pormenorização dos paralogismos é tema para um estudo de Psicologia Racional. Kant criticou tal Psicologia; nas reflexões de Garcia Morente veja-se o que o autor denomina de "Erro da Psicologia Racional", (1980:250):

Em primeiro lugar, Kant ataca aquilo que ele chama Psicologia Racional, ou seja, a parte da Metafísica encaminhada a mostrar que a alma é simples e, por conseguinte, imortal. Kant faz ver que nós não podemos predicar da alma absolutamente nada; porque a alma não pode ser objeto a conhecer, não pode ser fenômeno dado na experiência. Na experiência, no tempo, que é onde se dão os fenômenos anímicos, a única coisa que obtemos quando olhamos para nós mesmos é uma série constante de vivências que vão substituindo-se umas às outras (agora uma vivência, logo outra vivência, depois esta outra) e que, ademais, cada uma das vivências tem em si, dentro de si, um sinal duplo: é, de um lado, vivência de um eu, e de outro lado, vivência de uma coisa; mas não encontramos nenhuma vivência que possa ser considerada como isto que chamamos de alma. Portanto, não podemos, sem transgredir as leis essenciais do conhecimento, considerar a alma como uma coisa a conhecer. Teríamos que extrair, tirar o tempo, que é o caminho ou o trilho geral por onde discorre nossas vivências, para encontrar fora do tempo isto que chamamos alma, substância simples, imortal. Mas nos não podemos sair do tempo, visto que o tempo é, juntamente com o espaço, a primeira das condições de todo conhecimento possível. Assim, a psicologia metafísica comete uma transgressão, comete uma totalização indevida, apresentando-nos a substância "alma" como algo fora do tempo. 
A idéia do $e u$ subsistente, para Kant, leva às seguintes reflexões: esta idéia, de um lado é sustentada nas ligações pertinentes aos juízos categóricos. Estas ligações ou sequiências naturais de juízos empíricos nos encaminham até um princípio cujo sujeito já não pode ser predicado de nenhum juízo. Estar-se-ia diante de um sujeito absoluto, desde que se considere este como último de uma série empírica, se apresentando de forma objetiva, o que, data vênia, convém a uma série empírica. Se aceitarmos este argumento como hipótese de que se pode referendar o sujeito absoluto concebido como "objeto", este sujeito absoluto e incondicionado (veja-se aqui a analogia com a causa não causada de Aristóteles) estaria situado na categoria de "substância", posto que, naquilo que Kant chama de "representação" do objeto, este sujeito estaria na condição (aqui, um paradoxo, pois se é incondicionado não pode ser submetido a nenhuma condição) do substrato mais profundo e na permanência absoluta. Este é o sentido daquilo que Kant chama de maior raciocínio do paralogismo, resumido na seguinte proposição: o que não pode ser pensado senão como sujeito, não pode existir também senão como sujeito, deve (concluindo-se esta espécie de silogismo), portanto, ser substância.

Olhando-se de outra maneira, ou seja, um olhar sobre o que se pode denominar de paralogismo menor, Kant na Analítica Transcendental afirma que o sujeito pensante tem consciência dele mesmo, conhece ele mesmo como unidade da apercepção, como condição $a$ priori que leva à unidade da própria consciência, totalizando-se aí toda a diversidade das representações dos objetos e dos fenômenos da experiência. Parece que, o conhecer-se como princípio interno da unidade das diversas representações, seria o se conhecer como o sujeito ou substrato dessas representações. Podendo-se resumir o paralogismo menor na seguinte proposição: um ser pensante, se considerado sob o aspecto de ser pensante, não poderia ser pensado senão como sujeito e por conseqüência como substância.

Com a devida vênia, tanto a argumentação do "maior" quanto do "menor" é paralogismo. Senão, veja-se o que nos ensina Kant (1994: 332):

Mostramos, na parte analítica da lógica transcendental, que as categorias puras (e entre estas também a da substância) em si mesmas não têm nenhuma significação objetiva se não lhes estiver subjacente uma intuição, ao diverso da qual podem ser aplicadas como funções da unidade sintética. Sem isso, são meramente funções de um juízo sem conteúdo. De cada coisa em geral posso dizer que é substância, contanto que a distinga de simples predicados e de simples determinações das coisas. Ora, em cada um dos nossos pensamentos, o $\mathrm{eu}$ é o sujeito ao qual os pensamentos são inerentes como simples determinações e este $e u$ não pode ser utilizado como a 
determinação de uma coisa. Portanto, cada um deve considerar-se a si mesmo, necessariamente, como uma substância e os seus pensamentos, porém, apenas como acidentes da sua existência e determinações do seu estado. Que uso devo fazer agora deste conceito de substância? Não posso, de maneira alguma, concluir que eu, como ser pensante, durmo por mim próprio, sem nascer nem morrer naturalmente, e, contudo, é só para isso que me pode ser útil o conceito da substancialidade do meu sujeito pensante; sem esse uso podê-lo-ia muito bem dispensar. É tão errado que se possam concluir essas propriedades a partir da simples categoria pura de uma substância, que, pelo contrário, somos obrigados a tomar por fundamento a permanência de um objeto dado, extraído da experiência, se quisermos aplicar-lhe o conceito, empiricamente utilizável, de uma substância. Ora, não pusemos nenhuma experiência como base da nossa proposição, mas simplesmente passamos do conceito de relação, que todo o pensamento implica, para o eu como o sujeito comum ao qual está inerente. Não poderíamos, mesmo se tomássemos a experiência por base, provar uma tal permanência por uma observação segura. Com efeito, é verdade que o eu se encontra em todo o pensamento, mas a esta representação não está ligada à mínima intuição que o distinga dos outros objetos da intuição. Portanto, pode-se, sem dúvida, admitir que esta representação reaparece sempre em todo o pensamento, mas não que seja uma intuição fixa e permanente, onde se sucedem os pensamentos (como variáveis). Daqui se segue que o primeiro raciocínio da psicologia transcendental nos traz apenas uma pretensa luz nova, dando-nos o sujeito lógico permanente do pensamento pelo conhecimento do sujeito real de inerência, do qual não temos nem podemos ter o mínimo conhecimento, porque a consciência é a única coisa que torna todas as representações em pensamento e onde, portanto, devem ser encontradas todas as nossas percepções, como no sujeito transcendental; e, fora dessa significação lógica do $e u$, não temos nenhum conhecimento do sujeito em si que, na qualidade de substrato, esteja na base desse sujeito lógico, bem como, de todos os pensamentos.

Kant dá seqüência ao refletir sobre os paralogismos, nesse momento chega-se, ao paralogismo da simplicidade, denominado pelo filósofo de "o Aquiles de todos os raciocínios dialéticos da psicologia pura", seu enunciado, sugere algo lógico de difícil refutação, consiste este enunciado no seguinte: "uma coisa, cuja ação nunca pode ser considerada como a concorrência de várias coisas atuantes, é simples. Ora, a alma, ou o eu pensante, é uma coisa desse gênero". Garcia Morente, em texto acima sobre o "Erro da psicologia racional", demonstra o paralogismo existente em se querer tratar a alma como objeto a conhecer. $\mathrm{O}$ terceiro paralogismo é denominado "da personalidade". O quarto paralogismo é definido por Kant como o da "idealidade". A reflexão feita sobre a crítica do paralogismo da substancialidade por constituir o método, pelo qual o filósofo responde metodologicamente aos paralogismos, é em nosso entendimento, suficiente para exemplificar a importância temática do assunto, nesta fundamentação do método, como capítulo desta Tese. 
Antinomia correntemente tem o significado de contradição entre duas leis ou princípios na sua aplicação prática a um caso particular, nos ensina Lalande (1999: 72). Para Kant, na Dialética Transcendental (1994: 379-400), a antinomia seria "conflito entre as leis da Razão Pura”.

Garcia Morente (1980: 250) em texto já citado acima nos diz que: "muito mais interessante é a discussão que Kant consagra ao segundo grande problema da Metafísica; o problema do universo". Estamos diante das denominadas Idéias Cosmológicas, que devem ser consideradas objetivamente, expressando desta maneira a "unidade incondicionada das condições objetivas dos fenômenos". Kant nas páginas acima referidas apresenta a forma mais geral destas idéias cosmológicas, no seguinte enunciado: "Se um condicionado é dado, ele é também a soma de suas condições, por conseguinte, é dado o incondicionado absoluto, o único que torna possível o condicionamento. Porém os objetos dos sentidos (os fenômenos) nos são dados como condicionados". Pode-se intuir daí que a totalidade das condições do fenômeno chega com ele. O pensar kantiano sobre este enunciado, é feito com a seguinte reflexão: é simplesmente fora de qualquer dúvida que o conceito de "condicionado" implica por sua vez a relação a uma "condição", e, se esta é mostrada por sua vez como condicionada, supõe-se uma "condição posterior" e assim sucessivamente. Isto remete necessariamente a uma regressão em série das condições, o que evidencia uma proposição analítica. Kant nos leva mais longe; suponha-se que o condicionado se dê fora do tempo, como "númeno", "coisa em si”, nesta ordem do absoluto, todas as ligações das condições regressivas, que dependem umas das outras, não se dão sob o mesmo titulo. Pois, levadas ao absoluto, as séries causais significam um conjunto indivisível das condições de possibilidade de um objeto independente do sujeito. As séries causais ordenam fenômenos que estão no tempo; tais séries não se apresentam como condições do "ser", mas aparecem e influenciam nossa razão no sentido de que elas se sucedem no tempo. Kant (1994: 379) nos diz:

$\mathrm{Na}$ introdução a esta parte da nossa obra mostramos que toda aparência transcendental da razão pura assenta sobre raciocínios dialéticos, cujo esquema é dado pela lógica nas três espécies formais dos raciocínios em geral, à semelhança das categorias, que encontram o seu esquema lógico nas quatro funções de todos os juízos. A primeira espécie destes raciocínios sofísticos referia-se à unidade incondicionada das condições subjetivas de todas as representações em geral (do sujeito ou da alma), e correspondia aos raciocínios categóricos, cuja premissa maior, como princípio, enuncia a relação de um predicado com um sujeito. A segunda espécie de argumentos dialéticos, por analogia com os raciocínios hipotéticos, terá por conteúdo a 
unidade incondicionada das condições objetivas no fenômeno; quanto à terceira espécie, de que se ocupará o capítulo seguinte, tem por tema a unidade incondicionada das condições objetivas da possibilidade dos objetos em geral.

Atendendo-se à "terceira espécie" do texto kantiano acima, dever-se-ia reduzir a conclusão dos raciocínios cosmológicos à mesma condição dos raciocínios psicológicos anteriores, levando tanto um quanto outro raciocínio, para uma idéia de "objeto problemático". Sem dúvida, um exame mais detalhado de ambos os raciocínios mostra uma grande diferença. Como na ordem psicológica a "aparência transcendental" mostra a falta de uma prova rigorosa de seu valor objetivo, porém consegue escapar de uma contradição lógica, permanecendo toda esta ordem em defesa do $E u$ enquanto substância (atente-se aqui ao texto sobre os paralogismos já referidos acima), de um sujeito das representações, além do empírico. Resumindo, em prol de um "incondicionado verdadeiro"; ocorre de outra maneira a abordagem na ordem cosmológica, aqui, se aplica à Razão a "síntese" objetiva dos fenômenos. O raciocínio, em lugar de carecer simplesmente de força probatória, se precipita, por menos que se perceba, em manifestas contradições, encontra-se em uma "antitética", situação natural, na qual a Razão humana cai freqüentemente. Kant (1994: 380) nos ensina:

Aqui se apresenta, com efeito, um novo fenômeno da razão humana, ou seja, uma antitética perfeitamente natural, onde ninguém carece de sutilezas nem de engenhosas armadilhas para atrair a razão que, pelo contrário, nela espontaneamente e até inevitavelmente se lança; assim se preserva de adormecer numa convicção imaginária, produzida por uma aparência meramente unilateral, mas, ao mesmo tempo, corre o risco de se entregar a um desespero cético ou de firmar-se numa obstinação dogmática, persistindo teimosamente em determinadas afirmações, sem dar ouvidos nem prestar justiça aos argumentos contrários. Ambas as atitudes são a morte de uma sã filosofia, embora a primeira ainda possa, de qualquer modo, merecer o nome de eutanásia da razão pura. Antes de apresentar as cenas de discórdia e dissensão que provoca este conflito de leis (esta antinomia) da razão pura, daremos certos esclarecimentos que podem explicar e justificar o método (grifo nosso) que usamos pra tratar do nosso assunto. Dou o nome de conceitos cosmológicos a todas as leis transcendentais, na medida em que se referem à totalidade absoluta na síntese dos fenômenos; em parte, devido a essa mesma totalidade incondicionada sobre a qual também assenta o conceito de universo, que não é ele mesmo senão uma idéia; em parte, porque apenas se referem à síntese dos fenômenos, síntese empírica, portanto, ao passo que, em contrapartida, a totalidade absoluta na síntese das condições de todas as coisas possíveis em geral dará origem a um ideal da razão pura, inteiramente diferente do conceito cosmológico, embora em relação com ele. Assim, tal como os paralogismos da razão pura lançaram o fundamento de uma psicologia dialética, também a antinomia da razão pura colocará diante dos olhos os princípios transcendentais de uma pretensa cosmologia pura (racional), não para a considerar válida e dela se apropriar, mas, como já indica a expressão de conflito da razão, para a revelar na sua aparência deslumbrante, mas falsa, como uma idéia que não se pode conciliar com os fenômenos.

Esta antinomia se apresenta através de tantos pares de teses e antíteses, quantos grupos fundamentais de idéias cosmológicas existirem. Pode-se com certa facilidade delimitar $a$ 
priori as distintas ordens possíveis destas idéias. As idéias transcendentais nos parecem, não seria, outra coisa, que categorias estendidas até o incondicionado. No entanto, como as idéias transcendentais cosmológicas devem expressar a totalidade das condições regressivas, ou ainda, os pressupostos do objeto, não poderiam se enquadrar, mas que nas categorias, de onde a função sintética inclui uma série de condições subordinadas entre si e não simplesmente coordenadas, com relação a um condicionado.

Kant nos demonstra a categoria da quantidade aplicada ao tempo enquanto transcorrido e na apreensão sintética do espaço; a categoria da qualidade no sentido de que a realidade de um todo fenomênico no espaço, portanto, de uma matéria, tem como condição racional última a integridade absoluta na divisibilidade deste todo, de tal maneira que, se reduz a zero, alguma coisa que não seja matéria, ou seja, o simples. Percorre ainda o filósofo as categorias da relação, da causalidade, da modalidade, da contingência, num movimento que conduziria a Razão, de condição em condição, até aquilo que ele denominou de "necessidade absoluta”, acabando assim toda série objetiva. Vê-se assim, em toda sua naturalidade, a Razão se mover em direção aos diversos caminhos estabelecidos por estas categorias que chegarão às antinomias, a esta contradição essencial que Kant chama de "Antinomia da Razão Pura".

Kant propõe solução para as antinomias. Colocado entre as teses e antíteses, o Entendimento, encontrar-se-ia indiferente para adotar umas ou outras? O filósofo nos responde que não. Kant (1994: 388-399) assim fala da "antitética da Razão Pura":

Se a tética é todo o conjunto de teorias dogmáticas, por antitética entendo não afirmações dogmáticas do contrário, mas o conflito de conhecimentos dogmáticos em aparência (thesis cum anthesi), sem que se atribua a um, mais do que ao outro, um direito especial à aprovação. A antitética não se ocupa, pois, de asserções unilaterais, considera unicamente conhecimentos gerais da razão no conflito dos mesmos entre si e nas causas desse conflito. A antitética transcendental é uma investigação sobre a antinomia da razão pura, de suas causas e do seu resultado. Quando não nos limitamos a aplicar a nossa razão, no uso dos princípios do entendimento, aos objetos da experiência, mas ousamos alargar esses princípios para além dos limites desta experiência, surgem teses sofísticas, que da experiência não têm a esperar confirmação, nem refutação a temer, e cada uma delas não somente não encerra contradição consigo própria, mas encontra mesmo na natureza da razão condições da sua necessidade; a proposição contrária, porém, infelizmente, tem por seu lado fundamentos de afirmação válidos $\mathrm{e}$ necessários. 
Kant concebe que estes interesses divergentes poderiam arrastar alguns filósofos a determinar-se, segundo o interesse intelectual de cada um, tanto pelas "teses" quanto pelas “antíteses". Porém tal escolha, por mais justificada que seja nada teria de crítica; cabe à Razão, ela mesma, o elucidar o que se pode chamar de antinomias. A Razão poderia solucionar as antinomias? Kant nos responde que sim. Pois, os dados que constituem o problema das antinomias estão todos eles na mente humana. A origem da antinomia não estaria na experiência enquanto tal, porém no uso a priori que da experiência fazemos, nos ensina Kant. A solução para o enfrentamento deste problema, ou seja, da antinomia, estaria numa atitude racional, que Kant classificou de muito simples a "atitude cética". Pois, se os raciocínios cosmológicos trazem no seu âmago manifestas contradições, fica evidente, claro, que as idéias transcendentais que as fundamentam perdem totalmente sua faculdade especulativa, qual seria o motivo racional que nos remeteria a especular com conceitos vazios e imaginários. A atitude cética proposta por Kant é simples e coloca as questões acima aludidas em muito bom caminho, embora haja outros dentro daquilo que o filósofo denominou de "idealismo crítico", que não é objeto de reflexão desta Tese. Como seria esta "atitude cética, ou seria, o método cético"? Kant (1994: 389-390) assim se pronuncia:

O método (grifo nosso) de assistir a um conflito de afirmações, ou antes, de o provocar, não para se pronunciar no fim a favor de uma ou outra parte, mas para investigar se o objeto da disputa não será mera ilusão, que qualquer delas persegue e com a qual nada ganharia, mesmo que não encontrasse resistência, tal modo de proceder, digo, é o que se pode denominar de método cético. É totalmente diferente do ceticismo, princípio de uma ignorância artificial e científica, que mina os fundamentos de todo o conhecimento para, se possível, não deixar em parte alguma confiança ou segurança. Com efeito, o método cético aspira à certeza e procura o ponto de dissídio numa controvérsia bem intencionada e conduzida com inteligência, para fazer como esses sábios legisladores que, em face das perplexidades dos juízos nos processos, colhiam ensinamentos quanto ao que era deficiente ou insuficiente em suas leis. A antinomia que se manifesta na aplicação das leis é, na nossa limitada sabedoria, a melhor pedra de toque da nomotética, mercê da qual a razão, que na especulação abstrata não se apercebe facilmente dos seus passos em falso, se tornará mais atenta aos momentos da determinação dos seus princípios.

Kant define que este método cético seria muito apropriado à Filosofia Transcendental, não cabendo sua aplicação as matemáticas, pois nestas, não podem se esconder proposições falsas, já que, nas matemáticas há a exigência da demonstração e estas advêm sempre de um caminho da intuição pura. Este método poderia auxiliar em outras ciências, que tenham por fulcro o permitir-se uma livre e desimpedida competição entre as idéias. Para Kant (1994: 
447) a antinomia da razão pura desaparece nas idéias cosmológicas desde que se mostrou apenas dialética. Na referida página nos diz o filósofo:

A Dialética Transcendental não favorece, pois, de modo algum, o ceticismo, mas sim o método cético, que nela dá mostras da sua grande utilidade, quando se defrontam na máxima liberdade os argumentos da razão, que, embora nos não proporcionem por fim o que se procurava, oferecem, todavia algo sempre útil e que poderá servir para retificar os nossos juízos.

Para Kant, "todo o conhecimento humano começa por intuições, daí passa a conceitos e termina com idéias", enunciado este, presente na Crítica da Razão Pura (1994: 570).

A Doutrina Transcendental do Método, último livro da Crítica da Razão Pura é o texto onde o filósofo aborda o conjunto de todo o conhecimento humano, advindo da Razão pura, enquanto especulativa, capaz de perscrutar o mundo, perceber e ter apercepção do fenômeno, das coisas, do ser enquanto essência e existência chegando então ao númeno. Compara o filósofo tal desiderato à construção de um edifício, do qual temos pelo menos a idéia de como seria o mesmo. Fazendo então, uma autocrítica sobre o risco que corre quem tem tal pretensão, pois no meio do caminho podem faltar material, os operários podem não se entender devido à confusão das línguas e, assim, do projeto que se pretendia ser, uma torre para atingir o céu, o filósofo se resignou, resistiu à possibilidade de desistir da empreitada e construiu uma "habitação sólida e necessária", com os "materiais" que tinha à mão. Kant (1994: 575-576) nos ensina:

Entendo assim por doutrina transcendental do método (grifo nosso) a determinação das condições formais de um sistema completo da razão pura. Neste propósito, teremos que nos ocupar de uma disciplina, de um cânone, de uma arquitetônica e, finalmente, de uma história da razão pura e realizar de um ponto de vista transcendental aquilo que, com o nome de lógica prática, relativamente ao uso do entendimento, era tentado nas escolas, mas mal executado, pois não estando à lógica geral limitada a nenhuma espécie particular do conhecimento intelectual (por exemplo, ao conhecimento puro), nem tão pouco a nenhum objeto particular, não pode, sem ir buscar conhecimentos em outras ciências, fazer mais do que propor títulos para métodos possíveis, e expressões técnicas de que nos serviremos em relação ao que há de sistemático em todas as ciências e que dão a conhecer antecipadamente ao aprendiz nomes, cujo significado e utilização só mais tarde deverá conhecer.

Kant (1994: 577) ao relatar uma "disciplina da Razão Pura", demonstra o problema metódico dos denominados "juízos negativos”, que “(...) não o são tão somente do ponto de vista da forma lógica, mas também do ponto de vista do conteúdo, não gozam de nenhum 
apreço especial da parte do desejo de saber que têm os homens", segundo o filósofo haveria a necessidade de um grande esforço para tolerarmos tais "juízos” e propiciar-lhes "estima e favor". Kant nos ensina na mesma página que:

É certo que se podem exprimir, logicamente, todas as proposições sob a forma negativa; mas, em relação ao conteúdo do nosso conhecimento em geral, têm as proposições negativas a função própria de impedir simplesmente o erro. Assim, as proposições negativas, que devem prevenir um falso conhecimento, onde, contudo nunca é possível um erro, são verdadeiras, mas vazias, isto é, não são adequadas à sua finalidade e, por isso, são muitas vezes ridículas, como a proposição desse retórico, que afirmava que Alexandre não poderia ter feito conquistas sem exército. Mas onde os limites do nosso conhecimento possível são muito estreitos, grande a inclinação para julgar, a aparência que se oferece muito enganadora, e considerável o dano proveniente do erro, o caráter negativo de uma instrução, que unicamente serve para nos preservar do erro, tem ainda mais importância que muito ensinamento positivo pelo qual o nosso conhecimento poderia aumentar.

Ensina-nos ainda Kant que a "coação" enquanto ato que nos impede paulatinamente do "desviar-nos" de certas regras, até que estes desvios sejam "extirpados", o filósofo chama de disciplina, que seria diferente de cultura, devendo proporcionar uma aptidão, de tal forma que não destrua "uma outra já existente". O filósofo nos ensina na mesma página aludida acima que: "Para a formação de um talento, que já por si mesmo tem uma propensão para se manifestar, a disciplina dará um contributo negativo (Kant nos alerta que o termo disciplina aqui usado não se deve confundir como sinônimo de ensinamento, como pretendido em algumas escolas), mas a cultura e a doutrina (grifos nossos) contribuirão positivamente.”

$\mathrm{Na}$ doutrina transcendental do método, onde se exige uma disciplina, um cânone $e$ uma arquitetônica, Kant ensina que a disciplina deve ser tratada tanto para o "uso dogmático" quanto para o seu "uso polêmico, como em "relação às hipóteses", como também em "relação às suas demonstrações", tem como desiderato o refletir-se como a Razão Pura se manifesta através de um método que a faça permanecer mesmo naquelas condições em que a dúvida permeia o nosso pensar. Kant (1994: 578) nos ensina:

Que o temperamento, assim como as disposições naturais, que de bom grado se permitem um movimento livre e ilimitado (como imaginação e agudeza de espírito), necessite em muitos aspectos de uma disciplina, toda gente admite facilmente. Mas que a razão, que tem por obrigação própria prescrever a sua disciplina a todas as outras tendências, tenha ela própria ainda necessidade de uma, pode parecer estranho. E, de fato, escapou até hoje a uma semelhante humilhação, precisamente porque, devido ao ar 
solene e às maneiras imponentes como que se movimenta, ninguém podia facilmente suspeitá-la de um jogo frívolo, com imagens em lugar de conceitos e palavras em vez de coisas. Não é necessária uma crítica da razão no uso empírico, porque os seus princípios estão submetidos continuamente à prova da experiência, que lhe serve de pedra de toque; nem também na matemática, onde os conceitos devem estar imediatamente presentes in concreto na intuição pura e, desse modo, imediatamente se revela tudo o que não é fundamentado e é arbitrário. Mas onde nem a intuição empírica nem a intuição pura mantêm a razão num caminho bem visível, a saber, no seu uso transcendental, em que procede por simples conceitos, torna-se tão necessária uma disciplina, que reprima a sua tendência a estender-se para além dos estreitos limites da experiência possível e a mantenha longe de todo o excesso e de todo o erro, que toda a filosofia da razão pura não tem outro objetivo a não ser esta utilidade negativa.

A disciplina no seu uso dogmático é tratada pelo filósofo de forma "metódica", deixando-se bem claro o seu desiderato. Refere-se esta forma metódica a um modo comparativo entre a Filosofia enquanto ciência primeira e a Matemática enquanto representante maior das ciências. Para Kant (1994: 580) "O conhecimento filosófico é o conhecimento racional por conceitos, o conhecimento matemático, por construção de conceitos". Construir conceitos enquanto significa o "apresentar a priori a intuição que lhe corresponde". Kant nos ensina, na mesma página, que na construção de um conceito seria exigido uma "intuição não empírica que, conseqüentemente, como intuição é um objeto singular, mas como construção de um conceito, nem por isso deve deixar de exprimir qualquer coisa que valha universalmente na representação, para todas as intuições possíveis que pertencem ao mesmo conceito". Pode-se evidentemente perceber nestas proposições kantianas tanto um método, quanto uma estrutura (aqui no sentido piagetiano do termo).

E) O Método dialético em Piaget. A superação das contradições na leitura da experiência e a justificativa teórica para o levantamento da "hipótese rival". $O$ duplo uso da Razão no processo da abstração reflexiva

O Método, essencialmente dialético, em Piaget, no sentido de caminho ou procedimento para se chegar a um fim, é o próprio raciocínio, o pensamento racional natural, determinado pelo funcionamento endógeno, funcionamento das estruturas mentais orgânicas, específicas para o ato de conhecer. O grande problema nessa concepção é o trazer para a consciência esse funcionamento e poder aplicá-lo ao mundo empírico na busca de um conhecimento científico. 
Essa busca realizada pelo pensamento natural racional consiste essencialmente em superar o jogo das contradições entre as afirmações e negações: o "é isso" e o "não é isso", ou seja, o afirmar 'a' como sendo 'b' e ao mesmo tempo negar 'a' como sendo 'b'. Criando assim uma contradição. Claro está que na prática as coisas revelam-se de maneira camuflada: "tudo indica que a vítima morreu intoxicada pelo gás do ar condicionado, mas ao mesmo tempo a quantidade de gás exalado pelo ar condicionado não teria capacidade de matar". Considere-se ainda, afirmações, como as que relataremos a seguir encontradas em diversos documentos médicos e médico-legais, veja-se o "jogo de contradições" ali instaladas: afirmar-se de início ação vulnerante contundente e lesão corto - contusa como conseqüência; afirmar-se "paciente corado em linha acima e na linha abaixo", "palidez cutânea"; paciente "eupnéico" em linha anterior e na mesma página "paciente apresenta expansibilidade torácica diminuída”.

Uma primeira forma de contradição consiste em oposição entre ações, no entender de Piaget. Quando as possíveis ações são simples, as contradições praticamente inexistem. Mas desde que essas se tornam complexas e se trate de organizá-las (intervindo aí o aspecto previsão), as contradições tornam-se evidentes.

As contradições surgem, sempre de acordo com Piaget, porque o sujeito do conhecimento despreza sempre as negações, ou seja, a hipótese de situações ou fatores negativos concomitantes às afirmações. Todas as ações por mais claras que pareçam devem ser solidárias de dois sistemas de negações, um externo: o mesmo fim pode ser alcançado por ações diferentes; e outro interno: saber da possibilidade de uma ação, ainda que intencional, não alcançar o fim determinado a partir de sua origem. Daí a base teórica fundamental para a importância da "hipótese rival".

A contradição permanece quando as coordenações das ações e ou de suas representações não estão completas dentro do sistema considerado.

Ora, é o ultrapassamento da contradição que faz progredir o conhecimento por intermédio da construção que repousa sobre a abstração reflexiva e devemos entendê-la como uma contradição dialética. Diz Piaget em Recherches sur la contradiction, (1974: vol. II, à página 176): 
Quant aux contradictions dialectiques, bornons nous à rapeller que la pensée naturelle, étant essentiellement dialectique en son dévellopement, en tant que sucession de desequilibres et de rééquilibrations, elles ne sauraient que relever de tels mécanismes à condition de se rappeler que ces contradictions "dialectiques" comme naturelles, ne sont que l'expression et non pas la source de ces déséquilibres.

Tradução livre:

Quanto às contradições dialéticas, limitemo-nos a lembrar que o pensamento natural, sendo essencialmente dialético no seu desenvolvimento, enquanto sucessão de desequilíbrios e de reequilibrações, elas (contradições dialéticas) só poderiam por em relevo tais mecanismos, com a condição de que nos lembremos que estas contradições dialéticas enquanto naturais, são a expressão e não a origem dos desequilíbrios.

Pensar sobre dados empíricos e sobre relações são coisas diferentes, como, aliás, já dizia Kant com o seu conceito anfibolia. Anfibolia que Kant (1994: 279-280) nos ensina com o seguinte texto:

Os conceitos podem ser comparados, logicamente, sem cuidar de saber a que
lugar pertencem os seus objetos, se, como númenos, ao entendimento ou
como fenômenos, à sensibilidade. Se, porém, com estes conceitos, queremos
chegar aos objetos, é antes de tudo necessária uma reflexão transcendental,
para saber a faculdade de conhecimento de que devem ser objetos, se o
entendimento puro ou a sensibilidade. Sem esta reflexão, faremos um uso
muito inseguro destes conceitos, originando-se pretensos princípios
sintéticos que a razão crítica não pode reconhecer e que, por fim, assentam
simplesmente numa anfibolia transcendental (grifo nosso), isto é, numa
confusão entre o objeto futuro do entendimento e o fenômeno.

Piaget comenta que essa distinção é essencial, mas que é evidente que não se trata de duas "razões", mas duas atitudes ou dois métodos da Razão quando essa se aplica ao mundo empírico e quando procede por abstração reflexiva, que seria o pensar sobre o dado da experiência e não simplesmente constatar. Pensar sobre o dado empírico é inseri-lo num sistema de relações pré-existentes. É graças a essa reflexão que pode haver os ultrapassamentos dialéticos. Quem lançou esse modelo foi Kant, diz Piaget, e como, aliás, demonstramos acima. Piaget comenta ainda que Kant distingue as "contradições de fato" ou contradições reais, das que seriam as pensadas, as representadas. Piaget (2003: 106) nos ensina:

No domínio das estruturas lógico-matemáticas, sendo dada uma estrutura, quase que se tornou um método (grifo nosso) procurar construir, por um sistema de negações, os sistemas complementares ou diferentes que se poderão, em seguida, reunir em uma estrutura complexa total. Até a própria negação foi assim negada na "lógica sem negação" de Griss. Por outro lado, quando se trata de determinar se um sistema é A que ocasiona B, ou o inverso, como nas relações entre ordinais e cardinais finitos, entre o conceito e o juízo etc., pode estar certo de que às prioridades ou filiações lineares sempre acabarão por seguir-se interações ou círculos dialéticos. No terreno das ciências físicas e biológicas a situação é comparável, ainda que derivando daquilo que Kant denominava "as contradições reais" ou de fato: é 
necessário lembrar as oscilações entre os pontos de vista corpusculares e ondulatórios nas teorias da luz, as reciprocidades introduzidas por Maxwell entre os processos elétricos e magnéticos etc.? Nesses domínios, como no das estruturas abstratas, parece, pois, que a atitude dialética constitui um aspecto essencial da elaboração das estruturas, aspecto, ao mesmo tempo, complementar e indissociável da análise, mesmo formalizadora: essa "qualquer coisa a mais" que Leví-Strauss parcimoniosamente lhe concede consiste, portanto, em muito mais que um lançamento de "passadiços" e volta, sem dúvida, a substituir os modelos lineares ou em árvores pelas famosas "espirais" (como a dupla hélice do DNA, comentário nosso) ou círculos não viciosos, tão de perto aparentados aos círculos genéticos ou interações próprias aos processos de desenvolvimentos.

As abstrações empíricas são como uma espécie de reprodução mental do que foi visto, do que foi constatado, ao passo que as abstrações reflexivas são muito mais que isso, dizem respeito à inserção do que foi visto em vários sistemas de relações que podem estar inicialmente separados, mas que por intermédio dos dados novos, constatados e refletidos, representados, passam a estar relacionados. Estabelecem-se então as relações entre os novos dados e os sistemas pré-existentes. Assim, a abstração reflexiva permite a superação de contradições surgidas na empiria, graças à simples constatação. A abstração empírica está muito próxima da assimilação puramente orgânica, como a assimilação dos alimentos na digestão.

O que se pode chamar de assimilação de alimentos na digestão e que estaria tão próxima da "abstração empírica" no dizer de Piaget? Ora, a assimilação é a incorporação de nutrientes ao protoplasma. Ensina-nos Maffei (1978:201): “(...) incorporados ao protoplasma estes nutrientes, resulta por conseqüência a formação de substâncias específicas para cada tipo de célula que caracteriza o respectivo tecido, pois os protoplasmas não são iguais uns aos outros. (...) por outro lado, o próprio protoplasma elimina os produtos resultantes do seu desgaste ou da modificação das substâncias nele introduzidas”. Continua a nos ensinar Maffei (1978: 201):

Deste modo, os protoplasmas são a sede constante de combinações e desintegrações, isto é, sínteses e análises que, sem destruir-se, determinam permanente circulação de matéria. Esses fenômenos são absolutamente específicos não só para cada espécie animal ou vegetal, como também para cada indivíduo dentro de cada espécie, constituindo a característica da vida e neles residindo o segredo da hereditariedade. Assim a matéria viva novamente formada em cada espécie e em cada indivíduo da mesma espécie é diferente das outras espécies e dos outros indivíduos da mesma espécie não só na sua estrutura, como também na sua composição química e funções, 
porquanto as células dos tecidos de cada espécie formam por si mesmas as substâncias específicas do seu protoplasma, mesmo sendo todos os tecidos nutridos pelo mesmo plasma. Portanto, esta especificidade é de natureza bioquimicogenética, realizando-se por meio das enzimas intracelulares. Por isso, a célula não se nutre somente pelo fato do alimento estar presente, mas sim pelas suas necessidades e possibilidades (grifo nosso).

Se assim podemos descrever a assimilação orgânica, semelhante à assimilação empírica, muito diferente é aquela dos processos cerebrais ou, da aquisição do conhecimento no entender de Piaget (1958: 108)

En bref, affirmer la nécessité de l' assimilation c' est d'abord soutenir que connaitre un objet revient toujours à agir sur lui, matériellement ou opératoirement. L'analyse de telles actions et de leur schématisme conduit alors aux conséquences suivantes. D'une part, il ne saurait exister d'action adaptée sans une coordination des actions entre elles et ce sont les schèmes correspondant à ces coordinations générales qui constituent le point de départ des connaissances logi-comathématiques, susceptibles de fonctionner tôt ou tard à l'état «pur»dans la mesure où elles sont précisément abstraites des coordinations de l'action et non pas de l'objet comme tel. D'autre part et réciproquement, la connaissance des objets suppose des actions différenciées (ou "accommodées » au détail de ces objets), mais, par le fait que ces actions différenciées sont en même temps coordonnées, l'assimilation de l'objet à l'action comporte nécessairement une assimilation du donné expérimental aux schèmes logico-mathématiques inhérents à cette coordination elle-même. Telle est, au total, la signification de l'hypothèse de l'assimilation.

Tradução livre: Resumindo, afirmar a necessidade da assimilação é, antes de mais nada, afirmar que conhecer um objeto significa agir sobre ele, materialmente ou operatoriamente (raciocinando sobre ele). A análise de tais ações (práticas ou mentais) e de seu esquematismo conduz então às conseqüências seguintes. De um lado não poderia existir ação adaptada (que leva ao conhecimento) sem uma coordenação das ações entre elas; e são os esquemas correspondentes a essas coordenações gerais que constituem o ponto de partida dos conhecimentos lógico-matemáticos, susceptíveis de funcionarem cedo ou tarde em estado "puro", na medida em que eles são abstraídos das coordenações da ação e não do objeto como tal. De outro lado e reciprocamente, o conhecimento dos objetos supõe ações diferenciadas (ou "acomodadas" ao detalhe desses objetos), mas, pelo fato de que essas ações diferenciadas são ao mesmo tempo coordenadas, pois a assimilação do objeto à ação comporta necessariamente uma assimilação do dado experimental aos esquemas lógico-matemáticos inerentes à essa mesma coordenação. Tal é, no conjunto, a significação da hipótese da assimilação. [ou seja, do conhecimento enquanto assimilação do dado às estruturas lógico-matemáticas do sujeito, ou seja, às categorias do Entendimento] 
A abstração reflexiva busca razões para os acontecimentos ou fatos observados. Diz Piaget, (1977: 323):

(...) l'abstraction réfléchissant en vient à dégager les raisons intrinsèques des coordinations qu'elle reconstruit et élargit lors des réfléchissements, elle aboutit à ce résultat remarcable qu'un nouveau produit de la réflexion ne saurait contredire les précédents.

Tradução livre: (...) a abstração reflexiva chega a identificar as razões intrínsecas das coordenações que ela reconstrói e amplia no ato das reflexões, ela chega a um notável resultado, ou seja, de que um novo produto da reflexão não poderia contradizer os precedentes.

Porque não poderia contradizer os precedentes? Porque os sistemas pré-existentes formam sistemas de relações coerentes entre si, e é a esses sistemas que o dado novo é lógicomatematicamente assimilado. É justamente por isso que as contradições da empiria e das abstrações empíricas, nesse nível, podem ser superadas. A esse processo de superação de contradições, Piaget dá o nome de Dialética.

Os sistemas lógico-matemáticos construídos graças às abstrações reflexivas são praticamente infinitos ou "abertos" porque cada etapa de construção desses sistemas dá origem a uma próxima abstração que por sua vez origina outra.

Porque, ou, como? Porque os sistemas que vão sendo criados, transformam-se automaticamente em novas formas capazes de assimilar novos conteúdos. (as ações da empiria não são da mesma natureza de suas representações “conceitualizadas", os conceitos exigem uma reconstrução).

Nós assistimos então a um processo em espiral: toda "reflexão" de conteúdos (observáveis na empiria) supõe a intervenção de uma forma (reflexão) e os conteúdos sucessivos assim transferidos para um plano superior, o do pensamento racional, exigem sempre a construção de novas formas devidas a cada reflexão seguinte que implica o "réfléchissement", ou seja, o ato em si do passar da empiria para o mundo da reflexão.

Assim os vários conteúdos transferidos para o pensamento que pensa relações abstratas exigem a construção de novas formas que constituem a própria possibilidade de reflexão. 
Temos então uma alternância ininterrupta de conteúdos $\rightarrow$ formas $\rightarrow$ conteúdos reelaborados $\rightarrow$ novas formas de domínios mais amplos, sem fim nem, sobretudo, de começo absoluto. O próprio dessa espiral é assim, o de alcançar formas cada vez mais ricas e conseqüentemente mais importantes em relação aos conteúdos já que são por intermédio delas que eles são assimilados. De outro lado a riqueza crescente das formas determina um refinamento progressivo das abstrações empíricas porque o cérebro humano está munido de novos instrumentos de assimilação, e os objetos da empiria são cada vez mais, revestidos de propriedades cada vez mais numerosas, introduzidas pela reflexão do sujeito pensante que pensa relações já afastadas dos fenômenos.

Em suma, o desenvolvimento da abstração reflexiva determina sempre a construção de mais formas em relação aos conteúdos, essas formas podendo dar origem, seja a sistemas lógico-matemáticos seja às aplicações aos objetos e às conexões entre eles, no que consistem as explicações causais em Física e na Biologia, em nosso caso, na Medicina Legal.

Piaget (2003: 103-105) ao abordar o Estruturalismo e a Dialética nos ensina que:

É natural, portanto, e bastante instrutivo para nós, ver Lévi-Strauss consagrar quase todo o último capítulo de La pensée sauvage a uma discussão da Critique de raison dialectique de Jean Paul Sartre; um exame desse debate nos parece, com maior razão, indicado aqui, pois um e outro de seus protagonistas parecem ter esquecido o fato fundamental de que no terreno das próprias ciências o estruturalismo sempre foi solidário de um construtivismo, ao qual não se poderia recusar o caráter dialético, com seus sinais distintivos de desenvolvimentos históricos, de oposição de contrários e de "superações", sem falar na idéia de totalidade, comum às tendências dialéticas tanto como estruturalistas. (...) Todavia, não é forçar as palavras dizer que essa complementaridade, segundo a qual "a razão dialética não é outra coisa que a razão analítica, porém, alguma coisa a mais na razão analítica" (La pensée sauvage, p. 326), equivale, aproximadamente, em atribuir simplesmente à primeira as funções de invenção ou de progresso que faltam à segunda, reservando para esta o essencial da verificação. Sem dúvida, essa distinção é essencial e, sem dúvida também, não existem duas razões e sim duas atitudes ou duas espécies de "métodos" (no sentido cartesiano do termo) que a razão pode adotar. Porém, a construção que a atitude dialética reclama não consiste apenas em "lançar passadiços" sobre o abismo de nossa ignorância, cuja margem oposta se afasta continuamente (p.325): esta construção supõe, de qualquer forma, mais, porque é freqüentemente ela própria que engendra as negações, em solidariedade com as afirmações, para encontrar, em seguida, a coerência em uma superação comum. 
Retornando-se à Doutrina transcendental do Método em Kant, embora, de forma sumária, poder-se-ia fundamentar devidamente o pensar humano enquanto segue um "método", uma "via", um "caminho", optar por um deles, visando resolver as aporias apresentadas. No entanto, antes de abordarmos o método, sob a ótica de Kant, seria de bom alvitre rever na Dialética kantiana o que o filósofo chama de "Interesse da Razão, neste conflito consigo própria", já que as vias dentre as quais podemos optar são muitas. Ensina-nos Kant (1994: 426-427-428):

A razão humana é, por natureza, arquitetônica, isto é, considera todos os conhecimentos como pertencentes a um sistema possível, e, por conseguinte, só admite princípios que, pelo menos, não impeçam qualquer conhecimento dado de coexistir com outros num sistema. As proposições da antítese, porém, são de tal natureza que impossibilitam totalmente a construção completa de um edifício de conhecimentos. Segundo elas, acima de um estado do mundo há sempre ainda outro mais antigo; em cada parte, há outras por sua vez divisíveis; antes de qualquer acontecimento há outro, por seu turno produzido por outro; enfim, na existência em geral, tudo é sempre condicionado, sem que se reconheça qualquer existência incondicionada e primeira. Visto a antítese não admitir, em parte alguma, qualquer primeiro termo e um começo que possa servir para fundamento absoluto de uma construção, é fatalmente impossível um edifício completo do conhecimento com tais pressupostos. Eis porque o interesse arquitetônico da razão (que exige não uma unidade empírica, mas uma unidade racional pura a priori) comporta, naturalmente, uma recomendação a favor das afirmações da tese. (...) Querer resolver todos os problemas e responder a todas as interrogações seria atrevida falácia e presunção tão extravagante, que isso bastaria para se tornar imediatamente indigno de toda a confiança. Não obstante, ciências há, cuja natureza é tal, que toda interrogação que nelas se apresenta deve absolutamente poder ser resolvida a partir do que se sabe, pois a resposta deve brotar das mesmas fontes em que nasce a interrogação. Nessas ciências não é lícito pretextar uma ignorância inevitável, mas, pelo contrário, pode exigir-se uma solução. $O$ que seja justo ou injusto, em todos os casos possíveis, deverá saber-se segundo a regra, porque diz respeito à nossa obrigação e não somos obrigados relativamente àquilo que não podemos saber. (grifo nosso).

O cenário de incertezas que permeia a ciência (sensu lato) na hodiernidade é bem ressaltado no texto inicial desta citação kantiana quando o filósofo fala na sua Dialética, sobre as antinomias, os paralogismos e a respeito da díade Tese/Antítese. Díade esta, fundamento da dialética moderna, mas que já existia desde a dialética platônica.

O parágrafo final da mesma citação, no entanto, serve como uma luva aos objetivos e desideratos da Medicina Legal. Pois, nesta ciência, o entendimento dos fenômenos por ela observados e tratados, deve ser alcançado por intermédio de um "método dialético" que 
forme sistemas. Pois naquilo em que há a necessidade de contemplar-se a universalidade dos fundamentos, a metodologia a ser aplicada, deve ser dialética, devido à amplitude dos seus atributos, só em casos muito específicos, muito particulares, no cotidiano do agir pericial, quando a abordagem é singular, urge a demonstração, daí o caráter apodítico do referido agir. Exemplo: houve estupro ou não.

Tendo como fundamento o que bem afirma Kant no texto acima, é de se perceber que numa ciência como a Medicina Legal, a resposta aos questionamentos encontra-se no mesmo território das indagações, ou seja, ambos no corpo humano. Não se pode, no agir pericial, alegar ignorância em relação aos fenômenos ou casos estudados, antes, é dever apresentar laudos, baseados na demonstração apodítica, portanto, necessária. Por fim ao operador da Medicina Legal não pode ser imputado ônus daquilo que ele não sabe ou não lhe foi informado.

Kant ensina sobre o uso "dogmático" da disciplina da Razão Pura, após as reflexões gerais sobre o tema e já aludido acima. Começa por abordar o referido tópico a partir das seqüências lógicas, onde se pode aprender sobre a "disciplina" que leva às definições, aos axiomas na matemática, definições e demonstrações, em qualquer ciência, diríamos nós. Kant (1994: 589) assim trata das referidas "definições":

Como a própria expressão indica, definir não deve significar propriamente, mais do que apresentar originariamente o conceito pormenorizado de uma coisa dentro dos seus limites. (O pormenor significa a clareza e a suficiência dos caracteres, os limites, a precisão, de tal maneira que não haja mais caracteres do que os que pertencem ao conceito pormenorizado). Segundo tal exigência, um conceito empírico não pode ser definido, mas apenas explicitado. Com efeito, uma vez que temos nele apenas alguns caracteres de certa espécie de objetos dos sentidos, nunca é seguro se, pela palavra que designa o mesmo objeto, não se pensam uma vez mais caracteres desse objeto, outra vez menos.

O fecho desta sequiência é feito por Kant quando o filósofo fala das demonstrações à página 593:

Só uma prova apodítica (grifo nosso), na medida em que é intuitiva, podese chamar demonstração (grifo nosso). A experiência certamente nos ensina aquilo que é, mas não que não possa ser de outra maneira. Por isso, princípios empíricos não podem dar-nos qualquer prova apodítica. De conceitos a priori (no conhecimento discursivo) nunca pode resultar certeza intuitiva, isto é, evidência, por mais que o juízo possa ser apoditicamente certo. Só a matemática, portanto, contém demonstrações, porque não deriva 
de conceitos o seu conhecimento, mas da construção de conceitos, isto é, da intuição que pode ser dada a priori em correspondência aos conceitos.

Na Medicina Legal, considerada como ciência oriunda de a empiria, as definições e as demonstrações, enquanto apanágio da disciplina no sentido kantiano do termo e referenciado acima, merece uma consideração especial. As definições são o próprio centro da atividade pericial, posto que, este agir deve ser representado por texto escrito, que tem como objetivo o servir de prova, na ambiência processual do Direito enquanto meio para se buscar a Justiça. Kant nos fala da impossibilidade de se definir algo na empiria, porque, por mais que se tenham caracteres pormenorizados deste algo, há a concreta possibilidade de não se terem todos os caracteres. Devido a esta situação o filósofo entende que se deva designar e não definir. Pois, na designação tolera-se a não totalidade dos caracteres próprios de cada coisa. No entanto, a prova pericial, em que pese à possibilidade de ser falseada no sentido popperiano do termo, necessita de uma verificação tão completa, atendendo ao repto cartesiano de "fazer-se verificações e observações tão completas que não se permita a omissão de nenhum elemento". É obvio que esta proposição cartesiana ideal, não é conseguida em não poucas vezes, o que remete aos organismos e instituições responsáveis pela formação destes peritos ainda uma maior responsabilidade. Deve-se, portanto, buscar as definições, não sendo possível devido a problemas estruturais e de formação teórica e técnica, deve-se ao menos designar-se cada evento com o maior número de elementos possíveis.

A Medicina Legal enquanto ciência oriunda da empiria, portanto, onde também se aborda o conhecimento racional por "construção de conceitos", não trata do universal e do necessário, como ocorre nas matemáticas, mas trata do freqüente, ou seja, daquilo que

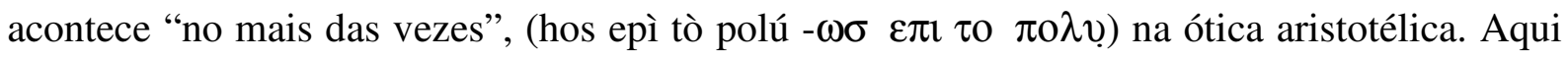
também se faz ciência, pois o caráter de "necessário" está presente, em "no mais das vezes"; como referido em texto acima, pois ocorre em alguns fatos, mas não em todos. Entendo que é tarefa difícil uma formalização em Medicina Legal, porém a mesma não é impossível, desde que dela se tire o caráter metafísico como bem refere Popper. Uma formalização seria possível, pois o freqüente aristotélico, (que “como a teoria das probabilidades reintroduz de certa forma, o desviante, mas somente enquanto representativo de uma classe, e não como individual", como diz Granger, em texto já devidamente citado.) estabelece conjuntos doutrinários e sistemas de referência que tornam possível dizer-se da cientificidade da sua prática. 
Quanto às "demonstrações", enquanto expressão de uma prova apodítica, entendemos que tanto pensando em Kant quanto em Aristóteles o "demonstrar-se" através da prova é o objetivo da Medicina Legal, enquanto ciência com forte impacto social.

Quanto à disciplina da Razão Pura relativamente ao seu uso polêmico, Kant (1994: 596) nos ensina que:

Em todos os seus empreendimentos deve a razão submeter-se à crítica e não pode fazer qualquer ataque à liberdade desta, sem se prejudicar a si mesma e atrair sobre si uma suspeita desfavorável. Nada há de tão importante, com respeito à utilidade, nem nada de tão sagrado que possa furtar-se a esta investigação aprofundada que não faz exceção para ninguém. É mesmo sobre esta liberdade que repousa a existência da razão; esta não tem autoridade ditatorial alguma, mas a sua decisão outra coisa não é que o acordo de cidadãos livres, cada um dos quais deve poder exprimir as suas reservas e mesmo exercer o seu veto sem impedimentos. Ora, se bem que a razão nunca possa furtar-se à crítica, também não tem sempre motivo para temê-la.

Kant (1994: 615) ao se referir à disciplina da Razão Pura em relação às hipóteses, (hipóteses estas tão importantes na ambiência científica) o faz da seguinte maneira:

Para que a imaginação não devaneie, mas conjecture debaixo de rigorosa vigilância da razão é sempre necessário que se apóie previamente sobre qualquer coisa de absolutamente certo e não imaginário ou de simples opinião. Essa qualquer coisa é a possibilidade do próprio objeto. Então é permitido, pelo que respeita á realidade desse objeto, recorrer à opinião; mas esta opinião, para não ser sem fundamento, deve estar ligada, como princípio de explicação, ao que é realmente dado e, portanto certo, e neste caso chama-se hipótese.

A doutrina transcendental do método, textos, onde Kant faz o devido acabamento da Crítica da Razão Pura, comporta além da disciplina que comentamos de forma sumária, trata também de um cânone e ainda de uma arquitetônica. Tópicos estes que também abordaremos sumariamente, pois o que deve prevalecer enquanto proposta desta Tese é o método dialético que entendemos seja mais adequado a uma abordagem científica na ambiência da Medicina Legal. Para Lalande (1999: 133) o termo cânone significa: "regra prática, norma, modelo a seguir"; em Kant (1994: 634) o mesmo termo significa: “O conjunto dos princípios a priori do uso legítimo de certas faculdades cognitivas em geral”.

O filósofo continua, na mesma página, a apontar um rol de faculdades onde a presença de um cânone é evidente, senão, veja-se: 
Assim a lógica geral, na sua parte analítica, é um cânone para o entendimento e para a razão em geral, mas apenas quanto à forma, pois abstrai todo o conteúdo. Assim, a Analítica transcendental é o cânone do entendimento puro, pois este último é o único capaz de verdadeiros conhecimentos sintéticos a priori. Onde, porém, não é possível nenhum uso legítimo de uma faculdade cognitiva não há cânone. Ora, todo o conhecimento sintético da razão pura, no seu uso especulativo, conforme todas as provas apresentadas até aqui, é completamente impossível. Portanto, não há nenhum cânone do uso especulativo da razão (pois este uso é completamente dialético) e toda a lógica transcendental é, neste ponto de vista, apenas disciplina. Por conseqüência, se há em qualquer parte um uso legítimo da razão pura, deve existir nesse caso um cânone dessa razão, e este não deverá ser relativo ao uso especulativo, mas ao uso prático da razão.

Os fundamentos de cada um dos tópicos que compõem o universo da Medicina Legal, já referenciado no capítulo sobre a Doutrina, nesta Tese, trazem no seu âmago conteúdos doutrinários, conceitos, técnicas, que têm todos eles como corolário o seu uso prático. Fundada no trato dos eventos e casos do cotidiano, a Medicina Legal começa respondendo a aquelas "questões" que reclamavam respostas a serem produzidas pelo pensar humano, ou seja, pela Razão humana, esta, enquanto expressão do funcionamento do córtex cerebral. O elenco dos temas tratados por esta ciência ao longo de sua tradição diversas vezes centenária, pela sua magnitude, pela complexidade que lhe é inerente, pela faculdade que o gênio humano teve no trato destes temas, compõe no sentido kantiano do termo um cânone, que se manifesta em cada um dos referidos tópicos, pois em cada um deles, embora diversos na origem, formam um conjunto na sua finalidade, gerando, por conseguinte: normas, regras e modelos.

Para que todo este complexo, diverso e extenso conjunto que forma a Medicina Legal possa cumprir o seu objetivo precípuo, ou seja, produzir a prova científica em busca da Justiça, esta o maior bem da sociedade no dizer de Rawls, é necessário que o seu operador forme ciência, convicção e persuasão, a primeira construída pelo estudo, pela reflexão, pela angustia de evoluir permanentemente (atente-se aqui ao que diz Aristóteles, quando fala do cidadão ideal (Spoudaio), pelo saber transitar da teoria à prática e fundamentalmente, bem interpretar os fenômenos; a segunda, na ótica kantiana, "é um fato do nosso Entendimento que pode repousar sobre princípios objetivos, mas que também exige causas subjetivas (...) quando é válida para todos aqueles que sejam dotados de razão e o seu princípio é objetivamente suficiente, chama-se conviç̧ão"; a terceira, também na ótica kantiana, "se a proposição anterior tem o seu princípio apenas na natureza particular do sujeito designa-se por persuasão". (Kant 1994: 649). 
Em muitas situações este operador da ciência (médico legista) diante de situações específicas da sua prática cotidiana, no uso desta ciência (Medicina Legal), está convicto de algo, de tal fato e pode por conseqüência produzir documentos que levem ao convencimento do julgador; em outras ocasiões devido a diversas situações e obstáculos técnicos e/ou científicos, ele fica apenas persuadido, nestas ocasiões torna-se difícil para ele levar o referido convencimento ao mesmo julgador. Este estado de convicção só é possível se o "método", aliado à "ciência", produzirem uma "arquitetônica” da razão.

O filósofo de Königsberg leva ao término sua Crítica da Razão Pura, com o que ele chamou de "arquitetônica" desta mesma Razão, nas páginas 657 e 658 observe-se o que nos ensina o filósofo:

Por arquitetônica entendo a arte dos sistemas. Como a unidade sistemática é o que converte o conhecimento vulgar em ciência, isto é, transforma um simples agregado desses conhecimentos em sistema, a arquitetônica é, pois, a doutrina do que há de científico no nosso conhecimento em geral e pertence, assim, necessariamente, à metodologia. Sob o domínio da razão não devem os nossos conhecimentos em geral formar uma rapsódia, mas um sistema, e somente deste modo podem apoiar e fomentar os fins essenciais da razão. Ora, por sistema, entendo a unidade de conhecimentos diversos sob uma idéia. Este é o conceito racional da forma de um todo, na medida em que nele se determinam a priori, tanto o âmbito do diverso, como o lugar respectivo das partes. O conceito científico da razão contém assim o fim e a forma do todo que é correspondente a um tal fim.

A Medicina Legal é ciência, já demonstramos ao longo desta Tese. Colocando nosso olhar sobre esta ciência, por diversas vezes centenária, como já o dissemos, tanto na ótica de Aristóteles (que acredita que o conhecimento começa na experiência, mas que seu estabelecimento deve obedecer aos princípios lógicos que ele criou: identidade, terceiro excluído e não-contradição que no fundo identificam-se com aquilo que chamamos condições a priori e que dão espaço ao funcionamento cerebral), quanto na ótica kantiana (quando o filósofo de Königsberg nos diz que: o conhecimento começa sim na experiência, mas dela não deriva) e refletindo-se sobre o texto acima que trata da "arquitetônica da Razão”, podemos afirmar com toda "convicção" que a Medicina Legal nos seus fundamentos, nos seus temas, nas suas técnicas e, sobretudo na sua doutrina é ciência, de acordo com os severos critérios da Filosofia das Ciências. Se a "unidade sistemática" kantiana tem a condição de transformar o "conhecimento vulgar" em "ciência", o que se dizer de um conjunto de temas, tópicos, doutrinas amalgamados por uma idéia, ou seja, fazer do 
conhecimento cujo conteúdo vem da empiria, porém, necessariamente construído com o uso das funções superiores do encéfalo humano, (outrora chamadas funções a priori da Razão), um instrumento eficaz, no orientar as estruturas sociais na consecução da Justiça, quando esta necessitar do concurso da ciência.

O buscar a Justiça, quando há a necessidade de uma ciência como a Medicina Legal, por exemplo, deve ser operacionalizado por um método, o qual ousamos propor então com o nome de Método dialético.

\section{F) Abertura para a proposta de um Novo Método em Medicina Legal}

O Método dialético fundamentado em Kant e Piaget pode ser resumido na seqüência: conteúdos $\rightarrow$ formas $\rightarrow$ conteúdos reelaborados $\rightarrow$ novas formas de domínios mais amplos, sem um fim ou começo determinado. Para Kant e para Piaget como foi referenciado acima, o conteúdo e a forma são constituintes simultâneos do conhecimento, pois aquele é determinável e esta determinante. Esse é o primeiro aspecto, digamos primeira regra do Método que propomos.

Quando se está diante de evento, fenômeno, objeto, que demanda estudo, portanto processo mediato, este é cogente com um "aprofundar-se" na substância, na essência dos mesmos, ab initio submeter cada um deles a método analítico, ou seja, decompô-los, avaliar suas partes e, sobretudo, contemplar os possíveis contrários, ou seja, levantar-se necessariamente a hipótese rival. Esse é o segundo e absolutamente indispensável aspecto, digamos segunda regra do Método

Em seguida viria o terceiro aspecto ou terceira regra do Método, buscar como desiderato a síntese e por consequiência demonstrar, evidenciar, se possível, o seu caráter apodítico, gerar convicção e formular-se finalmente a prova. Buscar-se, portanto, na relação (cópula como conceito da Lógica) da díade "tese/antítese" uma superação das possíveis contradições (ou aporias), ou seja, uma "síntese" dialética e assim de maneira progressiva superar-se a dúvida e chegar-se à "certeza" que teria aqui o caráter de "extrínseca", pois emanaria do conhecimento, autoridade e credibilidade éticas de quem proferiu proposição, conceito, definição etc. 
O agir pericial no âmbito da Medicina Legal que elabora muitas vezes documentos em cuja base há certo automatismo no apreciar-se, perceber-se o caso, objeto, fenômeno, aliás, como foi comprovado em documentos de nossa pesquisa, (onde pode-se ver afirmações e negações do mesmo evento apreciado, dentre outras falhas, gerando contradições, veja-se aqui a importância Lógica, do princípio da não contradição da Lógica Aristotélica), muito ganharia em acurácia, eficácia ao fugir deste automatismo oriundo muitas vezes dos hábitos e crenças geradas na infância. Esse seria o quarto aspecto, ou quarta regra do Método que propomos.

Tal proposta é ainda mais objetiva se levarmos em consideração que no âmbito da Medicina Legal inexiste a possibilidade do imediato, ou seja, daquilo que dispensa a mediação, quando não, pelo simples fato deste agir, embora esteja no presente e tenha por aspiração a aletheia e não o pseudo, pois deve como conseqüência, gerar textos com base no termo latino veritas. Enquanto na consecução do exame pericial, o perito trabalha com o conceito grego de verdade, portanto, no tempo presente e na elaboração do devido documento médico-legal trabalha com o conceito latino de verdade, logo, no tempo passado como referência. Se forem seguidas essas regras, no agir pericial, escaparíamos do indesejável "exame dependente exclusivamente do perito".

Nélio Rojas (1936) chama a atenção em seu livro, referenciado por diversas vezes nesta Tese, para o fato de que "uma necropsia não pode ser repetida"; como num repto que se faz ao médico-legista, que além de agir com acurácia, tem a necessidade de demonstrar e tornar possível a contraprova, atendendo, acreditamos nós, ao "método dialético", o que de outra forma, parece-nos, seria impossível, a não ser pela inteligência pessoal do legista. $\mathrm{O}$ exame que depende exclusivamente do agir e do entendimento de uma única pessoa, peca pela unilateralidade e univocidade como nos ensina Popper (1972: 41), por impedir o "falseamento" e, portanto, não evidenciar "ciência".

$\mathrm{O}$ método dialético, tanto na ótica aristotélica, quanto na ótica kantiana $\mathrm{e}$ sobremaneira em Piaget, permite tratarem-se as díades: "proposição e sua oponente", "tese/antítese", "prova e exame", "análise/síntese", e tantas teses e antíteses quantas possam existir no Entendimento humano. Kant e Piaget nos ensinam e já referenciado acima, que no trato das coisas, pela comparação, inicia-se um processo de avaliação do elemento dado pela análise de uma síntese, que gera nova síntese e na seqüência nova análise e assim, até à 
essência do evento ou coisa, estabelecendo-se então, à qual instância do conhecimento pertencem as coisas observadas e suas representações.

Tendo por objetivo demonstrar (no sentido tanto aristotélico quanto kantiano e piagetiano do termo) que por um método dialético se pode alcançar o desiderato próprio da Medicina Legal, qual seja, na ambiência da ciência, como partícipe desta, produzir prova com fundamentação científica, vejamos como seria o raciocinar do legista enquanto médico, na observação, avaliação e interpretação do caso, objeto, fenômeno.

O médico-legista diante de um evento, leia-se aqui, "quadro clínico", deve levantar uma hipótese, buscar então no arsenal de "observações anteriores, transformadas em representações atuais", portanto, no conjunto de suas experiências vividas, assim como também no conjunto dos sistemas de conceitos aprendidos, chegar a um diagnóstico. No caso da Medicina Legal, a um diagnóstico, por analogia com a Medicina clínica, por exemplo, "etiológico". Ao ficar-se diante de uma hipótese, se está diante de algo ainda não revelado, mas tal hipótese ao tentar explicar os caracteres do "algo" não revelado remete justamente ao uso de um Método, fundado este nos preceitos acima referidos. Finalmente, se é, concomitantemente, remetido à "interpretação" deste algo e interpretar é buscar-se um sentido, uma explicação, é necessário que este sentido e esta explicação surjam e possam ser demonstradas e isso só será possível quando o evento é observado e depois refletido num outro patamar, inserido nos sistemas dos quais sua inteligência, sua Razão dispõe, ou seja, seu conhecimento. O observador (leia-se aqui, o médico-legista) só pode, a nosso ver e como já dissemos, interpretar o fenômeno por intermédio de um método dialético e deve ainda, fugir das armadilhas internas das "emoções", das "crenças", ou, dos "ídola", como dizia Francis Bacon, dos "costumes", dos "hábitos" que dificultam a plasticidade das atividades superiores do encéfalo humano. Ainda dentro de este interpretar, o médico-legista de forma metódica deve estar atento às simulações, tanto àquelas inconscientes, fruto da ausência de um préconhecimento, ou pré-compreensão de experiências definidas e vividas (atente-se aqui ao significado de "vivência" na ótica de Garcia Morente), ou de definidas práticas (leia-se aqui saberes técnicos no dizer de Granger), quanto daquelas provocadas na ambiência externa de forma intencional, quando o agente criminal busca esconder e dissimular o crime, pois, nestas situações, o interpretar falha, fracassa e, parte substancial do agir metódico fica sumariamente prejudicada. 
O método dialético pode ser utilizado (fuja-se aqui do "utilitarismo") na forma linear, seqüencial, onde teses e antíteses se sucedem em sínteses e novas teses (...) indefinidamente até que o Entendimento humano pela faculdade do juízo determinante (no sentido kantiano do termo) estabeleça que se tenha chegado à essência do algo procurado. Nesta visão linear, ou ainda, tendo-se como fundo de quadro um segmento de reta, o sentido seria unilateral ou bilateral se a grandeza envolvida fosse o espaço, enquanto intuição externa kantiana. Se o "uso" deste método tiver como fundo de quadro um círculo, é bom que fique claro desde o início que não se está aqui buscando uma hermenêutica do método, temos o objetivo de ampliar o raio de ação do conhecimento do mesmo método para se entender no sentido prático do agir pericial o seu uso, portanto, se a figura geométrica que se vai usar agora, é o círculo, temos a considerar que: a interpretação do evento, caso, fenômeno, repousa sobre a possibilidade de uma circulação, em que se vai de uma interpretação à outra, onde a interpretação $\boldsymbol{a}$ que sucede $\boldsymbol{b}$ depende de elementos da antecedente e ainda de uma terceira que explique esta relação entre o antecedente e a conseqüente. Esta proposta, no entanto, pode remeter o Entendimento a uma situação tautológica, onde a interpretação $\boldsymbol{a}$ que sucede $\boldsymbol{b}$ não muda necessariamente a antecedente, obstaculizando-se o método enquanto processo evolutivo. Porém, existe a possibilidade de em vez de restringir-se a interpretação a este círculo que se poderia chamar de vicioso, ter-se como contrapartida um "círculo virtuoso" em forma de espiral, como propôs Piaget, onde o interpretar, que etimologicamente significa: explicar, traduzir, compreender, avaliar, dar-se-á num sentido evolutivo, não se permitindo um retorno conceitual, mas ao contrário, um retorno à empiria com sistemas conceituais evoluídos e assim utilizar-se o método dialético, porém sem a limitação restrita ao "ir e vir", enquanto movimento do Entendimento humano. 


\section{CONCLUSÕES E CONSIDERAÇÕES}

Após o périplo sobre a Bibliografia pesquisada, as considerações sobre a Doutrina, a Pesquisa em documentos médico-legais, a reflexão e proposta de um Método nesta Tese, onde se pôde perceber a amplitude temática da Medicina Legal, pois, desde Paolo Zacchia, no Século XVII, o universo desta ciência já comportava temas tão diversos como: jejum e abstinência, lesão corporal, Direito Médico, gravidez, etc. chegando-se aos dias atuais onde o universo temático só ampliou, pode-se estabelecer que a Medicina Legal, é uma ciência Bio-

\section{Psico-Social.}

Os fundamentos biológicos desta ciência são do entendimento comum. Autores como Flamínio Fávero, por exemplo, afirmam que a Medicina Legal é "Medicina Aplicada", ora, em sendo Medicina é a Medicina Legal por conseqüência advinda dos conhecimentos da Biologia. Além de muitas outras, as referências biológicas que permeiam todo o conteúdo desta ciência. Vejamos, à guisa de exemplo, os estudos de Megnin que introduziram nos saberes científicos (aqui sob a ótica de Granger) da Medicina Legal a possibilidade de se estabelecer o tempo de morte (cronotanatognose) a partir da digestão larvária e dos diversos tipos da fauna cadavérica. Ou ainda, o diagnóstico da identificação da paternidade e da maternidade como objeto da inquietação médico-legal, concomitantemente aos trabalhos de Landsteiner e Wiener sobre os tipos sanguíneos, sucedidos estes, cientificamente, pela referida identificação através de metodologia genética, ou seja, através do DNA. Os exemplos suceder-se-iam ininterruptamente, o que só confirmaria o fundamento biológico da Medicina Legal. 
O atributo Psicológico desta ciência é inerente à díade fenômeno/observador, ou melhor ainda, evento/médico-legista. O fenômeno é a unidade elementar da consciência (na ótica kantiana), percebido e apercebido pela capacidade neural do encéfalo humano de entender, imaginar, sentir, perceber suas nuances. Portanto, uma "leitura da experiência" no sentido piagetiano do conceito. É também o pensar algo, pensar o fenômeno como elemento da tomada de consciência do mesmo, chegar-se ao conceito kantiano de "unidade originariamente sintética da apercepção", portanto, apercepção fenomênica.

A perfeita conjunção (no sentido Lógico do termo) entre o fenômeno (evento observado), e o observador (médico-legista) pode mudar processos neurais, portanto, mudar a percepção e a apercepção enquanto capacidade perscrutadora, organizadora, avaliadora do encéfalo humano, gerando por atividade estruturante (estrutura no sentido piagetiano do termo) e dialética, novo processo perceptivo e aperceptivo que se repetirá até que se estabeleça a essência, a substância do evento, do fenômeno e se atinja assim, o desiderato pericial, ou seja, a prova científica. Este périplo pelas estruturas encefálicas é exemplo evidente do elemento psicológico na Medicina Legal, em uma ótica interna. Outra ótica existe, e têm caráter externo, evidenciada pelas manifestações emotivas presentes na maior parte dos eventos médico-legais, onde estes, oriundos da violência, geram sofrimentos pessoais nas vítimas, nos seus parentes, no entorno social. Em outras ocasiões, as pressões psicológicas e sociais atingem o perito, como aquelas dos eventos em que há comoção pública e onde seu equilíbrio emocional é essencial ao desiderato do seu ofício, sob pena de se chegar a resultados não condizentes com a excelência que deve permear o trabalho pericial. Além de tudo e principalmente, existe um amplo leque de temas que é estudado pela Psicologia e Psiquiatria médico-legais, disciplinas estas de fundamental interesse para a Medicina Legal.

O caráter Social da Medicina Legal é reconhecido pela maioria dos autores, entre estes, Genival Veloso de França que entende esta ciência da seguinte forma (2008: 1): “A Medicina Legal é uma ciência de largas proporções e de extraordinária importância no conjunto dos interesses da coletividade, porque ela existe e se exercita cada vez mais em razão das necessidades da ordem pública e do equilíbrio social”.

A Medicina Legal é para nós, sem dúvida, uma Ciência Bio-Psico-Social - Ciência aplicada no dizer de Fávero (1991) ou ciência e arte na ótica de França (2008), como já citado no capítulo sobre a Doutrina, nesta Tese? Os saberes necessários ao desempenho do médico- 
legista são técnicos ou científicos sob a ótica de Granger e já considerados no mesmo capítulo citado? Estas reflexões, extensivamente feitas neste texto sobre a Doutrina, permitem-nos afirmar com toda convicção (aqui sob a ótica kantiana) que a Medicina Legal é ciência, de acordo com os cânones da Filosofia da Ciência. Não a ciência do universal e do necessário das ciências exatas, tanto na visão aristotélica e kantiana como no entender popperiano que acrescenta a estes atributos a possibilidade de falseamento, nem também a ciência do individual, onde não se faz ciência sob a ótica de Granger e muito menos a ciência do acidental onde Aristóteles entende não haver ciência pela contingência ali presente. A Medicina Legal é ciência no sentido da classe definida por Granger como sob a ótica do freqüente aristotélico (hòs epì tò polú - $\omega \sigma \varepsilon \pi \mathrm{\tau} \tau \mathrm{o} \pi \mathrm{o} \lambda v$ ), termo cunhado por Porchat Pereira. Com estes dois atributos essenciais classe e "freqüente aristotélico", onde o necessário está presente e não o contingente ou o acidental; necessário este, que não é de menor importância em comparação com o necessário matemático, pois como vimos o necessário não tem gradação, ele simplesmente é. A Medicina Legal é definida como ciência dentro dos rigores da Filosofia da Ciência, assim já o demonstramos. Em sendo ciência, ela tem a necessidade de um Método, que seja uma via, caminho para o Entendimento explicar os fatos, em suma, aquilo que ocorre. Propusemos então, um Método que é um Método Dialético, baseado em Piaget e Kant e que contempla: conteúdo e forma das proposições sobre os fenômenos que são simultâneos, sendo o primeiro determinável e a segunda determinante; contempla também o contrário, ou seja, a hipótese rival; busca a síntese demonstrativa que supera as aporias e especialmente a não contradição das proposições.

A Medicina Legal amparada nos pressupostos da Filosofia da Ciência, orientada pelo Método Dialético proposto é sem dúvida uma ciência Bio-Psico-Social. 


\section{REFERÊNCIAS BIBLIOGRÁFICAS}

ACHAVAL, Alfredo. Manual de Medicina Legal. Buenos Aires- Argentina: AbeledoPerrot, 1962.

ARANGO, Héctor Gustavo. Bioestatística. Rio de Janeiro: Guanabara Koogan, 2005.

ARBENZ, Guilherme Oswaldo. Medicina Legal e Antropologia Forense. São Paulo: Livraria Atheneu, 1988.

ARISTÓTELES. Metafísica. Edición Trilingüe. Trad. Valentin Garcia Yebra. Madrid: Editorial Gredos, 1998.

BACHELARD, Gaston. L'activité rationaliste de la physique contemporaine. Paris: PUF, 1951.

BELL, E. T. The Development of Mathematics. Califórnia Institute of Technology, 1945.

BERTI, Enrico. As razões de Aristóteles. Tradução de Dion Davi Macedo. São Paulo:

Edições Loyola, 1998.

BENTHAM, Jeremias. Tratado de las Pruebas Judiciales. Buenos Aires: Ediciones Jurídicas Europa-América, 1971.

BERGERON, Henri. Médecine Légale et Jurisprudence Médicale. Paris-França: A. Maloine Éditeur, 1898.

BERLINSKI, David. O advento do Algoritmo. Trad. de Leila Ferreira de Souza Mendes. São Paulo-SP: Editora Globo S. A., 2002.

BRITO, Joaquim Marcelino. Tratado Elementar de Medicina Legal. Rio de Janeiro-RJ.: Typographia da Escola de Serafim José Alves - Editor, 1883.

BONNET, Emilio Federico Pablo. Medicina Legal. Buenos Aires: Lopez Libreros Editores S.R.L., 1967.

BROUARDEL, Paul. Les Asphyxies- par le gaz, les vapeurs et les anesthésiques. ParisFrança: Librairie J.B. Baillière, 1896.

. L'infanticide. Paris-França: Librairie Baillière et Fills, 1897.

CAMPS, Francis E.. Legal Medicine. Bristol-England: John Wright \& Sons Ltd., 1968.

Del NERO, Henrique Schützer. O Sítio da Mente: pensamento, emoção e vontade no cérebro humano. São Paulo: Collegium Cognitio, 2002.

DÉROBERT, L.. Médecine Légale. Paris-França: Flammarion Médecine-Sciences, 1974.

DESCARTES, René. Discurso do Método-Regras para a direção do Espírito. Trad. de Pietro Nassetti. São Paulo-SP: Editora Martin Claret, 2003. 
Princípios de Filosofia. Trad. de Ana Cotrim e Heloisa da Graça Burati. São Paulo - SP.: Editora Rideel, 2007.

. Meditações Metafísicas. Trad. de Maria Ermantina Galvão e Homero Santiago. São Paulo, SP: Livraria Martins Fontes Editora Ltda, 2005.

DÖHRING, Erich. La investigacion del estado de los hechos en el processo-La prueba su practica y apreciacion. Buenos Aires: Ediciones Jurídicas Europa-America, 1972.

DAMBRE, A. Traité de Médecine Légale et de Jurisprudence de la Médecine. Paris, França: V. Adrien Delahaye et Cie. Libraires-Editeurs, 1878.

DEVERGIE, A. Médecine Légale. Bruxelles: H. Dumont Libraire-Éditeur, 1837.

FÁVERO, Flamínio. Medicina Legal. Belo Horizonte: Editora Vila Rica, 1991.

FRANÇA, Genival Veloso. Medicina Legal. Rio de Janeiro: Editora Guanabara, 2004.

. Medicina Legal. Rio de Janeiro-RJ.: Editora Guanabara, 2008.

GANDOLFI, Giovanni. Fondamenti di Medicina Forense Analitica. Milano-Italia: Pressogli Editori, 1862.

GARCIA, Agnaldo. Cognição e Evolução: a contribuição de Konrad Lorenz. Ciências \& Cognição; Ano 02, Vol 04, mar/2005. Disponível em WWW.cienciasecognicão.org

GARCÍA MORENTE, Manuel. Fundamentos de Filosofia. São Paulo: Editora Mestre Jou, 1980.

GISBERT Calabuig, J.A.. Medicina Legal y Practica Forense. Valencia-Espanha: Editorial Saber, 1958.

GOMES, Hélio. Medicina Legal. Rio de Janeiro: Biblioteca Universitária Freitas Bastos, 1968.

GORPHE, François. De la Apreciacion de las Pruebas. Buenos Aires: Ediciones Jurídicas Europa-América, 1955.

GRANGER, Gilles Gaston. A Ciência e as Ciências. Trad. de Roberto Leal Ferreira. São Paulo: Editora Unesp, 1994.

Pensée Formelle et Sciences de L'Homme. Paris: Éditions Montaigne, 1960.

Filosofia do Estilo. Trad. de Scarlett Zerbetto Marton. São Paulo: Editora da Universidade de São Paulo, 1974.

La Vérification. Paris: Éditions Odile Jacob, 1992.

HOFMANN, E. Nouveuax Éléments de Médecine Légale. Paris-França: Librairie J.B. Bailliere et Fills, 1881.

HOUAISS, António. Dicionário da Língua Portuguesa. Rio de Janeiro: Editora Objetiva Ltda., 2001.

KANT, Immanuel. Crítica da Razão Pura. Trad. de Manuela Pinto dos Santos e Alexandre Fradique Morujão. Lisboa-Portugal: Fundação Calouste Gulbenkian, 1994.

Crítica da Faculdade do Juízo. Trad. de Valerio Rohden e António Marques. 2a Ed.. Rio de Janeiro: Forense Universitária, 2008. 
Escritos pré-críticos. Trad. de Jair Barboza, Joãosinho Beckenkamp, Luciano Codato, Paulo Licht dos Santos e Vinicius Figueiredo. São Paulo: Editora UNESP., 2005.

LACASSAGNE, A. Précis de Médecine Judiciaire. Paris-França: Masson Editeur, 1878.

Il Vade-Mecum del Medico Perito. Milano-Italia: Dottor Francesco Vallardi Casa Editrice, 1880.

LALANDE, André. Vocabulário Técnico e Crítico da Filosofia. Trad. de Fátima Sá Correia, Maria Emília V. Aguiar, José Eduardo Torres e Maria Gorete de Souza. São Paulo: Martins Fontes, 1999.

LEGRAND, Du Saulle. La Folie devant les Tribunaux. Paris: Librairie F. Savy, 1864.

LOPEZ, Leopoldo. Tecnica Medico Legal. Valencia-Espanha: Editorial Saber, 1953.

LORENZ, Konrad. L'Envers du Mirroir, Une Histoire Naturelle de la Connaissance. Paris: Flammarion, 1975.

MAFFEI, Walter Edgard. Os Fundamentos da Medicina. São Paulo: Livraria Editora Artes Médicas Ltda., 1978.

MAlatestA, Nicola Framarino Dei. A Lógica das Provas em Matéria Criminal. Trad. de Alexandre Augusto Correia. São Paulo: Editora Saraiva, 1960.

MASCHKA, G. Trattato di Medicina Legale. Napoli-Italia: Unione Tipografico Editrice, 1889.

MATA, Pedro da. Tratado de Medicina y Cirugia Legal. Madrid-Espanha: Libreria Extranjera y Nacional, Cientifica y Literaria, 1874.

MAYR, Ernst. Isto é Biologia: a ciência do mundo vivo. Trad. Claudio Angelo. São Paulo: Companhia das Letras, 2008.

MENDES, Erasmo G. Fisiologia: crises? In: Estud. av. [on line]. 1994, v.8, n.20[cited 200902-23], pp. 83-97. Disponível em: www.scielo.br/scielo.php

MITTERMAIER, C.J.A. Tratado da Prova em Matéria Criminal. Trad. de Herbert Wüntzel Heinrich. Campinas-SP: Editora Bookseller Ltda, 1996.

NAGEL, Ernest. A prova de Gödel. Trad. Gita k. Guinsburg. São Paulo: Editora Perspectiva S. A., 2003.

NEVES e CASTRO, Francisco Augusto das. Teoria das Provas e suas aplicações nos atos civis. Campinas-SP: Servanda Editora, 2000.

NINA RODRIGUES, Raymundo. A Medicina Legal no Brasil. Salvador-Ba.: Typographia Bahiana de Cincinato Melchiades, 1905.

ORFILA, M. Leçons de Médecine Légale - De L'Empoisonnement. Paris: Béchet Jeune, 1823.

PEIXOTO, Afrânio. Medicina Legal. Rio de Janeiro-RJ.: Francisco Alves Editora, 1918.

PEREIRA, Oswaldo Porchat. Ciência e Dialética em Aristóteles. São Paulo: Editora Unesp, 2001.

PIAGET, Jean. O Estruturalismo. Trad. de Moacir Renato de Amorim. Rio de Janeiro-RJ: Editora Bertrand Brasil LTDA, 2003. 
Epistemologia Genética. Trad. de Álvaro Cabral. São Paulo-SP: Livraria Martins Fontes Editora LTDA, 1990.

. Biologia e Conhecimento. Trad. de Francisco M. Guimarães. Petrópolis-RJ.: Editora Vozes Ltda, 1996.

PIAGET, Jean et allii. La Lecture de L'Expérience. (Études D’Épistémologie Génétique, V), Paris: PUF., 1958.

PIAGET, Jean e INHELDER, Barbel. L'image mentale chez l'enfant. Paris: P.U.F., 1966.

Les liaisons analytiques et synthétiques. Paris; P.U.F., 1957.

PIÉDELIÉVRE, René. Médecine Légale. Paris-França: J.B. Bailliere et Fils Editeurs, 1963.

PIGA, Antonio. Medicina Legal de Urgência. Madrid-Espanha: Ediciones Mercurio, 1928.

PONSOLD, Albert. Manual de Medicina Legal. Barcelona-Espanha: Editorial Científico Médica, 1955.

POPPER, Karl Raimund. A Lógica da Pesquisa Científica. Trad. de Leônidas Hegenberg e Octanny Silveira da Mota. São Paulo: Editora Cultrix, 1972. 1996.

O Mito do Contexto. Trad. de Paula Taipas. Lisboa-Portugal: Edições 70 Ltda.,

PURVES, Dale...(et.al.). Neurociências. Trad. Carla Dalmaz... (et.al.). $2^{\mathrm{a}}$ Ed. Porto Alegre: Artmed, 2005.

RAMOZZI-CHIAROTTINO, Zélia. Psicologia e Epistemologia Genética de Jean Piaget. São Paulo: Editora Pedagógica Universitária, 1988. 1972.

Piaget: Modelo e Estrutura. Rio de Janeiro-RJ: Livraria José Olympio Editora,

Em Busca do Sentido da Obra de Jean Piaget. São Paulo: Editora Ática, 1994.

ROJAS, Nerio. Medicina Legal. Buenos Aires-Argentina: Libreria y editorial "El Ateneo", 1936.

RAWLS, John. Uma Teoria da Justiça. Trad. Almiro Pisetta e Lenita M. R. Esteves. São Paulo-SP.: Livraria Martins Fontes Editora Ltda., 1997.

SÁNCHEZ, José Maria. Medicina Legal. Buenos Aires-Argentina: Casa Editorial Sebastián Amorrotu, 1924.

SANTOS, Moacyr Amaral. Prova Judiciária no Cível e Comercial. São Paulo: Max Limonad Editora de Livros de Direito, 1970.

SEDILlOT, C. Manual Completo de Medicina Legal. Trad. Antonio José de Lima Leitão. Lisboa-Portugal: Typografia Panorama, 1855.

SIMAS ALVES, Ernani. Medicina Legal e Deontologia. Curitiba-PR.: Editora Universidade do Paraná, 1965.

SIMONIN, C. Medicina Legal Judicial. Barcelona-Espanha: Editorial Jims, 1962.

SOUZA, José Soriano. Ensaio de Medicina Legal. Recife-Pernambuco: Livraria Acadêmica, 1870. 
SOUZA LIMA, Agostinho José. Tratado de Medicina Legal. Rio de Janeiro-RJ.: Typographia Hildebrant, 1904.

TOURDES, Gabriel. Traité de Médecine Légale. Paris-França: Asselin et Nouveau Éditeurs, 1896.

ZACCHIA, Paolo. Quaestiones medico-legales. Amsterdã: Tipografia J.Blaeu, 1651. 